DANIEL MIRANDA DOS SANTOS

COMPORTAMENTO ESTRUTURAL DE PONTES COM PROTENSÃO NO EXTRADORSO

São Paulo

2006 
DANIEL MIRANDA DOS SANTOS

\section{COMPORTAMENTO ESTRUTURAL DE PONTES COM PROTENSÃO NO EXTRADORSO}

Dissertação apresentada à Escola

Politécnica da Universidade de

São Paulo para obtenção do título

de mestre em engenharia.

Área de Concentração:

Engenharia de Estruturas

Orientador:

Fernando Rebouças Stucchi

São Paulo

2006 
Este exemplar foi revisado e alterado em relação à versão original, sob responsabilidade única do autor e com a anuência de seu orientador.

São Paulo, 07 de agosto de 2006.

Assinatura do autor

Assinatura do orientador

FICHA CATALOGRÁFICA

Santos, Daniel Miranda dos

Comportamento estrutural de pontes com protensão no extradorso / D.M. dos Santos. -- São Paulo, 2006.

$132 \mathrm{p}$.

Dissertação (Mestrado) - Escola Politécnica da Universidade de São Paulo. Departamento de Engenharia de Estruturas e Fundações.

1.Pontes 2.Concepção estrutural 3.Protensão extradorsal 4.Estudo paramétrico I.Universidade de São Paulo. Escola Politécnica. Departamento de Engenharia de Estruturas e Fundações Il.t. 
À minha mãe, exemplo de vida, e à minha noiva, meu porto seguro, pelo apoio inestimável. 


\section{AGRADECIMENTOS}

Ao prof. Fernando Rebouças Stucchi, pela excelente orientação, pela confiança e amizade demonstrada na elaboração deste trabalho.

Aos professores Ricardo França e Hideki Ishitani, pelo estímulo e contribuições dadas no exame de qualificação.

Aos professores, colegas e funcionários do departamento de estruturas e fundações, pelo apoio e amizade nestes anos de convívio.

Aos amigos Augusto e Rute, por tornarem a nossa adaptação em São Paulo mais agradável, pelo conforto nos momentos difíceis e pela alegria compartilhada em todas as conquistas destes últimos anos.

À CAPES, pela bolsa de mestrado concedida.

À minha mãe, Célia Regina, pelo apoio, pelo amor incondicional por seus filhos e pelas lições de vida que sempre levarei comigo.

Aos meus irmãos, André e Julie, meu pai, Jorge Modesto e meus sobrinhos, Luisa e Lucas, pelo carinho e confiança.

À minha sogra, Cátia Moreira, pelo incentivo e amor dispensados como a um filho.

À minha noiva, Priscila Soeiro Moreira, pelo amor incondicional e pela confiança na construção de um futuro melhor. 


\section{RESUMO}

Nos últimos anos, a protensão externa aplicada a estruturas de pontes tem evoluído de forma excepcional, o que permite maior liberdade de projeto e, consequentemente, possibilita o surgimento de novas tipologias estruturais.

Um exemplo desse desenvolvimento é a ponte com protensão no extradorso, que começa a se difundir no meio técnico como uma transição econômica entre as pontes de concreto protendido e as estaiadas. A idéia, atribuída ao engenheiro francês Jacques Mathivat, consiste em utilizar protensão externa sobre os apoios intermediários, com o auxílio de pequenas torres.

Neste trabalho é apresentada uma revisão bibliográfica ampla sobre os diversos tipos de pontes com emprego de protensão, visando focar nos aspectos importantes e que auxiliam no entendimento do comportamento estrutural das pontes com protensão no extradorso. É realizado, também, um estudo da flutuação de tensão nos cabos de protensão, com vistas à fadiga dos mesmos, que é um fator de extrema importância.

Além disso, é realizado um vasto estudo paramétrico de diversos tipos de modelos estruturais, que têm por objetivo um aprofundamento da compreensão do comportamento estrutural das pontes com protensão no extradorso, sendo que, a partir da análise dos resultados obtidos, foram sugeridos alguns critérios de projeto. 


\section{ABSTRACT}

In recent years, external prestressing applied to structures of bridges has experienced exceptional development, permitting a greater freedom in design and, consequently, the appearance of new structural typologies.

An exemple of such development is the extradosed bridge, a concept that begins to spread in technical media as a low cost transition between prestressed concrete bridges and cable-stayed bridges. The idea, which should be attributed to French engineer Jacques Mathivat, consists of using external prestressing at intermediate supports, with the help of small towers.

In this work, a comprehensive review of the literature about different types of bridges using prestressing is presented, aiming at the important aspects that help us understand the structural behavior of extradosed bridges. A study of stress fluctuation in prestressing cables is also presented, having in mind fatigue, an extremely important factor.

Besides, an ample parametric study of different types of structural arrangements is performed, with the purpose of having a deeper understanding of the structural behavior of extradosed bridges. Analysis of the results led to suggesting some desing criteria. 


\section{SUMÁRIO}

LISTA DE FIGURAS _ $i$

LISTA DE TABELAS _

LISTA DE SÍMBOLOS__ ix

1 INTRODUÇÃO 1

1.1. GENERALIDADES E JUSTIFICATIVAS _ 1

1.2. OBJETIVOS 3

1.3. APRESENTAÇÃO DO TRABALHO _ 3

2 REVISÃO BIBLIOGRÁFICA__ 5

2.1. GENERALIDADES__ 5

2.2. PONTES DE CONCRETO PROTENDIDO __ 8

2.2.1. Protensão interna aderente____ 9

2.2.2. Protensão interna não aderente ___ 11

2.2.3. Protensão externa____ 12

2.2.4. Construção de pontes de concreto pelo método dos balanços sucessivos ___ 14

2.3. PONTES ESTAIADAS —_ 16

2.3.1. Breve histórico __ 16

2.3.2. Análise da evolução das pontes estaiadas e suas características __ 19

2.3.3. Configuração do sistema de cabo __ 20

2.3.3.1. Sistema longitudinal dos cabos ___ 21

2.3.3.2. Sistema transversal dos cabos __ 22

2.3.3.3. Sistema de cabos em múltiplos vãos ___ 24

2.4. PONTES SUPORTADAS POR CABOS PROTENDIDOS INFERIORES 26

2.5. PONTES COM PROTENSÃO NO EXTRADORSO _ 28

2.5.1. Ponte Odawara Blueway __ 30

2.5.2. Ponte Tsukuhara___ 31

2.5.3. Ponte Second Mandaue - Mactan __ 32

2.5.4. Pontes Kiso River e Ibi River ___ 33

2.5.5. Terceira ponte sobre o Rio Acre ___ 33 
2.5.6. Ponte da integração Brasil-Peru

2.5.7. Pontes construídas com algumas características do sistema de protensão no extradorso

2.5.8. Conclusões sobre as pontes com protensão no extradorso construídas 35

2.6. COMPORTAMENTO À FADIGA DE CABOS PÓS-TRACIONADOS _ 37

2.6.1. Generalidades. __ 37

2.6.2. Ensaios de resistência à fadiga e curvas Wöhler. __ 38

2.6.3. Fadiga por fricção ("fretting fatigue") ___ 41

2.6.4. Resistência à fadiga condicionada pelas ancoragens ___ 43

2.6.4.1. Tensões locais __ 43

2.6.4.2. Tensões de flexão___ 44

2.6.5. Resistência à fadiga de sistemas de protensão com pós - tração ___ 45

3 ESTUDO PARAMÉTRICO__ 50

3.1. INTRODUÇÃO —

3.2. MÉTODO DE ANÁLISE___

3.3. PARÂMETROS ADOTADOS _

3.3.1. Propriedades físicas dos materiais___ 52

3.3.2. Modelo básico _ـ 52

3.4. PARÂMETROS ANALISADOS_

3.4.1. Altura da torre e do tabuleiro___ 55

3.4.2. Nível de tensão dos cabos no extradorso___ 56

3.4.3. Grau de compensação das cargas permanentes__ 56

3.4.4. Vão lateral _ـ 57

3.4.5. Altura variável do tabuleiro___ 57

3.4.6. Modelos considerados _ 59

3.5. AÇÕES E HIPOTESES DE CARREGAMENTOS _ 59

3.5.1. Peso próprio _ 59

3.5.2. Revestimento e guarda rodas___ 60

3.5.3. Carga variável _ 60

3.6. DESCRIÇÃO DO PROCESSO DE ANÁLISE __ 61

3.6.1. Cálculo da protensão dos cabos no extradorso (modelo básico) ___ 62

3.6.2. Determinação da área de aço extradorsal (modelo básico)____ 66

4 RESULTADOS DO ESTUDO PARAMÉTRICO _ 68

4.1. CONSIDERAÇÕES INICIAIS ___ 68 
4.2. RESULTADOS DO PROCESSAMENTO DO MODELO BÁSICO 68

4.3. COMPORTAMENTO ESTRUTURAL AO VARIAR A ALTURA DA TORRE E A DO TABULEIRO _ 72

4.3.1. Influência sobre a protensão média, área de aço extradorsal e variação da flutuação de tensão nos cabos 72

4.3.2. Influência sobre as solicitações normais e as flechas imediatas no tabuleiro 75

4.4. COMPORTAMENTO ESTRUTURAL AO MODIFICAR O NÍVEL DE TENSÃO DOS CABOS NO EXTRADORSO

81

4.4.1. Influência sobre a área de aço extradorsal e variação da flutuação de tensão nos cabos_ 81

4.4.2. Influência sobre as solicitações normais e as flechas imediatas no tabuleiro 82

4.5. COMPORTAMENTO ESTRUTURAL AO MODIFICAR O NÍVEL DE COMPENSAÇÃO DE CARGAS PERMANENTES 84

4.6. ANÁliSE DA PROPORÇÃO ENTRE O VÃO LATERAL E O VÃO CENTRAL 87

4.6.1. Influência sobre a área de aço extradorsal e variação da flutuação de tensão nos cabos _

4.4.3. Influência sobre os diagramas de momento fletor, de esforço normal e sobre as flechas imediatas. 89

4.7. RESULTADO DO PROCESSAMENTO DO MODELO 10 (h VARIÁVEL) 93

4.8. COMPORTAMENTO ESTRUTURAL FRENTE À PROTENSÃO INTERNA OU EXTERNA CONVENCIONAL 94

4.8.1. Comportamento estrutural do modelo básico frente à protensão de pequena excentricidade 96

4.8.2. Comportamento estrutural do modelo com $80 \%$ de compensação das cargas permanentes frente à protensão de pequena excentricidade 106

4.9. VERIFICAÇÃO DA SEGURANÇA DOS CABOS NO EXTRADORSO DO MODELO BÁSICO AO ESTADO LIMITE ÚLTIMO 113

4.10. MODELOS 5a e 5c COMPARADOS À VIGA CONTÍNUA 115

4.11. ALGUMAS CONSIDERAÇÕES SOBRE O CÁLCULO DA PROTENSÃO INTERNA E EXTRADORSAL CONDICIONADA AO MÉTODO CONSTRUTIVO 
5 CONCLUSÕES E SUGESTÕES

5.1. CONCLUSÕES 121

5.2. SUGESTÕES PARA CRITÉRIOS DE PROJETO 125

5.3. SUGESTÕES PARA TRABALHOS FUTUROS 126 REFER $\hat{E} N C I A S$ BIBLIOGRÁFICAS 128 BIBLIOGRAFIA COMPLEMENTAR 131 ANEXO I: PROTENSÃo, ÁREA, PESO E TENSÕES dos CABOS NO EXTRADORSO DOS 21 MODELOS ANALISADOS

ANEXO II: MOMENTOS FLETORES NO TABULEIRO AO VARIAR A SUA ALTURA E A DA TORRE

ANEXO III: ALGUNS MODELOS COM ALTURA DE TABULEIRO VARIÁVEL 


\section{LISTA DE FIGURAS}

Figura 1.1 - Ponte Odawara Blueway, Japão (1994). ................................................1

Figura 2.1 - Ponte Ganter, Suíça (1980). ...........................................................

Figura 2.2 - Sistemas de cabos protendidos de pequena excentricidade, (a) moderada excentricidade (b) e grande excentricidade (c) ...............................................

Figura 2.3 - Exemplos de traçado de cabos para vigas de dois vãos, (a) protensão interna e (b) combinação da protensão interna com a extradorsal. ..........................10

Figura 2.4 - Ponte sobre o rio Deba, Espanha (2004)..........................................11

Figura 2.5 - Ponte Long Key - Disposição da protensão externa. ............................12

Figura 2.6 - Ponte Arbois (França, 1985).............................................................14

Figura 2.7 - Construção por balanços sucessivos (ponte em viga), (a) tramo inicial, (b) fase intermediária e (c) fechamento do vão................................................... 14

Figura 2.8 - Ponte projetada por Löscher, Alemanha em 1784 (POLDONY;

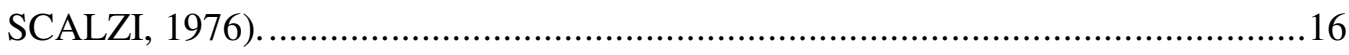

Figura 2.9 - Ponte estaiada de concreto armado sobre o canal Donzère (vão central de 81 m, 1952) na França. Foto: Nicolas Janberg (www.structurae.net)...................18

Figura 2.10 - Ponte da Normandia, França (1994). ...............................................19

Figura 2.11 - Sistema-auto ancorado (a) e externamente ancorado (b). ..................20

Figura 2.12 - Disposição longitudinal dos cabos: (a) leque, (b) harpa e (c) semi-

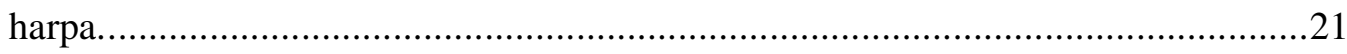

Figura 2.13 - Exemplos de seção transversal para a suspensão central: (a) seção unicelular e (b) seção bicelular......................................................................23

Figura 2.14 - Equilíbrio do momento torsor, provocado pela força $\mathrm{P}$, através de suspensão lateral em tabuleiro com rigidez a torção desprezível (GIMSING, 1983).

Figura 2.15 - Comportamento estrutural de uma ponte estaiada com três vãos

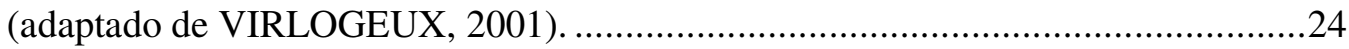

Figura 2.16 - Deformação de pontes estaiadas com múltiplos vãos para carregamentos assimétricos (adaptado de VIRLOGEUX, 2001)...........................25

Figura 2.17 - Soluções possíveis para pontes com cabos em múltiplos vãos (adaptado

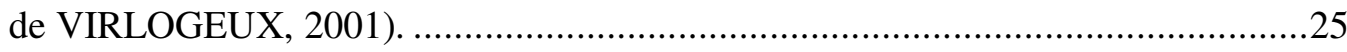


Figura 2.18 - Esquema da ponte Obere Argen na Argentina, 1989 (CAZET, 1990).27

Figura 2.19 - Ponte The Truc De La Fare, França (VIRLOGEUX et al. 1994)........27

Figura 2.20 - Ponte Osormort na Espanha (1995). ................................................28

Figura 2.21 - Ponte Odawara Blueway, Japão (1994). .............................................30

Figura 2.22 - Ponte Tsukuhara, Japão (1998)....................................................... 31

Figura 2.23 - Ponte Second Mandaue - Mactan, Filipinas (1999). ..........................32

Figura 2.24 - Ponte Kiso River, Japão (2001).......................................................33

Figura 2.25 - Terceira ponte sobre o Rio Acre, Brasil (2006)..................................34

Figura 2.26 - Ponte da integração Brasil - Peru, Brasil (2006)...............................35

Figura 2.27 - Ponte Sunninberg, Suíça (1998). .....................................................36

Figura 2.28 - Variação de tensão axial durante ensaio de fadiga. ............................38

Figura 2.29 - Exemplo de curva Wöhler para cordoalhas de aço protendido. ...........39

Figura 2.30 - Diagrama de Goodman para armaduras passivas. ............................40

Figura 2.31 - Condições favoráveis aos danos de fadiga por fricção, (a) protensão aderente e (b) protensão externa.................................................................... 41

Figura 2.32 - Aceleração do processo da fadiga e fadiga por fricção nas ancoragens.

Figura 2.33 - Variação da rotação entre o cabo e o tabuleiro produzida por carregamento variável (adaptado de VIRLOGEUX, 1994). .44

Figura 2.34 - Exemplo de sistema de ancoragem em estais (adaptado de FIB, 2005).

.

Figura 3.1 - Seções transversais do tabuleiro e da torre do modelo básico................53

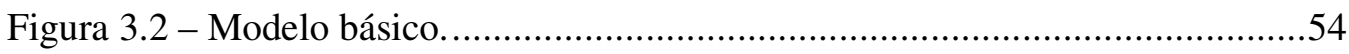

Figura 3.3 - Características geométricas adotadas para o estudo do vão lateral........57

Figura 3.4 - Modelo com tabuleiro variável (modelo 10) ....................................58

Figura 3.5 - Seções transversais adotadas no modelo que possui tabuleiro com seção

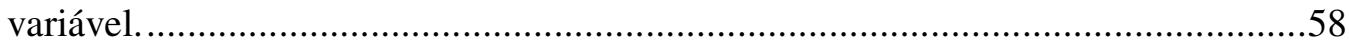

Figura 3.6 - Casos adotados de carregamento variável......................................61

Figura 3.7 - Procedimento de cálculo da protensão em cada cabo. .........................62

Figura 3.8 - Esquema estrutural da etapa 1. ..................................................63

Figura 3.9 - Esquema estrutural da etapa 1 considerando a simetria......................63

Figura 3.10 - Esquema estrutural da etapa 2 considerando a simetria....................64 
Figura 3.11 - Esquema estrutural da etapa 3 considerando a simetria....................64

Figura 3.12 - Esquema estrutural da etapa j considerando a simetria......................65

Figura 3.13 - Numeração genérica dos cabos no extradorso.................................66

Figura 4.1 - Vista longitudinal do modelo básico (modelo 5a da tabela 3.3)............68

Figura 4.2 - Configuração original e deformada (ampliada 100 vezes) para o modelo básico, submetido ao carregamento permanente. .................................................70

Figura 4.3 - Configuração original e deformada (ampliada 100 vezes) para o modelo básico, submetido ao carregamento 5 da figura 3.6............................................71

Figura 4.4 - Diagrama de momento fletor no tabuleiro devido ao carregamento permanente e envoltória de momento fletor (modelo básico)...............................71

Figura 4.5 - Diagrama de esforço normal no tabuleiro devido ao carregamento permanente e envoltória de esforço normal (modelo básico).

Figura 4.6 - Área de aço de protensão extradorsal necessária ao variar a altura da torre. .74

Figura 4.7 - Flutuação de tensão máxima dos cabos no extradorso ao variar a altura do tabuleiro .75

Figura 4.8 - Momento fletor mínimo sobre o apoio intermediário ao variar a altura do tabuleiro. .77

Figura 4.9 - Momento fletor máximo no meio do vão central ao variar a altura do tabuleiro. .77

Figura 4.10 - Diagramas de momento fletor permanente ao variar a altura do tabuleiro, considerando a altura da torre igual a $15 \mathrm{~m}(\mathrm{~L} / 10)$. 78

Figura 4.11 - Diagramas de momento fletor permanente ao variar a altura da torre, considerando a altura do tabuleiro igual a 4,5 $\mathrm{m}(\mathrm{L} / 33)$. .78

Figura 4.12 - Envoltória de momento fletor (combinação rara) ao variar a altura do tabuleiro, considerando a altura da torre igual a $15 \mathrm{~m}(\mathrm{~L} / 10)$. .79

Figura 4.13 - Envoltória de momento fletor ao variar a altura da torre $(h=L / 33) \ldots . .79$

Figura 4.14 - Esforço normal máximo no tabuleiro ao variar a altura da torre. .80

Figura 4.15 - Flecha imediata do tabuleiro ao variar a sua altura. .80 Figura 4.16 - Envoltória de momentos fletores ao variar a tensão admissível dos cabos, considerando a altura da torre igual a $15 \mathrm{~m}(\mathrm{~L} / 10)$ e a do tabuleiro igual a 4,5 $\mathrm{m}(\mathrm{L} / 33)$. 
Figura 4.17 - Momento fletor permanente ao variar o nível de compensação de cargas permanentes, considerando $\mathrm{H}=15 \mathrm{~m}(\mathrm{~L} / 10)$ e $\mathrm{h}=4,5 \mathrm{~m}(\mathrm{~L} / 33)$

Figura 4.18 - Momentos máximos e mínimos devidos apenas aos carregamentos variáveis ao modificar o nível de compensação de cargas, considerando a altura da torre igual a $15 \mathrm{~m}(\mathrm{~L} / 10)$ e a altura do tabuleiro igual a $4,5 \mathrm{~m}(\mathrm{~L} / 33)$......................86 Figura 4.19 - Envoltórias de momento fletor ao variar o nível de compensação de cargas permanentes, considerando $\mathrm{H}=15 \mathrm{~m}(\mathrm{~L} / 10) \mathrm{e} \mathrm{h}=4,5 \mathrm{~m}(\mathrm{~L} / 33)$. .86

Figura 4.20 - Flutuação de tensão máxima dos cabos no extradorso ao variar o comprimento do vão lateral, considerando a altura da torre igual a $15 \mathrm{~m}(\mathrm{~L} / 10)$ e a altura do tabuleiro igual a $4,5 \mathrm{~m}(\mathrm{~L} / 33)$; .88

Figura 4.21 - Momento máximo no meio do vão central ao variar o comprimento do vão lateral $(\mathrm{H}=\mathrm{L} / 10 \mathrm{e} \mathrm{h}=\mathrm{L} / 33)$

Figura 4.22 - Flecha imediata no tabuleiro central ao variar o comprimento do vão lateral $(\mathrm{H}=\mathrm{L} / 10 \mathrm{e} \mathrm{h}=\mathrm{L} / 33)$

Figura 4.23 - Reação mínima nos apoios extremos ao variar o comprimento do vão lateral $(\mathrm{H}=\mathrm{L} / 10$ e $\mathrm{h}=\mathrm{L} / 33)$. .91

Figura 4.24 - Momento fletor devido ao carregamento permanente ao variar o comprimento do vão lateral, considerando $\mathrm{H}=15 \mathrm{~m}(\mathrm{~L} / 10) \mathrm{e} \mathrm{h}=4,5 \mathrm{~m}(\mathrm{~L} / 33) \ldots \ldots . .91$ Figura 4.25 - Envoltória de momento fletor ao variar o comprimento do vão lateral,

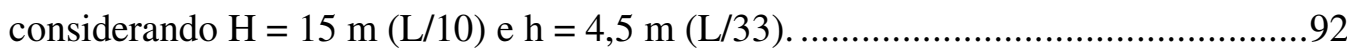

Figura 4.26 - Idealização do trecho do tabuleiro com altura variável......................93 Figura 4.27 - Envoltória de tensão na fibra superior ao longo do tabuleiro para a combinação freqüente das ações (modelo básico). .96 Figura 4.28 - Envoltória de tensão na fibra inferior ao longo do tabuleiro para a combinação freqüente das ações (modelo básico).

Figura 4.29 - Envoltória de tensão na fibra superior ao longo do tabuleiro para a combinação quase permanente das ações (modelo básico). .97 Figura 4.30 - Envoltória de tensão na fibra inferior ao longo do tabuleiro para a combinação quase permanente das ações (modelo básico) .98 Figura 4.31 - Posição e comprimento da protensão interna adotada no tabuleiro para o modelo básico .98 
Figura 4.32 - Representação de cada protensão através de carregamento equivalente.

Figura 4.33 - Diagramas de momento hiperestático devido à protensão interna unitária (modelo básico)

Figura 4.34 - Envoltória de tensão na fibra superior ao longo do tabuleiro, para a CF, considerando a protensão interna (modelo básico) 103

Figura 4.35 - Envoltória de tensão na fibra inferior ao longo do tabuleiro, para a CF, considerando a protensão interna (modelo básico). 103

Figura 4.36 - Envoltória de tensão na fibra superior ao longo do tabuleiro, para a CQP, considerando a protensão interna (modelo básico).

104

Figura 4.37 - Envoltória de tensão na fibra inferior ao longo do tabuleiro para a CQP, considerando a protensão interna (modelo básico) 104

Figura 4.38 - Momento hiperestático de protensão (modelo básico). 105

Figura 4.39 - Diagrama de momento fletor no tabuleiro devido ao carregamento permanente e envoltória de momento fletor, considerando o hiperestático de protensão (modelo básico). 105

Figura 4.40 - Envoltória de tensão na fibra superior ao longo do tabuleiro para a combinação freqüente das ações (modelo 5c).

Figura 4.41 - Envoltória de tensão na fibra inferior ao longo do tabuleiro para a combinação freqüente das ações (modelo 5c). 107

Figura 4.42 - Envoltória de tensão na fibra superior ao longo do tabuleiro para a combinação quase permanente das ações (modelo 5c). 108

Figura 4.43 - Envoltória de tensão na fibra inferior ao longo do tabuleiro para a combinação quase permanente das ações (modelo 5c). 108 Figura 4.44 - Posição e comprimento da protensão interna adotada no tabuleiro para o modelo $5 \mathrm{c}$. 109

Figura 4.45 - Envoltória de tensão na fibra superior ao longo do tabuleiro para a combinação freqüente das ações, considerando a protensão interna (modelo 5c) ...110 Figura 4.46 - Envoltória de tensão na fibra inferior ao longo do tabuleiro para a combinação freqüente das ações, considerando a protensão interna (modelo 5c) ...110 
Figura 4.47 - Envoltória de tensão na fibra superior ao longo do tabuleiro para a combinação quase permanente das ações, considerando a protensão interna (modelo $5 c)$.

Figura 4.48 - Envoltória de tensão na fibra inferior ao longo do tabuleiro para a combinação quase permanente das ações, considerando a protensão interna (modelo $5 c)$. 111

Figura 4.49 - Momento hiprestático de protensão (modelo 5c) 112

Figura 4.50 - Diagrama de momento fletor no tabuleiro devido ao carregamento permanente e envoltória de momento fletor considerando o hiperestático de protensão (modelo $5 \mathrm{c}$ )...... 112

Figura 4.51 - Diagramas de momento fletor devido à carga permanente para os modelos 5a, 5c e para a viga contínua de três vãos. 116 Figura 4.52 - Envoltórias de momento fletor para os modelos 5a, 5c e para a viga contínua de três vãos. 116

Figura 4.53 - Envoltórias de momento fletor provocados, apenas, pelas cargas variáveis (modelos $5 \mathrm{a}, 5 \mathrm{c}$ e de viga contínua de três vãos).

Figura 4.54 - Modelo estrutural simplificado para o cálculo da protensão interna, assumindo a construção pelo método dos balanços sucessivos. 119 Figura 4.55 - Associação do método dos balanços sucessivos com escoramentos móveis. 120 


\section{LISTA DE TABELAS}

Tabela 2.1 - Estados limites de serviço relativos à fissuração a serem verificados para cada tipo de protensão (NBR6118, 2003). 8

Tabela 2.2 - Algumas pontes com protensão no extradorso construídas até 2001 e as duas pontes brasileiras.

Tabela 2.3 - Resistência à fadiga de cordoalhas a 2 milhões de ciclos (adaptado de SETRA, 2001). .47

Tabela 2.4 - Resultados em escala real do comportamento do sistema de ancoragem da ponte Odawara Blueway, no Japão (CHO, 2000).

Tabela 3.1 - Propriedades geométricas das seções transversais adotadas nas torres..55 Tabela 3.2 - Propriedades geométricas das seções transversais adotadas em todos os

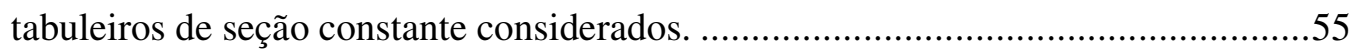

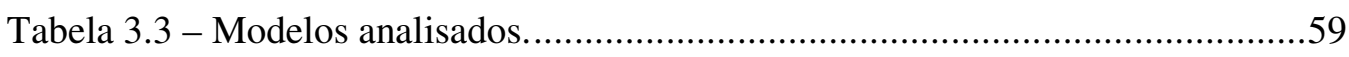

Tabela 3.4 - Peso próprio da viga longitudinal e das transversinas.........................59

Tabela 3.5 - Protensão necessária nos cabos extradorsais........................................66

Tabela 3.6 - Área de aço referente à tensão no ato da protensão igual a 1045 MPa. 67

Tabela 3.7 - Determinação da área de aço necessária para o modelo básico.

Tabela 4.1 - Protensão, tensão máxima e mínima, área de aço e flutuação de tensão dos cabos no extradorso do modelo básico.

Tabela 4.2 - Protensão média, área de aço extradorsal e variação de tensão dos cabos ao variar a altura da torre e a altura do tabuleiro.

Tabela 4.3 - Alguns esforços no tabuleiro ao variar a altura da torre e a altura do tabuleiro. .76

Tabela 4.4 - Área de aço extradorsal e flutuação de tensão nos tirantes ao variar a tensão admissível dos cabos. .81

Tabela 4.5 - Alguns esforços no tabuleiro ao variar o nível de tensão dos cabos. ....82 Tabela 4.6 - Área de aço extradorsal e flutuação de tensão máxima ao variar o nível de compensação de cargas. .84 Tabela 4.7 - Alguns esforços no tabuleiro ao variar o nível de compensação de cargas permanentes. 
Tabela 4.8 - Área de aço extradorsal e flutuação de tensão máxima ao variar o comprimento do vão lateral.

Tabela 4.9 - Alguns esforços no tabuleiro ao variar o comprimento do vão lateral. .89 Tabela 4.10 - Protensão, tensão máxima e mínima, área de aço e flutuação de tensão

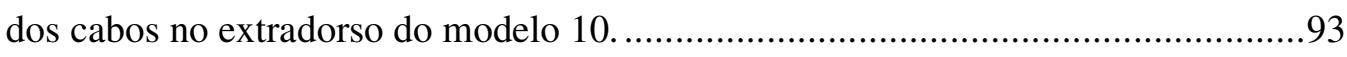
Tabela 4.11 - Seções críticas, tensões de tração a serem combatidas e a relação entre momento hiperestático e protensão (modelo básico). 101

Tabela 4.12 - Área de aço extradorsal considerando a protensão interna (modelo básico). 106

Tabela 4.13 - Área de aço extradorsal considerando a protensão interna (modelo 5c). 113

Tabela 4.14 - Peso de aço de protensão (modelo 5a e 5c). 113

Tabela 4.15 - Tensão máxima nos cabos extradorsais considerando a combinação

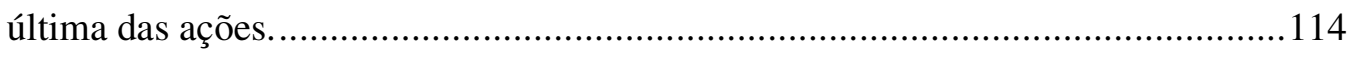

Tabela 4.16 - Alguns esforços solicitantes e flechas imediatas.............................115 Tabela 4.17 - Protensão extradorsal, considerando a interna no apoio intermediário, em função da construção por balanços sucessivos. 120 


\section{니STA DE SÍMBOLOS}

\section{$\underline{\text { Letras romanas minúsculas }}$}

$\begin{array}{ll}a & - \text { Flecha imediata no tabuleiro } \\ a_{\text {perm }} & - \text { Flecha imediata no tabuleiro devido às cargas permanentes } \\ f_{\mathrm{ck}} & - \text { Resistência característica à compressão do concreto } \\ f_{c t, f} & - \text { Resistência do concreto à tração na flexão } \\ f_{c t k, i n f} & - \text { Resistência característica inferior do concreto à tração direta } \\ f_{\mathrm{ptk}} & - \text { Resistência última característica do aço de protensão } \\ \mathrm{h} & - \text { Altura do tabuleiro } \\ \mathrm{h}_{\mathrm{a}} & - \text { Altura do tabuleiro no apoio intermediário } \\ \mathrm{h}_{\mathrm{c}} & - \text { Altura do tabuleiro no trecho central do tabuleiro } \\ \mathrm{w}_{\mathrm{k}} & - \text { Abertura característica de fissuras na superfície do concreto } \\ \mathrm{y}_{\mathrm{i}} & \quad-\text { Distância do centro de gravidade da seção à fibra extrema inferior } \\ \mathrm{y}_{\mathrm{s}} & - \text { Distância do centro de gravidade da seção à fibra extrema superior }\end{array}$

\section{$\underline{\text { Letras romanas maiúsculas }}$}

A $\quad-$ Área da seção transversal

$\mathrm{A}_{\mathrm{p}} \quad-$ Área da seção transversal cabo protendido

$\mathrm{A}_{\mathrm{p}, \text { total }}$ - Soma da área de aço extradorsal de todos os cabos

$\mathrm{E}_{\mathrm{c}} \quad-$ Módulo de elasticidade do concreto

$\mathrm{E}_{\mathrm{p}} \quad-$ Módulo de elasticidade do aço protendido

E* - Módulo de elasticidade de Dischinger

$\mathrm{H} \quad-$ Altura da torre

I - Momento de inércia da seção transversal

L - Comprimento do vão principal ou vão central

$\mathrm{L}_{\mathrm{H}} \quad$ - Projeção horizontal do comprimento do cabo no extradorso

$\mathrm{L}_{\mathrm{i}} \quad$ - Distância entre cada cabo do grupo i e a torre

$\mathrm{L}_{1} \quad$ - Comprimento do vão lateral

$\mathrm{L}_{\mathrm{V}}$ - Projeção vertical do comprimento do cabo no extradorso 


$\begin{array}{ll}M & - \text { Momento fletor } \\ M_{\text {máx }} & - \text { Momento fletor máximo } \\ \mathrm{M}_{\text {mín }} & - \text { Momento fletor mínimo } \\ \mathrm{M}_{\text {perm }} & - \text { Momento fletor devido às cargas permanentes } \\ \mathrm{M}_{\mathrm{q}} & - \text { Momento fletor devido às cargas variáveis } \\ \mathrm{N} & - \text { Esforço normal } \\ \mathrm{N}_{\text {ciclos }} & - \text { Número de ciclos de flutuação de tensão } \\ \mathrm{N}_{\text {máx }} & - \text { Esforço normal máximo } \\ \mathrm{N}_{\text {mín }} & - \text { Esforço normal mínimo } \\ \mathrm{N}_{\text {perm }} & - \text { Esforço normal devido às cargas permanentes } \\ \mathrm{N}_{\mathrm{q}} & - \text { Esforço normal devido às cargas variáveis } \\ \mathrm{P} & - \text { Força de protensão } \\ \mathrm{P}_{\mathrm{i}} & - \text { Força de protensão no cabo i } \\ \mathrm{P}_{\text {média }} & - \text { Força de protensão extradorsal média } \\ \mathrm{R}_{\mathrm{i}} & - \text { Reação de apoio correspondente ao grupo de cabos i } \\ \mathrm{X}_{\mathrm{p}} & - \text { Momento hiperestático de protensão } \\ \end{array}$

\section{Letras gregas minúsculas}

$\alpha_{i} \quad-$ Ângulo do cabo no extradorso i em relação a horizontal

$\alpha_{\text {máx }} \quad-$ Ângulo de rotação máxima nas ancoragens do cabo no extradorso

$\alpha_{\text {mín }} \quad-$ Ângulo de rotação mínimo nas ancoragens do cabo no extradorso

$\gamma \quad-$ Peso específico

$\gamma_{c}-$ Peso específico do concreto estrutural

$\gamma_{\mathrm{p}} \quad-$ Peso específico do aço protendido

$\sigma_{\mathrm{adm}} \quad-$ Tensão admissível dos cabos no extradorso para a combinação rara das ações

$\sigma_{\mathrm{m}} \quad-$ Tensão média

$\sigma_{\text {máx }} \quad-$ Tensão máxima

$\sigma_{\text {máx, i }} \quad-$ Tensão máxima em cada cabo do grupo i

$\sigma_{\text {mín }} \quad-$ Tensão mínima 


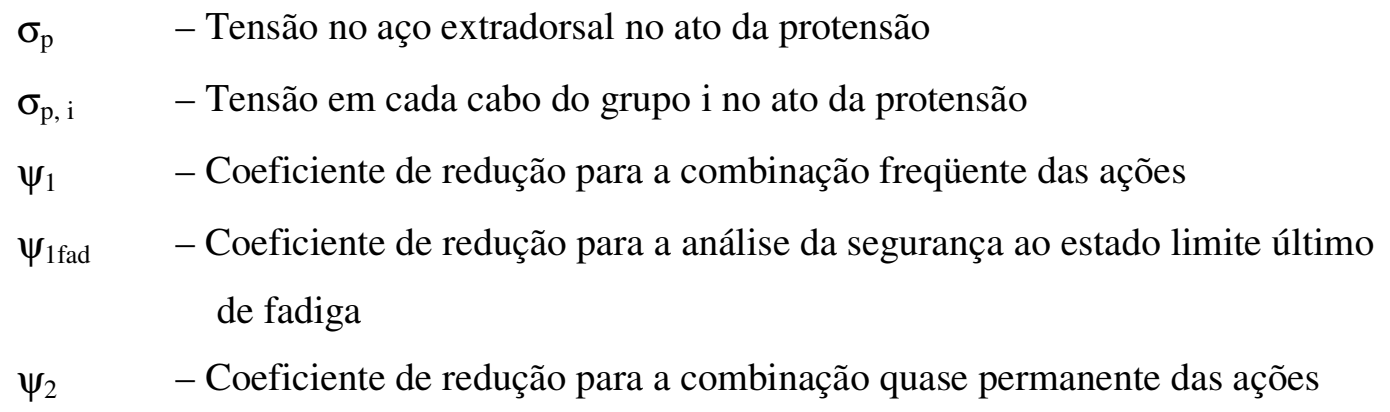

\section{Letras gregas maiúsculas}

$\Delta \sigma \quad-$ Flutuação de tensão

$\Delta \sigma_{\text {fad }} \quad-$ Resistência limite à fadiga

$\Delta \sigma_{\mathrm{p}} \quad$ - Flutuação de tensão no aço de protensão

$\Delta \sigma_{\mathrm{p} \text {,máx }} \quad$ - Flutuação de tensão máxima dentre os cabos no extradorso 


\section{INTRODUÇão}

\subsection{GENERALIDADES E JUSTIFICATIVAS}

A ponte com protensão no extradorso é um novo conceito estrutural definido por MATHIVAT (1988) como sendo uma solução intermediária entre a ponte de concreto com protensão externa e a ponte estaiada.

A morfologia estrutural desse tipo de ponte se assemelha com a das estaiadas modernas, porém a utilização de torres menores e alturas maiores no tabuleiro permitem associar as vantagens do concreto protendido com a utilização de tirantes.

A idéia foi desenvolvida em um estudo para o viaduto Arrêt Darré na França, que infelizmente não foi escolhido. A primeira aplicação deste tipo estrutural foi em 1994 com a construção da ponte Odawara Blueway no Japão (figura 1.1). Desde então várias pontes vêm sendo construídas com a mesma tecnologia, onde se pode destacar a Kiso River no Japão, que possui o vão principal de 275 m, e as pontes sobre o Rio Acre e a integração Brasil-Peru, que são as primeiras com protensão no extradorso do Brasil.

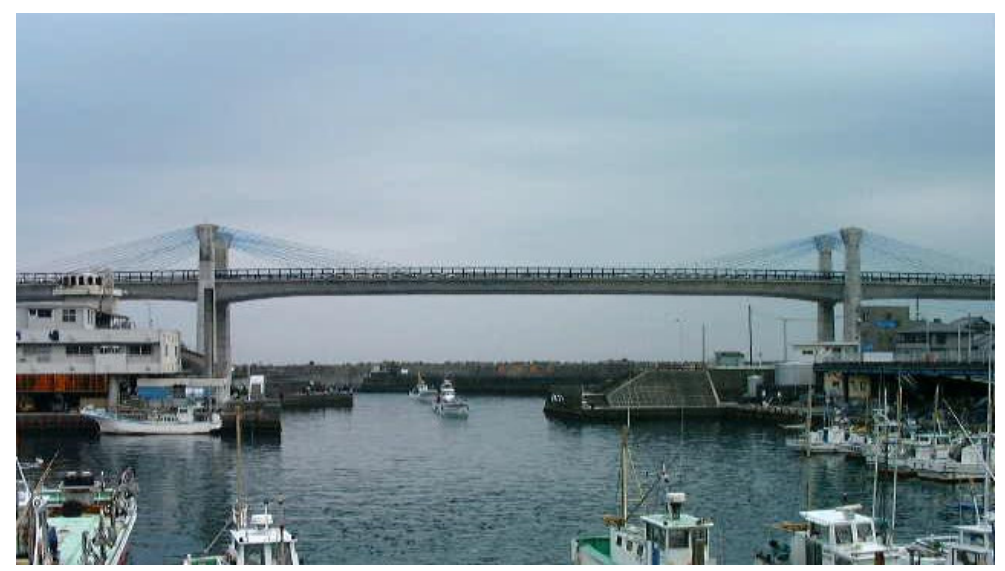

Figura 1.1 - Ponte Odawara Blueway, Japão (1994). 
A limitada altura da torre em relação ao vão proporciona um aspecto estético bastante interessante em locais onde se deseja que a ponte não entre em conflito com a paisagem em volta. Além disso, em locais próximos a aeroportos e que necessitam de grandes vãos livres para a navegação essa solução parece ser a ideal.

Ao dispor de tabuleiros mais rígidos em relação às pontes estaiadas, as com protensão no extradorso possuem flutuações de tensões menores nos tirantes, amenizando assim, os efeitos de fadiga que podem ocorrer, o que possibilita o emprego de uma tensão admissível, para a combinação rara das ações, maior no aço de protensão. $\mathrm{O}$ valor que vem sendo utilizado nas construções existentes é de $60 \%$ da resistência última, enquanto em estais o usual é entre $40 \%$ e $45 \%$.

A aplicação da protensão acima da viga com o auxilio de pequenas torres, na verdade, não é tão nova, pois, ao longo dos anos, algumas pontes utilizaram essa prática nas suas etapas construtivas. Um exemplo é a ponte Ganter na Suíça (1980) que possui uma torre relativamente pequena, porém após a construção do tabuleiro os tirantes foram cobertos por um painel de concreto.

Em pontes de concreto protendido construídas por balanços sucessivos, é necessária uma grande quantidade de cabos na parte superior da viga na fase construtiva. A depender do comprimento do vão, podem surgir problemas para posicionar as bainhas com intuito de manter uma excentricidade desejável. Ao utilizarmos à solução da protensão no extradorso, é possível aumentar consideravelmente a excentricidade e ao mesmo tempo atribuir ao aço de protensão a função de tirante, permitindo assim, que o transporte das cargas aos apoios seja realizado pela interação do cabo via tração axial e do tabuleiro a flexão.

Embora haja um crescimento na construção de pontes com protensão no extradorso, ainda existem poucos trabalhos disponíveis e, mesmo assim, estes são incompletos e com dados não divulgados. Portanto, cabe aos estudos científicos preencher essa lacuna. É muito importante evidenciar os benefícios e as dificuldades dessa técnica, no intuito de orientar os engenheiros de pontes nas tomadas de decisões que norteiam o projeto desse tipo de obra de arte. 


\subsection{OBJETIVOS}

O objetivo deste trabalho é fornecer subsídios para a concepção de uma ponte com protensão no extradorso, analisando o seu comportamento através de modelos estruturais bem definidos. Para tanto, os objetivos específicos são:

$>$ Reunir informações a partir da bibliografia existente e de utilizações práticas, analisando-as criticamente, de forma a elaborar um estudo da arte sobre o assunto;

$>$ Estudar e quantificar os parâmetros que definem as pontes com protensão no extradorso e que as diferenciam das estaiadas e as de concreto protendido convencionais;

$>$ Definir modelos estruturais com base na proposta de MATHIVAT (1988) e das construções existentes, de forma a estabelecer critérios para o prédimensionamento deste tipo de ponte;

$>$ Analisar o comportamento estático da fase final;

$>$ Estudar a fadiga do aço de protensão, questão importante na definição da tensão admissível dos cabos no extradorso e da flutuação de tensão máxima que pode ser empregada nos cabos sem que haja perda de resistência significativa.

\subsection{APRESENTAÇÃO DO TRABALHO}

Este trabalho está dividido em cinco capítulos, incluindo este introdutório.

O Capítulo 2 contém uma revisão bibliográfica. Inicialmente é realizada uma conceituação das pontes com protensão no extradorso. Com o intuito de aprofundar e consolidar tais idéias, foi feita uma revisão dos conceitos básicos das pontes de concreto com protensão interna e externa, além das estaiadas, de forma a extrair informações vitais para o entendimento do comportamento estrutural da ponte em estudo. Em seguida, são citados vários exemplos de pontes com protensão extradorsal, onde são retiradas diversas conclusões. Por fim, é conduzido um estudo 
de fundamental importância para o projeto das pontes com protensão no extradorso que é a análise do comportamento de cabos pós-tensionados à fadiga.

No Capítulo 3, é descrita a análise paramétrica, apresentando as características de todos os modelos que foram elaborados, relacionando cada um com os parâmetros que se deseja estudar.

Os resultados obtidos do estudo paramétrico são examinados no Capítulo 4. Esta análise é feita através de comparação entre modelos com o auxílio de tabelas e gráficos.

No Capitulo 5, são apresentadas as conclusões obtidas no trabalho e as recomendações para pré-dimensionamento de uma ponte com protensão no extradorso, além de sugestões para trabalhos futuros dentro da mesma linha de pesquisa. 


\section{REVISÃO BIBLIOGRÁFICA}

\subsection{GENERALIDADES}

Nos últimos anos, as pontes de concreto protendido e as estaiadas se tornaram bastante difundidas no meio técnico. O domínio da tecnologia empregada em ambas vem permitindo a criação de novas configurações, nas quais a liberdade de projeto tem desenvolvido pontes com qualidades estéticas cada vez melhores. Isto ocorre com uma nova tipologia estrutural: as pontes com protensão no extradorso.

A obra pioneira, em termos de evolução, das pontes com protensão no extradorso é a famosa ponte Ganter (figura 2.1) projetada por Christian Menn. A viga celular de concreto é "estaiada" através de painéis de concreto protendido que a "suspende" por uma torre muito pequena. No entanto, esta ponte tem sido muito mais admirada por sua elegância estrutural e perfeita integração com a paisagem da montanha suíça, do que sua por inovação tecnológica (VIRLOGEUX, 1999).

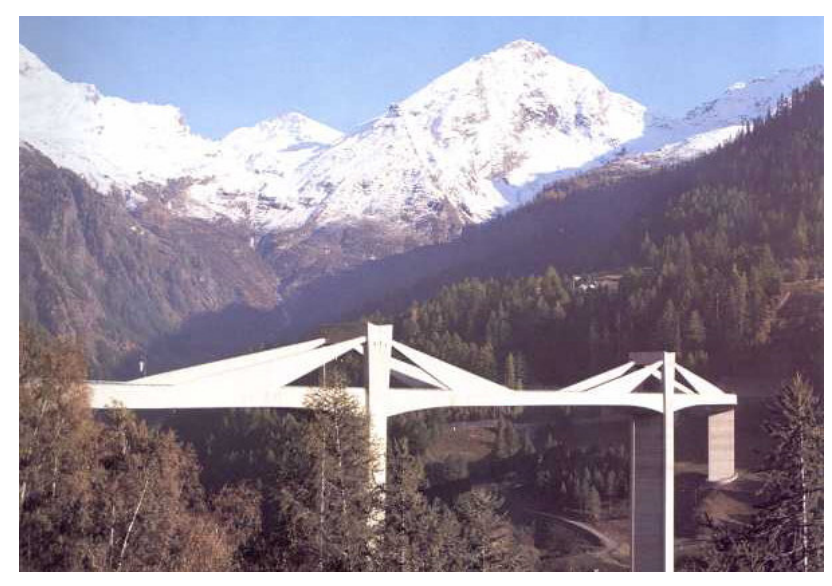

Figura 2.1 - Ponte Ganter, Suíça (1980). 
A utilização do painel de concreto permite empregar o sistema de protensão do concreto protendido clássico. Contudo, esse tipo de ponte tem algumas desvantagens, como a impossibilidade de substituição dos cabos e o custo de montagem desses painéis. Por isso, poucas pontes foram construídas da mesma forma, como por exemplo: a ponte Socorridos (1993) em Portugal que possui um plano central de cabos.

A principal diferença entre os estais e os sistemas de cabos pós-tensionados tradicionais é a influência da fadiga no projeto. Em estruturas de concreto protendido a oscilação da tensão nos cabos em serviço é pequena e, normalmente, a resistência à fadiga não é um fator limitante. Entretanto, nas pontes estaiadas, esta oscilação é elevada, sendo necessário o uso de uma tensão admissível relativamente baixa, além de dispositivos de ancoragens mais sofisticados.

Em conseqüência disto, é lógico aceitar que a fadiga é um ponto fundamental na diferenciação dos sistemas de cabos protendidos, que podem ser divididos em três grupos fundamentais (Figura 2.2):

(a) Pequena excentricidade: $\mathrm{O}$ transporte das cargas até os apoios é realizado basicamente por flexão da viga. Por exemplo: concreto protendido com protensão interna e externa.

(b) Moderada excentricidade: O transporte das cargas até os apoios é realizado com a colaboração da viga à flexão e do sistema de cabos à tração. Por exemplo: pontes com protensão no extradorso.

(c) Grande excentricidade: O transporte das cargas até os apoios é realizado basicamente pelo sistema de cabos à tração. Por exemplo: pontes estaiadas modernas.

O sistema de cabos protendidos de pequena excentricidade (a) é de simples diferenciação em relação aos outros, pois, normalmente, a posição dos cabos se limita às fibras extremas da viga. No caso dos sistemas (b) e (c), essa diferenciação não é tão clara. Não existe uma excentricidade específica que os limita, no entanto, conforme será visto neste trabalho, ela pode ser medida indiretamente pelos fenômenos de fadiga associados aos cabos de ambos os sistemas. 
(a)

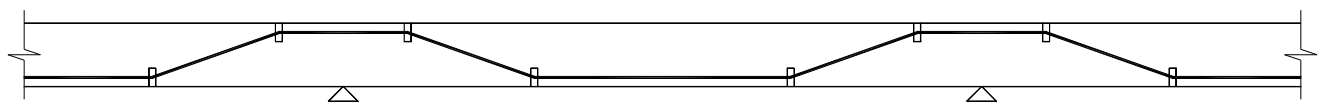

(b)
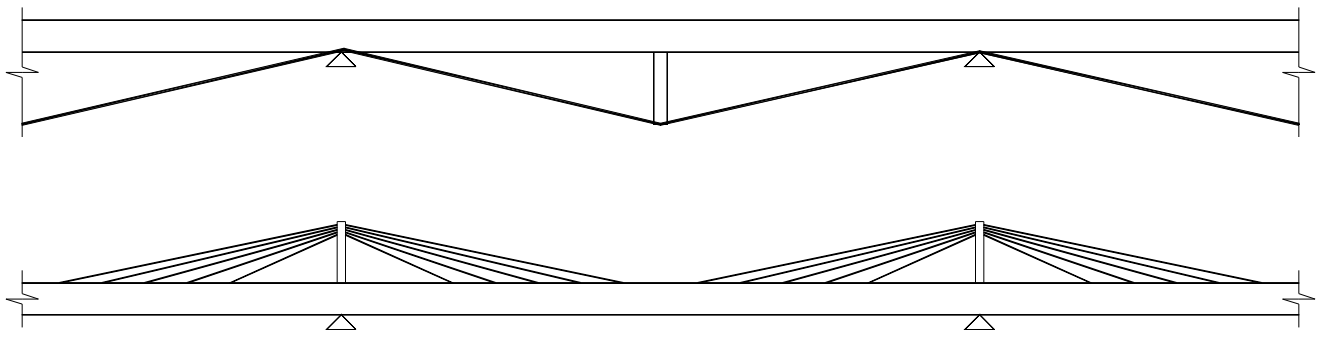

(c)

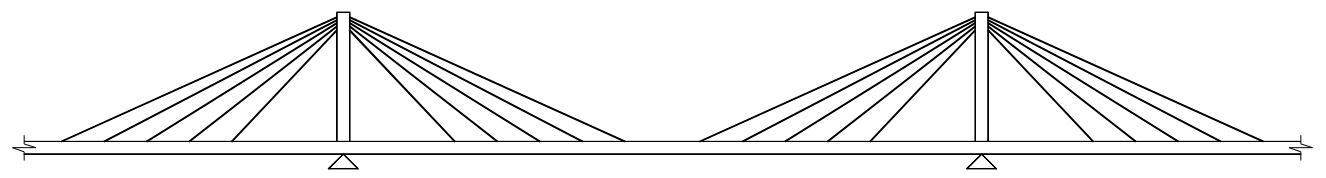

Figura 2.2 - Sistemas de cabos protendidos de pequena excentricidade, (a) moderada excentricidade (b) e grande excentricidade (c).

Podemos definir a protensão extradorsal como sendo aquela que sobressai da altura do tabuleiro, por cima ou por baixo, de forma que o sistema de protensão empregado seja tecnologicamente similar ao dos cabos externos pós-tensionados. No entanto, será adotada a nomenclatura usual encontrada na literatura que é: protensão no extradorso quando os cabos se posicionarem acima do tabuleiro e suportada por cabos protendidos inferiores quando estiverem abaixo.

Segundo MATHIVAT (1980), a ponte tradicional de concreto protendido é limitada do ponto de vista técnico e econômico em um vão livre de 150 m. Embora algumas pontes tenham sido construídas com vãos superiores, esse tipo de obra começa a ter muitos inconvenientes. Acima de $150 \mathrm{~m}$, começa o campo de aplicação das pontes estaiadas, porém o custo das construções para vãos inferiores a $250 \mathrm{~m}$ é elevado. Surgindo assim, a ponte com protensão no extradorso que é uma transição econômica entre ambas.

O presente capítulo visa expor os aspectos relevantes do comportamento estrutural das pontes com protensão no extradorso. Para tanto, mostra-se necessário, como ponto de partida, rever as idéias e conceitos básicos que regem as pontes de 
concreto protendido e as estaiadas, incluindo o comportamento quanto à fadiga dos cabos protendidos, de forma a estabelecer as características principais que serão levadas em consideração no estudo paramétrico.

\subsection{PONTES DE CONCRETO PROTENDIDO}

A idéia da protensão é muito antiga e já era utilizada em barris de madeira e rodas de carreta. A primeira proposição de se pré-comprimir o concreto foi feita em 1886 por P. H. Jackson (LEONHARDT, 1983), a partir daí, várias experiências foram realizadas, mas os efeitos das perdas de protensão devido à retração e à fluência do concreto praticamente anulavam o pré-alongamento das barras.

O desenvolvimento da prática do concreto protendido é atribuído ao engenheiro francês Eugene Freyssinet que, em 1928, utilizou arames refilados de alta resistência para resolver o problema das perdas progressivas.

O campo de aplicação do concreto armado é limitado pela sua fissuração. Contudo, o emprego da protensão permite a eliminação ou a redução das tensões de tração no elemento estrutural, de forma a suprimir as fissuras para as combinações de carregamentos externos desejados. Adicionalmente, é possível controlar os deslocamentos, melhorando sensivelmente o comportamento em serviço, o que resulta em maiores vãos e estruturas mais esbeltas.

Normalmente, o cálculo da protensão necessária é realizado considerando os estados limites de serviço relativos à fissuração da estrutura (tabela 2.1). Em casos especiais pode-se determinar a protensão em função da deformabilidade da mesma, assim como ocorre nas pontes estaiadas.

Tabela 2.1 - Estados limites de serviço relativos à fissuração a serem verificados para cada tipo de protensão (NBR6118, 2003).

\begin{tabular}{|c|c|c|}
\hline Tipos de protensão & $\begin{array}{c}\text { Exigências relativas à } \\
\text { fissuração }\end{array}$ & $\begin{array}{c}\text { Combinação de ações } \\
\text { a ser verificada }\end{array}$ \\
\hline Protensão parcial & $\begin{array}{c}\text { ELS - W } \\
\mathrm{w}_{\mathrm{k}} \leq 0,2 \mathrm{~mm}\end{array}$ & Freqüente \\
\hline Protensão limitada & ELS - F & Freqüiente \\
\cline { 2 - 3 } & ELS - D & Quase permanente \\
\hline \multirow{2}{*}{ Protensão completa } & ELS - F & Rara \\
\cline { 2 - 3 } & ELS - D & Freqüente \\
\hline
\end{tabular}


Sendo que os estados limites de serviço são:

$>$ Estado limite de abertura das fissuras (ELS - W): Estado em que a abertura de fissura máxima é igual a um valor determinado (para concreto protendido, $\left.\mathrm{w}_{\mathrm{k}}=0,2 \mathrm{~mm}\right)$;

$>$ Estado limite de formação de fissuras (ELS - F): Estado em que se inicia a formação de fissuras. Admite-se que isto ocorre quando a tensão de tração máxima na seção transversal for igual à resistência à tração do concreto;

$>$ Estado limite de descompressão (ELS - D): Estado no qual em um ou mais pontos da seção transversal a tensão é nula, não havendo tração no restante da seção.

O concreto protendido sempre cumpriu uma dupla função. Em primeiro lugar, é uma ação que se introduz na estrutura com o intuito de modificar o efeito de outras ações. A segunda é servir de armadura resistente. Todavia, esta técnica, totalmente consolidada, está experimentando uma evolução interessante. Sua função como ação tem sido incrementada, abrindo novas possibilidades, enquanto a sua função como armadura passiva se reduz. Da protensão interna aderente para a externa, depois para a protensão extradorsal e deste ultimo aos estais (MANTEROLA, 1997).

\subsubsection{Protensão interna aderente}

Assim como o concreto armado, o desenvolvimento inicial do concreto protendido se deu devido aos seguintes fatores:

A boa aderência da superfície de aço com o concreto;

Os coeficientes de dilatação do aço e do concreto são aproximadamente iguais. 
A aderência entre o aço e o concreto permite que acréscimos de carregamentos resultem em incrementos de deformações iguais no cabo e no concreto vizinho ao mesmo, ou seja, existe uma compatibilidade de deformações.

As primeiras aplicações da protensão interna foram com o sistema de protensão chamado de pré-tração, onde o pré-alongamento do aço é realizado com o auxílio de apoios independentes antes do lançamento do concreto. Tempos depois, foi desenvolvido outro sistema de protensão, onde a armadura é ancorada no próprio elemento estrutural, após o seu endurecimento e a aderência é realizada posteriormente através de injeção de nata de cimento.

Esse novo método, chamado de pós-tração, permite que a protensão seja realizada com a peça estrutural no seu local definitivo e, somado a isso, o desenvolvimento de fios e cordoalhas possibilita um traçado de cabo que acompanha o diagrama de momentos fletores do elemento estrutural.

Devido a disposições construtivas, em vigas contínuas, não é possível fazer um traçado de cabo que tenha a mesma lei de variação dos momentos fletores. No entanto, ao combinar a protensão interna com a extradorsal (figura 2.3, item (b)), isso é possível e incrementa a eficiência da protensão.

(a)
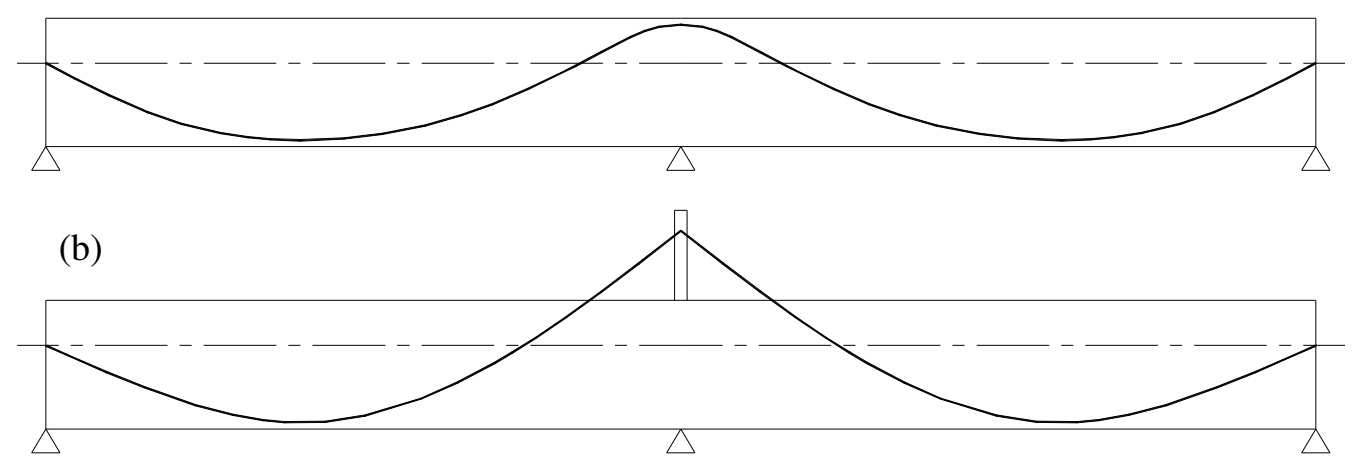

Figura 2.3 - Exemplos de traçado de cabos para vigas de dois vãos, (a) protensão interna e (b) combinação da protensão interna com a extradorsal.

A primeira aplicação de um traçado combinando a protensão interna e a extradorsal foi utilizada na ponte Saint-Rémy-de-Maurienne (1996) na França. Outro exemplo é a ponte sobre o rio Deba (Figura 2.4), na Espanha. São três vãos de 42, 66 e $42 \mathrm{~m}$, o tabuleiro é em formato de $\mathrm{U}$ e ambas as nervuras têm $2,7 \mathrm{~m}$. de altura. $\mathrm{O}$ 
traçado dos cabos é similar ao da figura 2.3 item (a), sendo que a maioria deles ultrapassa a fibra superior, se tornando externo ao tabuleiro.

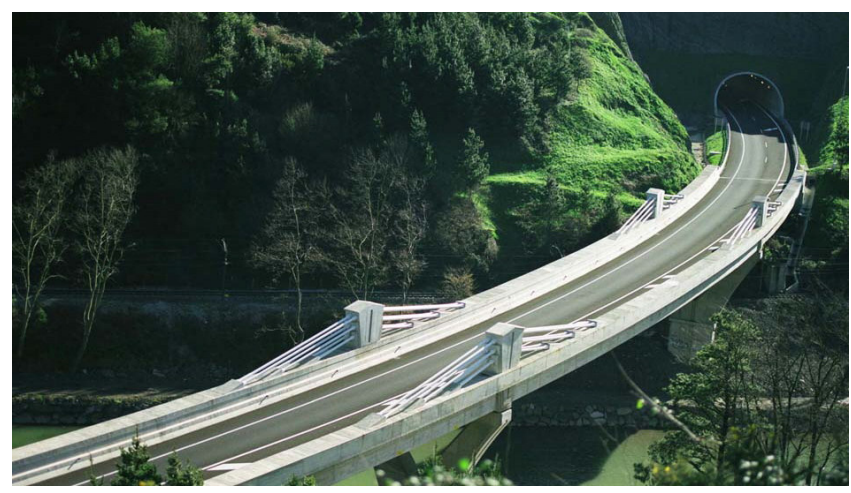

Figura 2.4 - Ponte sobre o rio Deba, Espanha (2004).

\subsubsection{Protensão interna não aderente}

Protensão não aderente é aquela na qual a armadura está livre para deslizar em relação ao concreto, ao longo de toda a viga, exceto nos pontos de ancoragem. $\mathrm{O}$ fato de não haver aderência faz com que a compatibilidade de deformações em cada seção não seja mais válida. Entretanto, a variação do comprimento do cabo não aderente é equivalente à integral das deformações do concreto ao longo do traçado do cabo, caracterizando assim, uma compatibilidade de deslocamentos que pode ser descrita da seguinte forma:

$$
\Delta l_{p}=\int \varepsilon_{c, p} d x
$$

Com isso, após as perdas por atrito e encunhamento, a variação de tensão da armadura aderente é constante entre as ancoragens e dada por:

$$
\Delta \sigma_{p}=E_{p} \frac{\Delta l_{p}}{l_{p}}
$$


Esta variante da protensão aderente tem sido largamente utilizada em edifícios e não em pontes. Contudo, os sistemas de protensão com monocordoalhas engraxadas e bainha plástica extrudada também são bastante utilizados na protensão externa.

O desenvolvimento de protensão sem aderência tem possibilitado, também, o emprego de armaduras não metálicas, como fibras sintéticas que têm alta resistência à tração e uma ótima resistência à corrosão.

\subsubsection{Protensão externa}

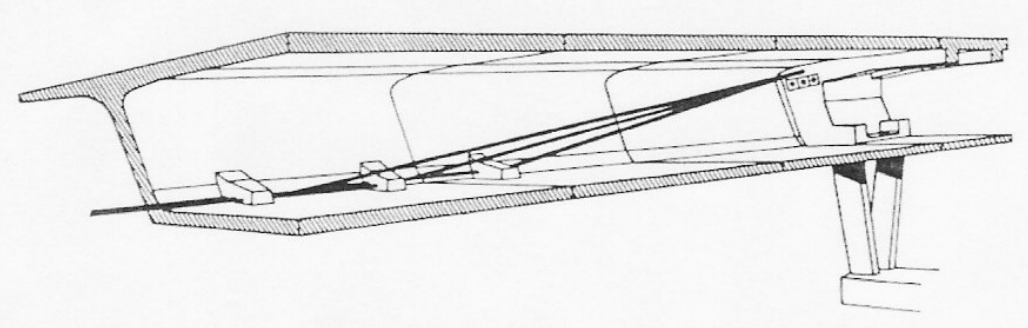

Figura 2.5 - Ponte Long Key - Disposição da protensão externa.

A primeira aplicação da protensão externa se deu ainda nas primeiras idades do concreto protendido. Na Alemanha, Franz Dischinger, em 1934, garantiu a patente pela utilização de vigas de concreto com barras externas protendidas. Em 1936, ele projetou a primeira ponte de concreto protendido em Aue na Alemanha que utilizava cabos externos. O uso de barras de aço com baixa tensão de escoamento, assim como nas primeiras aplicações da protensão interna, foi um erro, já que devido à fluência, à retração do concreto e à relaxação do aço o efeito da protensão se perdeu.

A protensão externa era vista como um meio de evitar a patente de Freyssinet e, com isso, diversas pontes foram construídas com esta técnica, principalmente na Bélgica, França, Alemanha e Inglaterra. Porém, a protensão externa esbarrou em uma dificuldade, a corrosão do aço. Muitas obras tiveram sérios problemas de corrosão, sendo necessário efetuar reparos, como substituição de cabos e até a demolição de algumas pontes. 
Em virtude dessas experiências mal sucedidas, dos custos de algumas aplicações, da tecnologia limitada na época e do conhecimento insuficiente sobre o comportamento estrutural, a protensão externa adquiriu uma imagem ruim.

A utilização de cabos externos foi praticamente abandonada nos anos sessenta e setenta, mas nos anos oitenta, devido à necessidade de reforço de muitas pontes com protensão interna que apresentavam problemas de fissuração, uma vez que as perdas de protensão tinham sido subestimadas, essa técnica foi revitalizada.

Outros fatores que contribuíram para o retorno dessa prática foram os desenvolvimentos de cordoalhas de alta resistência e de sistemas mais adequados de proteção contra a corrosão.

A protensão externa tem prosperado quando se pretende controlar o estado de conservação da protensão e a possibilidade de sua substituição. Esta técnica também tem sido largamente utilizada em reforço de estruturas devido ao seu caráter ativo. Outras vantagens em relação à protensão aderente são: redução do peso da estrutura e melhores condições de concretagem em virtude da ausência de bainhas ou cabos no interior da seção; facilidade na instalação, nas operações de protensão dos cabos e de inspeção e simplificação do traçado.

Por outro lado, existem algumas desvantagens que são: maior vulnerabilidade em relação a atos de vandalismo; maior exposição à agressividade do próprio ambiente e ao fogo; os sistemas de protensão externa tendem a ser mais caros e maior consumo de aço passivo.

A maior dificuldade do uso da protensão externa em pontes de grandes vãos é a grande quantidade de ancoragens intermediárias necessárias, sendo usual a utilização de uma solução mista, na qual parte da protensão é externa e parte interna aderente. Apesar disso, a protensão externa parece ter um futuro promissor, devido, principalmente, à grande preocupação atual com a durabilidade das estruturas. Além disso, tem permitido o desenvolvimento de pontes mistas protendidas (fig. 2.6), onde a alma da seção transversal é substituída por elementos metálicos com o intuito de reduzir o peso próprio que é grande parte do carregamento total das pontes de concreto. 


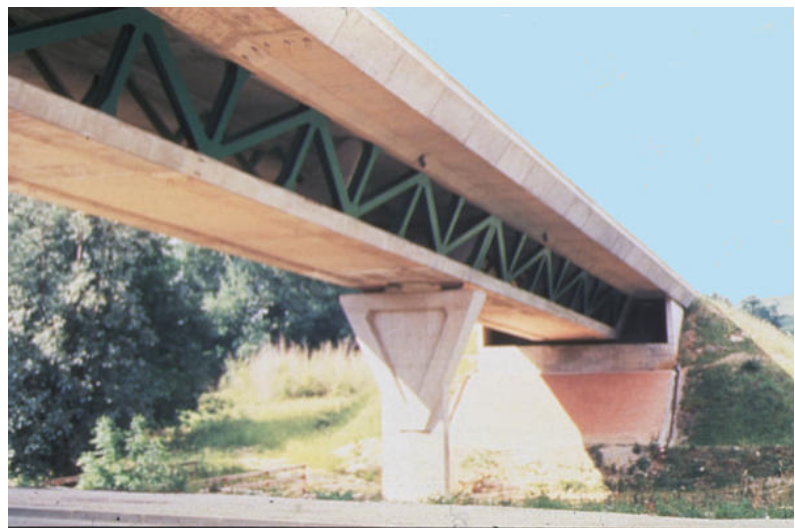

Figura 2.6 - Ponte Arbois (França, 1985).

\subsubsection{Construção de pontes de concreto pelo método dos balanços sucessivos}

O método dos balanços sucessivos consiste em construir o tabuleiro de uma ponte por meio de aduelas que avançam em balanço, para os dois lados, de um pilar ou torre (figura 2.7). As aduelas a serem montadas são unidas a anterior por medidas auxiliares e no momento em que o concreto adquire resistência suficiente estas medidas são removidas.

(a)

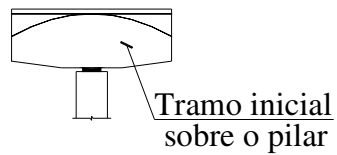

(b)

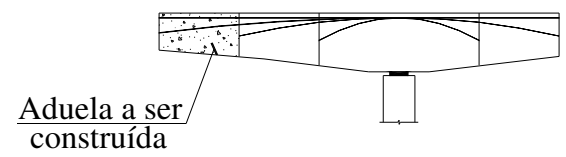

(c)

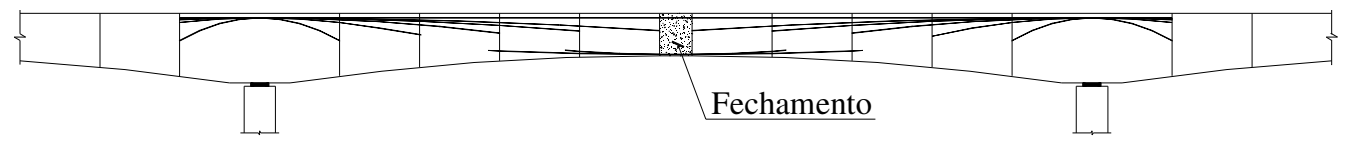

Figura 2.7 - Construção por balanços sucessivos (ponte em viga), (a) tramo inicial, (b) fase intermediária e (c) fechamento do vão.

Esse processo era utilizado anteriormente em construções de madeira e metálicas, com a primeira aplicação datada de 1811, realizada por Thomas Pope em uma ponte de madeira com vão de $550 \mathrm{~m}$. A primeira aplicação em concreto foi na ponte de Herval, no Brasil, projetada por Emilio Baumgart, em 1930. Esta obra, destruída por uma enchente em 1983, foi mencionada em inúmeras revistas 
internacionais. No entanto, este tipo de construção em concreto armado tinha muitos inconvenientes e era muito lenta.

O concreto protendido impulsionou a técnica dos balanços sucessivos. O engenheiro alemão Finsterwalder inicia o desenvolvimento do método ao construir a ponte sobre o rio Lahn, em 1951, que possui 62m de vão.

A partir daí, a evolução da construção das pontes de concreto protendido por este procedimento acelerou de forma notável. O sistema se difundiu e experimentou numerosos aperfeiçoamentos, tanto em sistemas auxiliares e tecnológicos, como em esquemas estáticos (CHO, 2000).

A lentidão da construção utilizando o concreto moldado no local e as importantes deformações por fluência e retração do concreto são bastante reduzidas ao utilizar aduelas pré-moldadas.

A principal vantagem do método dos balanços sucessivos é eliminar o escoramento, liberando o espaço situado abaixo da obra. Este procedimento se adapta particularmente bem nas seguintes condições locais (MATHIVAT, 1980):

$>$ Vales largos e profundos com necessidade de pilares com grande altura (os escoramentos têm custo elevado);

$>$ Rios com correntezas fortes;

$>$ Necessidade de um vão livre para circulação de veículos ou navegação sob a obra durante a construção.

O campo de aplicação das pontes de concreto protendido construídas por balanços sucessivos, do ponto de vista técnico e econômico, começa em um vão de, aproximadamente, $60 \mathrm{~m}$ e vai até $120 \mathrm{~m}$, podendo chegar a $150 \mathrm{~m}$. Estes tipos de pontes são condicionados pelos momentos fletores durante a construção.

Uma possibilidade construtiva é o uso de tirantes provisórios para sustentação das aduelas, com o intuito de reduzir os momentos durante a construção. Esta solução tem sido empregada em poucas pontes, devido aos custos das torres e dos tirantes provisórios.

Entretanto, é interessante observar que mais um argumento para o desenvolvimento das pontes com protensão no extradorso é a construção pelo 
método dos balanços sucessivos, pois se os tirantes fossem definitivos, teríamos o mesmo esquema estrutural de tais pontes.

De fato, a proposta para o viaduto Arrêt Darré, no qual MATHIVAT (1988) introduziu o conceito, tinha como premissa principal a utilização de protensão externa com cabos totalmente substituíveis. Como a construção por balanços sucessivos exigia que parte da protensão fosse interna, a solução encontrada foi posicioná-los acima da seção transversal.

As pontes Stolmasundet e Raftsundet na Noruega possuem vãos de 301 e 298 $\mathrm{m}$ respectivamente, que são os recordes atuais para vigas retas de concreto, ambas construídas pelo método dos balanços sucessivos.

\subsection{PONTES ESTAIADAS}

\subsubsection{Breve histórico}

A idéia de suportar um vão por meio de cabos ou correntes que partem de uma torre de sustentação é muito antiga. Os egípcios, por exemplo, já utilizavam este conceito quando projetavam suas embarcações. Indícios arqueológicos mostram que os índios americanos construíam passarelas pênseis de madeira. Pontes pênseis de ferro, construídas nas montanhas do Tibet, estão em registros imperiais chineses de 65 D.C. (WITTFOHT, 1984).

A mais antiga experiência é datada de 1784, quando um carpinteiro alemão, Immanuel Löscher, projetou uma ponte de madeira com tirantes ancorados em uma torre (Figura 2.8). Em 1821, o arquiteto francês Poyet sugeriu utilizar barras de aço suspendidas por mastros de grande altura (MATHIVAT, 1980).

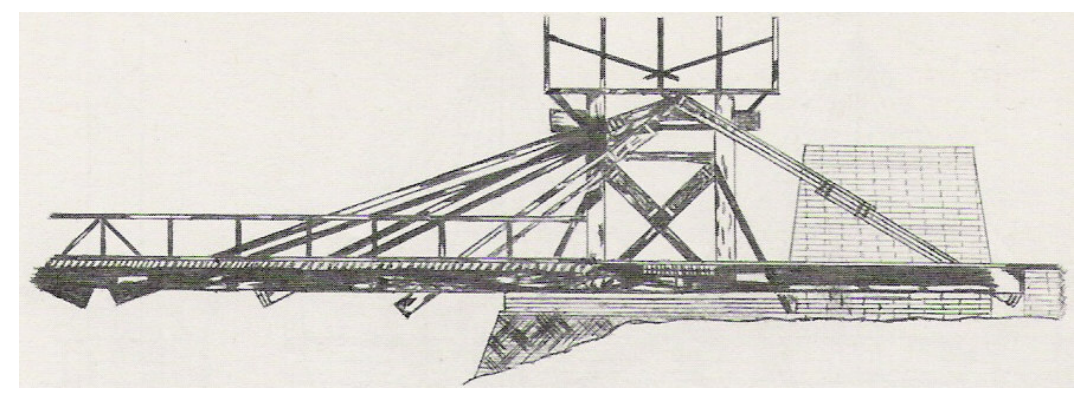

Figura 2.8 - Ponte projetada por Löscher, Alemanha em 1784 (POLDONY; SCALZI, 1976). 
Contudo, o colapso de algumas pontes, como as construídas sobre os rios Tweed e Saale, no inicio do século XIX, fez com que a idéia fosse praticamente abandonada. Devido ao comportamento satisfatório de algumas aplicações, J. Roebling introduziu alguns estais inclinados no projeto de uma ponte pênsil em Niagara, nos Estados Unidos, com o intuito de diminuir a deformabilidade da estrutura.

Em 1883, foi construída, em Nova York, uma das mais notáveis pontes suportadas por cabos: a famosa ponte Brooklyn, com um vão central de 486,50 m e um comprimento total de 1059,90 m. Esta obra é considerada por vários autores como a primeira grande obra de arte, na qual os estais ocupam um papel importante, suportando quase a totalidade das cargas permanentes. Ela foi projetada por $\mathrm{J}$. Roebling, que utilizou os mesmos princípios de dimensionamento da ponte de Niagara, onde o trecho central é suportado pelo cabo parabólico e os estais atuam principalmente na vizinhança das torres (TORNERI, 2002).

Em 1925, Eduardo Torroja construiu a ponte do aqueduto de Tempul. Os estais foram empregados para poder suprimir os pilares intermediários que não puderam ser construídos devido às condições locais.

O desenvolvimento das pontes estaiadas modernas é atribuído ao engenheiro alemão Franz Dischinger que introduziu estais protendidos no projeto da ponte sobre o rio Elbe em 1938. Ele publicou trabalhos onde propôs o uso de aço de alta resistência, submetido à elevada tensão, de modo a reduzir a deformabilidade da ponte e minimizar a perda de rigidez devido à curvatura dos cabos.

Houve um impressionante desenvolvimento das pontes estaiadas após a Segunda Guerra Mundial. Várias pontes foram destruídas na Europa, que, após os conflitos, precisou ser reconstruída. O país que teve um papel fundamental neste desenvolvimento foi a Alemanha que depois foi seguida por todo o mundo.

A primeira ponte estaiada moderna (Figura 2.9) foi construída sobre o canal Donzère na França em 1952.

Apesar desse fato, a obra que deu inicio ao desenvolvimento das pontes estaiadas foi a ponte metálica Strömsund na Suécia com vão principal de $182 \mathrm{~m}$ sob a influência de Dischinger. É interessante ressaltar que apesar de ter sido construída depois da ponte sobre o canal Donzère, é comum encontrar na literatura a ponte Strömsund como sendo a primeira ponte estaiada moderna. 


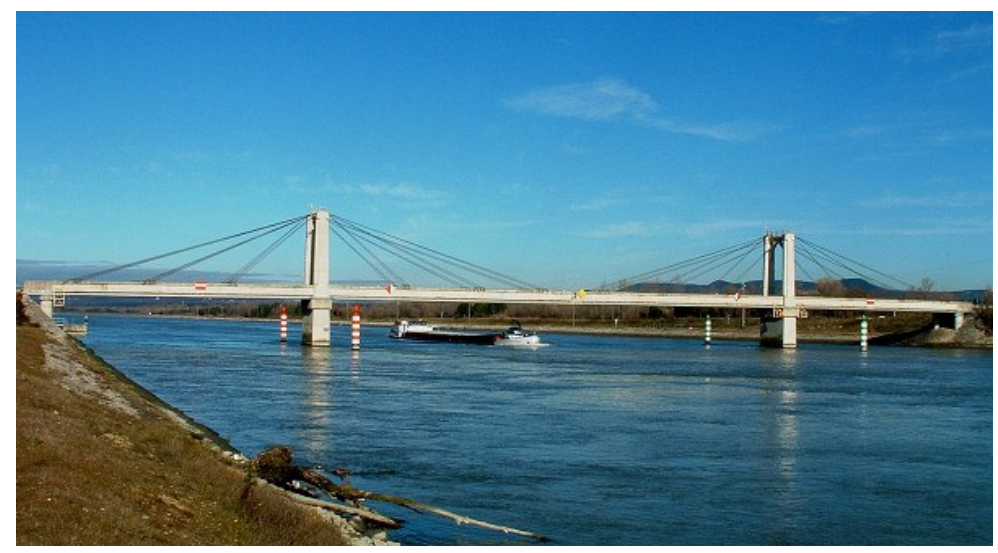

Figura 2.9 - Ponte estaiada de concreto armado sobre o canal Donzère (vão central de 81 m, 1952) na França. Foto: Nicolas Janberg (www.structurae.net).

Após ambas as experiências, foi construída a primeira ponte Alemã. A Theodor Heuss (1956) com vão principal de $260 \mathrm{~m}$ que faz parte da família de pontes estaiadas sobre o rio Reno na cidade de Düsseldorf. As outras são: a Knie (1969) com vão de 320 m e a Oberkassel (1973) com vão de 258 m. Todas possuem tabuleiros metálicos e configuração dos estais em harpa.

Em 1962, Ricardo Morandi projetou a famosa ponte sobre o lago Maracaibo, na Venezuela. As idéias aplicadas nessa obra eram bastante inovadoras e muito diferentes das construções até o momento. A torre é extremamente rígida e na forma de um $\mathrm{V}$ invertido, com um par de estais que suportam o tabuleiro. A parte central consiste em seis torres e cinco vãos principais de $235 \mathrm{~m}$. O método de construção desta ponte foi a maior realização técnica da época (VIRLOGEUX, 2001).

Morandi construiu, ainda, várias pontes com o mesmo princípio, porém modificou o processo em cada nova realização (CHO, 2000). As principais são:

O viaduto Polcevera na Itália (1967), com três torres e dois vãos principais de $280 \mathrm{~m}$;

A ponte Wadi-Kuf na Líbia (1971), com duas torres e vão principal de $281 \mathrm{~m}$.

Um marco no desenvolvimento moderno das pontes estaiadas foi a construção, em 1967, da ponte Friedrich Ebert em Bonn. O projeto de Helmut Homberg possui vão central de $280 \mathrm{~m}$ e utilizou pela primeira vez múltiplos estais. 
A ponte Pasco-Kennewick (vão central de 300 m, 1978) foi a primeira ponte com suspensão total. Nesta concepção, os estais suportam o tabuleiro ao longo de toda a sua extensão, inclusive próximo às torres (TORNERI, 2002).

Um passo adiante foi o conceito de pontes estaiadas com tabuleiros flexíveis, inventado por Ulrich Finsterwalder e Fritz Leonhardt e desenvolvido por René Walther na construção da ponte Dieppoldsau na Suécia (VIRLOGEUX, 2001). Esta ponte possui um vão principal de $97 \mathrm{~m}$ e o tabuleiro é composto por uma laje de concreto com $55 \mathrm{~cm}$ de espessura.

A ponte da Normandia (figura 2.10), na França, pode ser considerada como o maior salto neste campo e a última grande evolução até o momento. A estrutura é híbrida, sendo os vãos de acesso e a região do vão central próxima à torre em concreto e o trecho central em seção celular metálica ortotrópica. A altura da torre (trecho acima do tabuleiro) tem em torno de $160 \mathrm{~m}$ e a altura do tabuleiro é de $3 \mathrm{~m}$.

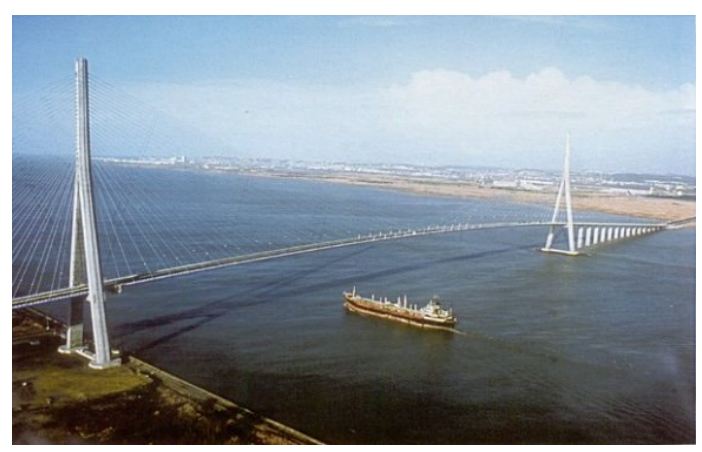

Figura 2.10 - Ponte da Normandia, França (1994).

Atualmente, o recorde de vão é da ponte Tatara (vão de 890m, 1999) no Japão que possui estrutura similar à da Normandia.

\subsubsection{Análise da evolução das pontes estaiadas e suas características}

Podemos dividir o desenvolvimento moderno das pontes estaiadas em duas gerações. A primeira é caracterizada por um pequeno número de cabos bastante espaçados. Os tabuleiros são rígidos devido à necessidade de resistir aos elevados momentos fletores entre os pontos de ancoragem. No entanto, os custos elevados de construção tornam este tipo de obra impraticável nos dias atuais. Alguns exemplos 
são as pontes sobre o canal Donzère (Figura 2.9), a Strömsund e a família de pontes sobre o rio Reno.

A segunda geração tem como característica o emprego de múltiplos estais, pouco espaçados. Os tabuleiros são flexíveis e possuem um comportamento análogo ao de viga sobre apoios elásticos. A montagem dos tirantes e do tabuleiro é simples e a construção por balanços sucessivos é altamente recomendada, inclusive do ponto de vista econômico.

Adicionalmente, com intuito de reduzir os deslocamentos no topo da torre e a sua rigidez, utilizam-se estais de ancoragem (figura 2.11) que têm um importante papel no comportamento estrutural da ponte e sofrem uma flutuação de tensão muito alta ao longo de sua vida útil, sendo necessário tomar precauções quanto aos efeitos de fadiga.
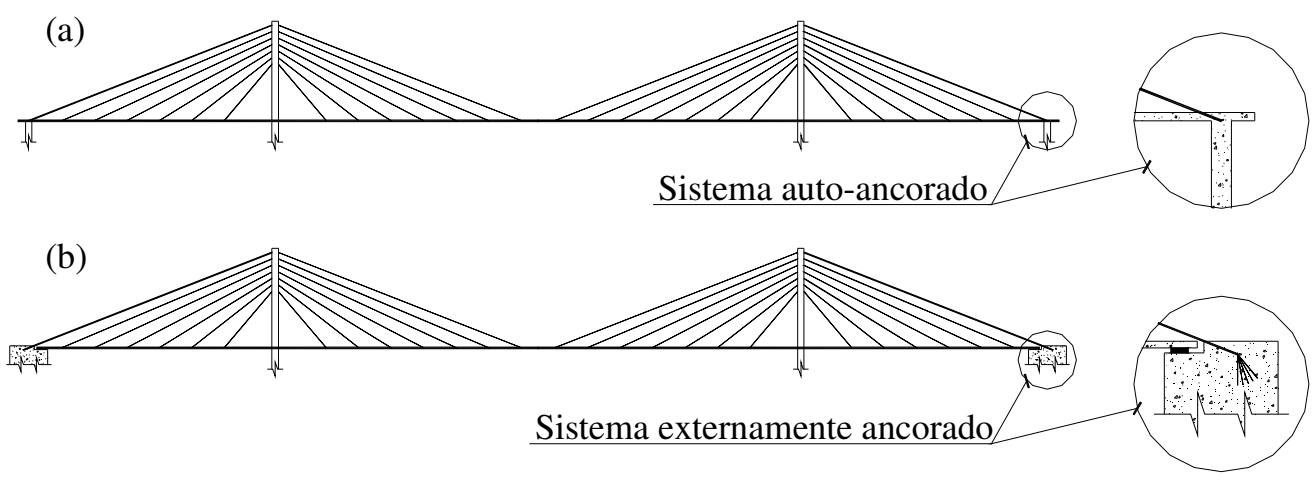

Figura 2.11 - Sistema-auto ancorado (a) e externamente ancorado (b).

Alguns autores dividem o desenvolvimento em três grupos, sendo que a ultima geração é dividida em duas e o tipo de suspensão é o parâmetro de diferenciação adotado. Sendo a segunda geração as pontes com suspensão "parcial" e a terceira as com suspensão total.

\subsubsection{Configuração do sistema de cabo}

A configuração dos estais é um dos itens fundamentais no projeto de uma ponte estaiada. Isso, de fato, influencia não apenas o comportamento estrutural, mas também o método de construção e a sua economia (WALTHER et al., 1999). 


\subsubsection{Sistema longitudinal dos cabos}

Os sistemas longitudinais (figura 2.12) comumente utilizados são: em leque, no qual os cabos convergem no topo da torre, em harpa, no qual os cabos são paralelos, e em semi-harpa que é uma solução intermediária.

(a)

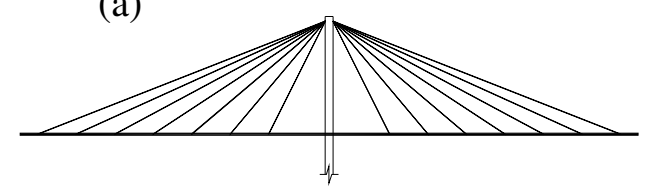

(b)
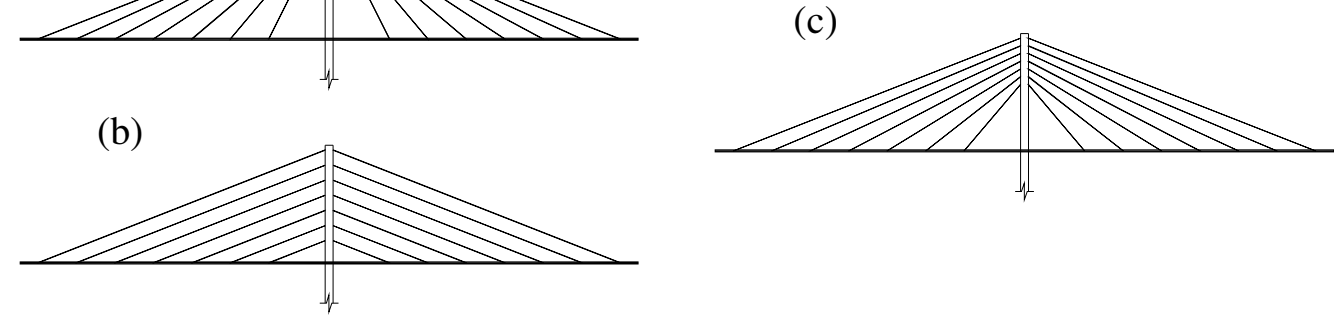

Figura 2.12 - Disposição longitudinal dos cabos: (a) leque, (b) harpa e (c) semiharpa.

O sistema em harpa é o mais atrativo esteticamente, contudo é o menos eficiente em termos de economia e comportamento estrutural. Entretanto, o fato dos cabos serem paralelos simplifica as ancoragens em ambos os extremos.

O sistema em leque é o mais eficiente, uma vez que os estais têm maiores inclinações. WALTHER et al. (1999) indica algumas vantagens que são:

$>\mathrm{O}$ peso total dos cabos é substancialmente menor do que no sistema em harpa;

$>$ A força horizontal introduzida no tabuleiro pelos cabos é menor;

$>$ Os momentos longitudinais nas torres são reduzidos, uma vez que a componente desequilibrada do esforço horizontal pode ser transferida diretamente para o cabo de ancoragem;

$>$ Os deslocamentos da torre e do tabuleiro são reduzidos pelos mesmos motivos que o item anterior.

No entanto, uma desvantagem é que as ancoragens nas torres são mais difíceis e custosas, sendo que um modo de contornar este problema é utilizar o sistema em semi-harpa, onde as ancoragens ficam mais afastadas. 
A escolha da disposição longitudinal dos cabos tem que levar em conta, ainda, as condições topográficas e os vãos necessários. É recomendável sempre projetar o vão lateral menor ou igual à metade do central. Isso se deve ao fato de que o alívio de tensão nos estais de ancoragem é menor, sendo muitas vezes recomendável utilizar disposições assimétricas de cabos ou pilares intermediários que aumentam o numero destes estais de ancoragem e reduzem os deslocamentos nos cabos adjacentes.

Se os comprimentos dos vãos são fixados desde o inicio e a relação mais favorável entre eles não pode ser escolhida, o alivio da tensão nos cabos do vão principal, devido à carregamentos variáveis, deve ser prevenido por meios adicionais. Em pontes de vãos curtos pode ser suficiente aumentar a rigidez à flexão do tabuleiro. Contudo, qualquer transferência de carga dos cabos para o tabuleiro reduz a eficiência global do sistema (MENN, 1990).

Em pontes com pouco estais, como as primeiras pontes estaiadas construídas, a grande rigidez do tabuleiro evita um grande alívio do cabo de ancoragem sob efeito da carga variável no vão lateral, uma vez que uma parcela da carga é transportada pela flexão do tabuleiro sem ser suspensa. Essa característica é similar às pontes com protensão no extradorso.

\subsubsection{Sistema transversal dos cabos}

As disposições transversais são, normalmente, de dois tipos: um único plano central de cabos (suspensão central) e dois planos de cabos posicionados externamente à largura útil da ponte ou entre a calçada e a pista (suspensão lateral).

A suspensão central é a melhor esteticamente, pois evita o cruzamento visual dos cabos. No entanto, não é a melhor solução sob o ponto de vista estático. Os momentos torsores gerados por cargas excêntricas na seção exigem uma elevada rigidez à torção. Como conseqüência disso, há um aumento da rigidez à flexão que normalmente não é necessária, principalmente em pontes com estais pouco espaçados.

O plano central de cabos permite o uso de seções unicelulares clássicas que é conveniente para pontes largas (REIS; PEREIRA, 1994). A utilização de apenas uma 
célula torna necessário utilizar elementos estruturais inclinados para o equilíbrio das forças introduzidas pelos estais. Outra possibilidade é utilizar uma seção bicelular com a alma central coincidindo com o plano de cabos (fig. 2.13).

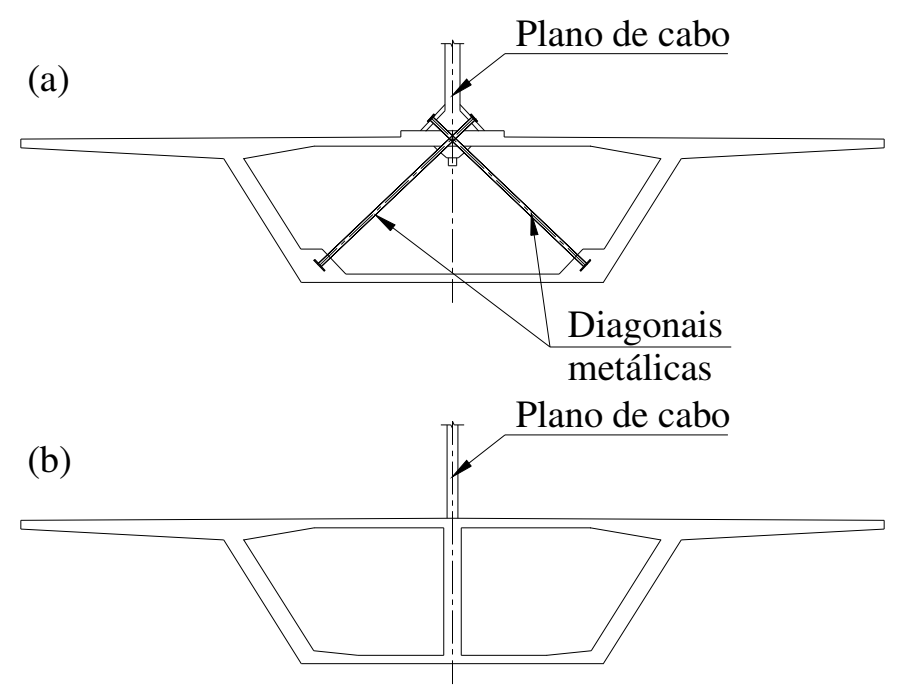

Figura 2.13 - Exemplos de seção transversal para a suspensão central: (a) seção unicelular e (b) seção bicelular.

No caso de seções bicelulares, a solicitação transversal será muito grande sem meios adicionais como transversinas ou tirantes inclinados, sendo que a utilização de transversinas parece ser menos complicada.

Na suspensão lateral, o equilíbrio dos momentos torsores pode ser realizado pelo sistema de cabos a tração e pela flexão transversal da estrutura, podendo a seção transversal, em alguns casos, ter rigidez torsional desprezível (figura 2.14).

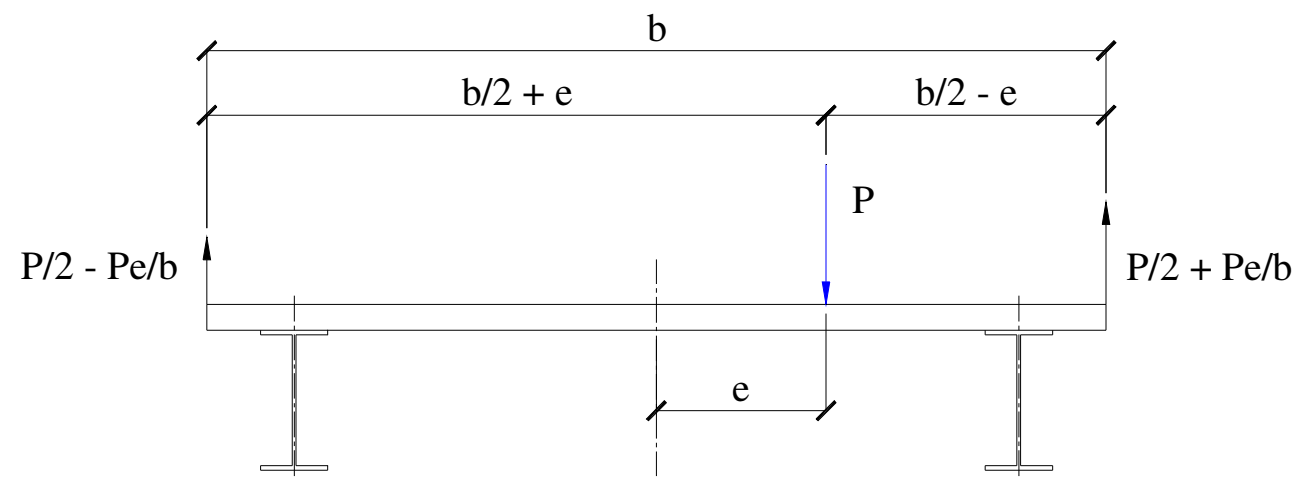

Figura 2.14 - Equilíbrio do momento torsor, provocado pela força $\mathrm{P}$, através de suspensão lateral em tabuleiro com rigidez a torção desprezível (GIMSING, 1983). 
A suspensão lateral melhora a estabilidade aerodinâmica das pontes estaiadas, aumentando a rigidez à torção da estrutura, principalmente no caso de cabos inclinados partindo de uma torre em "A", que distribui melhor os esforços.

\subsubsection{Sistema de cabos em múltiplos vãos}

No caso específico das pontes estaiadas de três vãos, o carregamento do vão central produz deslocamentos verticais descendentes que aumentam as tensões nos estais centrais, movendo a torre no sentido do vão carregado (figura 2.15). Essa configuração deformada da ponte gera uma pequena variação das tensões nos estais laterais (devido aos deslocamentos ascendentes no vão lateral), exceto nos cabos extremos, que, por estarem ancorados, são sujeitos à alta variação de tensão. Esses estais de ancoragem são responsáveis pelo controle dos deslocamentos da torre, bem como do tabuleiro, uma vez que equilibram praticamente toda a componente horizontal provocada pela variação de tensão dos estais centrais.

a) Configuração indeformada

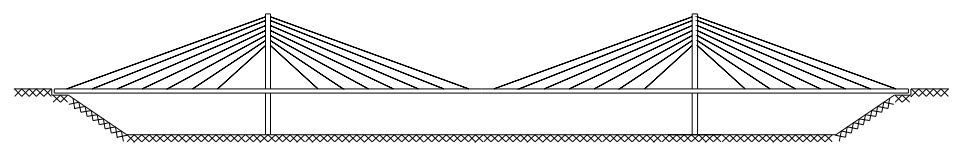

b) Configuração deformada para o carregamento no vão central

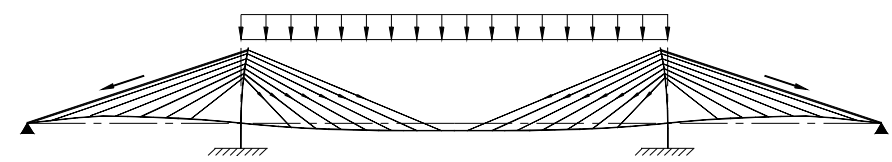

c) Configuração deformada para o carregamento em um vão lateral

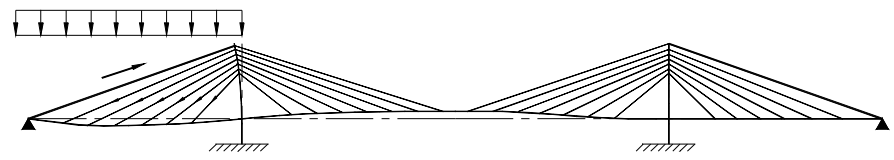

Figura 2.15 - Comportamento estrutural de uma ponte estaiada com três vãos (adaptado de VIRLOGEUX, 2001).

No caso de pontes com sistema de cabos em múltiplos, o comportamento estrutural é diferente em relação àquelas que possuem dois ou três vãos. A ausência de pilares intermediários que exclui o uso de cabos de ancoragem faz com que os deslocamentos globais gerados por cargas assimétricas só possam ser controlados pelas rigidezes do tabuleiro e da torre (figura 2.16). 
a) Configuração indeformada

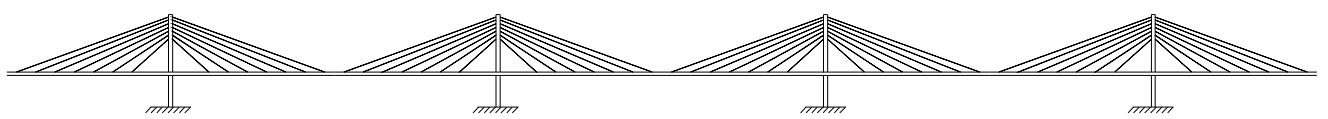

b) Configuração deformada para o carregamento no vão central

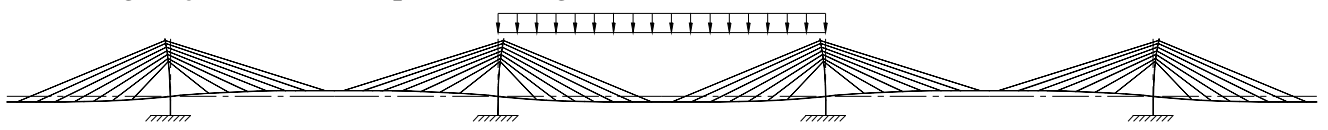

c) Configuração deformada para o carregamento no vão lateral

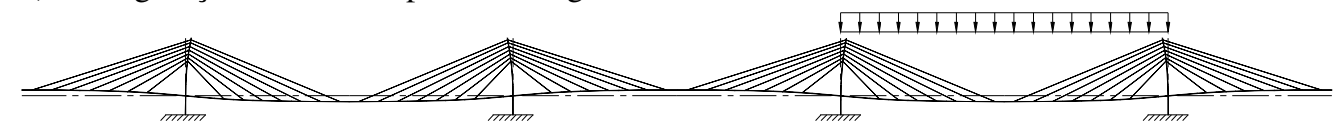

Figura 2.16 - Deformação de pontes estaiadas com múltiplos vãos para carregamentos assimétricos (adaptado de VIRLOGEUX, 2001).

VIRLOGEUX (2001) faz uma análise considerando torres e tabuleiros similares àqueles comumente utilizados em pontes de três vãos. As deformações para cargas assimétricas são tão grandes que resultam em momentos fletores elevados tanto no tabuleiro, como na torre, além disso, ao carregar o vão adjacente o sentido destes esforços se inverte.

Algumas soluções são possíveis, sendo a maioria delas esteticamente pobres. A primeira (figura 2.17, item a) e mais lógica, porém, nem sempre possível de se aplicar, seria construir pilares intermediários que dividem os vãos e reduzem os seus deslocamentos, além de permitir tirantes de ancoragem. A segunda (figura 2.17, item b) é inspirada nas pontes penseis e utiliza cabos ligando o topo das torres. Outra solução é adicionar cabos ligando o topo de uma torre à outra adjacente no nível do tabuleiro (figura 2.17, item c).

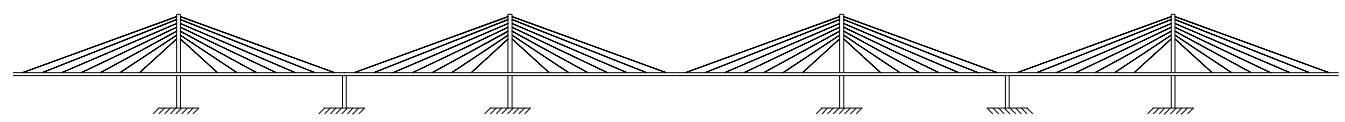

a) Pilares intermediários

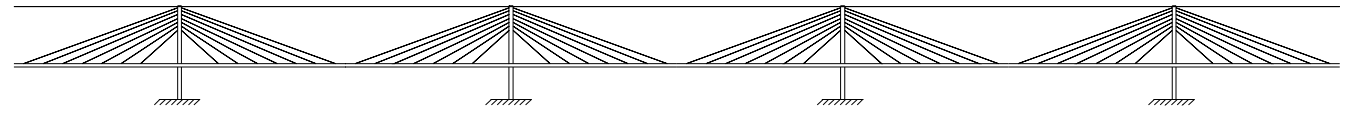

b) Cabos horizontais ligando o topo das torres

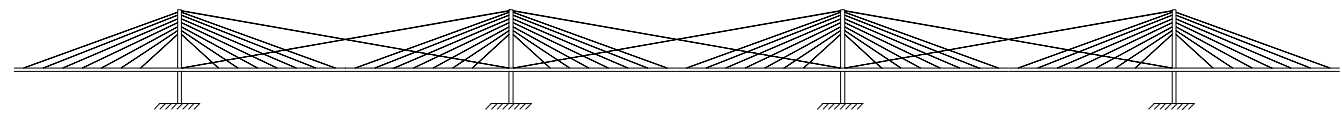

c) Cabos inclinados ligando o topo de uma torre a uma adjacente no nivel do tabuleiro

Figura 2.17 - Soluções possíveis para pontes com cabos em múltiplos vãos (adaptado de VIRLOGEUX, 2001). 
Outra solução é elevar a rigidez dos elementos que compõem a estrutura, permitindo três possibilidades (VIRLOGEUX, 2001):

> Tabuleiros suficientemente rígidos para resistir aos momentos fletores induzidos pela carga variável. Esta solução é aplicável em pontes com vãos curtos, pois a transferência de carga dos cabos para o tabuleiro reduz a eficiência global da ponte.

$>$ Torres extremamente rígidas, assim como na ponte sobre o lago Maracaibo, que permite a utilização de tabuleiros flexíveis.

$>$ Distribuir a rigidez entre o tabuleiro e a torre, sendo esta a solução mais elegante.

De qualquer forma, elevar a rigidez da torre ou do tabuleiro eleva o custo da construção. Somando a isto o aspecto estético das outras soluções, as pontes com cabos em múltiplos vãos não têm tido muitas aplicações práticas. Alguns exemplos são: a ponte Ting Kau, o viaduto Arena (1993) e o viaduto Milau (França, 2004) que tem sido admirado pela altura dos pilares que chegam a $245 \mathrm{~m}$.

\subsection{PONTES SUPORTADAS POR CABOS PROTENDIDOS INFERIORES}

As pontes com cabos protendidos inferiores consistem em construir escoras no tabuleiro que é suportado por cabos protendidos de forma a criar apoios flexíveis intermediários. Esse esquema estrutural é parecido com as pontes com protensão no extradorso, pois o transporte das cargas sobre o tabuleiro até os apoios também é realizado com a colaboração da viga à flexão e do sistema de cabos à tração.

A primeira ponte construída desta forma foi a Weitigen (1978) que cruza o vale Neckar na Alemanha. Por razões geológicas, pilares não puderam ser construídos no declive arborizado do vale. Por isso, vãos extremos longos (263 m, lado sul) foram necessários, onde uma viga celular foi escorada por nervuras metálicas sobre estais (LEONHARDT, 1982).

Em 1989, J. Schlaich repete a aplicação de cabos inferiores, em uma rara e interessante combinação com estais superiores para a ponte Obere Argen (figura 
2.18) na Argentina. O vão extremo com $258 \mathrm{~m}$ utiliza cabos superiores e inferiores com a mesma lei de variação dos momentos fletores da ponte.

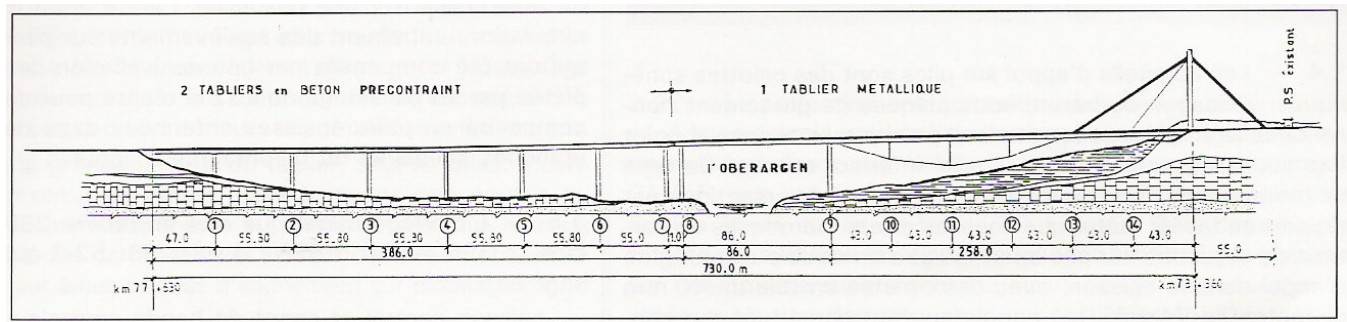

Figura 2.18 - Esquema da ponte Obere Argen na Argentina, 1989 (CAZET, 1990).

Uma vantagem deste tipo de ponte é a possibilidade de utilização em vãos isostáticos, assim como na ponte The Truc de la Fare em 1993 (figura 2.19) na França. O tabuleiro consiste em uma laje (vão de $53 \mathrm{~m}$ ) com três escoras metálicas em forma de $\mathrm{V}$, sendo que a central tem $5 \mathrm{~m}$ de altura e as laterais $3,5 \mathrm{~m}$. A variação de tensão nos cabos protendidos para a carga variável máxima foi de $112 \mathrm{MPa}$, que é da mesma ordem de grandeza dos estais das pontes estaiadas.

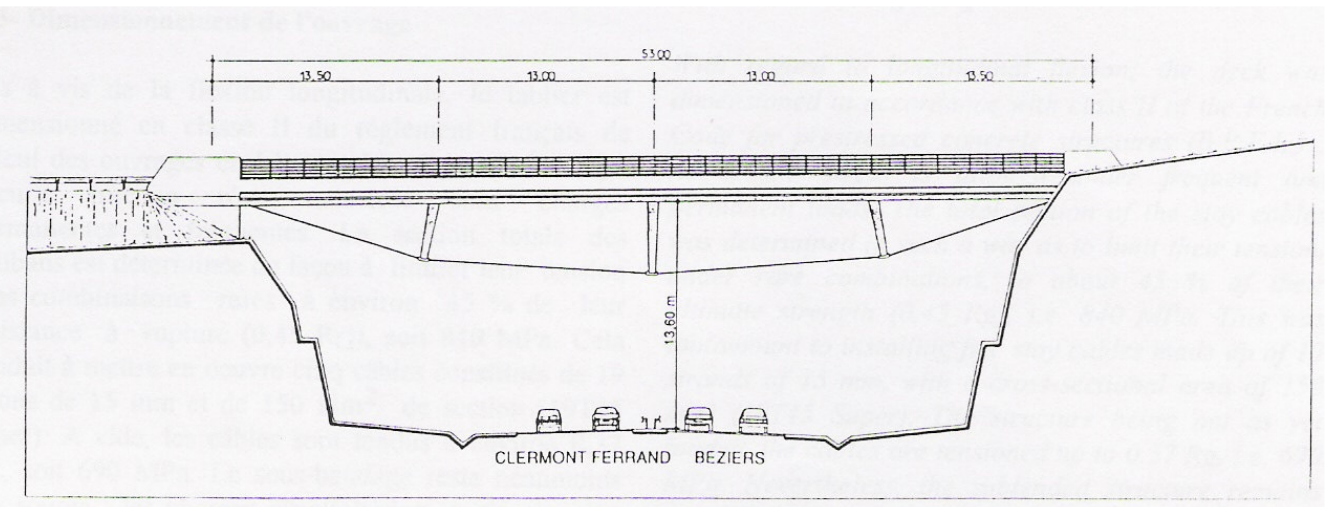

Figura 2.19 - Ponte The Truc De La Fare, França (VIRLOGEUX et al. 1994).

Essas três pontes podem ser associadas às pontes estaiadas de primeira geração, pois possuem tabuleiros com rigidez suficiente para resistir aos momentos entre as escoras ou entre escora e apoio e por possuírem sistemas de protensão tecnologicamente similares aos estais.

A utilização de uma protensão extradorsal inferior foi aplicada pela primeira vez de uma maneira sistemática na ponte Osormort (figura 2.20), de $504 \mathrm{~m}$ de comprimento e vãos de $40 \mathrm{~m}$. A oscilação da tensão nos tirantes inferiores, para 
sobrecarga máxima, não passava de $8 \mathrm{Kg} / \mathrm{mm}^{2}$ (80 MPa), o que permitiu o uso de ancoragens correspondentes a protensão externa (MANTEROLA, 1997). As escoras inferiores possuem $5 \mathrm{~m}$ de comprimento $(\mathrm{H}=\mathrm{L} / 8)$.

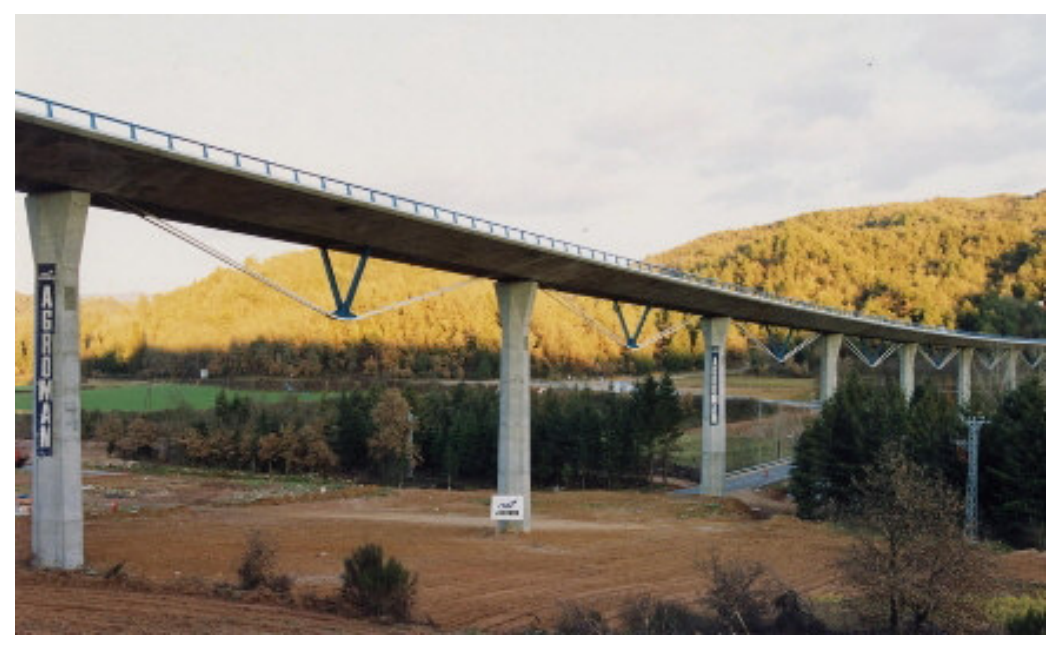

Figura 2.20 - Ponte Osormort na Espanha (1995).

\subsection{PONTES COM PROTENSÃO NO EXTRADORSO}

As pontes com protensão no extradorso utilizam cabos tecnologicamente similares à protensão externa, situados acima do tabuleiro e que são desviados ou ancorados em pequenas torres.

O emprego de tabuleiros mais rígidos e de menores alturas de torre em relação às pontes estaiadas reduz a eficiência global do sistema, no entanto, isto se justifica, devido às seguintes razões:

$>\mathrm{O}$ aumento do consumo de aço, devido à menor inclinação dos cabos, pode ser compensado, em parte, pela utilização de uma tensão admissível maior;

A construção da torre é mais simples e tem menos custo;

A utilização de sistemas de protensão similares à protensão externa reduz, consideravelmente, o custo das ancoragens em relação às pontes estaiadas. 
MATHIVAT (1988) sugere que essa tipologia de ponte tenha altura constante no tabuleiro, com valores ótimos entre L/35 e L/30, e sugere também o valor da altura da torre em $\mathrm{L} / 15$, sendo $\mathrm{L}$ o comprimento do vão principal.

As obras existentes (tabela 2.2) possuem, em sua maioria, altura variável no tabuleiro. As obras de concreto, normalmente, têm altura em torno de L/35 nos apoios intermediários e L/55 no meio do vão. A altura da torre varia entre L/14 e L/8, exceto para as pontes Miyakoda e Matakina que possuem dois vãos e características não usuais para este tipo de estrutura.

Observar que nas pontes estaiadas a altura do tabuleiro varia entre L/120 e $\mathrm{L} / 80$ (sendo usual o valor L/100) e a altura da torre varia entre L/5 e L/4.

Tabela 2.2 - Algumas pontes com protensão no extradorso construídas até 2001 e as duas pontes brasileiras.

\begin{tabular}{|c|c|c|c|c|c|c|c|c|c|}
\hline Ponte & $\begin{array}{c}\text { Material } \\
\text { estrutural }\end{array}$ & Vãos & $\begin{array}{c}\text { Comp. } \\
\text { Total }\end{array}$ & $\begin{array}{c}\text { Vão } \\
\text { máximo }\end{array}$ & $\begin{array}{c}\text { Altura } \\
\text { da torre }\end{array}$ & H/L & $\begin{array}{c}\text { Altura do } \\
\text { tabuleiro }\end{array}$ & h/L & Ano \\
\hline $\begin{array}{c}\text { Odawara } \\
\text { Blueway }\end{array}$ & Concreto & 3 & 270 & 122 & 10,7 & $1 / 11$ & $3,5 \sim 2,2$ & $1 / 35 \sim 1 / 55$ & 1994 \\
\hline $\begin{array}{c}\text { Yashiro } \\
\text { (ponte sul) }\end{array}$ & Concreto & 4 & 340 & 105 & 12 & $1 / 9$ & 2,5 & $1 / 42$ & 1996 \\
\hline $\begin{array}{c}\text { Yashiro } \\
\text { (ponte norte) }\end{array}$ & Concreto & 3 & 200 & 90 & 10 & $1 / 9$ & 2,5 & $1 / 36$ & 1996 \\
\hline Tsukuhara & Concreto & 3 & 323 & 180 & 16 & $1 / 11$ & $5,5 \sim 3,0$ & $1 / 33 \sim 1 / 60$ & 1998 \\
\hline $\begin{array}{c}\text { Second } \\
\text { Mandaue }\end{array}$ & Concreto & 3 & 410 & 185 & 18,2 & $1 / 10$ & $4,9 \sim 3,1$ & $1 / 38 \sim 1 / 60$ & 1999 \\
\hline Matakina & Concreto & 2 & 200 & 109,3 & 26,4 & $1 / 4$ & $6,0 \sim 3,5$ & $1 / 18 \sim 1 / 31$ & 2000 \\
\hline Ibi River & $\begin{array}{c}\text { Mista } \\
\text { Conc./Aço }\end{array}$ & 5 & 1145 & 275 & 30 & $1 / 9$ & $7,0 \sim 4,0$ & $1 / 39 \sim 1 / 69$ & 2001 \\
\hline Kiso River & $\begin{array}{c}\text { Mista } \\
\text { Conc./Aço }\end{array}$ & 6 & 1397 & 271,5 & 30 & $1 / 9$ & $7,0 \sim 4,0$ & $1 / 39 \sim 1 / 68$ & 2001 \\
\hline $\begin{array}{c}\text { Japan Palau } \\
\text { Friendship }\end{array}$ & $\begin{array}{c}\text { Mista } \\
\text { Conc./Aço }\end{array}$ & 3 & 413 & 247 & 27 & $1 / 9$ & $7,0 \sim 3,5$ & $1 / 35 \sim 1 / 71$ & 2001 \\
\hline Shikari & Concreto & 5 & 610 & 140 & 10 & $1 / 14$ & $6,0 \sim 3,0$ & $1 / 23 \sim 1 / 47$ & 2001 \\
\hline Miyakoda & Concreto & 2 & 268 & 133 & 20 & $1 / 7$ & $6,5 \sim 4,0$ & $1 / 20 \sim 1 / 33$ & 2001 \\
\hline $\begin{array}{c}\text { Hozu } \\
\text { 3ante de } \\
\text { Rio Branco }\end{array}$ & Concreto & 6 & 368 & 100 & 10 & $1 / 10$ & 2,8 & $1 / 36$ & 2001 \\
\hline $\begin{array}{l}\text { Integração } \\
\text { Brasil Peru }\end{array}$ & Concreto & 3 & 198 & 90 & 9 & $1 / 8$ & $2,5 \sim 2,0$ & $1 / 36 \sim 1 / 45$ & 2006 \\
\hline $\begin{array}{c}\text { H - Altura da torre } \\
\text { Concto }\end{array}$ & 3 & 240 & 110 & 15 & $1 / 7$ & $3,35 \sim 2,35$ & $1 / 33 \sim 1 / 47$ & 2006 \\
\hline
\end{tabular}


A seguir serão descritas de forma resumida algumas pontes da tabela 2.2.

\subsubsection{Ponte Odawara Blueway}

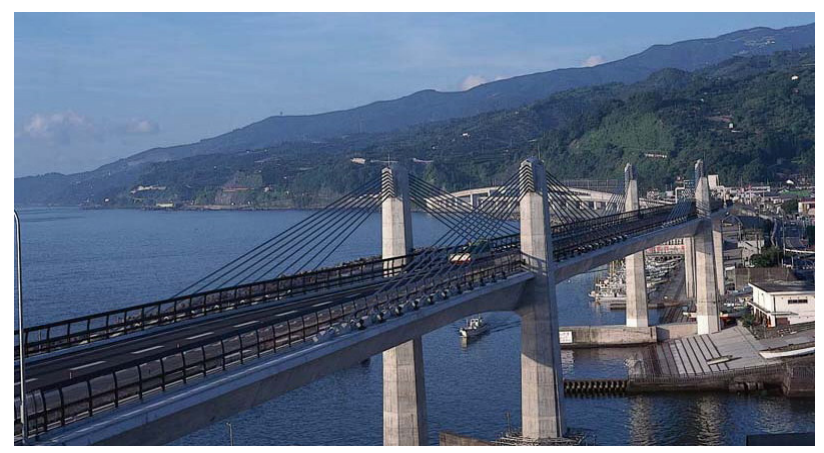

Figura 2.21 - Ponte Odawara Blueway, Japão (1994).

A ponte Odawara Blueway (fig. 2.21) é a primeira construída com protensão no extradorso. Ela possui três vãos de 74, 122 e 74 m, a largura total do tabuleiro é de 15,92 m. A altura da viga é igual a 3,5 m ( L/35) nos apoios intermediários e 2,2 m ( L/55) no meio do vão. A relação entre a altura da torre e o vão principal é de aproximadamente $1 / 12$.

Devido à maior rigidez do tabuleiro associada a uma menor altura da torre, a oscilação da tensão nos cabos protendidos, em virtude das sobrecargas, foram reduzidas em, aproximadamente, um quarto daquelas obtidas nos estais das pontes estaiadas. Por isso, se adotou uma tensão admissível de $60 \%$ da tensão de ruptura do aço.

As ancoragens utilizadas no tabuleiro são as mesmas da protensão externa convencional. Nesta ponte foram introduzidas selas no topo da torre que simplificam os detalhes. Os cabos foram ancorados por fora da sela, com o intuito de não permitir deslizamentos, melhorando assim, o comportamento a fadiga do sistema. A resistência da sela foi confirmada por testes em escala real.

Para suprimir as vibrações induzidas pela chuva nos cabos, foram utilizados amortecedores de borracha na parte inferior de cada tirante. 


\subsubsection{Ponte Tsukuhara}

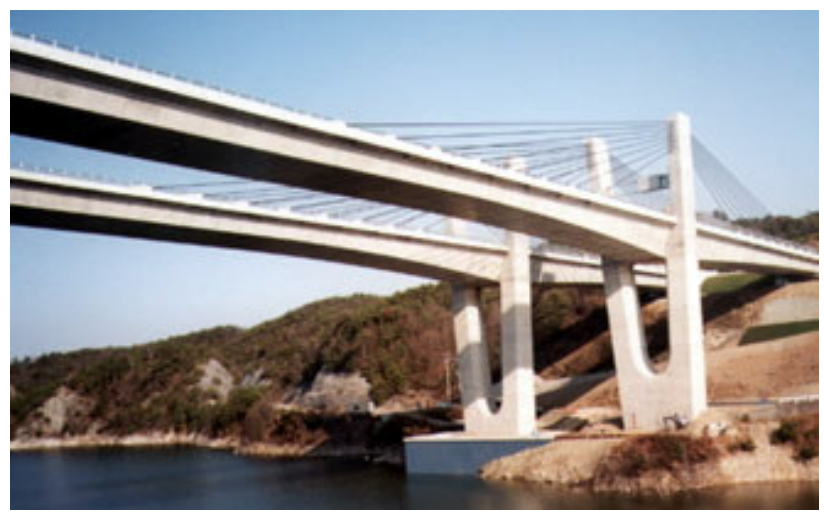

Figura 2.22 - Ponte Tsukuhara, Japão (1998).

A ponte Tsukuhara (fig. 2.22) construída no Japão é uma estrutura em pórtico com três vãos $(65,4 \mathrm{~m}+180 \mathrm{~m}+76,4 \mathrm{~m})$. A relação entre a altura da torre e o vão principal é de aproximadamente 1/12. O tabuleiro consiste em uma viga unicelular com altura de 5,5 m ( L/33) na região das torres e 3,0 m (L/60) no meio do vão e largura efetiva de $9,25 \mathrm{~m}$.

Originalmente, a ponte Tsukuhara foi planejada como uma ponte em arco. No entanto, a tipologia foi modificada por causa do sucesso no Japão da ponte Odawara Blueway e para obter melhor harmonia com uma passarela estaiada adjacente (OGAWA; MATSUDA; KASUGA, 1998).

Doze cabos externos de $19 \phi 15,2 \mathrm{~mm}$ foram utilizados no trecho central para resistir aos momentos fletores. A ponte possui também cabos internos de 12ф12,7 mm, a maioria devido à construção por balanços sucessivos. Além disso, foram empregadas cordoalhas de $28,6 \mathrm{~mm}$ de diâmetro com aderência posterior para protensão transversal da laje superior. Os cabos no extradorso são de $27 \phi 15,2 \mathrm{~mm}$, protegidos contra a corrosão por meio de dupla camada de polietileno.

A máxima flutuação de tensão nos cabos é de $3,7 \mathrm{~kg} / \mathrm{mm}^{2}(\sim 37 \mathrm{MPa})$, o que permite o emprego de uma tensão admissível de sessenta por cento da tensão de ruptura do aço e as ancoragens da protensão externa clássica.

Os pilões (pilar e torre no mesmo elemento estrutural) são em formato de V. Não foram necessárias vigas de travamento devido à pequena altura da torre (trecho acima do tabuleiro) e selas foram utilizadas para simplificar a instalação da 
armadura. Foi necessário utilizar contrapesos dentro da seção celular nos vãos extremos com o intuito de reduzir os momentos fletores nos pilões.

Uma vez que a região em que a ponte foi construída é susceptível a sismos, uma análise estrutural sob tal ação foi realizada.

Uma das vantagens do esquema estrutural com protensão no extradorso em relação às pontes estaiadas é que não foi necessário nenhum ajuste nas forças dos tirantes ao término da construção, ou seja, a protensão de um tirante não modifica (significativamente) a força daqueles já instalados. Isso significa que não foi preciso empregar aparatos especiais para sustentar os macacos hidráulicos, que puderam ser colocados na forma deslizante (OGAWA; MATSUDA; KASUGA, 1998).

\subsubsection{Ponte Second Mandaue - Mactan}

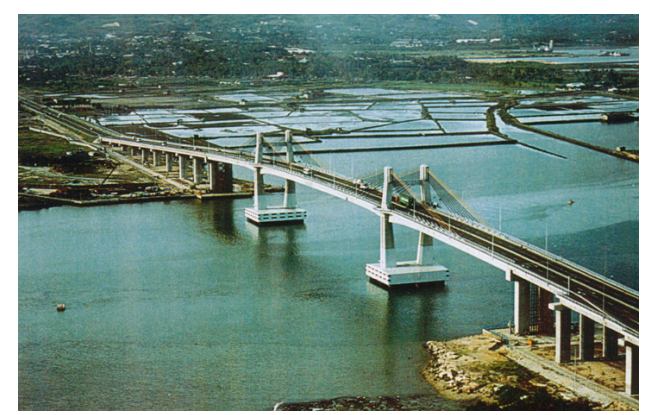

Figura 2.23 - Ponte Second Mandaue - Mactan, Filipinas (1999).

A ponte Second Mandaue - Mactan (figura 2.23) é a ponte de concreto com protensão no extradorso de maior vão livre do mundo. Essa estrutura em viga contínua de três vãos $(111,5 \mathrm{~m}+185,0 \mathrm{~m}+111,5 \mathrm{~m})$ possui altura de torre aproximadamente igual a L/10. A altura do tabuleiro é variável e igual a $5,1 \mathrm{~m}$ ( L/36) nos apoios intermediários e 3,3 m ( L/56) no meio do vão, além de largura total de $21 \mathrm{~m}$.

A tipologia de ponte com protensão no extradorso foi empregada devido à proximidade com o aeroporto internacional de Cebu, o que tornou necessário utilizar torres pequenas.

Os cabos no extradorso consistem de 48 $\$ 15,2 \mathrm{~mm}$ com tripla proteção contra corrosão, revestimento de epóxi, nata de cimento e tubos de polietileno de alta densidade. 


\subsubsection{Pontes Kiso River e Ibi River}

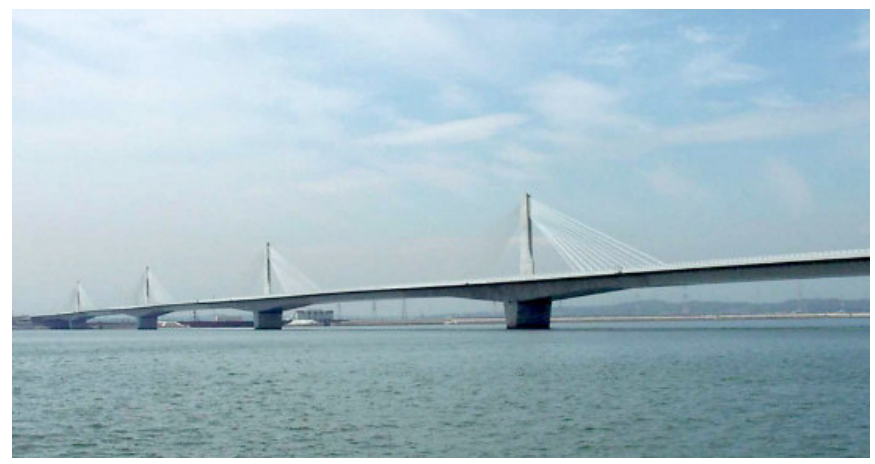

Figura 2.24 - Ponte Kiso River, Japão (2001).

As pontes Ibi River e Kiso River (figura 2.24) são as primeiras aplicações de estruturas mistas associadas à protensão no extradorso. São projetos similares de pontes com sistema de cabos em múltiplos vãos, no qual o trecho central de todos os vãos intermediários consiste em uma seção celular metálica de $100 \mathrm{~m}$ de comprimento, sendo o restante do tabuleiro em seção celular de concreto.

As pontes Ibi River e Kiso River possuem comprimento total de 1397 m (vãos de $154+4 \times 271,5+157$ m) e de 1145 m (vãos de $160+3 \times 275+160$ m), respectivamente. Em ambas, a altura da torre é de $30 \mathrm{~m}$, a do tabuleiro é de $7 \mathrm{~m}$ nos apoios intermediários e de $4 \mathrm{~m}$ no meio do vão e a largura total é de $33 \mathrm{~m}$. O emprego de trechos metálicos reduz o peso da estrutura e permite alcançar vãos comuns às pontes estaiadas.

A construção das seções de concreto foi realizada pelo método dos balanços sucessivos com aduelas pré-moldadas. O peso de cada segmento varia de 300 a 400 toneladas, que foram transportadas por barcaças e suspendidas e montadas em sua posição final. Os trechos metálicos que pesam aproximadamente 2000 toneladas foram içados em apenas uma etapa.

\subsubsection{Terceira ponte sobre o Rio Acre}

A terceira ponte sobre o Rio Acre (figura 2.25) é a primeira construída com protensão no extradorso do Brasil. Ela possui três vãos de 54, 90 e 54 m e a largura total do tabuleiro é de $17,4 \mathrm{~m}$. A obra possui dois planos de cabos (suspensão 
lateral), a altura das torres é de $12 \mathrm{~m}$, sendo que os cabos se posicionam entre 6 e $9 \mathrm{~m}$ acima do tabuleiro.

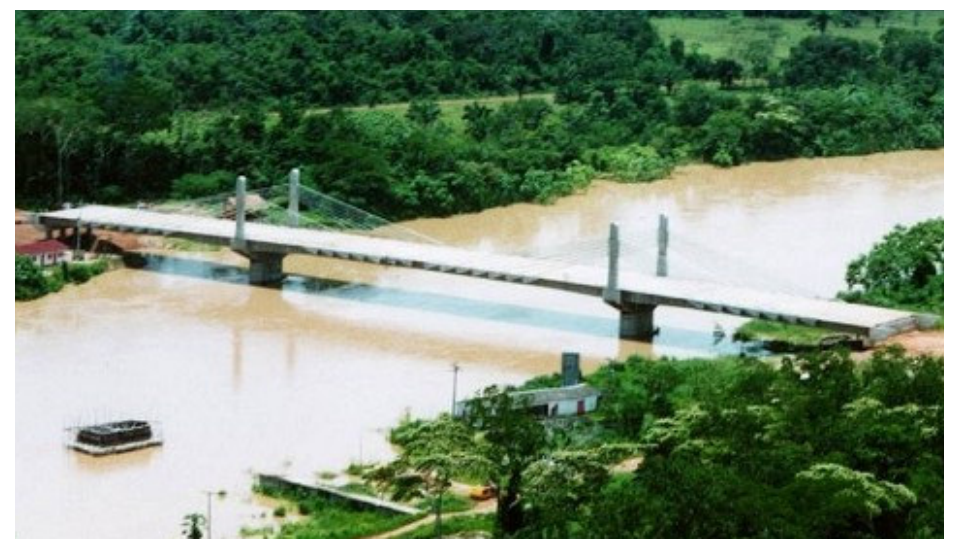

Figura 2.25 - Terceira ponte sobre o Rio Acre, Brasil (2006).

Os tirantes são constituídos de 16 cordoalhas de aço CP176RB e receberam três camadas de proteção contra corrosão: galvanização dos fios a quente, filme de cera de petróleo e revestimento de polietileno de alta densidade.

A altura do tabuleiro varia entre 2,5 m (na região do apoio intermediário) e 2,0 m (na região central do vão) e é formado por duas vigas longitudinais. O espaçamento dos cabos no extradorso é de 3,9 m e foram empregadas transversinas com o mesmo espaçamento. Para melhoria da resistência da seção do apoio intermediário em relação aos momentos negativos, foram adotadas lajes inferiores de $3 \mathrm{~m}$ de largura em cada viga nessa região.

\subsubsection{Ponte da integração Brasil-Peru}

A ponte da integração Brasil-Peru (figura 2.26) transpõe o Rio Acre, ligando os municípios de Assis Brasil do estado do Acre no Brasil e Inãpari no Peru (Ishii et al., 2005). Embora a conclusão da ponte tenha sido realizada após a terceira ponte sobre o Rio Acre, esta foi inaugurada antes, o que a torna, a primeira ponte com protensão no extradorso brasileira. 


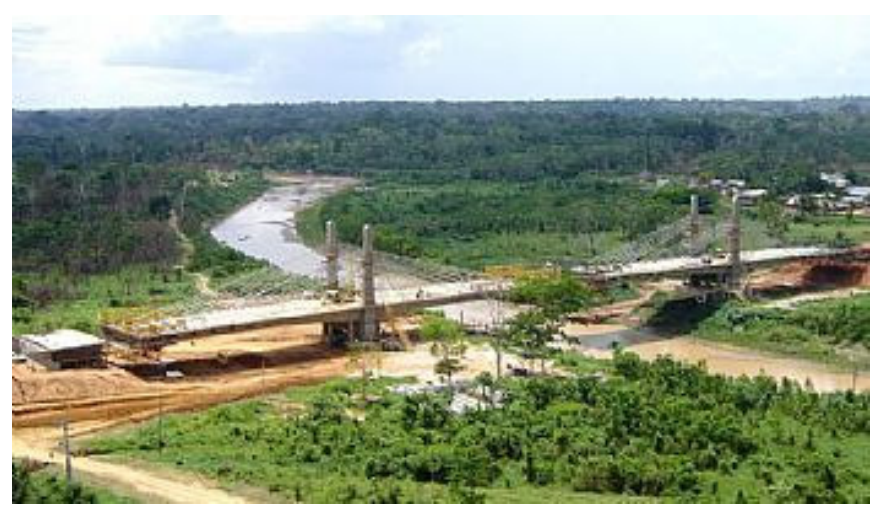

Figura 2.26 - Ponte da integração Brasil - Peru, Brasil (2006).

A ponte possui três vãos de 65,110 e $65 \mathrm{~m}$, largura total de $16,8 \mathrm{~m}$. A obra tem dois planos de cabos, altura de torre igual a 15 m e os tirantes são constituídos de 17 cordoalhas de 15,2 $\mathrm{mm}$ de aço CP176RB.

O tabuleiro é constituído de uma viga celular de concreto com altura variando de 2,35 m ( L/47) no centro do vão principal a 3,35 m ( $\sim \mathrm{L} / 33)$ na região dos apoios intermediários.

\subsubsection{Pontes construídas com algumas características do sistema de protensão no extradorso}

A ponte Kanisawa (1998) construída no Japão é uma estrutura em viga continua de três vãos $(99,275 \mathrm{~m}+180 \mathrm{~m}+99,275 \mathrm{~m})$. A altura da torre é aproximadamente igual a 1/8 do vão central e a altura do tabuleiro varia entre L/60 e $\mathrm{L} / 33$.

Embora as dimensões dessa ponte tenham a mesma ordem de grandeza das pontes na tabela 2.2 e, conseqüentemente, o comportamento estrutural seja similar, a flutuação de tensão nos tirantes é relativamente grande ( 100MPa), o que limitou a tensão admissível em 40\% da resistência última do aço (CHO, 2000). A adoção de sistema de protensão similar ao das pontes estaiadas gera distorções na especificação, o que em nossa opinião é uma combinação ineficiente de ambas.

Outra obra que pode ser encontrada na literatura equivocadamente definida como sendo protendida no extradorso é a ponte Sunniberg na Suíça (figura 2.27). O projeto conceitual é de Christian Menn, que devido às exigências não usuais relativas 
à estética propôs uma ponte estaiada com altura de torre aproximadamente igual a $10 \%$ do vão principal. A estrutura utiliza sistema de cabos em múltiplos vãos com disposição em harpa, o tabuleiro é extremamente flexível e a impossibilidade de ter tirantes de ancoragens intermediários, levou à adoção de pilões extremamente rígidos conectados monoliticamente ao tabuleiro, com o intuito de reduzir os deslocamentos da estrutura que poderiam ser inaceitáveis.

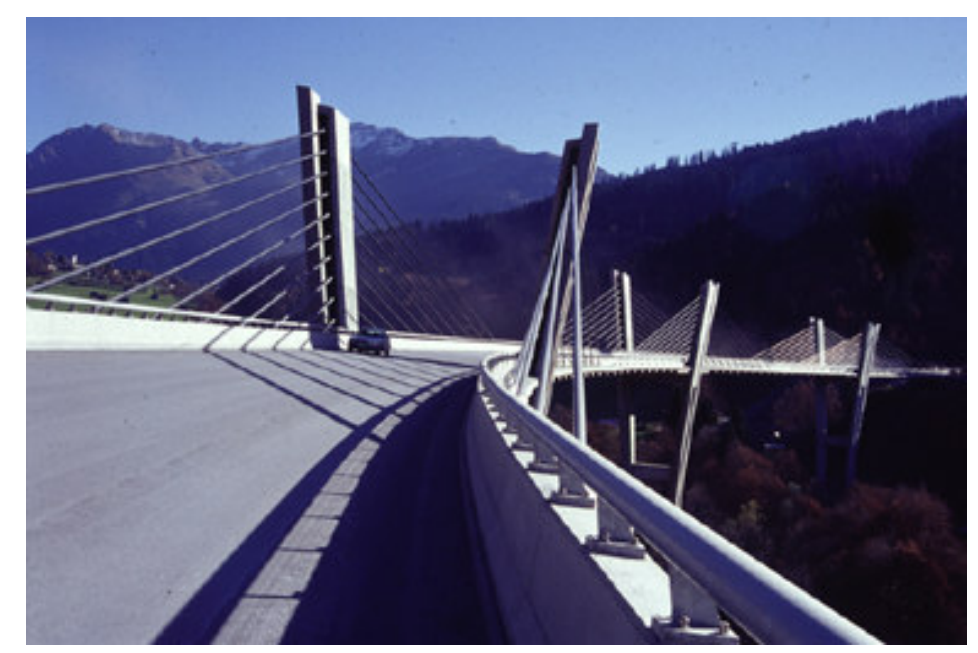

Figura 2.27 - Ponte Sunninberg, Suíça (1998).

\subsubsection{Conclusões sobre as pontes com protensão no extradorso construídas}

Podemos obter algumas conclusões ao estudar as pontes com protensão no extradorso construídas que são:

As pontes de concreto com protensão no extradorso oferecem uma solução econômica para vãos entre 100 e 200 m;

A construção deste tipo de ponte requer o conhecimento das tecnologias empregadas nas pontes de concreto protendido em viga e estaiadas;

$>$ Houve um excepcional crescimento na construção das pontes com protensão no extradorso;

$>$ Devido à alta rigidez à flexão do tabuleiro, o emprego de sistema de cabos em múltiplos vãos não necessita de meios adicionais em relação à 
ponte de três vãos. Adicionalmente, não há necessidade de ajustar a tensão nos tirantes, nem durante a construção, nem ao final da obra, ao contrário do que ocorre nas pontes estaiadas;

$>$ As pontes com protensão no extradorso, assim como ocorre na ponte Second Mandaue - Mactan, são ideais em regiões próximas a aeroportos que necessitam grandes vãos;

$>$ Um dimensionamento adequado dos elementos da ponte permite evitar grandes flutuações de tensão, descartando de forma quase que absoluta o risco de fadiga, tanto no cabo, quanto nas ancoragens, permitindo a utilização da tecnologia da protensão externa;

$>$ A união do conceito da protensão no extradorso em pontes de estrutura mista com a utilização de concreto de alta resistência, tal como ocorre nas pontes Ibi e Kiso River, permitem alcançar vãos das pontes estaiadas convencionais;

Devido a menores inclinações dos cabos na torre é comum a utilização de sela, o que simplifica bastante a armação e permite espaçamentos pequenos dos cabos no topo da torre, gerando uma disposição em leque.

\subsection{COMPORTAMENTO À FADIGA DE CABOS PÓS-TRACIONADOS}

\subsubsection{Generalidades.}

A fadiga de um material é a deterioração progressiva de sua resistência quando o mesmo é submetido a uma serie de ciclos de flutuação de tensão, estando o mesmo em regime elástico. Este fenômeno de deterioração progressiva da propriedade mecânica do material que pode gerar uma ruptura prematura e frágil é conhecido como dano por fadiga.

Em estruturas que utilizam cabos protendidos, a análise da resistência à fadiga é um fator muito importante para a integridade estrutural. Embora em elementos de concreto protendido não seja comum a verificação da fadiga, alguns pesquisadores evidenciaram que a resistência à fadiga de estruturas com protensão parcial ou externa pode ser bastante reduzida. 
Nos últimos anos, diversos comitês e pesquisadores têm se preocupado com especificações e recomendações referentes aos ensaios de resistência à fadiga. Normalmente, tais especificações são produto da extração e ampliação do código alemão (DIN 1073), que por bastante tempo foi a única referência neste assunto. Atualmente, podem-se citar três recomendações que podem auxiliar o engenheiro em projetos: as recomendações americanas PTI (2000), as francesas SETRA (2001) e as de um grupo internacional de pesquisadores FIB (2005).

Os critérios de fadiga são baseados essencialmente em análise experimental, em ensaios de cabos com comprimentos e áreas limitados e os resultados são extrapolados para o comportamento global do tirante.

O objetivo deste item é revisar os conceitos de fadiga relacionados ao aço de protensão, de forma a estabelecer um critério consistente para o projeto de pontes com protensão no extradorso.

\subsubsection{Ensaios de resistência à fadiga e curvas Wöhler.}

O ensaio clássico de barras ou cordoalhas de aço consiste em ancorar a amostra em uma extremidade e na outra instalar uma tensão inicial, fazendo-a variar de forma gradual e alternada ao longo do tempo entre dois pontos pré-estabelecidos (fig. 2.28). Sendo a resistência à fadiga caracterizada pelo número de ciclos em que a amostra rompe para determinada flutuação de tensão.

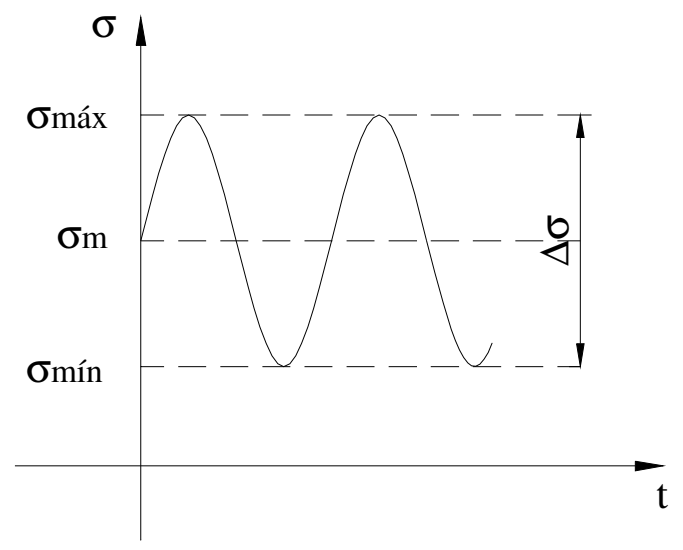

Figura 2.28 - Variação de tensão axial durante ensaio de fadiga.

As tensões máximas e mínimas são dadas por: 


$$
\begin{aligned}
& \sigma_{\text {max }}=\sigma_{m}+\frac{\Delta \sigma}{2} \\
& \sigma_{\text {min }}=\sigma_{m}-\frac{\Delta \sigma}{2}
\end{aligned}
$$

Logo,

$$
\Delta \sigma=\sigma_{\text {máx }}-\sigma_{\text {min }}
$$

Os resultados de diversas amostras submetidas a flutuações de tensão diferentes são, normalmente, apresentados graficamente e são conhecidos como curvas de Wöhler (fig. 2.29). Estas curvas são dadas para uma determinada tensão máxima (média ou mínima) e relaciona a flutuação de tensão com o numero de ciclos ao qual o material resiste.

Freqüentemente, a curva Wöhler é representada por duas linhas retas, sendo que a partir de um determinado número de ciclos a oscilação da tensão tem pequena variação e a reta é quase horizontal.

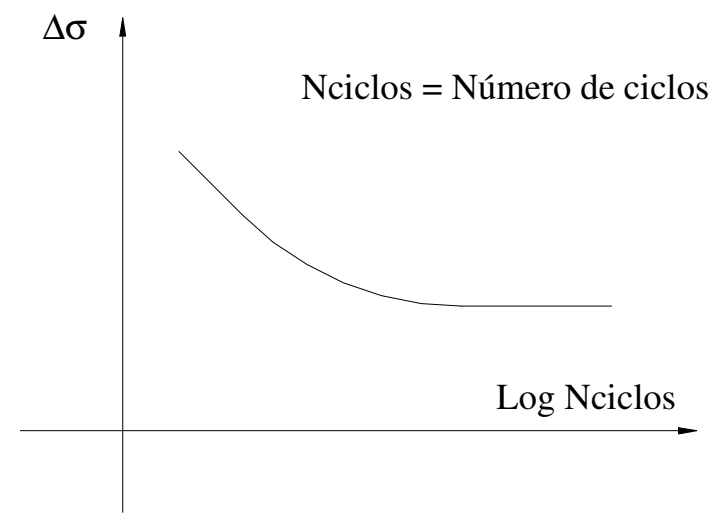

Figura 2.29 - Exemplo de curva Wöhler para cordoalhas de aço protendido.

Denomina-se resistência limite à fadiga, para a tensão máxima de referência de ensaio, a máxima flutuação de tensão que a peça suporta independente do número de ciclos, o que corresponde a considerar uma reta horizontal na curva Wöhler. Em casos práticos, a determinação deste limite é impraticável, devido à duração dos 
ensaios e com isso, convenciona-se que o número de ciclos representativo do comportamento a longo prazo do aço protendido é de 2 milhões.

Finalmente, é preciso estabelecer um critério para determinar o valor limite da resistência à fadiga a ser aplicada em projeto. Em regra geral, recomenda-se que após o ensaio de fadiga, a amostra, que não deve ter sofrido ruptura, seja submetida a um ensaio de ruptura por tração, sendo que a resistência residual deve ser maior que $95 \%$ de $f_{\text {ptk }}$ (da amostra intacta).

Percebe-se que as curvas Wöhler dependem de um valor fixo de tensão que, normalmente, é tomado o valor máximo. Portanto, a determinação da resistência limite para diversos valores de tensão adotada é demorada e dispendiosa. No entanto, é possível representar a flutuação limite de fadiga $\left(\Delta \sigma_{\text {fad }}\right)$ como função de $\sigma_{\text {máx }}$ que pode ser linearizada como mostra o diagrama de Goodman (figura 2.30).

No caso do aço protendido, existem algumas particularidades que serão estudadas a seguir, como a fadiga na região das ancoragens e a por fricção, que podem gerar discrepâncias no diagrama proposto por Goodman, para aço passivo.

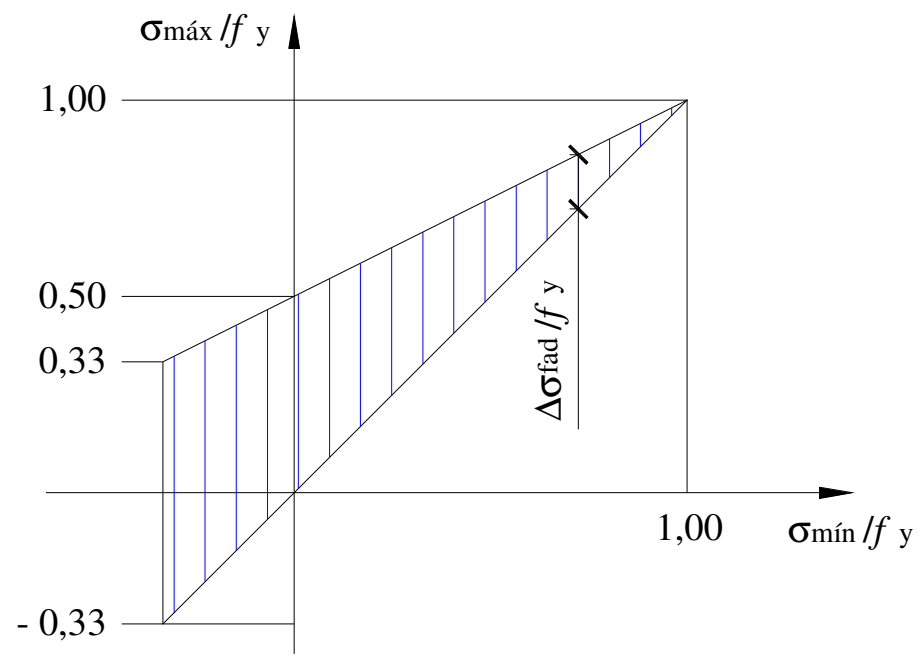

Figura 2.30 - Diagrama de Goodman para armaduras passivas.

O ensaio descrito é conhecido, habitualmente, como de variação pura de tração com amostras ao ar, e em muitos casos não representa a realidade. Isto ocorre por que não são considerados outros efeitos que podem ser determinantes para os danos de fadiga como: tensões de flexão nos cabos, agressividade do meio ambiente, fricção entre superfícies, etc. 


\subsubsection{Fadiga por fricção ("fretting fatigue")}

A combinação da ação de fricção entre metais e altas pressões locais de contato em cordoalhas sujeitas a fadiga pode levar a abrasões no contato dos elementos e acelerar a formação e propagação de fissuras de fadiga nos fios (RYALS et al., 1993). Este fenômeno é comumente conhecido como fadiga por fricção ("fretting fatigue") e pode causar uma ruptura prematura da cordoalha, pois diminui apreciavelmente a resistência a fadiga das cordoalhas quando comparada aos testes realizados ao ar.

É importante o conhecimento do fenômeno de fadiga por fricção, mesmo em estruturas de concreto com protensão aderente, pois pesquisas mostram que ocorre a perda da aderência entre o aço e o concreto adjacente às fissuras de flexão durante carregamento cíclico, o que leva a deslizamentos da armadura. Obviamente, esta preocupação também é pertinente no caso de protensão não aderente e, principalmente, de protensão externa, já que devido aos pequenos raios dos desviadores as pressões de contato são bastante elevadas.

a)

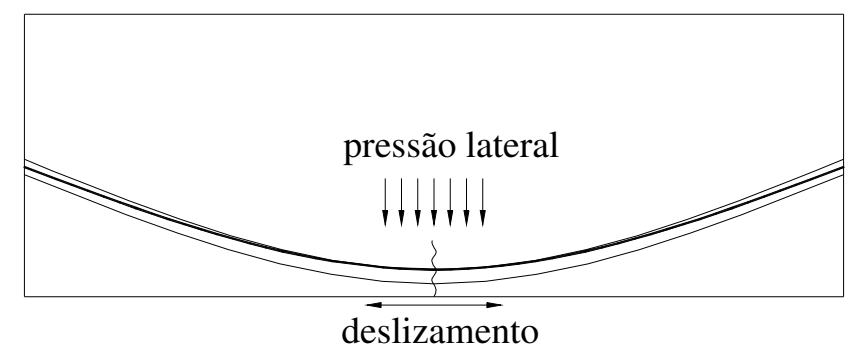

b)

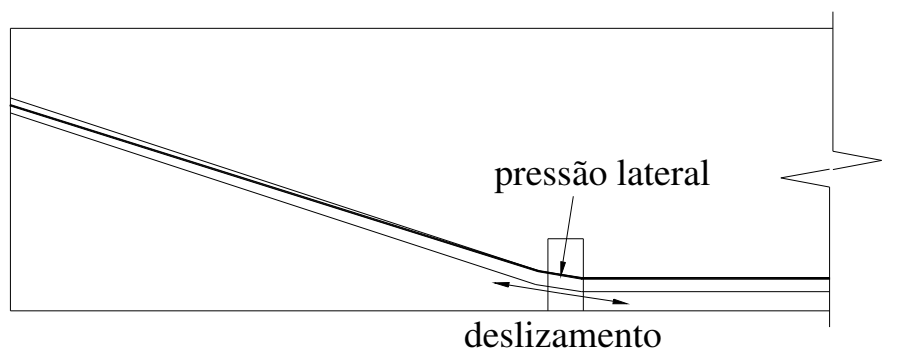

Figura 2.31 - Condições favoráveis aos danos de fadiga por fricção, (a) protensão aderente e (b) protensão externa.

WOLLMANN et al. (1996) realizaram vários ensaios em vigas de concreto (em escala real e reduzida) com protensão aderente com bainhas metálicas e de 
polietileno. Assegurou-se que houvesse fissuras no concreto para permitir o deslizamento do aço sob carregamento cíclico. A partir dos resultados foram elaboradas as seguintes conclusões:

A fricção entre cordoalhas e entre a bainha e cordoalha reduz a expectativa de vida à fadiga das vigas com cabos curvos e aderentes. Por essa razão, os resultados de ensaios de amostras ao ar não são adequados para representar tal situação;

$>$ A utilização de bainhas plásticas melhora o desempenho de apenas uma cordoalha, pois elimina a fricção entre cordoalha e bainha. No entanto, em cabos com múltiplas cordoalhas, a fricção entre elas torna o uso de bainha plástica menos efetiva;

> Um único ensaio, com emprego de recobrimento de epóxi, mostrou que a fricção entre cordoalhas e entre bainha e cordoalha foi eliminada, melhorando o comportamento à fadiga.

RYALS et al. (1993) apresentam resultados de estudos experimentais sobre a fadiga por fricção em vigas externamente protendidas. Foram montados três tipos de selas, onde o angulo de desvio do cabo foi pré-fixado $\left(10^{\circ}\right)$ e a da bainha foi selecionada para reproduzir três situações de instalação: ideal $\left(13^{\circ}\right)$, ruim $\left(7,5^{\circ}\right)$ e péssima $\left(2^{\circ}\right)$. As conclusões foram seguintes:

A fricção foi muito mais danosa nos desviadores desalinhados com o cabo, provavelmente devido a maiores pressões de contato. O número de ciclos determinados na situação ideal foi o dobro daquele onde o cabo e a bainha não estavam alinhados;

$>$ A maioria das fissuras de fadiga dos fios foi causada por fricção entre cordoalhas e entre os fios da mesma.

Existem algumas possibilidades para redução dos impactos da deterioração por fricção, como: redução da oscilação da tensão, redução das pressões de contato e do coeficiente de atrito. O método mais simples seria aplicar uma lubrificação duradoura entre as superfícies em contato. O recobrimento com metais suaves como 
o zinco ou o alumínio, tem efeitos favoráveis, ao contrário da galvanização a quente, devido à ligação quebradiça ferro-zinco (CHO, 2000). Além disso, o recobrimento de epóxi, que vem sendo utilizada em pontes com protensão no extradorso, também tem efeitos bastante favoráveis.

\subsubsection{Resistência à fadiga condicionada pelas ancoragens}

A resistência à fadiga dos estais é governada pelas ancoragens e não pela seção típica do cabo. Isso acontece por duas razões: devido às tensões locais, que enfraquecem os cabos e às deformações da ponte estaiada, que além de produzir variação de tensão axial, também desenvolve rotações nas ancoragens.

Tais rotações, que também são geradas por carregamentos aplicados ao longo do comprimento do cabo (como vento e peso próprio), desenvolvem tensões de flexão nos cabos que devem ser adicionadas aos efeitos dos esforços axiais.

\subsubsection{Tensões locais}

A transferência do esforço no cabo para a ancoragem é realizada por cisalhamento entre as superfícies dos fios e a superfície da cunha, o que gera concentração de tensões no contato, além da possibilidade de dano pelo aperto dos dentes da cunha. Ao submeter à ancoragem um carregamento cíclico, o nível de tensão nas mesmas reduz a expectativa de vida à fadiga em relação a uma seção típica do cabo de aço.

Existem algumas soluções para aumentar a resistência à fadiga condicionada às tensões locais. Para alguns sistemas de protensão, cunhas especiais foram projetadas para limitar a penetração na cordoalha, reduzindo assim, tais tensões. Porém, isso permite deslizamentos, e o problema da fadiga por fricção passa a ser uma preocupação (fig.2.32).

Outra solução pode ser o balanceamento da variação de tensão antes de atingir à ancoragem. Isto pode ser feito com o emprego de uma resina de epóxi flexível que, através de tensões de cisalhamento, reduz as tensões no nível da cunha. 


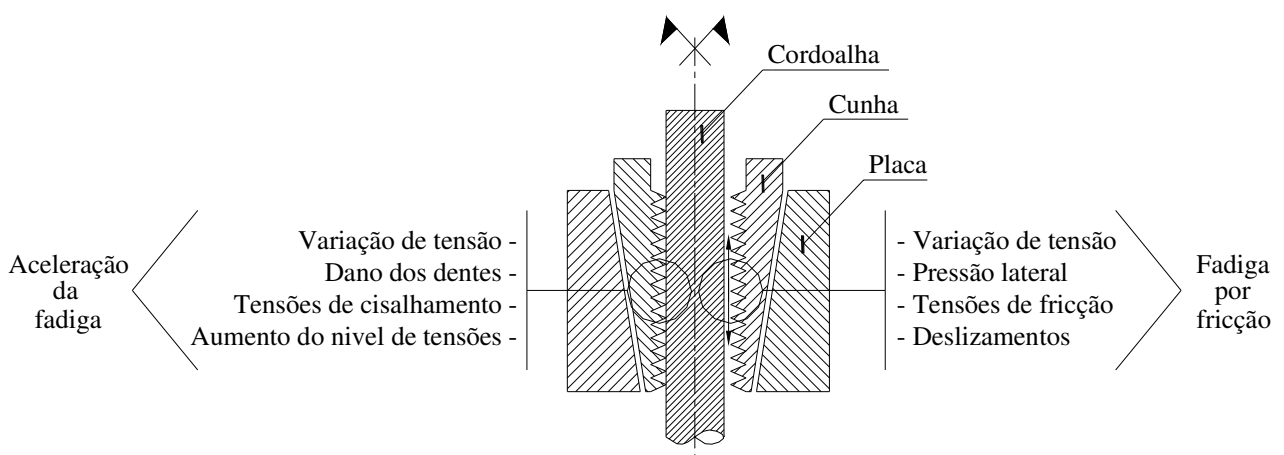

Figura 2.32 - Aceleração do processo da fadiga e fadiga por fricção nas ancoragens.

\subsubsection{Tensões de flexão}

As deformações da ponte sob efeito de diversas ações produzem rotações relativas entre o tabuleiro (ou a torre) e a ancoragem (figura 2.33). Essas rotações são difíceis de serem analisadas, uma vez que elas são também geradas por ações que não são claramente determinadas, tais como: variação de temperatura, ação do vento, tolerâncias de instalação das ancoragens e vibrações do cabo. Além disso, se considerarmos o efeito da curvatura do cabo ("sag effect") o problema se torna ainda mais complicado.

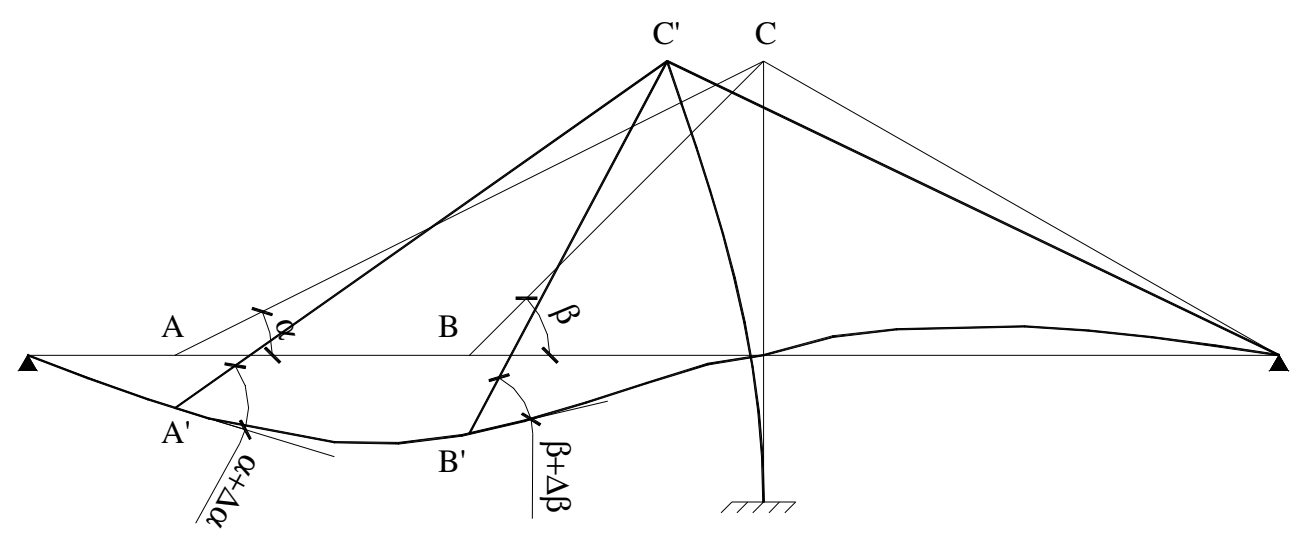

Figura 2.33 - Variação da rotação entre o cabo e o tabuleiro produzida por carregamento variável (adaptado de VIRLOGEUX, 1994).

Se a ancoragem for conectada a estrutura através de rótulas, de tal forma que possa girar livremente em relação ao tabuleiro (ou torre), as rotações relativas não 
serão produzidas e, conseqüentemente, não ocorrerão tensões de flexão. No entanto, o atrito mobilizado neste tipo de articulação pode produzir tensões não desprezíveis.

Uma solução bastante utilizada em pontes estaiadas para a redução ou eliminação de tensões de flexão nas ancoragens é o emprego de tubos de transição com guia desviador (fig. 2.34). Este guia desviador é instalado próximo à ancoragem, suportando lateralmente o cabo e limitando os deslocamentos transversais no ponto onde se encontra e, também, reduz as rotações relativas nas ancoragens. Embora essa solução permita amortecer parcialmente as vibrações dos cabos, é possível que sejam necessários utilizar amortecedores de fato.

Todas as soluções discutidas anteriormente para melhorar o desempenho da região das ancoragens tornam o custo dos sistemas estaiados muito elevado. Em virtude desse fato, VIRLOGEUX (1994) relata a tentativa, com pouco sucesso, de construir pontes estaiadas de médios vãos em competição com soluções clássicas.

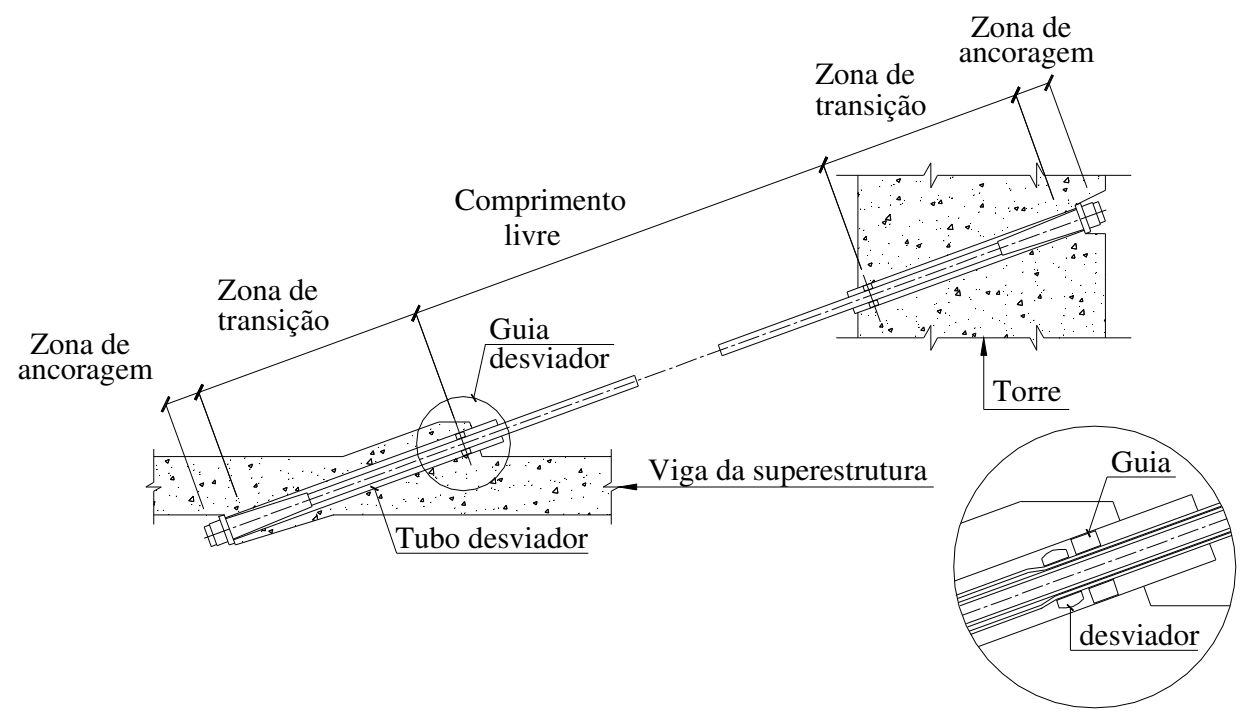

Figura 2.34 - Exemplo de sistema de ancoragem em estais (adaptado de FIB, 2005).

\subsubsection{Resistência à fadiga de sistemas de protensão com pós - tração}

Nos itens anteriores foi realizada uma pequena revisão qualitativa dos efeitos da fadiga em cabos pós-tracionados. Neste item será realizada uma revisão quantitativa, com as recomendações de alguns comitês internacionais e de 
pesquisadores, com o intuito de auxiliar a adoção de parâmetros para a análise paramétrica que se realizará mais adiante.

Diversos ensaios de fadiga de cordoalhas ao ar mostram que quanto maior for a tensão máxima, menor é a sua resistência. Esta é uma razão para que em pontes estaiadas a tensão máxima permitida em serviço seja entre $40 \%$ e $45 \%$ de $f_{\text {ptk. }}$.

Pesquisadores da Universidade do Texas fizeram diversos ensaios de fadiga com cordoalhas ao ar para utilização em estruturas de concreto protendido. Através dos resultados obtidos, foi sugerida uma curva Wöhler, onde o valor da resistência limite a fadiga é de 140 MPa (RYALS et al., 1993) \& (WOLLMANN et al., 1996).

RYALS et al. (1993) sugerem que a resistência à fadiga de vigas de concreto com protensão externa deve estar de acordo com as recomendações da AASHTO de 1989 para a curva de variação de tensão admissível da categoria C (estruturas de rota de carga excessiva). O limite de resistência à fadiga é de $70 \mathrm{MPa}$, no entanto, essa recomendação foi realizada considerando condições ruins de instalação dos desviadores.

As recomendações para os estais são bastante diferentes e, conforme discutido no item 2.6.4, depende das ancoragens. PTI (2000) especifica as flutuações de tensão máximas para fios, cordoalhas e barras (com 2 milhões de ciclos) iguais a 194, 159 e $105 \mathrm{MPa}$, respectivamente. Segundo FIB (2005) estes valores mostraram bons resultados no passado. Contudo, materiais melhores se tornaram disponíveis e recomendações mais recentes como SETRA (2001) e muitas outras têm especificado o valor de $200 \mathrm{MPa}$ para cordoalhas.

As especificações para aceitação do sistema de cabo do SETRA (2001) para cordoalhas e barras são respectivamente 200 e 110 MPa. Tanto PTI (2000) como SETRA (2001) limitam a tensão máxima em $45 \%$ da resistência característica à tração do aço, sendo que o último limita também a variação da rotação angular em $\pm 10 \mathrm{mrad}\left( \pm 0,6^{\circ}\right)$. Além disso, estes dados são especificações de ensaios e o uso em projeto tem que ser minorado por fatores de segurança.

FIP (1993) especifica que a resistência mínima a fadiga de sistemas póstracionados, para uma tensão máxima de $65 \% f_{\text {ptk }}$, deverá ser definida por uma oscilação de $80 \mathrm{MPa}$ para 2 milhões de ciclos, sem que apresente ruptura de mais de $5 \%$ da área inicial do cabo ensaiado. 
SETRA (2001) faz recomendações para resistência à fadiga de cordoalhas, considerando 2 milhões de ciclos para as três categorias de protensão (tabela 2.3).

Tabela 2.3 - Resistência à fadiga de cordoalhas a 2 milhões de ciclos (adaptado de SETRA, 2001).

\begin{tabular}{|c|c|c|c|}
\hline Categoria de utilização & Estais & Protensão extradorsal & Protensão externa \\
\hline$\Delta \sigma_{\text {fad }}$ & $200 \mathrm{MPa}$ & $140 \mathrm{MPa}$ & $80 \mathrm{MPa}$ \\
\hline Variação angular $(\Delta \alpha)$ & $10 \mathrm{mrad}$ & 0 & 0 \\
\hline$\sigma_{\text {máx }}$ & $0,45 f_{\text {ptk }}$ & $0,55 f_{\text {ptk }}$ & $0,65 f_{\text {ptk }}$ \\
\hline$\sigma_{\text {mín }}$ & $0,45 f_{\text {ptk }}-200 \mathrm{MPa}$ & $0,55 f_{\text {ptk }}-140 \mathrm{MPa}$ & $0,65 f_{\text {ptk }}-80 \mathrm{MPa}$ \\
\hline$\alpha_{\text {máx }}$ & $10 \mathrm{mrad}$ & 0 & 0 \\
\hline$\alpha_{\text {mín }}$ & $0 \mathrm{mrad}$ & 0 & 0 \\
\hline
\end{tabular}

Para a construção da primeira ponte com protensão no extradorso (Odawara Blueway), foi realizada uma série de ensaios para estudar o método de instalação e tensionamento dos cabos externos Dywidag. O ensaio consistiu na protensão de 19 cordoalhas de 15,2 mm com recobrimento de epóxi e bainhas de polietileno com tensionamento por ambos extremos do cabo. No centro, os cabos estavam desviados por uma sela que simulava o comportamento no topo da torre. Os resultados estão apresentados na tabela 2.4 (CHO, 2000).

Tabela 2.4 - Resultados em escala real do comportamento do sistema de ancoragem da ponte Odawara Blueway, no Japão (CHO, 2000).

\begin{tabular}{|c|l|r|r|}
\hline \multirow{2}{*}{ Ensaio } & \multicolumn{2}{|c|}{ Condições do ensaio } & Resultados do ensaio \\
\hline \multirow{2}{*}{1} & Tensão mínima & $0,6^{*} f_{\mathrm{pu}}$ & \multirow{2}{*}{ Sem ruptura } \\
\cline { 2 - 3 } & Oscilação de tensão & $100 \mathrm{MPa}$ & \\
\cline { 2 - 3 } & Número de ciclos & $2 \times 10^{6}$ & \\
\hline \multirow{2}{*}{2} & Tensão mínima & $0,45^{*} f_{\mathrm{pu}}$ & \multirow{2}{*}{ Sem ruptura } \\
\cline { 2 - 3 } & Oscilação de tensão & $200 \mathrm{MPa}$ & \multirow{2}{*}{ Sem ruptura } \\
\cline { 2 - 3 } & Número de ciclos & $2 \times 10^{6}$ & \\
\hline \multirow{3}{*}{3} & Tensão mínima & $0,45^{*} f_{\mathrm{pu}}$ & \multirow{2}{*}{$2 \times 10^{6}$} \\
\cline { 2 - 3 } & Oscilação de tensão & $250 \mathrm{MPa}$ & \\
\cline { 2 - 3 } & Número de ciclos & $2 \times 1$ & \\
\end{tabular}


Os resultados dos ensaios da tabela 2.4 não apresentaram nem ruptura, nem deslizamentos nas cunhas, além do ensaio estático respeitar o critério de resistência residual superior a 95\% da resistência inicial.

A ponte estaiada do Brotonne foi a primeira a utilizar selas no topo da torre, no entanto, alguns engenheiros consideravam que o uso de selas reduzia a capacidade resistente à fadiga dos cabos. Devido às críticas, para a construção da ponte Coatzacoalcos, foram realizados testes de fadiga no EMPA (suíça), sendo os mesmos reproduzidos dois anos depois para a construção da ponte Sunshine Skyway. Ambos evidenciaram que a fadiga era governada pelas ancoragens e não pela região da sela (VIRLOGEUX, 1994). É válido ressaltar que todos estes testes não permitiram deslizamentos no topo da sela, pois poderia ocorrer fadiga por fricção.

No caso especifico das pontes com protensão no extradorso, as recomendações do SETRA (2001) são: para o estado limite de serviço, combinação rara, a força atuante no cabo tem que ser menor ou igual a $60 \%$ da capacidade resistente característica do cabo e a flutuação de tensão máxima dos tirantes para a combinação freqüente das cargas tem que ser menor ou igual a $50 \mathrm{MPa}$.

A adoção da flutuação de tensão máxima igual a $50 \mathrm{MPa}$ parece bem razoável, pois embora existam recomendações para a protensão externa de tal flutuação ser igual a $80 \mathrm{MPa}$, os efeitos de vibração e as tensões de flexão na região das ancoragens dos cabos no extradorso podem ser negligenciados, devido a um fator de segurança de 1,6 .

A partir da revisão bibliográfica realizada neste item, podemos definir alguns critérios que serão utilizados no estudo paramétrico, bem como sugestões para projetos de pontes com protensão no extradorso:

$>$ Com o intuito de empregar uma tecnologia similar à utilizada em estruturas com protensão externa, é preciso tomar alguns cuidados como: não permitir deslizamentos em selas e utilizar tubo de transição com guias e desviadores na região da ancoragem, de forma a eliminar ou poder negligenciar as tensões de flexão no cabo;

> Recomenda-se aplicar proteções contra corrosão do cabo, como por exemplo, recobrimento de epóxi e bainhas de polietileno que também permite melhorar a resistência à fadiga por corrosão e/ou fricção; 
$>$ A integridade estrutural dos cabos devido à fadiga é considerada satisfatória, se a máxima flutuação de tensão em serviço (combinação freqüente) não superar $50 \mathrm{MPa}$ e a tensão máxima para a combinação rara não ultrapasse $60 \%$ da resistência característica de ruptura do aço de protensão. 


\section{ESTUdO PARAMÉTRICO}

\subsection{INTRODUÇÃO}

O comportamento estrutural de uma ponte com protensão no extradorso, assim como ocorre nas pontes estaiadas, é o resultado da interação de diversos parâmetros. Por se tratar de uma estrutura com alto grau de hiperestaticidade, a alteração de uma ou mais características pode modificar substancialmente o funcionamento da ponte.

Os parâmetros considerados mais importantes são: altura da torre e do tabuleiro, nível de tensão nos tirantes, grau de compensação das cargas permanentes, relação entre os vãos lateral e central, o emprego de protensão interna e externa de pequena excentricidade, altura variável do tabuleiro, tipo de ligação entre a superestrutura e o pilar e a distância do primeiro cabo em relação à torre.

Uma forma de tentar entender o comportamento estático desse tipo de ponte é fazer variar, um a um, esses parâmetros, de forma a determinar a influência que os mesmos têm sobre o desempenho do conjunto.

Essa análise será realizada tendo em vista a investigação dos parâmetros mais significativos, focando o estudo na determinação de dimensões prévias, de tal forma que o comportamento da estrutura não seja governado por danos de fadiga, ou seja, que as flutuações de tensão nos cabos estejam dentro do limite estabelecido no capítulo 2 .

A premissa básica adotada foi a transposição de um vão de $150 \mathrm{~m}$ que acreditamos ser um valor intermediário do campo de aplicação das pontes com tabuleiros de concreto. Os diversos modelos, definidos adiante, foram elaborados no 
programa de análise estrutural ADINA (Automatic Dinamic Incremental NonLinear Analysis).

\subsection{MÉTODO DE ANÁLISE}

Por se tratar de um estudo comparativo e não do dimensionamento de uma solução específica, foram utilizados modelos de barras considerando que a estrutura tem comportamento linear.

Os tirantes foram representados por elementos de treliça e a perda de rigidez devido ao efeito da curvatura dos cabos foi desprezada, sendo que mais adiante será mostrado que essa análise é desnecessária. Entretanto, poderíamos levar em consideração essa redução através de uma correção no módulo de elasticidade do aço formulada por Dischinger e mostrada a seguir:

$$
E^{*}=\frac{E_{p}}{1+\frac{\gamma_{p} \cdot L_{H}{ }^{2} \cdot E_{p}}{12 \cdot \sigma_{m}{ }^{3}}}
$$

onde $E^{*}$ é o módulo de elasticidade de Dischinger, $E_{p}$ e $\gamma_{p}$ são o módulo de elasticidade e o peso específico do aço protendido no extradorso, respectivamente, $L_{H}$ é a projeção horizontal do comprimento do cabo no extradorso e $\sigma_{m}$ é a tensão média no cabo.

Na análise é assumido que os cabos protendidos são capazes de suportar tensões de compressão, embora estas não devam ocorrer. Se, por ventura, existir algum cabo submetido à compressão ou à tração relativamente pequena (menor que $\left.0,15 f_{p t k}\right)$, a geometria será reavaliada.

Os efeitos de retração e fluência do concreto foram negligenciados, assim como a relaxação do aço. No entanto, em projeto de tal tipo de estruturas esses efeitos devem ser avaliados.

É assumido que a estrutura se comporta elasticamente, cuja formulação é baseada na teoria de viga de Bernoulli-Euler. 


\subsection{PARÂMETROS ADOTADOS}

\subsubsection{Propriedades físicas dos materiais}

As propriedades físicas do concreto utilizado no tabuleiro e na torre são:

> Resistência característica à compressão: $f_{c k}=40 \mathrm{MPa}$;

Módulo de elasticidade: $E_{c}=30000 \mathrm{MPa}$;

$>$ Peso específico: $\gamma_{c}=25 \mathrm{kN} / \mathrm{m}^{3}$.

$\mathrm{O}$ aço de protensão utilizado tanto para a protensão extradorsal, como para a interna foi o CP190RB que possui as seguintes propriedades físicas:

$>$ Resistência característica à tração: $f_{p t k}=1900 \mathrm{MPa}$;

Módulo de elasticidade: $E_{p}=195000 \mathrm{MPa}$;

Peso específico: $\gamma_{p}=78,5 \mathrm{kN} / \mathrm{m}^{3}$.

\subsubsection{Modelo básico}

$\mathrm{Na}$ análise paramétrica, foi adotado um modelo básico que possui dimensões típicas de uma ponte com protensão no extradorso com altura de tabuleiro constante. Nesse modelo foram adotados também alguns parâmetros que, conforme já descrito, serão alterados, individualmente, sendo mantidos constantes os restantes. Esse procedimento visa identificar a influência de cada um no comportamento estrutural da ponte.

Foi adotada uma ponte com três vãos de comprimento 90 m, 150 m e 90 m, sendo a relação entre o vão lateral e o central igual a 0,6. A altura da torre é $15 \mathrm{~m}$ (L/10) e a altura do tabuleiro 4,5 m ( L/33). As seções transversais da torre e do tabuleiro estão indicadas na figura 3.1. 


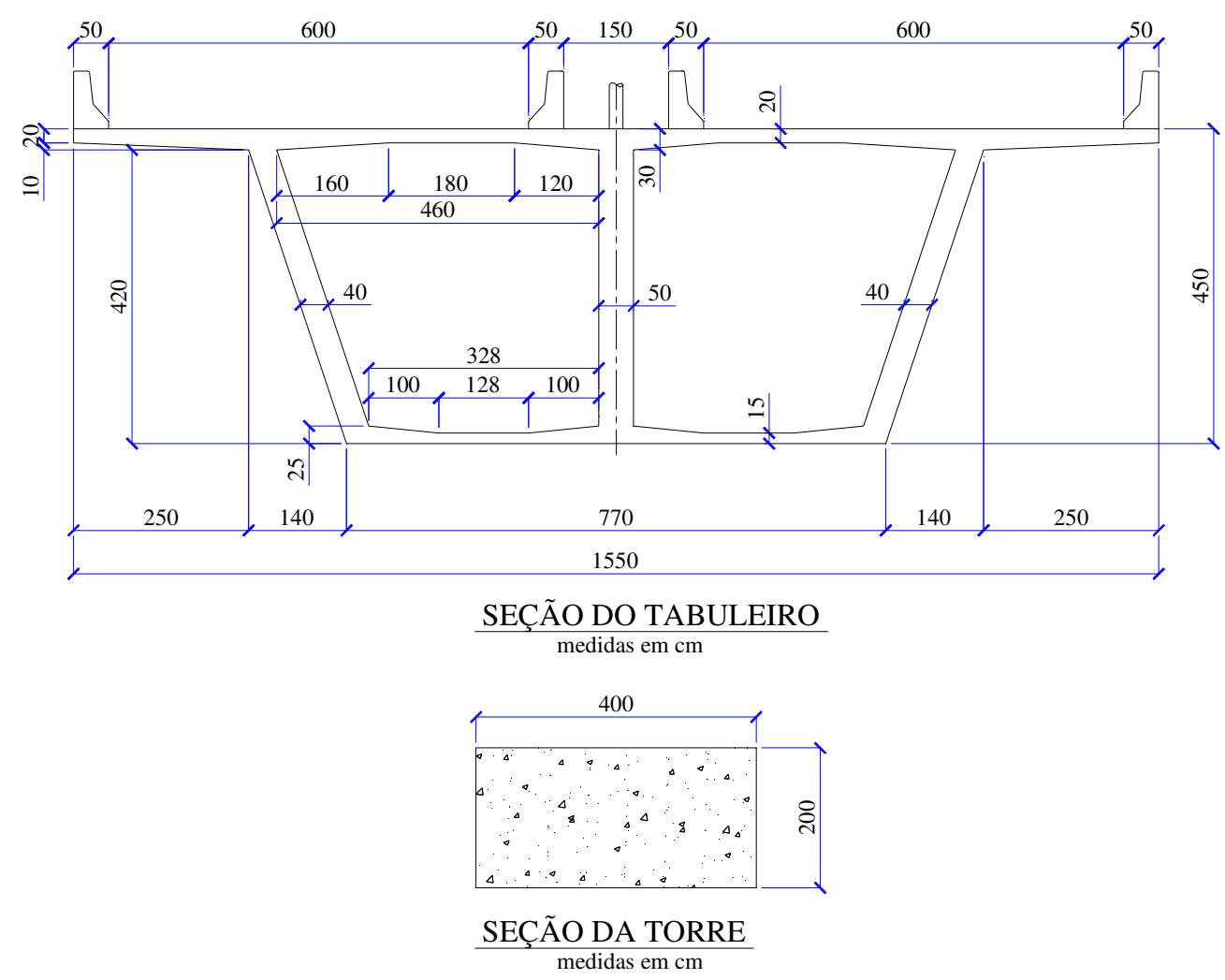

Figura 3.1 - Seções transversais do tabuleiro e da torre do modelo básico.

Embora se admita que a ponte seja construída em uma só fase, para o cálculo da protensão necessária em cada cabo, foi assumido que a construção se deu pelo método dos balanços sucessivos. A hipótese básica é que à medida que um par de cabos (simétricos em relação à torre) é instalado, o deslocamento vertical do tabuleiro nos pontos de inserção de tais cabos é nulo.

A tensão máxima permitida nos tirantes para a combinação rara das cargas é de $60 \%$ de $f_{p t k}$, ou seja, $\sigma_{a d m}=0,6 f_{p t k}=0,6 \cdot 1900=1140 \mathrm{MPa}$. A máxima flutuação de tensão no sistema de cabos no extradorso para a combinação freqüente das cargas, conforme visto no capítulo 2, é igual a $50 \mathrm{MPa}$.

O sistema longitudinal dos cabos adotado em todos os modelos possui disposição em semi-harpa. Em razão do uso de selas no topo da torre, o espaçamento adotado entre os cabos nessa região foi de $40 \mathrm{~cm}$.

Por razões estéticas e simplicidade dos detalhes de ancoragem, foram empregadas disposições simétricas dos cabos em relação aos apoios intermediários (eixo da torre). 
O sistema transversal dos cabos foi escolhido em função da adoção de seção transversal celular no tabuleiro, que possui elevada rigidez à flexão e à torção. Em razão disso, optou-se por uma suspensão central por ter melhores características estéticas, funcionais e estáticas para a viga celular adotada.

O espaçamento dos cabos no extradorso foi adotado considerando o tabuleiro construído pelo método dos balanços sucessivos. Segundo MENN (1990), em tabuleiros esbeltos e flexíveis (ponte estaiada), esse espaçamento deve ser de tal forma que permita a montagem da aduela sem a necessidade de tirantes provisórios. Com isso, esse valor corresponde, normalmente, ao comprimento da aduela que varia tipicamente entre 6 e $8 \mathrm{~m}$.

Por outro lado, nas pontes em viga reta as seções são maiores, o que eleva o peso por unidade de comprimento e reduz a dimensão de uma aduela que varia, usualmente, entre 3 e $5 \mathrm{~m}$. Em virtude disso, e levando em consideração que os tabuleiros das pontes com protensão no extradorso têm dimensões intermediárias, o espaçamento considerado em todos os casos analisados foi $5 \mathrm{~m}$.

A distância do primeiro cabo em relação à torre, geralmente, se encontra entre $18 \%$ a $20 \%$ do vão principal, sendo tomado o valor de $28 \mathrm{~m}$.

Finalmente, foram dispostas transversinas em todos os pontos de inserção dos cabos no tabuleiro para auxiliar no equilíbrio das forças introduzidas pelos tirantes e, também, para evitar o surgimento de distorções indesejadas nas seções de ancoragem dos cabos.

A figura 3.2 mostra as características geométricas adotadas no modelo básico.

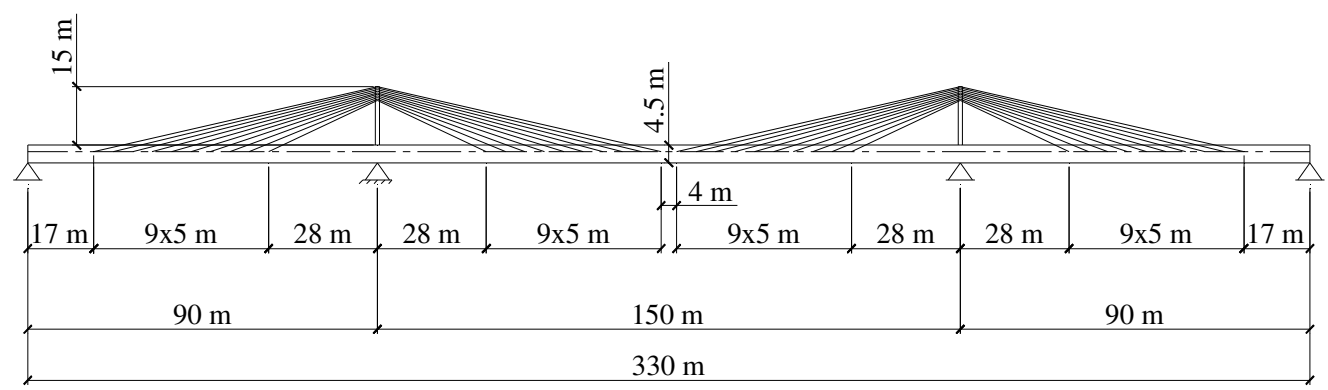

Figura 3.2 - Modelo básico. 


\subsection{PARÂMETROS ANALISADOS}

\subsubsection{Altura da torre e do tabuleiro}

Além da altura da torre adotada no modelo básico, foram considerados mais dois valores baseados na recomendação de MATHIVAT (1988) e na relação entre a altura da torre e o vão principal usualmente empregada nas pontes estaiadas, que têm dimensões iguais a $10 \mathrm{~m}(\mathrm{~L} / 15)$ e $30 \mathrm{~m}(\mathrm{~L} / 5)$, respectivamente. As propriedades geométricas estão resumidas na tabela 3.1.

Tabela 3.1 - Propriedades geométricas das seções transversais adotadas nas torres.

\begin{tabular}{|c|c|c|c|c|c|}
\hline $\mathrm{H}(\mathrm{m})$ & Dimensões $(\mathrm{m})$ & $\mathrm{y}_{\mathrm{i}}(\mathrm{m})$ & $\mathrm{y}_{\mathrm{s}}(\mathrm{m})$ & $\mathrm{A}\left(\mathrm{m}^{2}\right)$ & $\mathrm{I}\left(\mathrm{m}^{4}\right)$ \\
\hline $10(\mathrm{~L} / 15)$ & $2 \times 3,5$ & 1,75 & 1,75 & 7,00 & 7,146 \\
\hline $15(\mathrm{~L} / 10)$ & $2 \times 4,0$ & 2,00 & 2,00 & 8,00 & 10,667 \\
\hline $30(\mathrm{~L} / 5)$ & $2 \times 5,0$ & 2,50 & 2,50 & 10,00 & 20,833 \\
\hline
\end{tabular}

Para a definição de mais duas alturas de tabuleiro, procurou-se utilizar alturas intermediárias entre aquelas correspondentes às pontes de concreto protendido em viga reta (mais robustas) e às estaiadas (muito esbeltas). Com isso, os valores adotados foram: $3 \mathrm{~m}(\mathrm{~h}=\mathrm{L} / 50)$ e $6 \mathrm{~m}(\mathrm{~h}=\mathrm{L} / 25)$. As propriedades geométricas estão resumidas na figura 3.2 .

Tabela 3.2 - Propriedades geométricas das seções transversais adotadas em todos os tabuleiros de seção constante considerados.

\begin{tabular}{|c|c|c|c|c|}
\hline $\mathrm{h}(\mathrm{m})$ & $\mathrm{y}_{\mathrm{i}}(\mathrm{m})$ & $\mathrm{y}_{\mathrm{s}}(\mathrm{m})$ & $\mathrm{A}\left(\mathrm{m}^{2}\right)$ & $\mathrm{I}\left(\mathrm{m}^{4}\right)$ \\
\hline $3,0(\mathrm{~L} / 50)$ & 1,82 & 1,18 & 8,614 & 11,143 \\
\hline $4,5(\mathrm{~L} / 33)$ & 2,67 & 1,83 & 10,384 & 28,488 \\
\hline $6,0(\mathrm{~L} / 25)$ & 3,55 & 2,45 & 12,184 & 56,158 \\
\hline
\end{tabular}

Combinando as alturas de torre com as alturas de tabuleiro, temos nove modelos, incluindo o básico. Ressalta-se que todos os parâmetros restantes são os mesmos descritos no item 3.3. A numeração de cada um deles está indicada na tabela 3.3 e são: 1, 2, 3, 4a, 5a (básico), 6a, 7a, 8a e 9a. 


\subsubsection{Nível de tensão dos cabos no extradorso}

Conforme já discutido, a tensão máxima admissível dos cabos no extradorso é, usualmente, igual a sessenta por cento da tensão de ruptura do aço $\left(0,6 \cdot f_{p t k}\right)$, enquanto nas pontes estaiadas a tensão admissível, normalmente, é de quarenta e cinco por cento do mesmo valor $\left(0,45 \cdot f_{p t k}\right)$. De maneira a investigar a influência desse parâmetro, foram elaborados mais seis modelos similares aos 4a, 5a, 6a, 7a, 8a, 9a, porém com tensão admissível igual a: $0,45 \cdot 1900=855 \mathrm{MPa}$.

Esses modelos adicionais estão indicados na tabela 3.3 com a numeração: 4b, $5 b, 6 b, 7 b, 8 b$ e $9 b$.

\subsubsection{Grau de compensação das cargas permanentes}

A hipótese de deslocamento vertical nulo, sob a ação da totalidade das cargas permanentes e da protensão nos tirantes, conforme será detalhado no item 3.6, considera que o tabuleiro tenha sido construído pelo método dos balanços sucessivos.

CHO (2000) faz um estudo paramétrico de uma ponte com características similares à da ponte Odawara Blueway durante a construção pelo método dos balanços sucessivos. O resultado da análise mostra que para a compensação total das cargas permanentes surgem tensões elevadas de tração nas fibras inferiores do tabuleiro, à medida que os tirantes são instalados, tornando inviável essa condição. Em uma segunda análise CHO (2000) estabelece que o valor ótimo de compensação de cargas permanentes para a ponte em estudo é de $80 \%$.

Diante do exposto e uma vez que não será realizado um estudo das pontes com protensão no extradorso construídas pelo método dos balanços sucessivos, foi realizado um modelo adicional (derivado do modelo básico) com compensação de

$80 \%$ das cargas permanentes para avaliar a sua influência no comportamento estrutural (tabela 3.3, modelo 5c). 


\subsubsection{Vão lateral}

O vão lateral é um parâmetro de extrema importância no projeto de uma ponte com protensão no extradorso. A relação entre os vãos lateral e central deve ser bem escolhida para que não seja necessário utilizar contrapesos, assim como na ponte Tsukuhara $\left(L_{l} / L \cong 0,36\right)$.

A priori, não parece ser recomendável a utilização de cabos de ancoragem, uma vez que estes são os cabos com maior flutuação de tensão numa ponte estaiada, contudo para a análise da proporção do vão lateral, será adotado um modelo no qual a relação entre os vãos é de 0,48 , o que significa que os cabos extremos estarão posicionados sobre o apoio extremo. Além desta proporção foram assumidos os seguintes valores de $\mathrm{L}_{l} / \mathrm{L}: 0,50 ; 0,55 ; 0,65$ (tabela 3.3 , modelos $5 \mathrm{~d}, 5 \mathrm{e}, 5 \mathrm{f} \mathrm{e} 5 \mathrm{~g}$ ).

Obviamente, este estudo só tem fundamento para dimensões típicas de uma ponte com protensão no extradorso (figura 3.3), ou seja, com as alturas de torre e de tabuleiro iguais às do modelo básico.

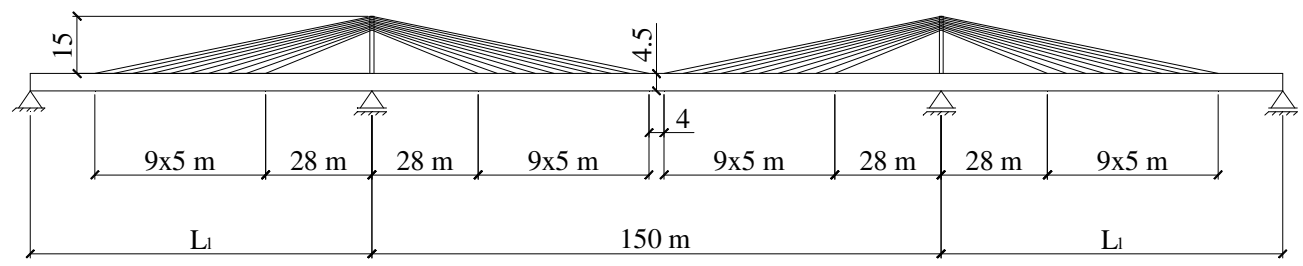

Figura 3.3 - Características geométricas adotadas para o estudo do vão lateral.

\subsubsection{Altura variável do tabuleiro}

De forma a determinar a influência do emprego de alturas variáveis no tabuleiro, foi realizado um modelo adicional com intuito de compará-lo ao básico.

Inicialmente, as características geométricas foram escolhidas através das recomendações de CHO (2000) e estão indicadas na figura 3.4. A altura do tabuleiro nos apoios intermediários é de $5 \mathrm{~m}\left(\mathrm{~h}_{\mathrm{c}}=\mathrm{L} / 30\right)$ e no trecho central é de 3,3 $\left(\mathrm{h}_{\mathrm{a}}\right.$ L/45), sendo a razão entre eles igual a 1,5. A distância entre o eixo da torre e o primeiro tirante é $38 \mathrm{~m}(\sim 0,25 \mathrm{~L})$ e entre a torre e o ponto onde a seção se torna constante é $27 \mathrm{~m}(0,18 \mathrm{~L})$. A altura da torre é igual a $15 \mathrm{~m}(\mathrm{~L} / 10)$ e apesar de a viga 
ter inércia variável, o que influencia na determinação da proporção entre os vãos, será adotado o mesmo valor considerado no modelo básico.

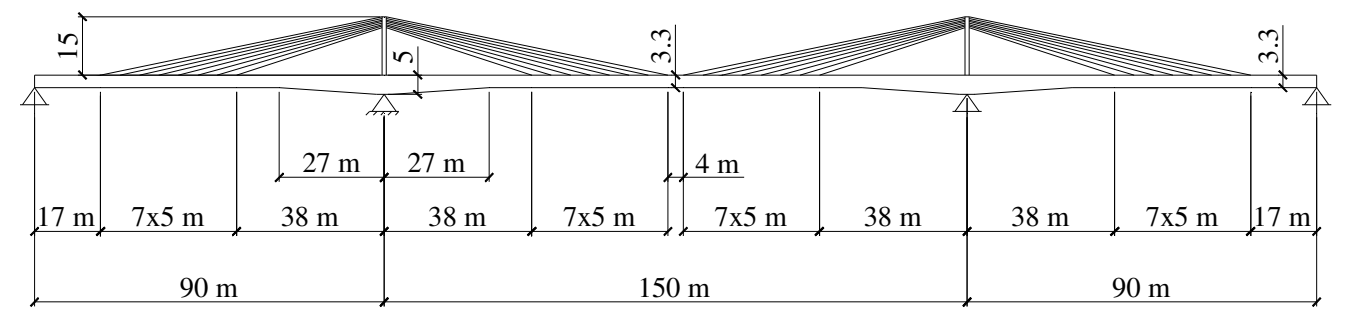

Figura 3.4 - Modelo com tabuleiro variável (modelo 10).

A variação da altura do tabuleiro foi considerada linear, embora seja mais comum a utilização de uma forma parabólica que acompanha o diagrama de momentos fletores permanentes.

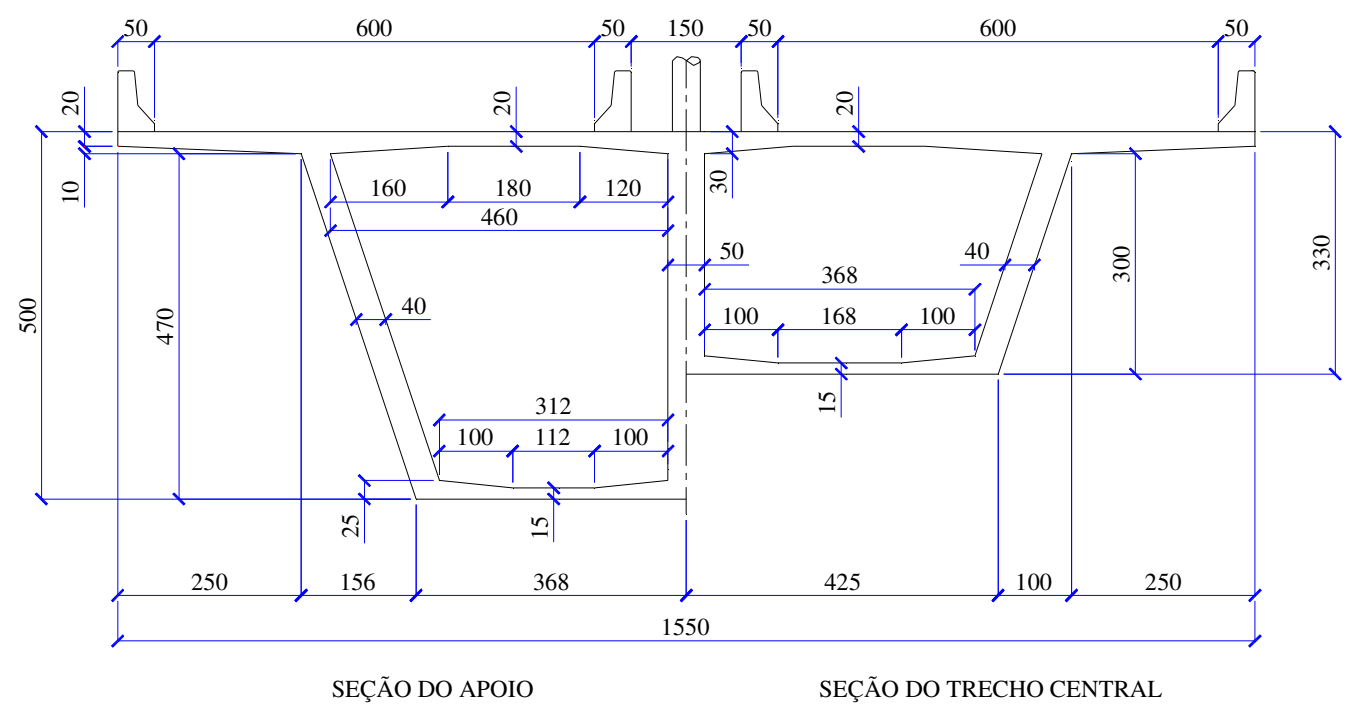

Figura 3.5 - Seções transversais adotadas no modelo que possui tabuleiro com seção variável. 


\subsubsection{Modelos considerados}

A tabela 3.3 exibe todos os modelos realizados no estudo paramétrico.

Tabela 3.3 - Modelos analisados.

\begin{tabular}{|c|c|c|c|c|c|}
\hline Modelo & $\mathrm{H}(\mathrm{m})$ & $\mathrm{h}(\mathrm{m})$ & $\sigma_{\text {adm }} / f_{\text {ptk }}$ & $\begin{array}{c}\text { Compensação } \\
\text { de carga } \\
\text { permanente }\end{array}$ & $\begin{array}{c}\text { Vão } \\
\text { lateral }\end{array}$ \\
\hline 1 & 10 & 3,0 & $60 \%$ & $100 \%$ & $90 \mathrm{~m}$ \\
\hline 2 & 10 & 4,5 & $60 \%$ & $100 \%$ & $90 \mathrm{~m}$ \\
\hline 3 & 10 & 6,0 & $60 \%$ & $100 \%$ & $90 \mathrm{~m}$ \\
\hline $4 \mathrm{a}$ & 15 & 3,0 & $60 \%$ & $100 \%$ & $90 \mathrm{~m}$ \\
\hline $4 \mathrm{~b}$ & 15 & 3,0 & $45 \%$ & $100 \%$ & $90 \mathrm{~m}$ \\
\hline $5 \mathrm{a}(\mathrm{básico})$ & 15 & 4,5 & $60 \%$ & $100 \%$ & $90 \mathrm{~m}$ \\
\hline $5 \mathrm{~b}$ & 15 & 4,5 & $45 \%$ & $100 \%$ & $90 \mathrm{~m}$ \\
\hline $5 \mathrm{c}$ & 15 & 4,5 & $60 \%$ & $80 \%$ & $90 \mathrm{~m}$ \\
\hline $5 \mathrm{~d}$ & 15 & 4,5 & $60 \%$ & $100 \%$ & $72 \mathrm{~m}$ \\
\hline $5 \mathrm{e}$ & 15 & 4,5 & $60 \%$ & $100 \%$ & $75 \mathrm{~m}$ \\
\hline $5 \mathrm{f}$ & 15 & 4,5 & $60 \%$ & $100 \%$ & $82,5 \mathrm{~m}$ \\
\hline $5 \mathrm{~g}$ & 15 & 4,5 & $60 \%$ & $100 \%$ & $97,5 \mathrm{~m}$ \\
\hline $6 \mathrm{a}$ & 15 & 6,0 & $60 \%$ & $100 \%$ & $90 \mathrm{~m}$ \\
\hline $6 \mathrm{~b}$ & 15 & 6,0 & $45 \%$ & $100 \%$ & $90 \mathrm{~m}$ \\
\hline $7 \mathrm{a}$ & 30 & 3,0 & $60 \%$ & $100 \%$ & $90 \mathrm{~m}$ \\
\hline $7 \mathrm{~b}$ & 30 & 3,0 & $45 \%$ & $100 \%$ & $90 \mathrm{~m}$ \\
\hline $8 \mathrm{a}$ & 30 & 4,5 & $60 \%$ & $100 \%$ & $90 \mathrm{~m}$ \\
\hline $8 \mathrm{~b}$ & 30 & 4,5 & $45 \%$ & $100 \%$ & $90 \mathrm{~m}$ \\
\hline $9 \mathrm{a}$ & 30 & 6,0 & $60 \%$ & $100 \%$ & $90 \mathrm{~m}$ \\
\hline $9 \mathrm{~b}$ & 30 & 6,0 & $45 \%$ & $100 \%$ & $90 \mathrm{~m}$ \\
\hline 10 & 15 & $5,0 \sim 3,3$ & $60 \%$ & $100 \%$ & $90 \mathrm{~m}$ \\
\hline
\end{tabular}

\subsection{AÇÕES E HIPOTESES DE CARREGAMENTOS}

\subsubsection{Peso próprio}

O peso próprio considerado em cada modelo depende da altura do tabuleiro e estão resumidos na tabela 3.4 .

Tabela 3.4 - Peso próprio da viga longitudinal e das transversinas.

\begin{tabular}{|c|c|c|c|}
\hline Modelos & $\begin{array}{c}\text { Altura do tabuleiro } \\
\mathrm{h}(\mathrm{m})\end{array}$ & $\begin{array}{c}\text { Peso linear da viga } \\
\text { celular }(\mathrm{kN} / \mathrm{m})\end{array}$ & $\begin{array}{c}\text { Transversinas } \\
(\mathrm{kN})\end{array}$ \\
\hline $1,4 \mathrm{a}, 4 \mathrm{~b}, 7 \mathrm{a}$ e $7 \mathrm{~b}$ & 3,0 & 215,35 & 153,00 \\
\hline $2,5 \mathrm{a}, 5 \mathrm{~b} \ldots$.. 5g, 8a e 8b & 4,5 & 259,60 & 230,10 \\
\hline $3,6 \mathrm{a}, 6 \mathrm{~b}, 9 \mathrm{a}$ e 9b & 6,0 & 304,60 & 297,45 \\
\hline 10 & $5,0 \sim 3,3$ & $274,60 \sim 223,60$ & 168,00 \\
\hline
\end{tabular}




\subsubsection{Revestimento e guarda rodas}

O revestimento possui $10 \mathrm{~cm}$ de espessura e foi adotado nas duas pistas de 6 $\mathrm{m}$ e no trecho central de $1,5 \mathrm{~m}$. Considerando o peso específico $(\gamma)$ igual a $24 \mathrm{kN} / \mathrm{m}^{3}$, temos um carregamento linear aplicado na viga longitudinal de $32,4 \mathrm{kN} / \mathrm{m}$.

Foram considerados quatro guarda-rodas, dois extremos e dois centrais que protegem os cabos, sendo o peso aproximado, de cada um, igual a $8,5 \mathrm{kN} / \mathrm{m}$.

\subsubsection{Carga variável}

A carga móvel foi adotada como sendo uma sobrecarga de multidão de valor igual a $5 \mathrm{kN} / \mathrm{m}^{2}$. Foi desconsiderado o carregamento de trem tipo TT-45 $5^{\mathrm{I}}$, pois o mesmo tem pouca influência frente à atuação da carga de multidão e com isso a análise se torna mais simples.

A disposição da carga variável deve ser escolhida de forma a obter os esforços (flexão, cortante, torção, normal, etc.) máximos e mínimos para cada seção analisada. Essa disposição, normalmente, é determinada através de linhas de influência para o esforço em questão, entretanto, em pontes com protensão no extradorso, devido ao alto grau de hiperestaticidade e a quantidade de parâmetros que influi nos esforços, a definição de tais linhas de influência seria muito trabalhosa e, para o estudo em questão, desnecessário. Em razão disso, buscou-se, por simplificação, estabelecer alguns casos de posição da carga variável que represente as situações críticas com uma boa aproximação.

A figura 3.6 mostra um procedimento que já foi adotado por diversos autores em estudos comparativos de pontes estaiadas, tais como WALTHER et al. (1999) e TORNERI (2002).

\footnotetext{
${ }^{\text {I }}$ O trem tipo TT-45 tem suas propriedades definidas pela Norma NBR7188 (1984) - Carga móvel em ponte rodoviária e passarela de pedestre.
} 


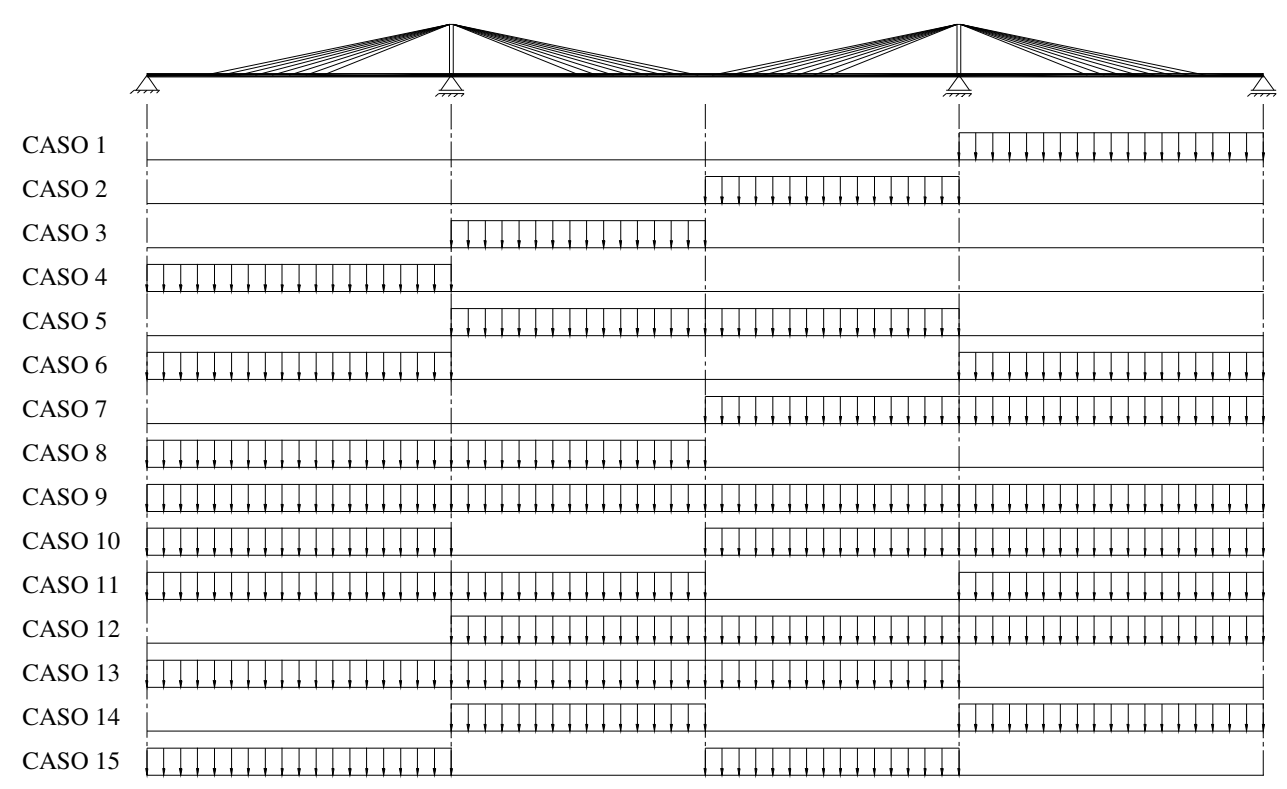

Figura 3.6 - Casos adotados de carregamento variável.

\subsection{DESCRIÇÃO DO PROCESSO DE ANÁLISE}

Por se tratar de pontes com vigas longitudinais celulares e apenas um plano de cabos (suspensão central), a estrutura de todos os casos em estudo foi representada por modelo de pórtico plano. As transversinas não foram discretizadas e o peso de cada uma foi aplicado na viga longitudinal.

As hipóteses adotadas para a disposição da carga variável têm por intuito estabelecer situações criticas de flexão no tabuleiro e na torre, além de esforços axiais nos tirantes. Não foram analisadas as solicitações tangenciais (cortante e torção).

A determinação da protensão necessária foi realizada por partes (figura 3.7). $\mathrm{Na}$ primeira fase, foi modelado apenas o trecho do tabuleiro partindo do apoio central (pelos dois lados) até a distancia do primeiro cabo que foi substituído por um apoio vertical. Na segunda fase, foram acrescidas duas aduelas de comprimento igual a $5 \mathrm{~m}$ em ambos os lados, o apoio correspondente ao primeiro cabo foi substituído pela reação obtida na primeira etapa e foi adotado um apoio vertical correspondente ao segundo cabo. As etapas seguintes foram realizadas com a mesma filosofia. 
ETAPA 1

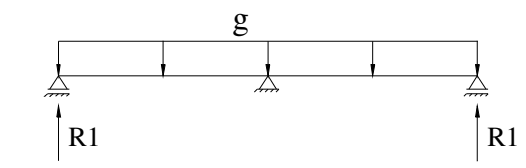

ETAPA 2

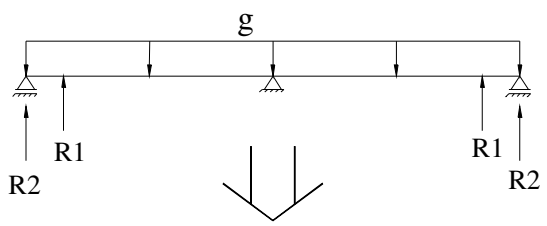

ETAPA 10

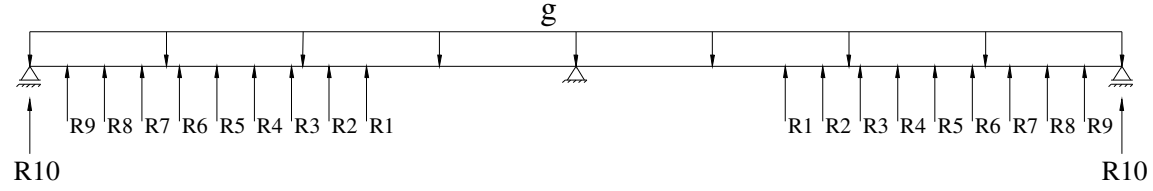

Figura 3.7 - Procedimento de cálculo da protensão em cada cabo.

De posse das reações (Ri) de cada apoio, em todas as etapas descritas, a protensão é calculada pela expressão:

$$
P_{i}=\frac{R_{i}}{\operatorname{sen} \alpha_{i}}
$$

sendo $\alpha_{\mathrm{i}} \mathrm{o}$ ângulo do cabo em relação a horizontal.

É importante observar que o procedimento de cálculo da protensão descrito compensaria as cargas permanentes apenas na etapa de construção e não após o seu término.

Além disso, a hipótese de compensação das cargas permanentes nas pontes com protensão no extradorso é praticamente impossível. No caso das pontes estaiadas, a existência de estais de ancoragem permite o controle dos possíveis movimentos das torres, de tal forma que a hipótese de deslocamento vertical nulo é facilmente satisfeita. Entretanto, nas pontes com protensão no extradorso, onde não existem esses tirantes de ancoragem, a obtenção de tal hipótese é difícil de controlar.

\subsubsection{Cálculo da protensão dos cabos no extradorso (modelo básico)}

Para o cálculo da protensão em cada cabo é necessário estabelecer a reação vertical, em cada etapa. 


\section{Etapa 1}

A primeira etapa consiste em considerar a construção do tabuleiro partindo do apoio intermediário até o ponto de inserção do primeiro cabo, ou seja, $28 \mathrm{~m}$ para cada lado. O esquema estrutural é mostrado na figura 3.8. Lembrando que o peso próprio do tabuleiro é $259,60 \mathrm{kN} / \mathrm{m}$, do revestimento é $32,40 \mathrm{kN} / \mathrm{m}$ e dos guardarodas é $34,00 \mathrm{kN} / \mathrm{m}(4 \times 8,50)$, somando um total de $326 \mathrm{kN} / \mathrm{m}$.

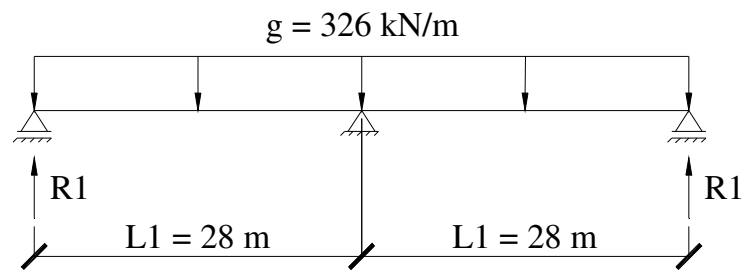

Figura 3.8 - Esquema estrutural da etapa 1.

Considerando a simetria da estrutura e do carregamento (figura 3.9) para facilitar os cálculos e resolvendo o modelo estrutural através de algum método conveniente (como o teorema dos trabalhos virtuais), obtemos o valor de $\mathrm{R}_{1}$ :

$$
R_{1}=\frac{3 g L_{1}}{8}=\frac{3 \cdot 326,00 \cdot 28}{8}=3423,00 \mathrm{kN}
$$

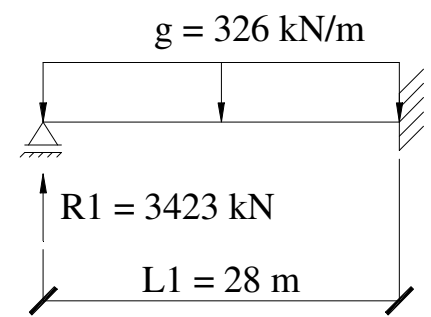

Figura 3.9 - Esquema estrutural da etapa 1 considerando a simetria.

\section{Etapa 2}

A segunda etapa consiste em considerar a execução de duas aduelas de $5 \mathrm{~m}$ (uma em cada extremidade), onde serão instalados mais dois cabos. Embora a protensão desses cabos modifique o valor da protensão daqueles já instalados, será admitido que isso não ocorre, ou seja, a componente vertical da protensão dos dois 
primeiros cabos permanece constante e igual a $3423,00 \mathrm{kN}$ que equivale à reação obtida na etapa 1. O esquema estrutural da segunda etapa é mostrado na figura 3.10.

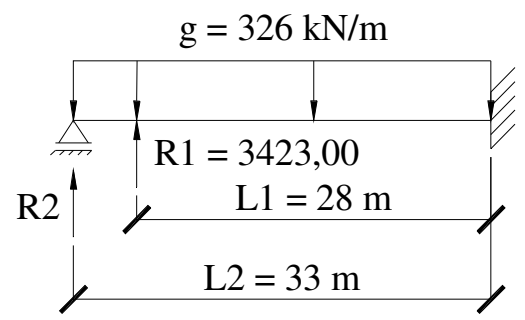

Figura 3.10 - Esquema estrutural da etapa 2 considerando a simetria.

Resolvendo o modelo estrutural temos:

$$
\begin{gathered}
R_{2}=\frac{3 g L_{2}}{8}-R_{1}\left[\frac{3}{2}\left(\frac{L_{1}}{L_{2}}\right)^{2}-\frac{1}{2}\left(\frac{L_{1}}{L_{2}}\right)^{3}\right] \\
R_{2}=\frac{3 \cdot 326,00 \cdot 33}{8}-3423,00\left[\frac{3}{2}\left(\frac{28}{33}\right)^{2}-\frac{1}{2}\left(\frac{28}{33}\right)^{3}\right]=1383,25 \mathrm{kN}
\end{gathered}
$$

\section{Etapa 3}

A terceira etapa tem a mesma filosofia da segunda etapa e o esquema estrutural é mostrado na figura 3.11.

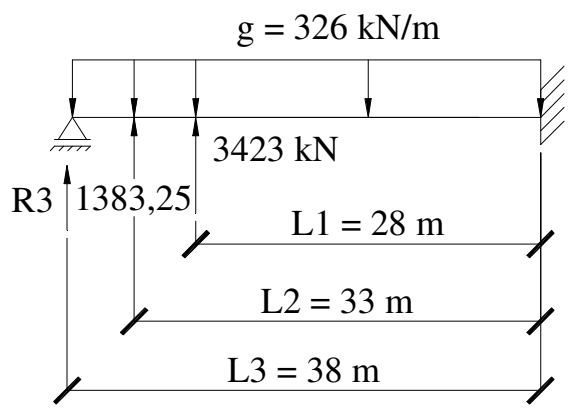

Figura 3.11 - Esquema estrutural da etapa 3 considerando a simetria.

Resolvendo a estrutura temos: 


$$
\begin{gathered}
R_{3}=\frac{3 g L_{3}}{8}-R_{1}\left[\frac{3}{2}\left(\frac{L_{1}}{L_{3}}\right)^{2}-\frac{1}{2}\left(\frac{L_{1}}{L_{3}}\right)^{3}\right]-R_{2}\left[\frac{3}{2}\left(\frac{L_{2}}{L_{3}}\right)^{2}-\frac{1}{2}\left(\frac{L_{2}}{L_{3}}\right)^{3}\right] \\
R_{3}=\frac{3 \cdot 326,00 \cdot 38}{8}-3423,00\left[\frac{3}{2}\left(\frac{28}{38}\right)^{2}-\frac{1}{2}\left(\frac{28}{38}\right)^{3}\right]-1383,250\left[\frac{3}{2}\left(\frac{33}{38}\right)^{2}-\frac{1}{2}\left(\frac{33}{38}\right)^{3}\right] \\
R_{3}=1430,68 \mathrm{kN}
\end{gathered}
$$

\section{Etapa j}

A etapa $\mathrm{j}$ é uma etapa genérica e o seu esquema estrutural é indicado na figura 3.12.

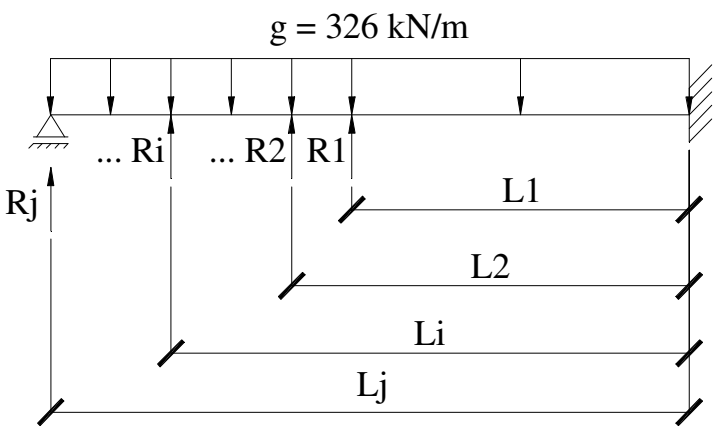

Figura 3.12 - Esquema estrutural da etapa j considerando a simetria.

Resolvendo o modelo estrutural temos:

$$
\begin{gathered}
R_{j}=\frac{3 g L_{j}}{8}, j=1 \\
R_{j}=\frac{3 g L_{j}}{8}-\sum_{i=1}^{j-1} R_{1}\left[\frac{3}{2}\left(\frac{L_{i}}{L_{j}}\right)^{2}-\frac{1}{2}\left(\frac{L_{i}}{L_{j}}\right)^{3}\right], j>1
\end{gathered}
$$

Após resolver as 10 etapas e de posse das forças verticais em cada ponto de inserção dos cabos no extradorso, o próximo passo é somar a essas valores o peso de uma transversina $(230,1 \mathrm{kN})$ e dividir o resultado pelo seno do ângulo que o cabo (correspondente a posição de cada força) faz com a linha horizontal. 
A tabela 3.5 mostra o valor da protensão em cada ponto, ressaltando que cada posição representa um grupo de quatro cabos no extradorso da ponte.

Tabela 3.5 - Protensão necessária nos cabos extradorsais.

\begin{tabular}{|c|c|c|c|c|c|c|c|}
\hline \multirow{2}{*}{ Posição } & $\mathrm{L}_{\mathrm{H}}$ & $\mathrm{L}_{\mathrm{V}}$ & $\operatorname{tg} \alpha$ & $\alpha$ & $\operatorname{sen} \alpha$ & $\mathrm{R}_{\mathrm{i}}$ & $\mathrm{P}$ \\
\cline { 2 - 7 } & $\mathrm{M}$ & $\mathrm{m}$ & & ${ }^{\circ}$ & & $\mathrm{kN}$ & $\mathrm{kN}$ \\
\hline 1 & 28 & 13,23 & 0,473 & 25,291 & 0,427 & 3653,10 & 8551,03 \\
\hline 2 & 33 & 13,63 & 0,413 & 22,442 & 0,382 & 1613,35 & 4226,20 \\
\hline 3 & 38 & 14,03 & 0,369 & 20,265 & 0,346 & 1660,78 & 4794,98 \\
\hline 4 & 43 & 14,43 & 0,336 & 18,551 & 0,318 & 1690,62 & 5313,98 \\
\hline 5 & 48 & 14,83 & 0,309 & 17,169 & 0,295 & 1711,51 & 5798,00 \\
\hline 6 & 53 & 15,23 & 0,287 & 16,032 & 0,276 & 1727,21 & 6253,90 \\
\hline 7 & 58 & 15,63 & 0,269 & 15,082 & 0,260 & 1739,58 & 6685,55 \\
\hline 8 & 63 & 16,03 & 0,254 & 14,276 & 0,247 & 1749,66 & 7095,50 \\
\hline 9 & 68 & 16,43 & 0,242 & 13,583 & 0,235 & 1758,07 & 7485,64 \\
\hline 10 & 73 & 16,83 & 0,231 & 12,983 & 0,225 & 1765,23 & 7857,52 \\
\hline
\end{tabular}

\subsubsection{Determinação da área de aço extradorsal (modelo básico)}

A figura 3.13 indica a numeração adotada para os cabos no extradorso (em todos os modelos).

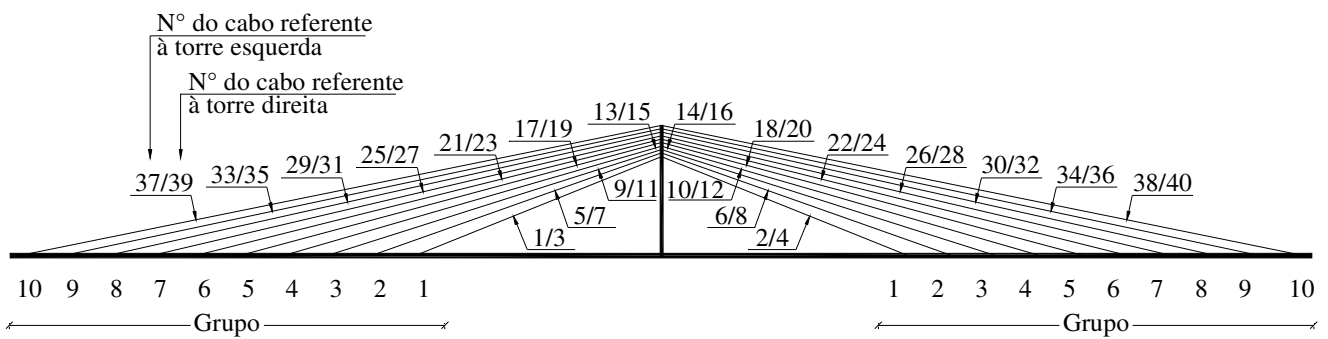

Figura 3.13 - Numeração genérica dos cabos no extradorso.

O procedimento adotado para o cálculo da área de cada cabo é iterativo e bem simples. O primeiro passo foi adotar um valor de tensão no ato da protensão para todos os cabos, por exemplo, $0,55 f_{\text {ptk }}(1045 \mathrm{MPa})$, a partir disso, podemos calcular a área de aço dividindo a protensão de cada cabo pela tensão adotada (tabela 3.6). 
Tabela 3.6 - Área de aço referente à tensão no ato da protensão igual a $1045 \mathrm{MPa}$.

\begin{tabular}{|c|c|c|c|c|c|c|c|}
\hline Grupo & Cabos & $\mathrm{A}_{\mathrm{p}}\left(\mathrm{cm}^{2}\right)$ & $\varepsilon$ & Grupo & Cabos & $\mathrm{A}_{\mathrm{p}}\left(\mathrm{cm}^{2}\right)$ & $\varepsilon$ \\
\hline 1 & 1 a 4 & 81,83 & $5,36 \mathrm{E}-03$ & 6 & 21 a 24 & 59,85 & $5,36 \mathrm{E}-03$ \\
\hline 2 & 5 a 8 & 40,44 & $5,36 \mathrm{E}-03$ & 7 & 25 a 28 & 63,98 & $5,36 \mathrm{E}-03$ \\
\hline 3 & 9 a 12 & 45,88 & $5,36 \mathrm{E}-03$ & 8 & 29 a 32 & 67,90 & $5,36 \mathrm{E}-03$ \\
\hline 4 & 13 a 16 & 50,85 & $5,36 \mathrm{E}-03$ & 9 & 33 a 36 & 71,63 & $5,36 \mathrm{E}-03$ \\
\hline 5 & 17 a 20 & 55,48 & $5,36 \mathrm{E}-03$ & 10 & 37 a 40 & 75,19 & $5,36 \mathrm{E}-03$ \\
\hline
\end{tabular}

Os cabos foram agrupados de quatro em quatro, pois além de possuírem a mesma protensão, eles têm obrigatoriamente a mesma área, uma vez que os tirantes simétricos em relação à torre pertencem ao mesmo cabo (desviado pela sela).

O passo seguinte foi resolver a estrutura no ADINA com as áreas obtidas na tabela 3.6, sendo que a protensão foi simulada através de deformações prévias. Então, comparam-se as tensões máximas (para as diversas combinações raras, figura 3.6), de cada grupo de cabos com a tensão admissível. Se todas essas tensões máximas estiverem dentro do intervalo [1138 MPa, $1142 \mathrm{MPa}$ ], isto é, $1140 \mathrm{MPa} \pm 2$ $\mathrm{MPa}$, é considerado que as áreas de aço obtidas são as desejadas, senão soma-se a diferença entre a tensão admissível e a máxima (de cada grupo) obtida pelo programa ao valor da tensão no ato da protensão, ou seja:

$$
\sigma_{p, \text { grupo }}{ }^{k+1}=\sigma_{p, \text { grupo }}{ }^{k}+\left(\sigma_{\text {adm }}-\sigma_{\text {máx, grupo }}{ }^{k}\right)
$$

após essa operação, repete-se o processo.

A tabela 3.7 mostra a determinação da área de aço para o modelo básico, sendo que foi necessária apenas uma iteração.

Tabela 3.7 - Determinação da área de aço necessária para o modelo básico.

\begin{tabular}{|c|c|c|c|c|c|c|c|c|}
\hline \multirow{2}{*}{ Grupo } & $\mathrm{P}$ & $\sigma_{\mathrm{p}}{ }^{0}$ & $\mathrm{~A}_{\mathrm{p}}{ }^{0}$ & $\sigma_{\text {máx }}{ }^{0}$ & $\sigma_{\text {adm }}-\sigma_{\text {máx }}{ }^{0}$ & $\sigma_{\mathrm{p}}{ }^{1}$ & $\mathrm{~A}_{\mathrm{p}}{ }^{1}$ & $\sigma_{\text {máx }}{ }^{1}$ \\
\cline { 2 - 9 } & $\mathrm{kN}$ & $\mathrm{MPa}$ & $\mathrm{cm}^{2}$ & $\mathrm{MPa}$ & $\mathrm{MPa}$ & $\mathrm{MPa}$ & $\mathrm{cm}^{2}$ & $\mathrm{MPa}$ \\
\hline 1 & 8551,03 & 1045 & 81,83 & 1121 & 19 & 1064 & 80,37 & 1141 \\
\hline 2 & 4226,20 & 1045 & 40,44 & 1117 & 23 & 1068 & 39,57 & 1141 \\
\hline 3 & 4794,98 & 1045 & 45,88 & 1111 & 29 & 1074 & 44,65 & 1141 \\
\hline 4 & 5313,98 & 1045 & 50,85 & 1106 & 34 & 1079 & 49,25 & 1139 \\
\hline 5 & 5798,00 & 1045 & 55,48 & 1102 & 38 & 1083 & 53,54 & 1139 \\
\hline 6 & 6253,90 & 1045 & 59,85 & 1100 & 40 & 1085 & 57,64 & 1139 \\
\hline 7 & 6685,55 & 1045 & 63,98 & 1100 & 40 & 1085 & 61,62 & 1139 \\
\hline 8 & 7095,50 & 1045 & 67,90 & 1099 & 41 & 1086 & 65,34 & 1141 \\
\hline 9 & 7485,64 & 1045 & 71,63 & 1099 & 41 & 1086 & 68,93 & 1141 \\
\hline 10 & 7857,52 & 1045 & 75,19 & 1099 & 41 & 1086 & 72,35 & 1141 \\
\hline
\end{tabular}




\section{RESULTADOS DO ESTUDO PARAMÉTRICO}

\subsection{CONSIDERAÇÕES INICIAIS}

Neste capítulo, os resultados obtidos a partir do processamento dos modelos definidos na tabela 3.3 foram comparados entre si.

No entanto, com o intuito de dar uma idéia do comportamento estrutural de uma ponte com protensão no extradorso, serão apresentados primeiramente os resultados obtidos através do processamento do modelo básico ${ }^{\text {II }}$.

\subsection{RESULTADOS DO PROCESSAMENTO DO MODELO BÁSICO}

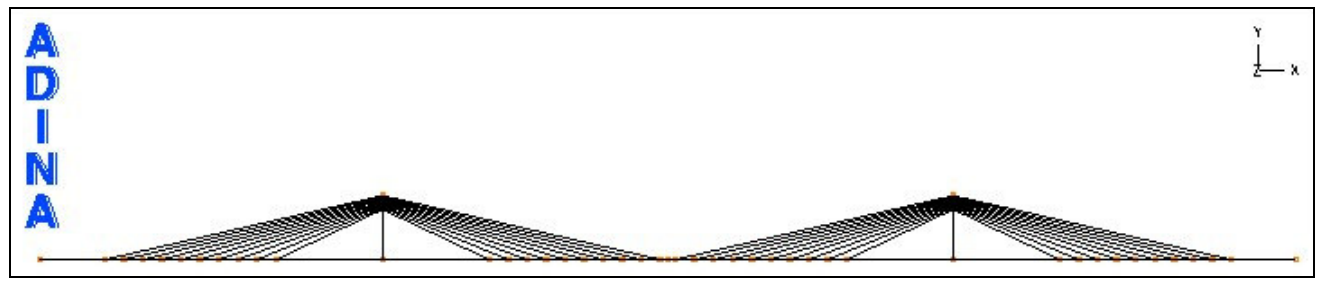

Figura 4.1 - Vista longitudinal do modelo básico (modelo 5a da tabela 3.3).

Na tabela 4.1, temos a protensão média, a tensão máxima e mínima, a área de aço e a flutuação de tensão de cada cabo no extradorso do modelo básico. Para a determinação das tensões máximas e mínimas, utilizou-se a combinação rara das ações cujos posicionamentos estão indicados na figura 3.6. Para a flutuação de tensão, foi considerada a combinação freqüente das ações com $\psi_{1}$ igual a 0,5 , embora a NBR8681 (2003) permita que, para vãos de $150 \mathrm{~m}, \psi_{1 \text { fad }}$ seja igual a 0,45.

\footnotetext{
II Alguns resultados do processamento dos outros modelos da tabela 3.3 podem ser vistos no anexo I.
} 
Tabela 4.1 - Protensão, tensão máxima e mínima, área de aço e flutuação de tensão dos cabos no extradorso do modelo básico.

\begin{tabular}{|c|c|c|c|c|c|c|}
\hline \multirow{2}{*}{\multicolumn{2}{|c|}{ Cabo }} & $\mathrm{P}$ & $\mathrm{A}_{\mathrm{p}}$ & $\sigma_{\text {máx }}$ & $\sigma_{\text {mín }}$ & $\Delta \sigma_{\mathrm{p}}$ \\
\hline & & $(\mathrm{kN})$ & $\left(\mathrm{cm}^{2}\right)$ & (MPa) & (MPa) & (MPa) \\
\hline 1 & 4 & \multirow{2}{*}{8551,03} & \multirow{2}{*}{80,37} & 1134 & 1070 & 32 \\
\hline 2 & 3 & & & 1141 & 1066 & 38 \\
\hline 5 & 8 & \multirow{2}{*}{4226,20} & \multirow{2}{*}{39,57} & 1136 & 1070 & 33 \\
\hline 6 & 7 & & & 1141 & 1068 & 37 \\
\hline 9 & 12 & \multirow{2}{*}{4794,98} & \multirow{2}{*}{44,65} & 1139 & 1073 & 33 \\
\hline 10 & 11 & & & 1141 & 1071 & 35 \\
\hline 13 & 16 & \multirow{2}{*}{5313,98} & \multirow{2}{*}{49,25} & 1139 & 1074 & 33 \\
\hline 14 & 15 & & & 1139 & 1073 & 33 \\
\hline 17 & 20 & \multirow{2}{*}{5798,00} & \multirow{2}{*}{53,54} & 1139 & 1075 & 32 \\
\hline 18 & 19 & & & 1137 & 1076 & 31 \\
\hline 21 & 24 & \multirow{2}{*}{6253,90} & \multirow{2}{*}{57,64} & 1139 & 1072 & 34 \\
\hline 22 & 23 & & & 1133 & 1076 & 29 \\
\hline 25 & 28 & \multirow{2}{*}{6685,55} & \multirow{2}{*}{61,62} & 1139 & 1065 & 37 \\
\hline 26 & 27 & & & 1126 & 1075 & 26 \\
\hline 29 & 32 & \multirow{2}{*}{7095,50} & \multirow{2}{*}{65,34} & 1141 & 1060 & 41 \\
\hline 30 & 31 & & & 1122 & 1076 & 23 \\
\hline 33 & 36 & \multirow{2}{*}{7485,64} & \multirow{2}{*}{68,93} & 1141 & 1053 & 44 \\
\hline 34 & 35 & & & 1115 & 1075 & 20 \\
\hline 37 & 40 & \multirow{2}{*}{7857,52} & \multirow{2}{*}{72,35} & 1141 & 1048 & 47 \\
\hline 38 & 39 & & & 1110 & 1073 & 19 \\
\hline \multicolumn{7}{|c|}{$\begin{array}{l}\sigma_{\text {máx, }} \sigma_{\text {mín }}-\text { Tensão máxima e mínima, respectivamente, } \\
\text { considerando a combinação rara das ações. } \\
\Delta \sigma_{p}-\text { Flutuação de tensão nos cabos considerando a combinação } \\
\text { freqüente das ações }\left(\psi_{1}=0,5\right) \text {. } \\
\text { Numeração dos cabos conforme figura } 3.13 \text {. }\end{array}$} \\
\hline
\end{tabular}

Algumas conclusões podem ser retiradas da tabela 4.1:

A flutuação de tensão máxima é de $47 \mathrm{MPa}$, correspondente aos cabos 37 e 40 que são os extremos (em relação à torre) de ambos os vãos laterais. Esse valor de flutuação é bastante próximo ao limite estabelecido no capítulo 2, o que mostra que os parâmetros adotados para o modelo básico estão de acordo com a definição de ponte com protensão no extradorso;

$>$ Os cabos com maior protensão e maior área de aço são aqueles mais próximos às torres. Isso se deve ao procedimento de cálculo estabelecido para a protensão associada à grande distância entre o primeiro cabo e a torre; 
$>$ A perda de rigidez dos cabos devido à sua curvatura foi analisada para os cabos extremos (37 e 40), que possuem o maior comprimento de projeção horizontal $\left(\mathrm{L}_{\mathrm{H}}=73 \mathrm{~m}\right)$. Foi adotada a tensão mínima, ao invés da média, que é igual a $1048 \mathrm{MPa}$ (conforme tabela 4.1). Com isso, através da expressão 3.1, temos:

$$
\frac{E^{*}}{E_{p}}=\frac{1}{1+\frac{78,5^{2} \cdot 73^{2} \cdot 195000}{12 \cdot 1048^{3}} \cdot 10^{-6}}=0,9995
$$

portanto, o valor da redução é pequeno e pode ser desprezado para as dimensões e os parâmetros aqui adotados.

As posições do carregamento variável que procovam as tensões máximas e mínimas são os casos 5 e 6 da figura 3.6, respectivamente. O momento máximo no vão lateral é produzido pelo caso 6, o máximo no vão central é pelo caso 5 e os momentos mínimos nos apoios intermediários pelos casos 12 (apoio direito) e 13 (apoio esquerdo).

A deformação da estrutura devido ao carregamento permanente (incluindo a protensão dos cabos) é apresentada na figura 4.2.

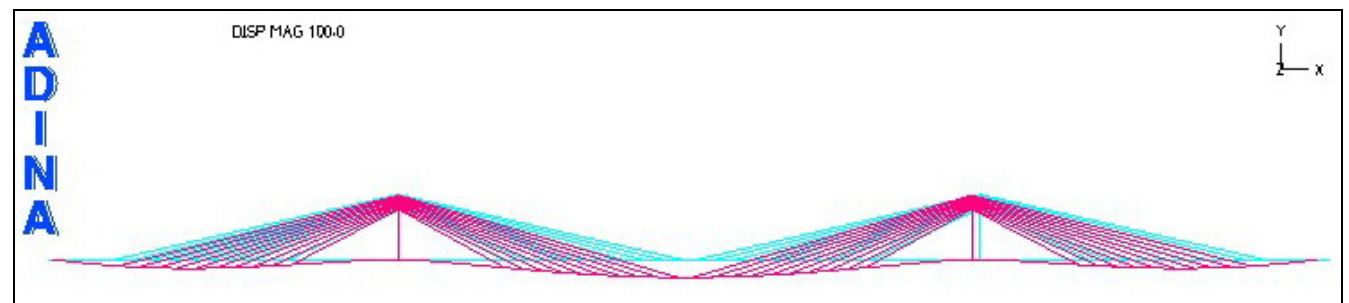

Figura 4.2 - Configuração original e deformada (ampliada 100 vezes) para o modelo básico, submetido ao carregamento permanente.

O deslocamento máximo (flecha) em virtude do carregamento permanente é de 4,6 centímetros no meio do vão principal.

A flecha (a), considerando o carregamento variável (valor integral), também ocorre no meio do vão e tem valor igual a $20,4 \mathrm{~cm}$, sendo que o caso de carregamento é o 5. A deformação da estrutura para o caso 5 de carregamento da figura 3.6 é mostrada na figura 4.3. 


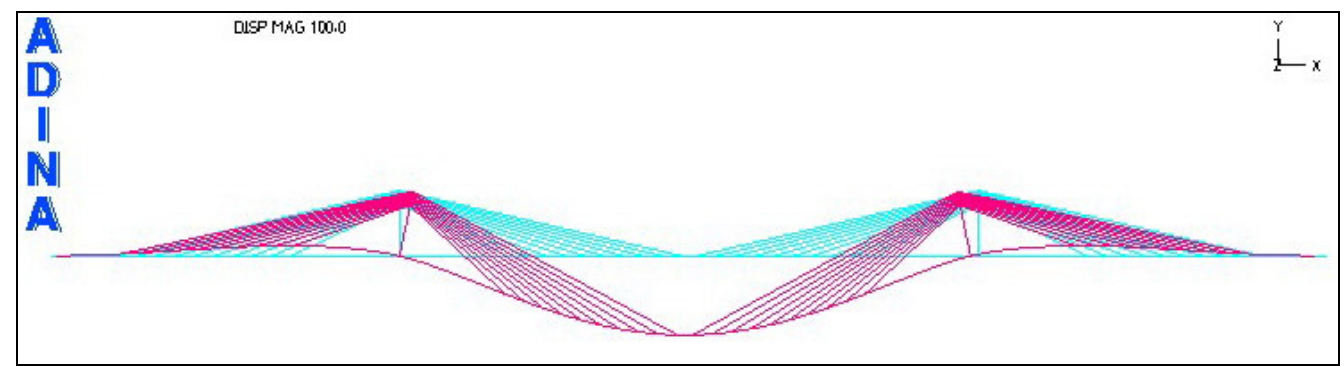

Figura 4.3 - Configuração original e deformada (ampliada 100 vezes) para o modelo básico, submetido ao carregamento 5 da figura 3.6.

O diagrama de momento fletor devido ao carregamento permanente e a envoltória do mesmo (para combinação rara) são mostrados na figura 4.4. Percebe-se que na região dos cabos 1 e 2 (e dos cabos 3 e 4 devido à simetria) existe um ponto anguloso no diagrama, isso ocorre pois a componente vertical destes cabos é, pelo menos, duas vezes a componente de qualquer outro cabo.

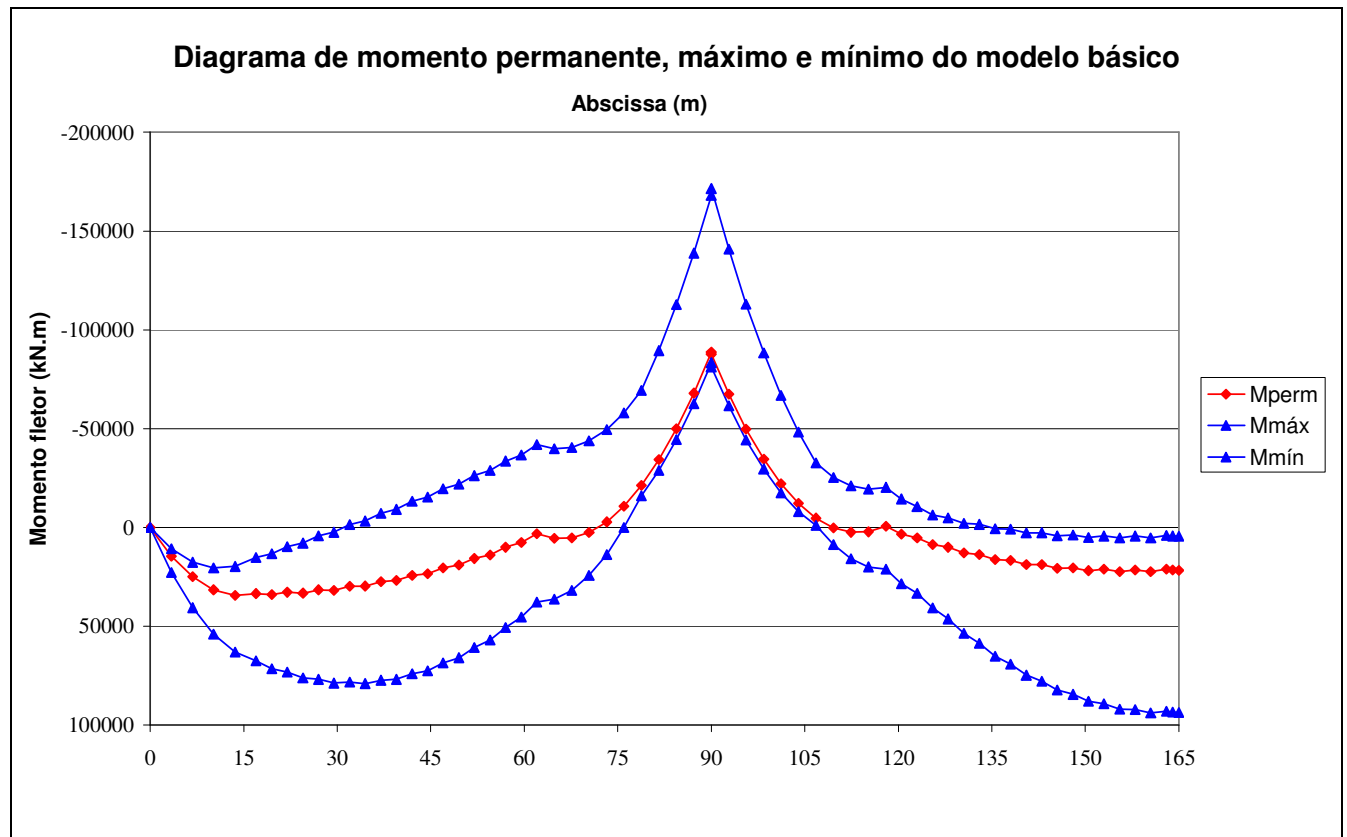

Figura 4.4 - Diagrama de momento fletor no tabuleiro devido ao carregamento permanente e envoltória de momento fletor (modelo básico).

O diagrama de esforço normal devido ao carregamento permanente e a envoltória do mesmo são apresentados na figura 4.5. Percebe-se que o diagrama de $\mathrm{N}_{\text {mín }}$ é bem próximo do diagrama de $\mathrm{N}_{\text {perm }}$, sendo a máxima redução igual a 2,57\% . 
Quanto ao diagrama de $\mathrm{N}_{\text {máx }}$, a diferença em relação à $\mathrm{N}_{\text {perm }}$ também não é grande, com aumento máximo de $6,12 \%$.

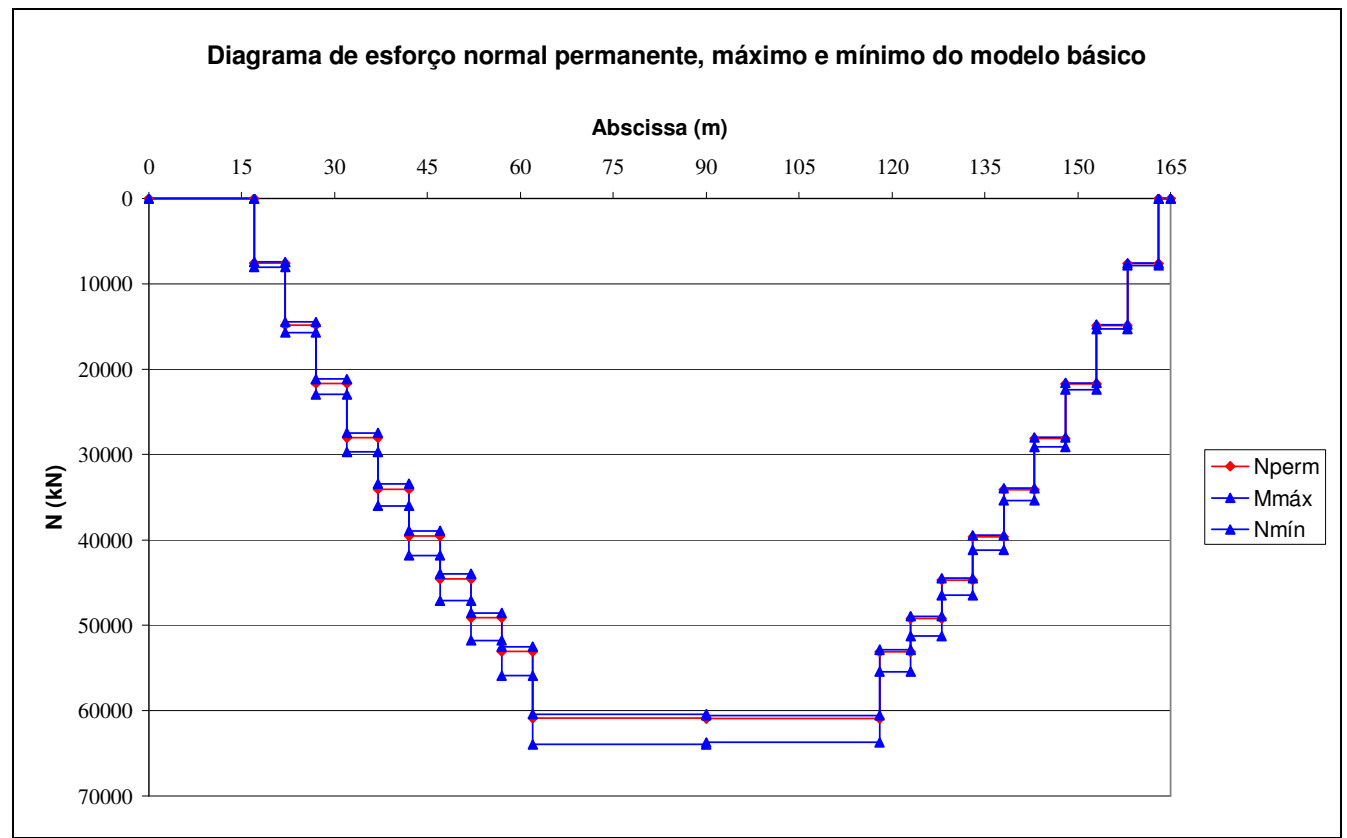

Figura 4.5 - Diagrama de esforço normal no tabuleiro devido ao carregamento permanente e envoltória de esforço normal (modelo básico).

\subsection{COMPORTAMENTO ESTRUTURAL AO VARIAR A ALTURA DA TORRE E A DO TABULEIRO}

Neste item serão comparados nove modelos que são: 1, 2, 3, 4a, 5a, 6a, 7a, $8 \mathrm{a}, 9 \mathrm{a}$.

\subsubsection{Influência sobre a protensão média, área de aço extradorsal e variação da flutuação de tensão nos cabos}

A tabela 4.2 mostra a protensão média, a área de aço extradorsal e a variação de tensão dos cabos ao variar a altura da torre e a altura do tabuleiro. 
Tabela 4.2 - Protensão média, área de aço extradorsal e variação de tensão dos cabos ao variar a altura da torre e a altura do tabuleiro.

\begin{tabular}{|c|c|c|c|c|c|}
\hline \multirow{2}{*}{ Modelo } & $\mathrm{H}$ & $\mathrm{h}$ & $\mathrm{P}_{\text {média }}$ & $\mathrm{A}_{\mathrm{p}, \text { total }}$ & $\Delta \sigma_{\mathrm{p}, \text { máx }}$ \\
\cline { 2 - 7 } & $(\mathrm{m})$ & $(\mathrm{m})$ & $(\mathrm{kN})$ & $\left(\mathrm{cm}^{2}\right)$ & $(\mathrm{Mpa})$ \\
\hline 1 & 10 & 3,0 & 8373,65 & 3191,00 & 76 \\
\hline 2 & 10 & 4,5 & 9348,72 & 3356,36 & 37 \\
\hline 3 & 10 & 6,0 & 10214,35 & 3586,96 & 21 \\
\hline $4 \mathrm{a}$ & 15 & 3,0 & 5598,00 & 2231,92 & 95 \\
\hline $5 \mathrm{a}$ & 15 & 4,5 & 6406,23 & 2372,96 & 47 \\
\hline $6 \mathrm{a}$ & 15 & 6,0 & 6203,28 & 2563,80 & 26 \\
\hline $7 \mathrm{a}$ & 30 & 3,0 & 3100,45 & 1299,56 & 133 \\
\hline $8 \mathrm{a}$ & 30 & 4,5 & 3635,67 & 1399,80 & 68 \\
\hline 9a & 30 & 6,0 & 4146,96 & 1529,04 & 39 \\
\hline $\mathrm{A}_{\mathrm{p}, \text { total }}-$ Área total de aço de protensão extradorsal. \\
$\Delta \sigma_{\mathrm{p}, \text { máx }}-$ Flutuação máxima de tensão nos tirantes para CF $\left(\psi_{1}=0,5\right)$. \\
\hline
\end{tabular}

A partir dos dados da tabela 4.2 é possível obter as seguintes conclusões:

$>$ Quanto maior a altura da torre e menor a altura do tabuleiro, menor a quantidade de aço necessária (figura 4.6). No entanto, percebe-se que a influência da altura do tabuleiro é muito pequena em relação à altura da torre. Por exemplo: ao aumentar a torre de $15 \mathrm{~m}(\mathrm{~L} / 10)$ para $30 \mathrm{~m}(\mathrm{~L} / 5)$, considerando a altura do tabuleiro igual a 4,5 m (L/33), há uma redução de $41 \%$ na área de aço e $43 \%$ na protensão média. Enquanto que ao diminuir a altura do tabuleiro de $6 \mathrm{~m}(\mathrm{~L} / 25)$ para $3 \mathrm{~m}$ (L/50) considerando a altura da torre igual a $15 \mathrm{~m}(\mathrm{~L} / 10)$, a redução na área de aço é de apenas $13 \%$;

Essa relação inversa entre a altura da torre e seu efeito sobre a área de aço e, também, sobre a protensão média (figura 4.6), se deve à menor ou maior eficiência dos tirantes em obter a resultante vertical da protensão estabelecida; 


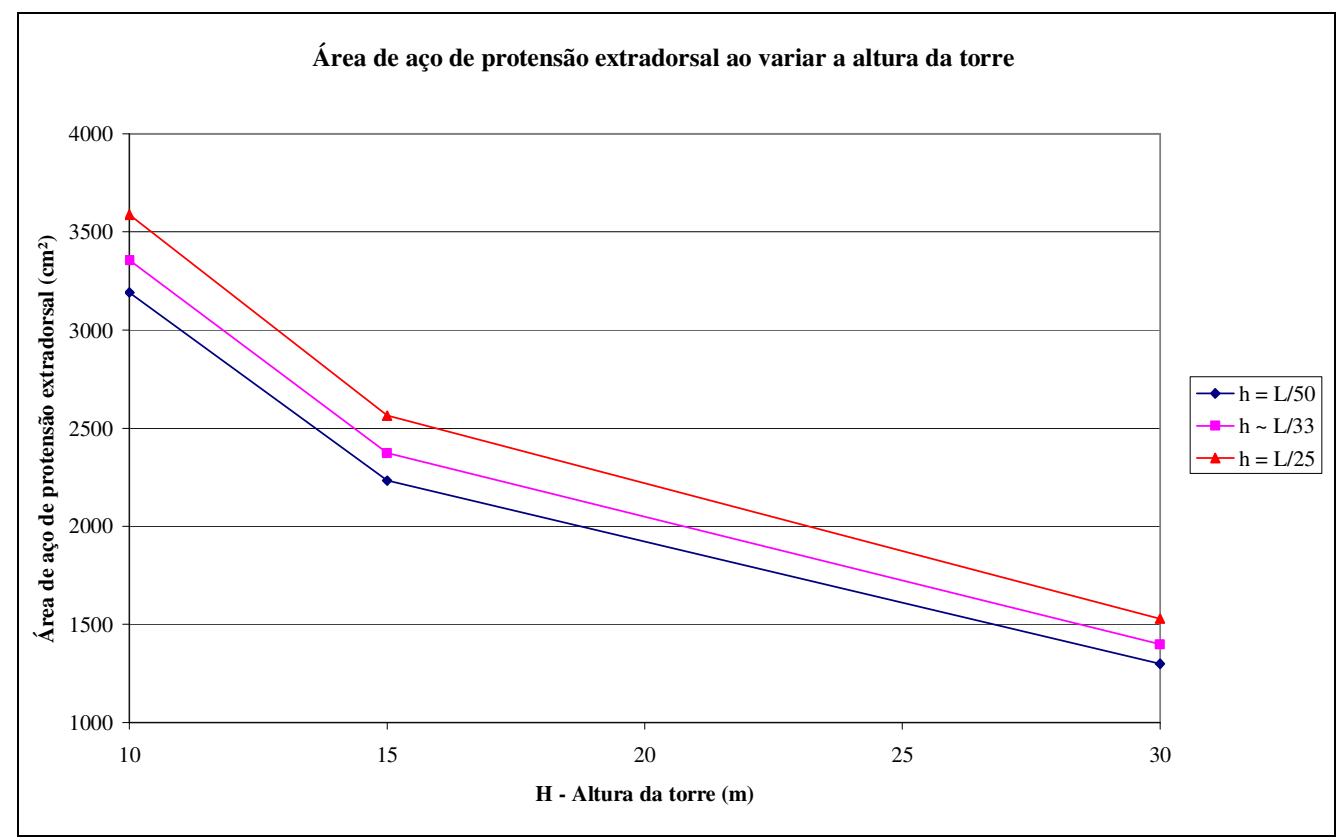

Figura 4.6 - Área de aço de protensão extradorsal necessária ao variar a altura da torre.

Em todos os casos analisados, os cabos com maior flutuação de tensão foram os mesmos do modelo básico (cabos 37 e 40);

$>$ Quanto maior a altura do tabuleiro e menor a altura da torre, menor a flutuação de tensão máxima nos cabos (figura 4.7). Contudo, percebe-se que a influência da altura da torre é menor que a da altura do tabuleiro. Por exemplo: ao variar h de $3 \mathrm{~m}$ (L/50) para 4,5 m (L/33), mantendo $\mathrm{H}$ em 15 m (L/10), a flutuação de tensão reduz em $51 \%$, se a variação for para h igual a $6 \mathrm{~m}(\mathrm{~L} / 25)$ essa redução passa para $73 \%$, enquanto que ao reduzir $\mathrm{H}$ de $30 \mathrm{~m}(\mathrm{~L} / 5)$ para $10 \mathrm{~m}$ (L/15), mantendo h em 4,5 m (L/33), a redução é de $46 \%$;

> Pelo critério de segurança à fadiga adotado, observa-se que para altura de torre igual a $\mathrm{L} / 15$ a altura do tabuleiro pode chegar a aproximadamente L/37, o que está bastante próximo da proposta de MATHIVAT (1988). No caso de altura de torre igual a L/10 esse valor aumenta para L/34 e para $\mathrm{H}$ igual a $\mathrm{L} / 5$ passa a ser $\mathrm{L} / 27$; 


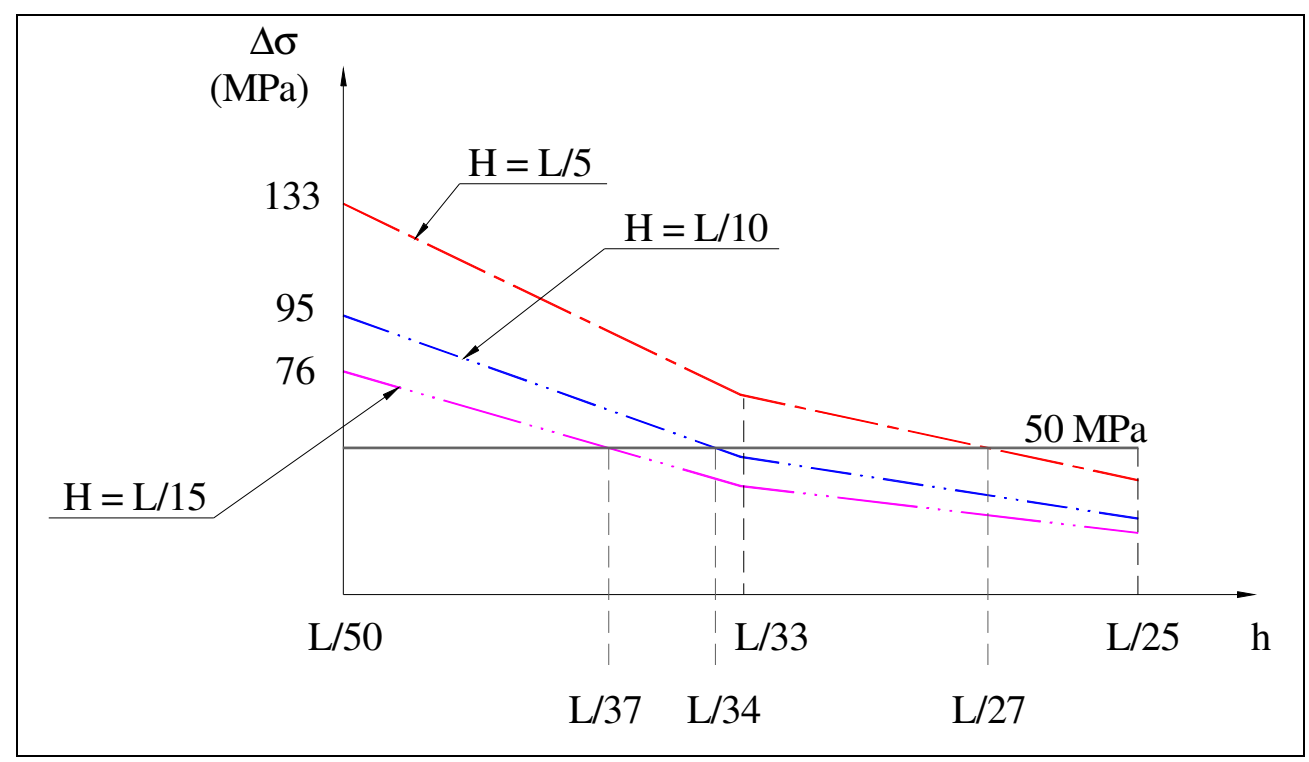

Figura 4.7 - Flutuação de tensão máxima dos cabos no extradorso ao variar a altura do tabuleiro.

De acordo com a conclusão de que para altura de torre igual a L/5, a altura do tabuleiro precisa ser no mínimo igual a L/27, podemos perceber o porquê das pontes com protensão no extradorso não possuirem torres comuns às pontes estaiadas. Não parece razoável que ao invés de usar uma solução estaiada com altura de tabuleiro em torno de L/100, aplique-se uma solução com protensão extradorsal com altura igual a L/27, o aumento considerável de material não compensa a redução dos custos do sistema de protensão.

\subsubsection{Influência sobre as solicitações normais e as flechas imediatas no tabuleiro}

A tabela 4.3 mostra o efeito da variação da altura do tabuleiro e da torre nos momentos fletores máximos no vão lateral e no meio do vão central, o momento mínimo no apoio intermediário, além dos esforços normais máximos (considerando o sinal positivo como sendo compressão) e flechas imediatas no tabuleiro. 
Tabela 4.3 - Alguns esforços no tabuleiro ao variar a altura da torre e a altura do tabuleiro.

\begin{tabular}{|c|c|c|c|c|c|c|c|}
\hline \multirow{3}{*}{ Modelo } & \multirow{2}{*}{$\mathrm{H}$} & \multirow{2}{*}{$\mathrm{h}$} & \multirow{2}{*}{$\mathrm{N}_{\text {máx }}$} & Vão lateral & Apoio int. & Vão central & \multirow{2}{*}{$a$} \\
\hline & & & & $\mathrm{M}_{\text {máx }}$ & $\mathrm{M}_{\mathrm{mín}}$ & $\mathbf{M}_{\text {máx }}$ & \\
\hline & $\mathrm{m}$ & $\mathrm{m}$ & $\mathrm{kN}$ & kN.m & kN.m & kN.m & $\mathrm{cm}$ \\
\hline 1 & 10 & 3,0 & 88316,4 & 74369,5 & -154575 & 87183,8 & 47,8 \\
\hline 2 & 10 & 4,5 & 93228,7 & 81086,7 & -187362 & 105088,0 & 22,8 \\
\hline 3 & 10 & 6,0 & 99414,6 & 86493,9 & -209286 & 115042,0 & 12,7 \\
\hline $4 a$ & 15 & 3,0 & 59976,4 & 71638,9 & -133439 & 72937,0 & 40,0 \\
\hline $5 a$ & 15 & 4,5 & 63978,2 & 78978,4 & -171505 & 93543,8 & 20,4 \\
\hline $6 a$ & 15 & 6,0 & 69030,8 & 84740,1 & -196912 & 106189,0 & 11,8 \\
\hline $7 a$ & 30 & 3,0 & 30840,3 & 68820,3 & -110256 & 55182,6 & 30,7 \\
\hline $8 \mathrm{a}$ & 30 & 4,5 & 33291,2 & 76222,2 & -151603 & 77971,4 & 17,1 \\
\hline $9 a$ & 30 & 6,0 & 36281,8 & 82543,6 & -181049 & 93298,8 & 10,4 \\
\hline
\end{tabular}

A partir dos dados da tabela 4.3 é possível obter as seguintes conclusões:

Quanto menor a altura do tabuleiro e maior a altura da torre, menores os momentos fletores máximos, em módulo, no vão lateral, no apoio intermediário e no meio do vão;

$>$ O momento máximo no vão lateral varia relativamente pouco ao variar a altura da torre ou a altura do tabuleiro, embora este último seja mais influente. Por exemplo: ao variar $\mathrm{H}$ de $\mathrm{L} / 5$ para $\mathrm{L} / 15$, com h igual a L/33, o acréscimo gerado é de apenas 6,3\% e ao aumentar h de L/50 para L/25, com $\mathrm{H}$ igual a L/10, o acréscimo é de $18 \%$;

$>$ No caso do momento mínimo sobre o apoio, a altura do tabuleiro é o parâmetro que mais tem influência. Por exemplo: ao diminuir a torre de L/5 para L/15, considerando h igual a L/33, há um acréscimo de 23,6\%, enquanto que ao aumentar o tabuleiro de L/50 para L/25 considerando $\mathrm{H}$ igual a L/10, há um acréscimo de 47\%. É interessante observar que a variação do momento em relação à altura do tabuleiro é praticamente linear, independente da altura da torre (figura 4.8);

No caso do momento máximo no meio do vão central, tanto a altura da torre, quanto a altura do tabuleiro têm relativa influência sobre o mesmo (figura 4.9). 


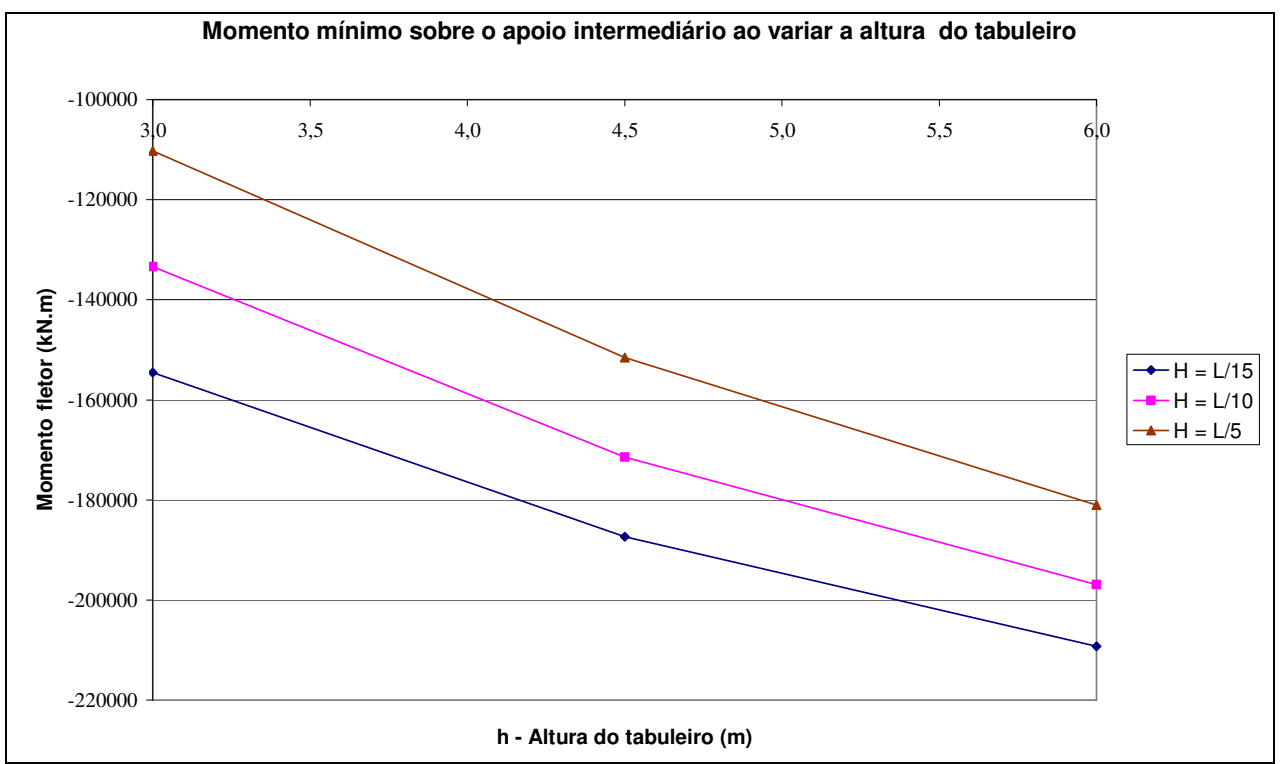

Figura 4.8 - Momento fletor mínimo sobre o apoio intermediário ao variar a altura do tabuleiro.

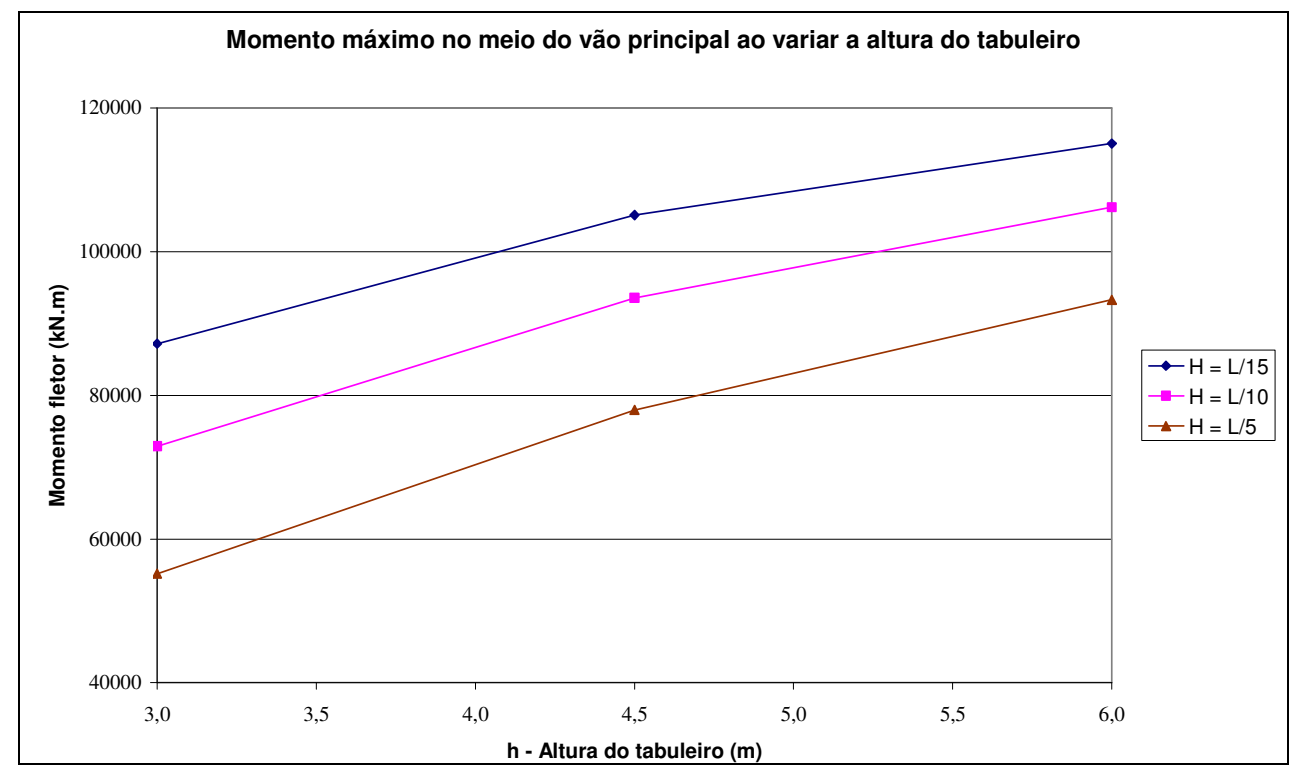

Figura 4.9 - Momento fletor máximo no meio do vão central ao variar a altura do tabuleiro.

As figuras 4.10 e 4.11 apresentam os diagramas de momento permanente ao variar a altura do tabuleiro, considerando a altura da torre igual a L/10 ${ }^{\mathrm{III}}$, e ao variar a altura da torre, considerando a altura do tabuleiro igual a $\mathrm{L} / 33^{\mathrm{IV}}$, respectivamente.

${ }^{\text {III }}$ Os diagramas de momento fletor permanente ao variar a altura do tabuleiro, considerando a altura de torre igual $\mathrm{L} / 15 \mathrm{e} \mathrm{L/5}$ podem ser vistos no anexo II.

IV Os diagramas de momento fletor permanente ao variar a altura da torre, considerando a altura do tabuleiro igual L/50 e L/25 podem ser vistos no anexo II. 


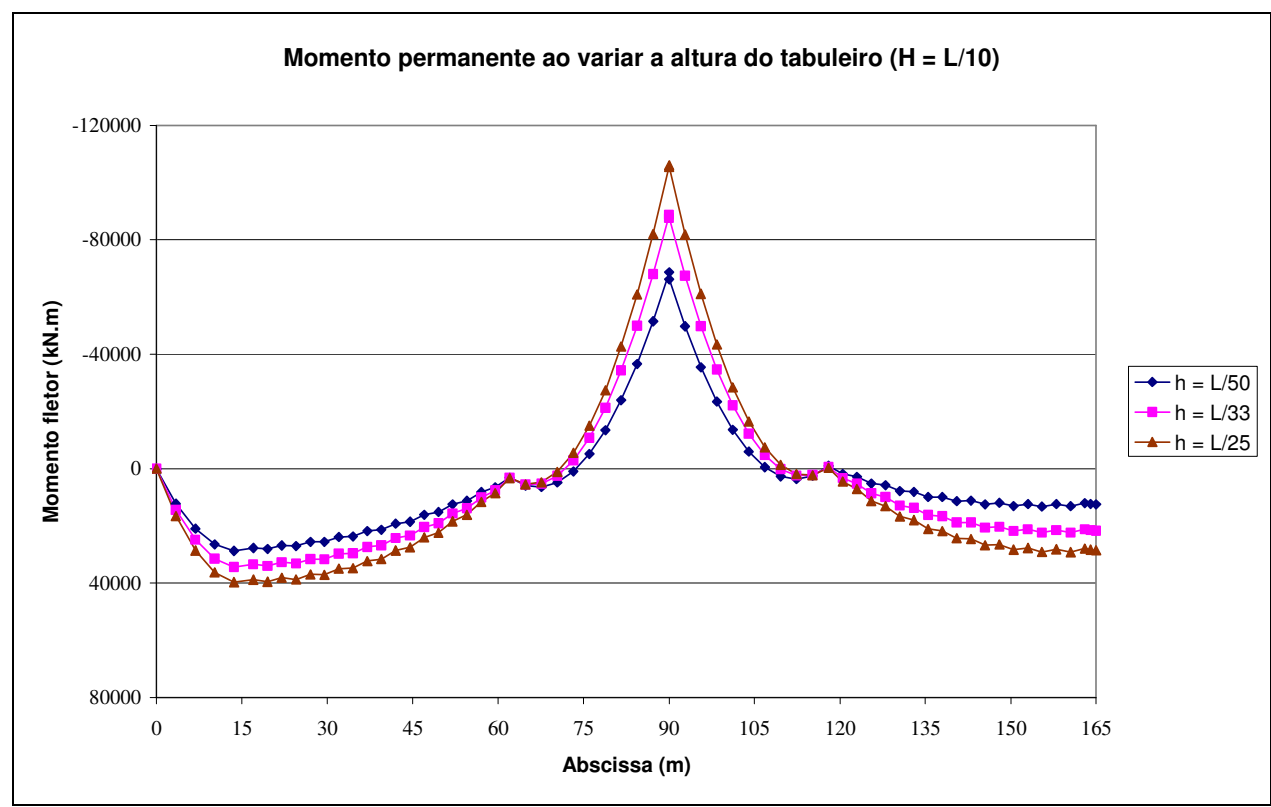

Figura 4.10 - Diagramas de momento fletor permanente ao variar a altura do tabuleiro, considerando a altura da torre igual a $15 \mathrm{~m}(\mathrm{~L} / 10)$.

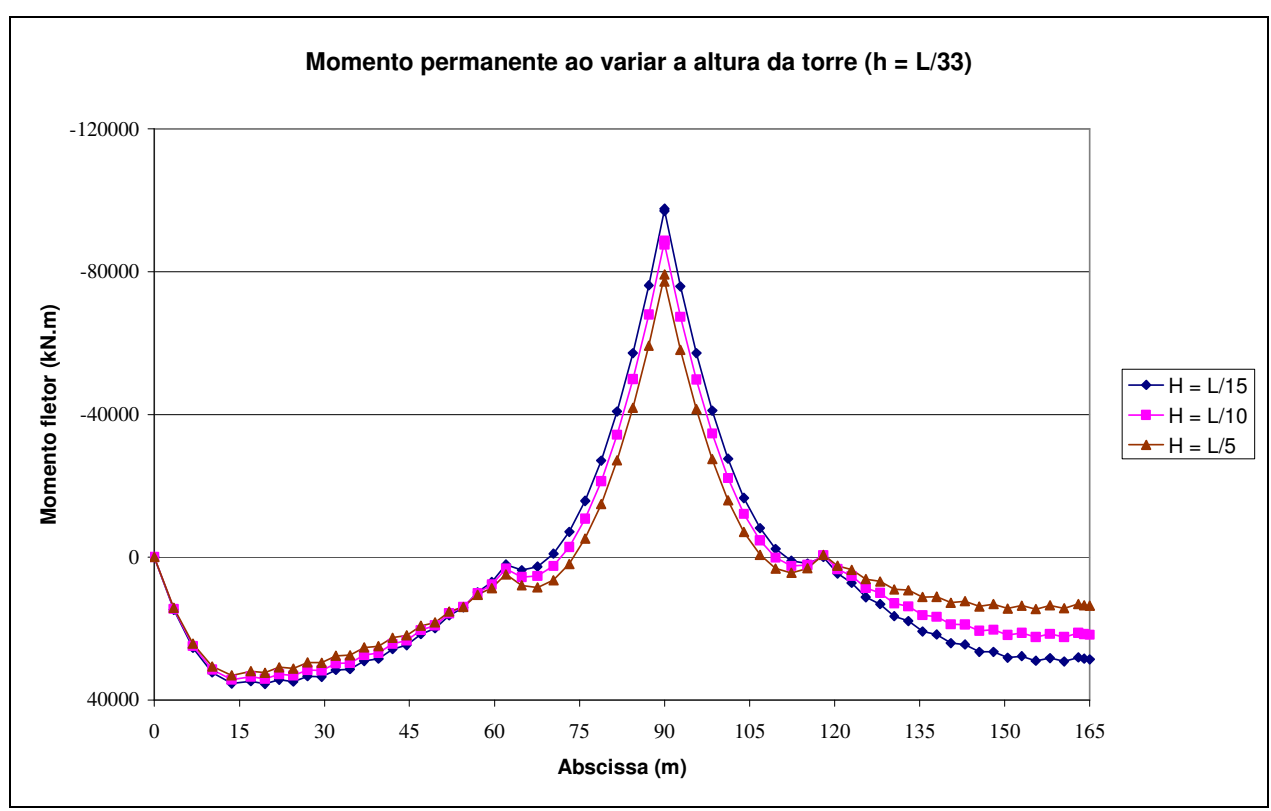

Figura 4.11 - Diagramas de momento fletor permanente ao variar a altura da torre, considerando a altura do tabuleiro igual a $4,5 \mathrm{~m}(\mathrm{~L} / 33)$.

A figura 4.12 mostra a envoltória de momento fletor ao variar a altura do tabuleiro, considerando a altura da torre igual a $15 \mathrm{~m}(\mathrm{~L} / 10)^{\mathrm{V}}$.

\footnotetext{
${ }^{\mathrm{V}}$ As envoltórias de momento fletor ao variar a altura do tabuleiro, considerando a altura de torre igual a $10 \mathrm{~m}(\mathrm{~L} / 15)$ e $30 \mathrm{~m}(\mathrm{~L} / 5)$ podem ser vistas no anexo II.
} 


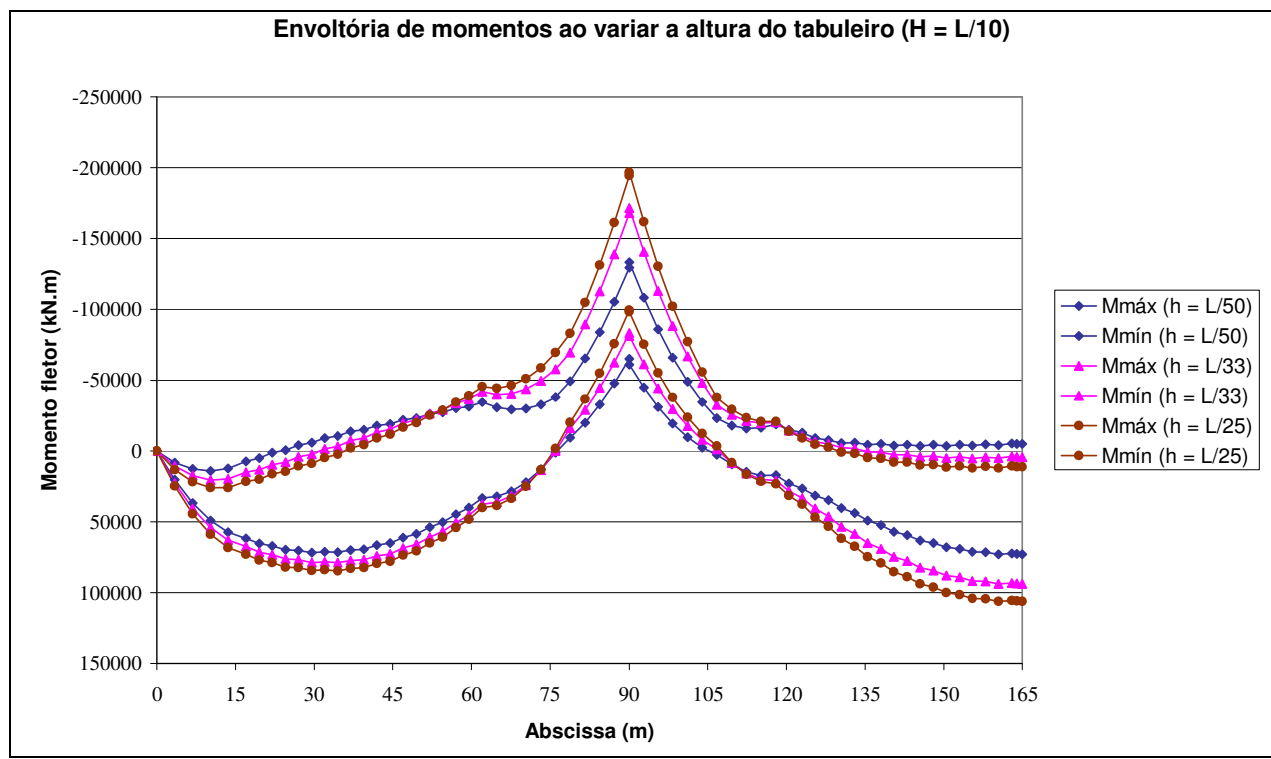

Figura 4.12 - Envoltória de momento fletor (combinação rara) ao variar a altura do tabuleiro, considerando a altura da torre igual a $15 \mathrm{~m}(\mathrm{~L} / 10)$.

A figura 4.13 mostra as envoltórias de momento fletor ao variar a altura da torre, considerando a altura do tabuleiro igual a $4,5 \mathrm{~m}(\mathrm{~L} / 33)^{\mathrm{VI}}$.

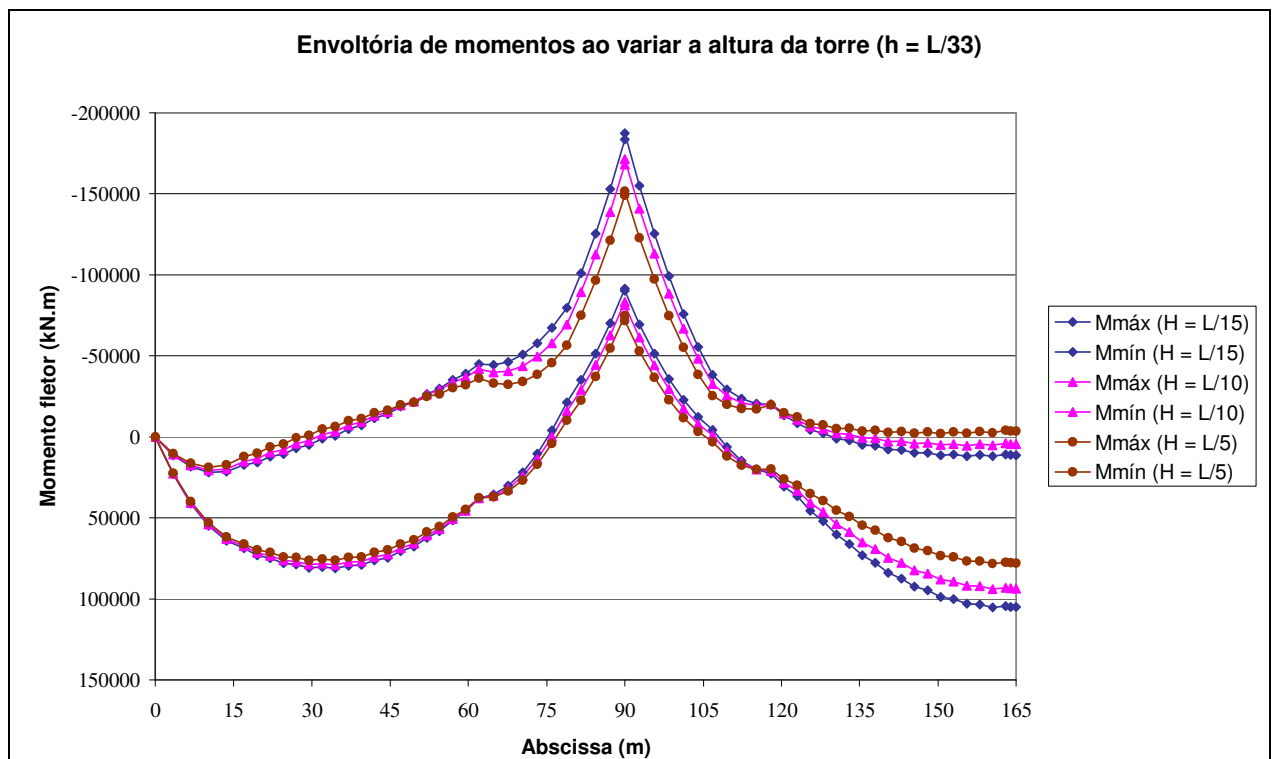

Figura 4.13 - Envoltória de momento fletor ao variar a altura da torre $(\mathrm{h}=\mathrm{L} / 33)$.

Com relação ao esforço normal máximo no tabuleiro, o comportamento é similar ao da protensão média e da área de aço necessária, ou seja, quanto maior a altura da torre e menor a altura do tabuleiro, menor a normal máxima (figura 4.14).

\footnotetext{
${ }^{\mathrm{VI}}$ As envoltórias de momento fletor ao variar a altura da torre, considerando a altura do tabuleiro igual a $3 \mathrm{~m}(\mathrm{~L} / 50)$ e $6 \mathrm{~m}(\mathrm{~L} / 25)$ podem ser vistas no anexo II.
} 


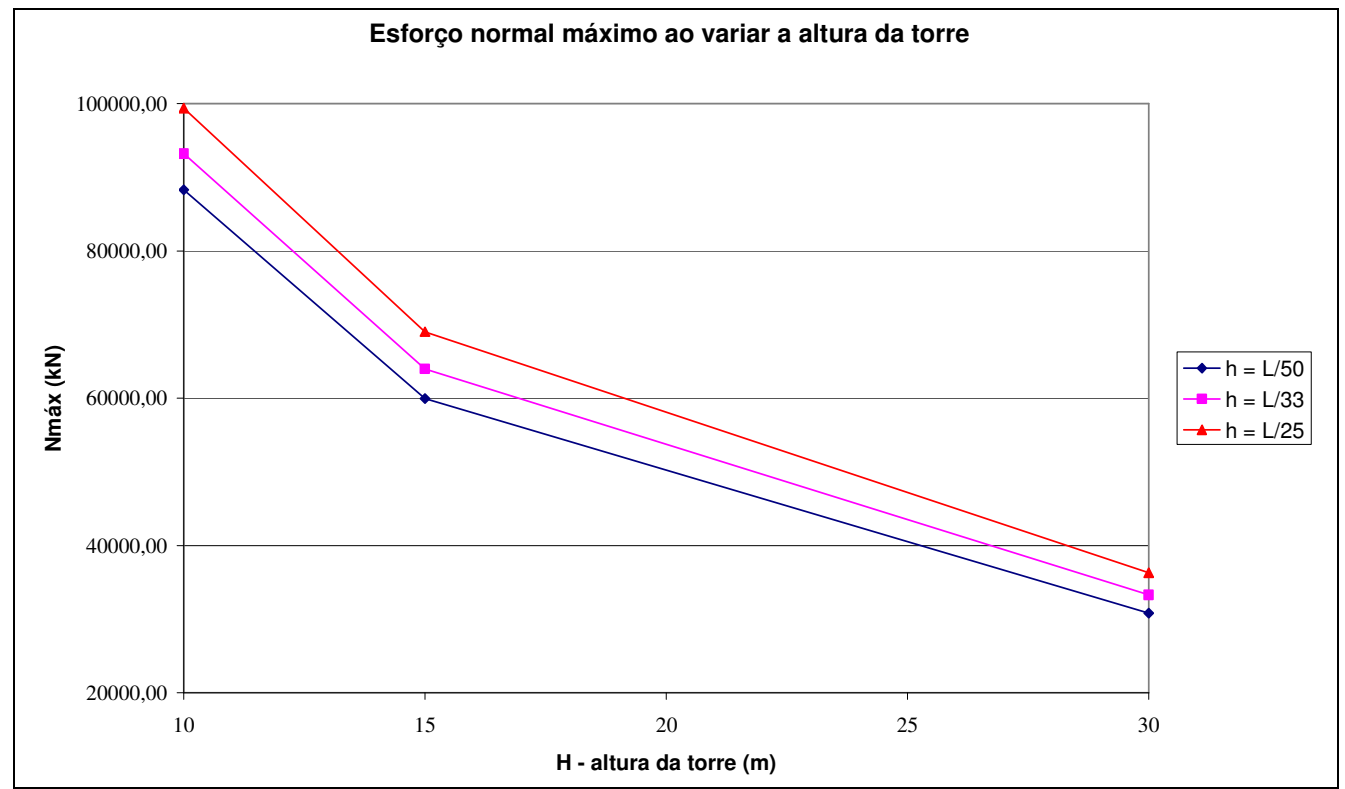

Figura 4.14 - Esforço normal máximo no tabuleiro ao variar a altura da torre.

Em referência à flecha imediata $(a)$, quanto maiores forem as alturas da torre e do tabuleiro, menor a flecha (figura 4.15). Isso ocorre, pois quanto maior for a rigidez do tabuleiro ou do sistema de cabos, menor é a deformabilidade da ponte. Em todos os casos analisados, a combinação de carregamento variável que provoca tal deslocamento vertical é o caso 5 da figura 3.6.

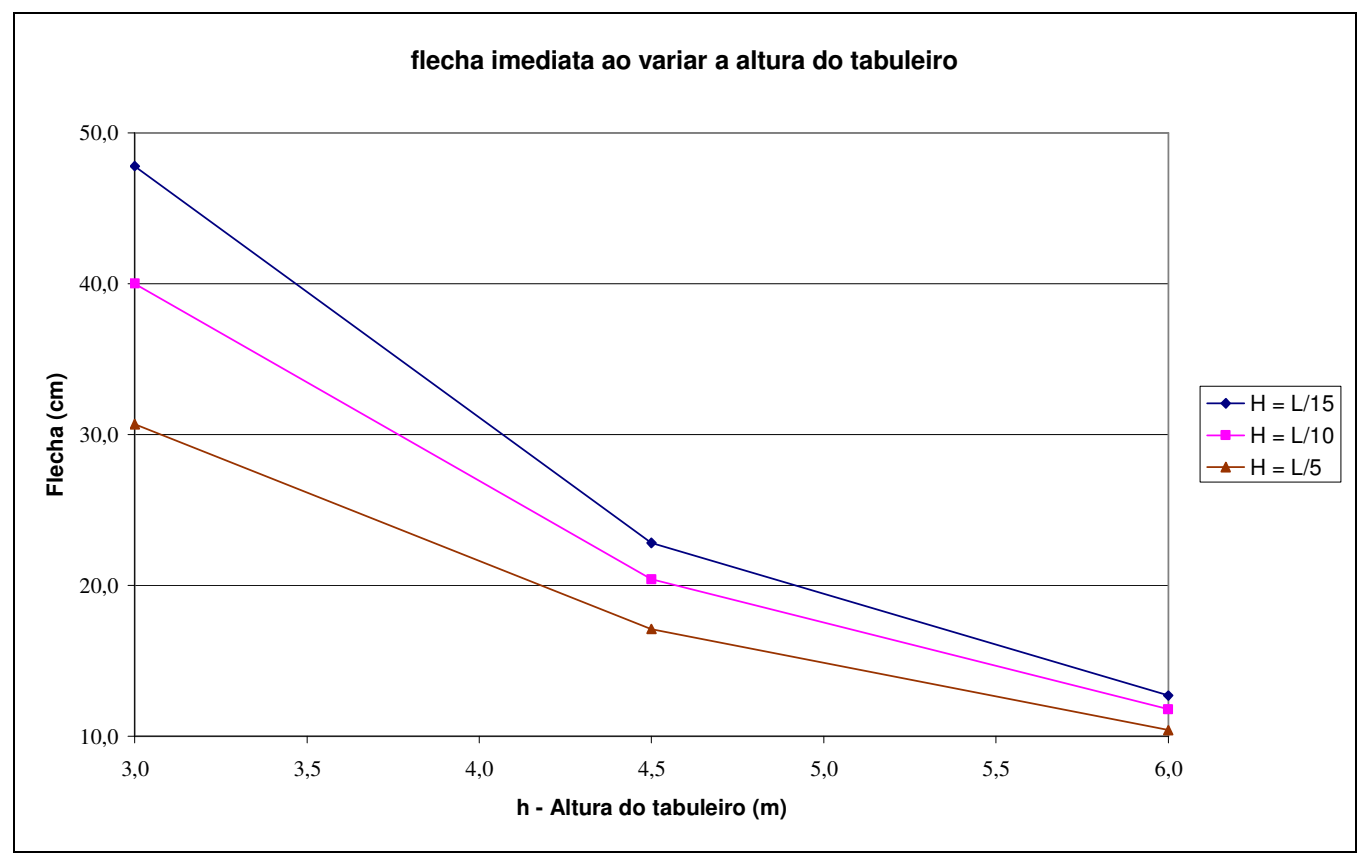

Figura 4.15 - Flecha imediata do tabuleiro ao variar a sua altura. 
Analisando o pré-dimensionamento definido pelo critério de fadiga dos cabos no extradorso (item 4.3.1) e levando em conta o efeito da variação da altura da torre e do tabuleiro nas solicitações normais e na área de aço extradorsal, pode-se concluir que é bastante razoável utilizar a torre com altura igual a L/10. Uma vez que a altura mínima, em relação a $\mathrm{H}=\mathrm{L} / 15$, não aumenta consideravelmente e a área de aço e as solicitações normais no tabuleiro são reduzidas.

\subsection{COMPORTAMENTO ESTRUTURAL AO MODIFICAR O NÍVEL DE TENSÃO DOS CABOS NO EXTRADORSO}

Neste item serão comparados os modelos: 4a e 4b; 5a e 5b; 6a e 6b; 7a e 7b; $8 a$ e $8 b ; 9 a$ e $9 b$.

\subsubsection{Influência sobre a área de aço extradorsal e variação da flutuação de tensão nos cabos}

Tabela 4.4 - Área de aço extradorsal e flutuação de tensão nos tirantes ao variar a tensão admissível dos cabos.

\begin{tabular}{|c|c|c|c|c|c|c|}
\hline \multirow{2}{*}{ Modelo } & $\mathrm{H}$ & $\mathrm{h}$ & $\sigma_{\mathrm{adm}}$ & $\mathrm{A}_{\mathrm{p}, \text { total }}$ & Peso de aço & $\Delta \sigma_{\mathrm{p}, \text { máx }}$ \\
\cline { 2 - 7 } & $(\mathrm{m})$ & $(\mathrm{m})$ & $\% f_{p t k}$ & $\left(\mathrm{~cm}^{2}\right)$ & $($ Ton $)$ & $\mathrm{MPa}$ \\
\hline $4 \mathrm{a}$ & 15 & 3,0 & 60 & 2231,92 & 93,86 & 95 \\
\hline $4 \mathrm{~b}$ & 15 & 3,0 & 45 & 3042,56 & 127,81 & 85 \\
\hline $5 \mathrm{a}$ & 15 & 4,5 & 60 & 2372,96 & 100,49 & 47 \\
\hline $5 \mathrm{~b}$ & 15 & 4,5 & 45 & 3204,08 & 135,60 & 43 \\
\hline $6 \mathrm{a}$ & 15 & 6,0 & 60 & 2563,80 & 109,14 & 26 \\
\hline $6 \mathrm{~b}$ & 15 & 6,0 & 45 & 3440,48 & 146,40 & 25 \\
\hline $7 \mathrm{a}$ & 30 & 3,0 & 60 & 1299,56 & 60,80 & 133 \\
\hline $7 \mathrm{~b}$ & 30 & 3,0 & 45 & 1776,20 & 83,06 & 117 \\
\hline $8 \mathrm{a}$ & 30 & 4,5 & 60 & 1399,80 & 65,94 & 68 \\
\hline $8 \mathrm{~b}$ & 30 & 4,5 & 45 & 1901,64 & 89,52 & 62 \\
\hline $9 \mathrm{a}$ & 30 & 6,0 & 60 & 1529,04 & 72,45 & 39 \\
\hline $9 \mathrm{~b}$ & 30 & 6,0 & 45 & 2063,76 & 97,76 & 37 \\
\hline
\end{tabular}

A partir dos dados da tabela 4.4 é possível obter as seguintes conclusões: 
$>$ A primeira e a mais óbvia conclusão é que ao diminuir a tensão admissível, há um acréscimo na área de aço necessária nos tirantes. Por exemplo, para $\mathrm{h}=\mathrm{L} / 33$ e $\mathrm{H}=\mathrm{L} / 10$ o aumento é de $35 \%$;

$>$ A flutuação de tensão nos tirantes é pouco influenciada pelo nível de tensão dos cabos, sendo que a máxima redução é de $12 \%$ para altura de torre igual a L/5 e altura de tabuleiro igual a L/50. O motivo desse comportamento é a maior rigidez do sistema de cabos devido à torre alta $\mathrm{e}$ à menor rigidez do tabuleiro, que é bastante flexível, tornando assim, o conjunto mais sensível ao aumento da área de aço;

$>$ Embora ao reduzir a tensão admissível, a flutuação de tensão não seja afetada significativamente, há uma melhoria do comportamento à fadiga dos cabos, pois é possível utilizar uma oscilação de tensão resistente maior;

$>$ Comparando o modelo $5 \mathrm{a}$ ao $7 \mathrm{~b}$, ou seja, a ponte com protensão no extradorso com uma ponte que, embora não seja uma ponte estaiada usual, tem tabuleiro flexível e torre alta, nota-se que o modelo $7 \mathrm{~b}$ necessita de menos área e peso de aço extradorsal.

\subsubsection{Influência sobre as solicitações normais e as flechas imediatas no tabuleiro}

Tabela 4.5 - Alguns esforços no tabuleiro ao variar o nível de tensão dos cabos.

\begin{tabular}{|c|c|c|c|c|c|c|c|}
\hline \multirow{3}{*}{ Modelo } & \multirow{2}{*}{$\mathrm{H}$} & \multirow{2}{*}{$\mathrm{h}$} & \multirow{2}{*}{$\sigma_{\mathrm{adm}}$} & \multirow{2}{*}{$\mathrm{N}_{\text {máx }}$} & Apoio int. & Vão central & \multirow{2}{*}{$a$} \\
\hline & & & & & $\mathrm{M}_{\text {mín }}$ & $\mathrm{M}_{\text {máx }}$ & \\
\hline & $\mathrm{m}$ & $\mathrm{m}$ & $\% f_{p t k}$ & $\mathrm{kN}$ & kN.m & kN.m & $\mathrm{cm}$ \\
\hline $4 a$ & 15 & 3,0 & 60 & 59976,4 & -133439 & 72937,0 & 40,0 \\
\hline $4 \mathrm{~b}$ & 15 & 3,0 & 45 & 61174,4 & -123667 & 67063,0 & 36,6 \\
\hline $5 a$ & 15 & 4,5 & 60 & 63978,2 & -171505 & 93543,8 & 20,4 \\
\hline $5 b$ & 15 & 4,5 & 45 & 64652,8 & -165671 & 90017,5 & 19,5 \\
\hline $6 a$ & 15 & 6,0 & 60 & 69030,8 & -196912 & 106189,0 & 11,8 \\
\hline $6 \mathrm{~b}$ & 15 & 6,0 & 45 & 69355,4 & -194032 & 104356,0 & 11,5 \\
\hline $7 \mathrm{a}$ & 30 & 3,0 & 60 & 30840,3 & -110256 & 55182,6 & 30,7 \\
\hline $7 b$ & 30 & 3,0 & 45 & 31516,2 & $-99303,8$ & 48058,2 & 26,7 \\
\hline $8 \mathrm{a}$ & 30 & 4,5 & 60 & 33291,2 & -151603 & 77971,4 & 17,1 \\
\hline $8 \mathrm{~b}$ & 30 & 4,5 & 45 & 33831,1 & -142614 & 71686,5 & 15,8 \\
\hline $9 a$ & 30 & 6,0 & 60 & 36281,8 & -181049 & 93298,8 & 10,4 \\
\hline $9 b$ & 30 & 6,0 & 45 & 36662,5 & -174720 & 88739,2 & 9,9 \\
\hline
\end{tabular}


A partir dos dados da tabela 4.5 é possível obter as seguintes conclusões:

> A redução da tensão admissível tem pouca influência sobre as solicitações normais e as flechas imediatas no tabuleiro. Por exemplo: para $\mathrm{H}=\mathrm{L} / 10 \mathrm{e}$ $\mathrm{h}=\mathrm{L} / 33$, o esforço normal aumenta $1,1 \%$, o momento mínimo no apoio diminui $3,4 \%$, o momento no vão central é reduzido em $3,8 \%$ e a flecha em $4,4 \%$

$>$ Assim como ocorre com a flutuação de tensão, os modelos que sofrem maior influência ao variar o nível de tensão dos cabos são aqueles que possuem tabuleiros flexíveis (principalmente os que também possuem torres altas).

A figura 4.16 mostra os diagramas de momentos permanentes e as envoltórias de momento dos modelos $5 \mathrm{a}$ e $5 \mathrm{~b}(\mathrm{H}=\mathrm{L} / 10 \mathrm{e} \mathrm{h}=\mathrm{L} / 33)$.

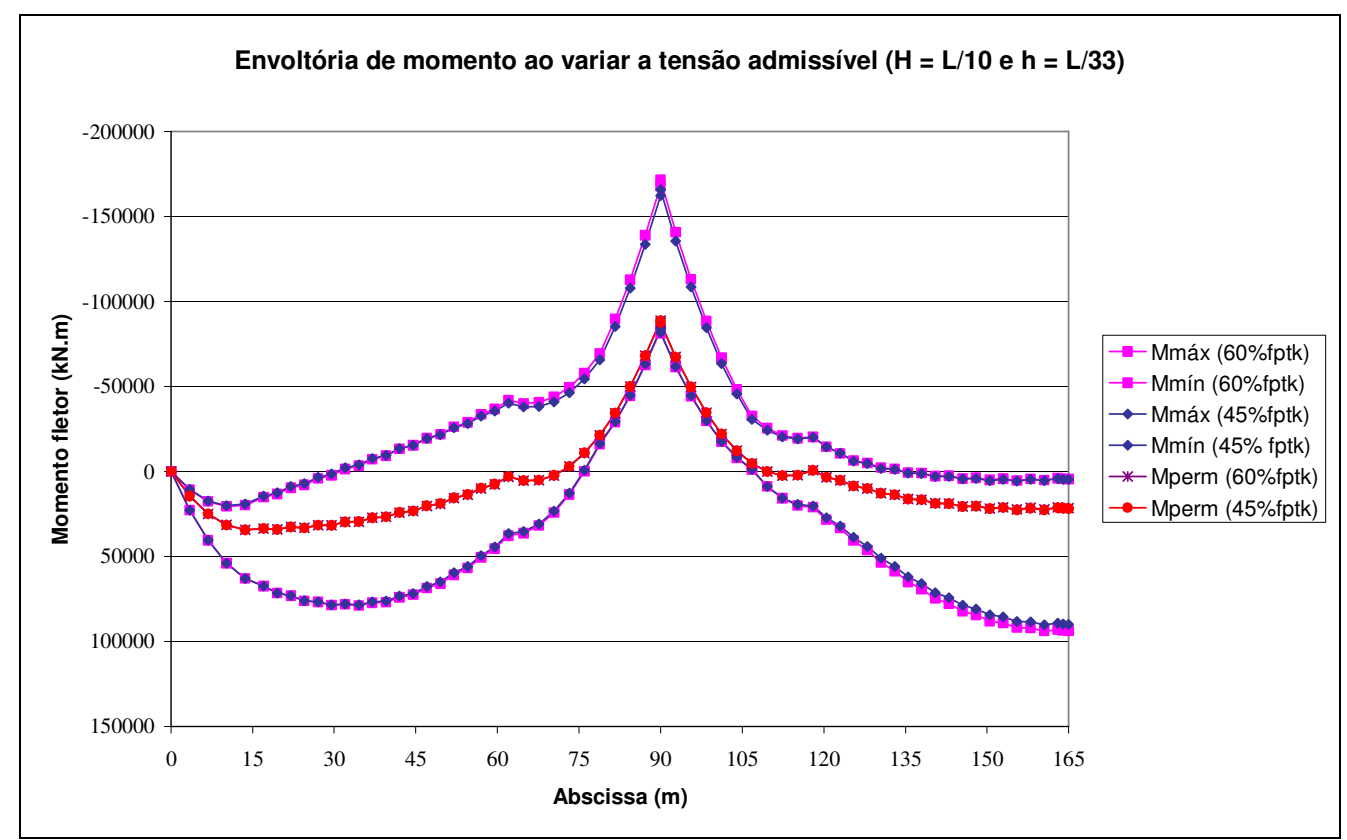

Figura 4.16 - Envoltória de momentos fletores ao variar a tensão admissível dos cabos, considerando a altura da torre igual a $15 \mathrm{~m}(\mathrm{~L} / 10)$ e a do tabuleiro igual a 4,5 $\mathrm{m}(\mathrm{L} / 33)$. 


\subsection{COMPORTAMENTO ESTRUTURAL AO MODIFICAR O NÍVEL DE COMPENSAÇÃO DE CARGAS PERMANENTES}

Neste item será realizada uma comparação entre os modelos 5a e 5c. A única diferença entre eles é que no modelo 5 c a protensão de cada cabo é igual a $80 \%$ daquela obtida no modelo 5a, ou seja, $P_{i}=0,8 R_{i} / \operatorname{sen} \alpha$.

De acordo com a tabela 4.6, ao reduzir o nível de compensação de cargas, há um redução de $15 \%$ na área de aço necessária e um pequeno aumento na flutuação de tensão máxima nos tirantes que é igual a $4 \%$.

Tabela 4.6 - Área de aço extradorsal e flutuação de tensão máxima ao variar o nível de compensação de cargas.

\begin{tabular}{|c|c|c|c|c|c|}
\hline \multirow{2}{*}{ Modelo } & $\mathrm{H}$ & $\mathrm{H}$ & \multirow{2}{*}{$\begin{array}{l}\text { Nivel de } \\
\text { comp. }\end{array}$} & $\mathrm{A}_{\mathrm{p}, \text { total }}$ & $\Delta \sigma_{\mathrm{p}, \text { máx }}$ \\
\hline & (m) & (m) & & $\left(\mathrm{cm}^{2}\right)$ & $\mathrm{MPa}$ \\
\hline $5 a$ & 15 & 4,5 & $100 \%$ & 2372,96 & 47 \\
\hline $5 c$ & 15 & 4,5 & $80 \%$ & 2023,56 & 49 \\
\hline
\end{tabular}

Pelo critério de fadiga adotado, ao considerar o nível de compensação de cargas permanente igual a $80 \%$, mantendo a torre em $\mathrm{L} / 10$, o limite para a altura do tabuleiro aumenta um pouco em relação à $100 \%$ de compensação, passando de L/34 para $\mathrm{L} / 33$.

A redução da área de aço ao diminuir a protensão extradorsal em $20 \%$, se deve ao fato de que a tensão no aço devido às cargas permanente é praticamente a mesma (já que a variação da tensão frente às cargas variáveis não altera significativamente).

Quanto aos esforços no tabuleiro (tabela 4.7), ao diminuir a protensão dos cabos, os momentos máximos, em módulo, no tabuleiro aumentam (47\% no vão lateral, $48 \%$ no apoio e $72 \%$ no meio do vão central) e o esforço normal máximo diminui (15\% no apoio).

Isso ocorre, pois, quanto menor for a protensão, maior é a deformação da estrutura devido ao carregamento permanente e, consequentemente, maiores são os momentos fletores. O esforço normal é reduzido, pois a componente horizontal da 
protensão também diminui. Obviamente, a redução da área também afeta esses parâmetros, mas de acordo com o item 4.4, a sua influência é pequena.

Tabela 4.7 - Alguns esforços no tabuleiro ao variar o nível de compensação de cargas permanentes.

\begin{tabular}{|c|c|c|c|c|c|c|c|c|}
\hline \multirow{3}{*}{ Modelo } & \multirow{2}{*}{$\mathrm{H}$} & \multirow[t]{2}{*}{$\mathrm{h}$} & \multirow{3}{*}{$\begin{array}{c}\text { Nível de } \\
\text { comp. }\end{array}$} & \multirow{2}{*}{$\mathrm{N}_{\text {máx }}$} & Vão lateral & Apoio int. & Vão central & \multirow{2}{*}{$a$} \\
\hline & & & & & $\mathbf{M}_{\text {máx }}$ & $\mathbf{M}_{\text {mín }}$ & $\mathrm{M}_{\text {máx }}$ & \\
\hline & $\mathrm{m}$ & $\mathrm{m}$ & & $\mathrm{kN}$ & kN.m & kN.m & kN.m & $\mathrm{cm}$ \\
\hline $5 a$ & 15 & 4,5 & $100 \%$ & 63978,2 & 63978,2 & -171505 & 935 & 20,4 \\
\hline $5 c$ & 15 & 4,5 & $80 \%$ & 54455,4 & 94157,7 & -253434 & 161333,0 & 33,5 \\
\hline
\end{tabular}

As figuras 4.17, 4.18 e 4.19 apresentam os momentos permanentes, os momentos máximos e mínimos para as cargas variáveis e as envoltórias de momento, respectivamente.

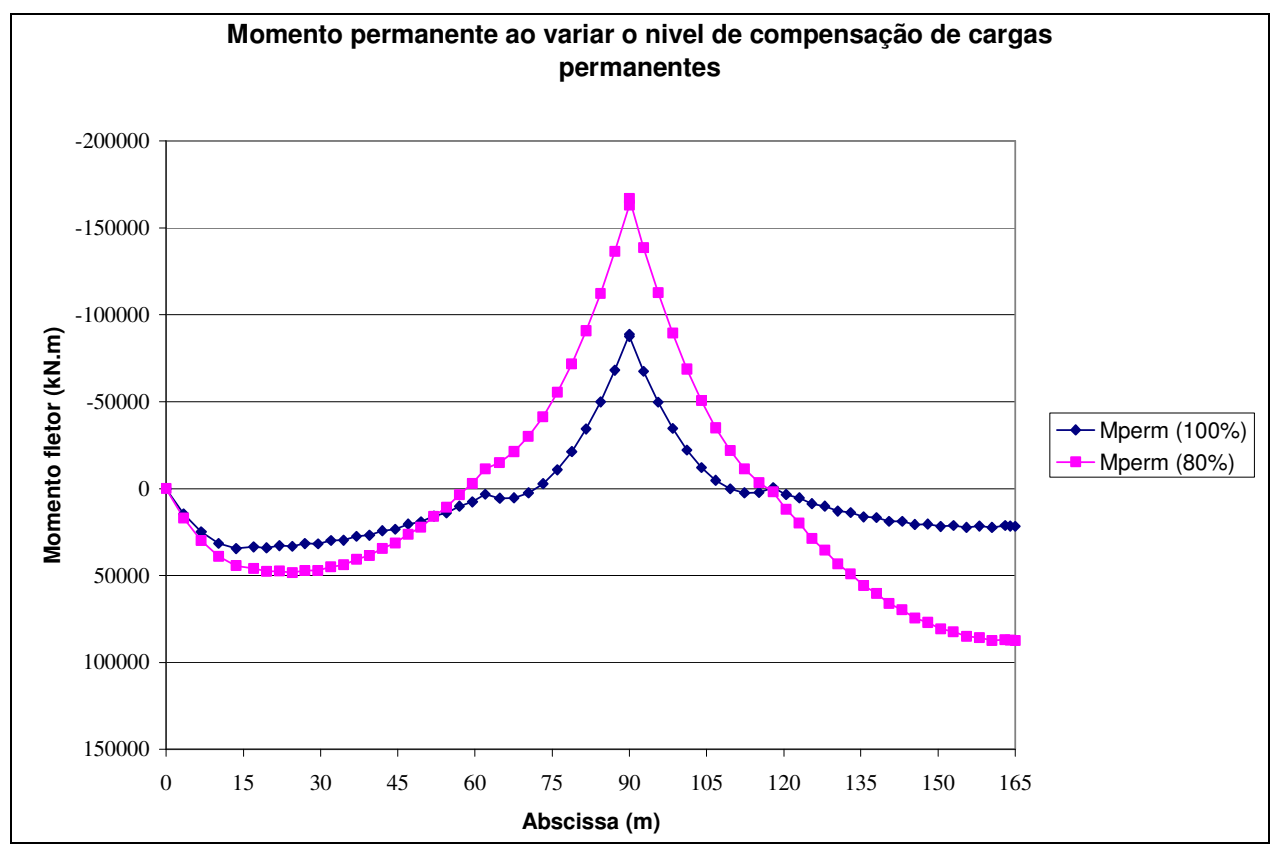

Figura 4.17 - Momento fletor permanente ao variar o nível de compensação de cargas permanentes, considerando $\mathrm{H}=15 \mathrm{~m}(\mathrm{~L} / 10)$ e $\mathrm{h}=4,5 \mathrm{~m}(\mathrm{~L} / 33)$. 


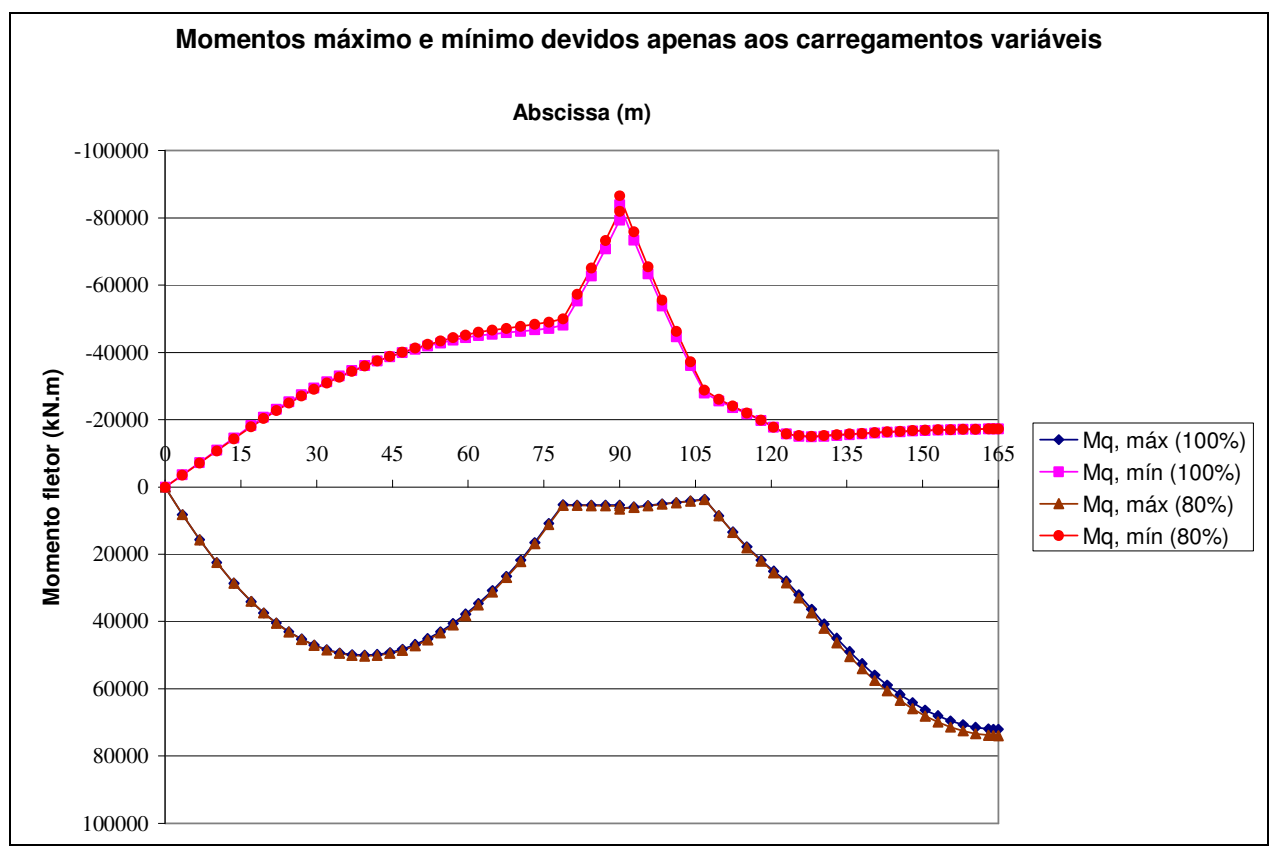

Figura 4.18 - Momentos máximos e mínimos devidos apenas aos carregamentos variáveis ao modificar o nível de compensação de cargas, considerando a altura da torre igual a $15 \mathrm{~m}(\mathrm{~L} / 10)$ e a altura do tabuleiro igual a $4,5 \mathrm{~m}(\mathrm{~L} / 33)$.

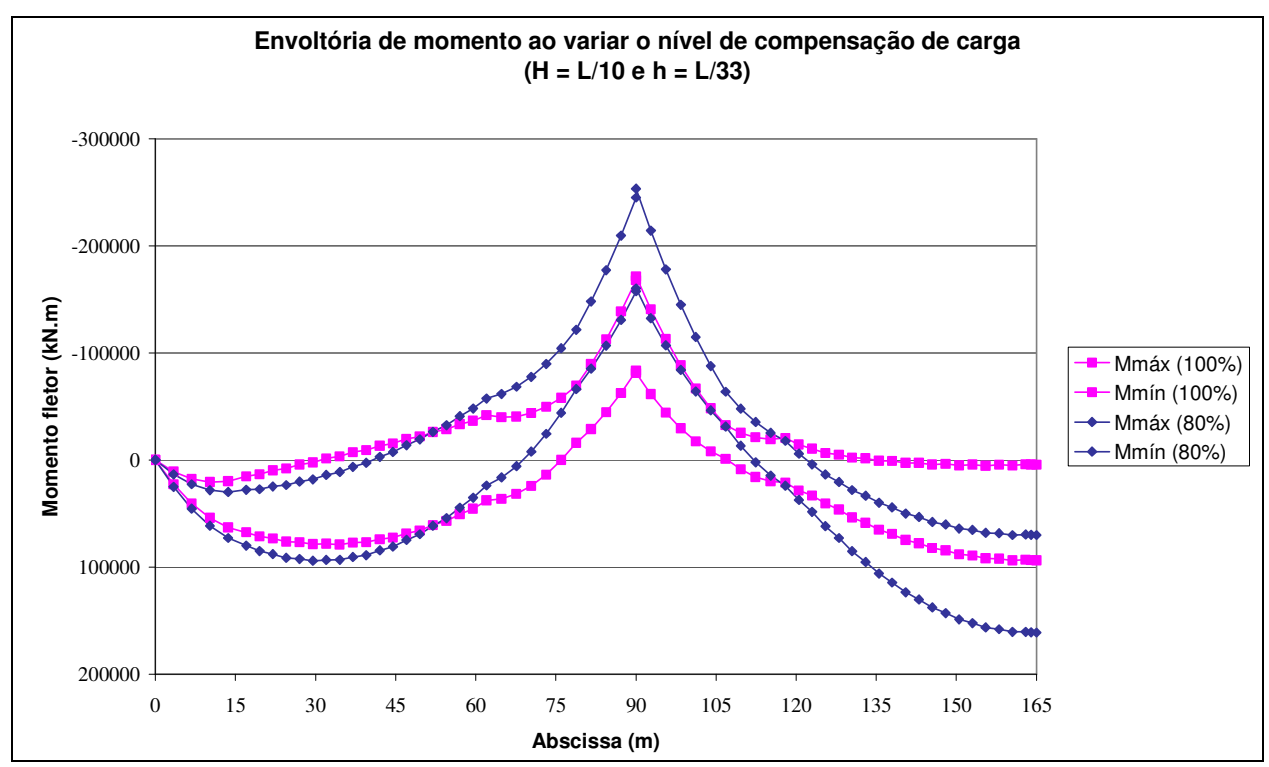

Figura 4.19 - Envoltórias de momento fletor ao variar o nível de compensação de cargas permanentes, considerando $\mathrm{H}=15 \mathrm{~m}(\mathrm{~L} / 10)$ e $\mathrm{h}=4,5 \mathrm{~m}(\mathrm{~L} / 33)$.

De acordo com a figura 4.18, percebe-se que as envoltórias de momentos devido às cargas variáveis dos modelos 5a e 5c são muito próximas, indicando que o comportamento estrutural frente a tais cargas pouco se altera. 


\subsection{ANÁlise dA PROPORÇÃo ENTRE O VÃO LATERAL E O VÃO CENTRAL}

Neste item serão comparados os modelos: 5a, 5d, 5e, 5f e 5g.

\subsubsection{Influência sobre a área de aço extradorsal e variação da flutuação de tensão nos cabos}

Tabela 4.8 - Área de aço extradorsal e flutuação de tensão máxima ao variar o comprimento do vão lateral.

\begin{tabular}{|c|c|c|c|c|c|c|}
\hline \multirow{2}{*}{ Modelo } & $\mathrm{H}$ & $\mathrm{h}$ & \multicolumn{2}{|c|}{$\mathrm{L}_{1}$} & $\mathrm{~A}_{\mathrm{p}, \text { total }}$ & $\Delta \sigma_{\mathrm{p}, \text { máx }}$ \\
\cline { 2 - 7 } & $(\mathrm{m})$ & $(\mathrm{m})$ & $\% \mathrm{~L}$ & $(\mathrm{~m})$ & $\left(\mathrm{cm}^{2}\right)$ & $\mathrm{MPa}$ \\
\hline $5 \mathrm{~d}$ & 15 & 4,5 & 48 & 72,0 & 2373,48 & 41,9 \\
\hline $5 \mathrm{e}$ & 15 & 4,5 & 50 & 75,0 & 2373,48 & 42,7 \\
\hline $5 \mathrm{f}$ & 15 & 4,5 & 55 & 82,5 & 2374,32 & 45,0 \\
\hline $5 \mathrm{a}$ & 15 & 4,5 & 60 & 90,0 & 2372,96 & 46,7 \\
\hline $5 \mathrm{~g}$ & 15 & 4,5 & 65 & 97,5 & 2377,04 & 47,7 \\
\hline \multicolumn{7}{|l|}{$\mathrm{L}_{1}-$ Vão lateral } \\
\hline
\end{tabular}

A partir dos dados da tabela 4.8 podemos retirar as seguintes conclusões:

A área de aço extradorsal praticamente não se altera. No entanto, percebese um ligeiro aumento de $0,15 \%$ ao variar $\mathrm{L}_{1}$ de $50 \% \mathrm{~L}$ a $65 \%$. Esse resultado é razoável, uma vez que ao aumentar o vão lateral, aumenta-se também as cargas a serem levantadas pelos cabos e transmitidas às fundações. Nota-se, também, que as áreas nos modelos $5 \mathrm{~d}$ e 5 e são as mesmas, embora se pudesse esperar que fosse um pouco menor em $5 \mathrm{e}$, contudo, o fato do modelo $5 \mathrm{~d}$ possuir cabos ancorados sobre os apoios extremos faz com que a redução das cargas seja compensada pelo aumento da rigidez do sistema de tirantes;

$>\mathrm{O}$ valor da área de aço no modelo $5 \mathrm{a}\left(\mathrm{L}_{1}=60 \% \mathrm{~L}\right)$ é o menor entre todos os analisados neste item. Percebe-se que esse valor não mantém a tendência que se mostra para os modelos $5 \mathrm{e}, 5 \mathrm{f}$ e $5 \mathrm{~g}$. Uma explicação para tanto é que nem todos os cabos possuem tensão máxima igual a 1140 $\operatorname{MPa}\left(60 \% f_{p t k}\right)$; 
Ao aumentar o comprimento do vão lateral, há um acréscimo na flutuação de tensão máxima (figura 4.20), no entanto essa variação é pequena, por exemplo: ao mudar o vão lateral de $0,48 \mathrm{~L}$ para $0,65 \mathrm{~L}$ o aumento em $\Delta \sigma_{\text {máx }}$ é de apenas $14 \%$;

Apesar do modelo 5d possuir cabos de ancoragem, a flutuação de tensão máxima nos cabos é a menor de todos os casos analisados. Isso ilustra, nitidamente, que esses cabos não têm a mesma função que os estais de ancoragem das pontes estaiadas, pois embora a rigidez do sistema de cabos se eleve, a rigidez do tabuleiro continua desenvolvendo um papel importante no transporte das cargas aos apoios.

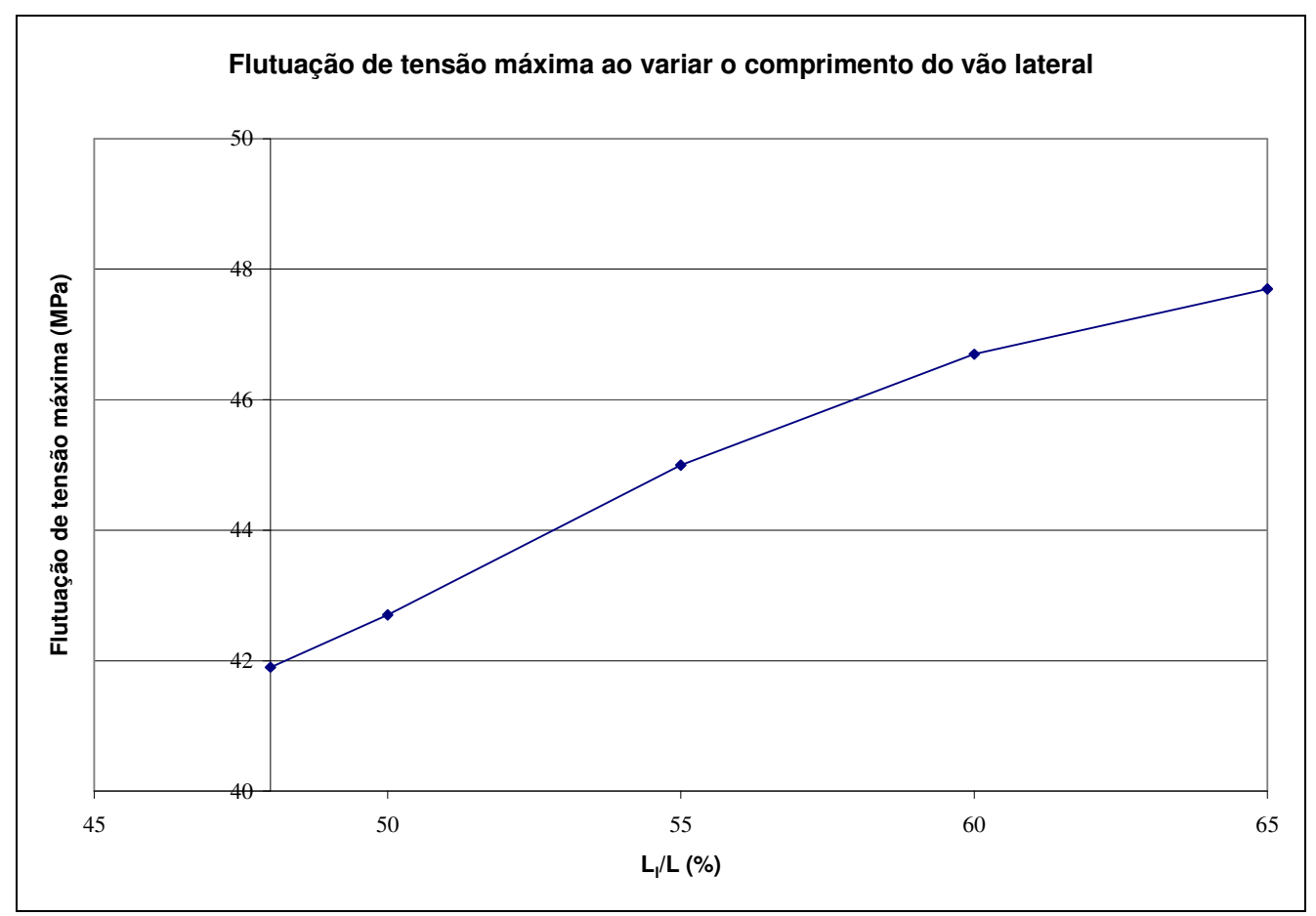

Figura 4.20 - Flutuação de tensão máxima dos cabos no extradorso ao variar o comprimento do vão lateral, considerando a altura da torre igual a $15 \mathrm{~m}(\mathrm{~L} / 10)$ e a altura do tabuleiro igual a $4,5 \mathrm{~m}(\mathrm{~L} / 33)$; 


\subsubsection{Influência sobre os diagramas de momento fletor, de esforço normal e sobre as flechas imediatas.}

Tabela 4.9 - Alguns esforços no tabuleiro ao variar o comprimento do vão lateral.

\begin{tabular}{|c|c|c|c|c|c|c|c|c|}
\hline \multirow{3}{*}{ Modelo } & $\mathrm{H}$ & $\mathrm{h}$ & $\mathrm{L}_{1}$ & $\mathrm{R}_{\text {mín, apoio }}$ & Vão lateral & Apoio int. & Vão cent. & \multirow{2}{*}{$a$} \\
\hline & П & 11 & $L_{1}$ & extremo & $\mathbf{M}_{\text {máx }}$ & $\mathrm{M}_{\text {mín }}$ & $\mathrm{M}_{\text {máx }}$ & \\
\hline & $\mathrm{m}$ & $\mathrm{m}$ & $\% \mathrm{~L}$ & $\mathrm{kN}$ & kN.m & kN.m & kN.m & $\mathrm{cm}$ \\
\hline $5 d$ & 15 & 4,5 & 48 & $-1678,28$ & 37760,2 & -163809 & 94515,4 & 20,7 \\
\hline $5 e$ & 15 & 4,5 & 50 & $-981,6$ & 39984,9 & -164205 & 95161,3 & 20,8 \\
\hline $5 f$ & 15 & 4,5 & 55 & 1451,7 & 54409,1 & -166820 & 96006,6 & 21,1 \\
\hline $5 a$ & 15 & 4,5 & 60 & 3648,6 & 78978,4 & -171505 & 93543,8 & 20,4 \\
\hline $5 \mathrm{~g}$ & 15 & 4,5 & 65 & 5656,6 & 115404,0 & -179012 & 87654,3 & 18,6 \\
\hline
\end{tabular}

A partir dos dados da tabela 4.9 podemos extrair as seguintes conclusões:

Tanto o momento máximo no meio do vão central, quanto a flecha aumentam ao variar $\mathrm{L}_{1}$ de $48 \% \mathrm{~L}$ para $55 \% \mathrm{~L}$ e a partir deste último até $65 \% \mathrm{~L}$ seus valores diminuem (figuras 4.21 e 4.20 ). O comportamento do segundo trecho é similar ao variar o comprimento do vão lateral em uma viga de três vãos. Já a tendência do primeiro trecho se deve à proximidade dos cabos em relação ao apoio extremo, pois quanto mais próximo for, maior é a rigidez do sistema de cabos, reduzindo assim, o momento fletor e as flechas no meio do vão central do tabuleiro;

$>$ Quanto maior for o comprimento do vão lateral, maior é o momento máximo no mesmo e menor o momento mínimo no apoio intermediário, sendo que sua influência sobre este último é bem pequena, por exemplo: ao passar $\mathrm{L}_{1}$ de $48 \% \mathrm{~L}$ para $65 \% \mathrm{~L}$, o decréscimo é de $9 \%$;

> Com relação à reação mínima nos apoios, quanto menor for o vão lateral, menor é o seu valor (figura 4.23), sendo que para proporções entre vãos menores ou iguais a, aproximadamente, 52\%, esta reação é negativa, resultando na necessidade de medidas adicionais para evitar o levantamento do tabuleiro. 


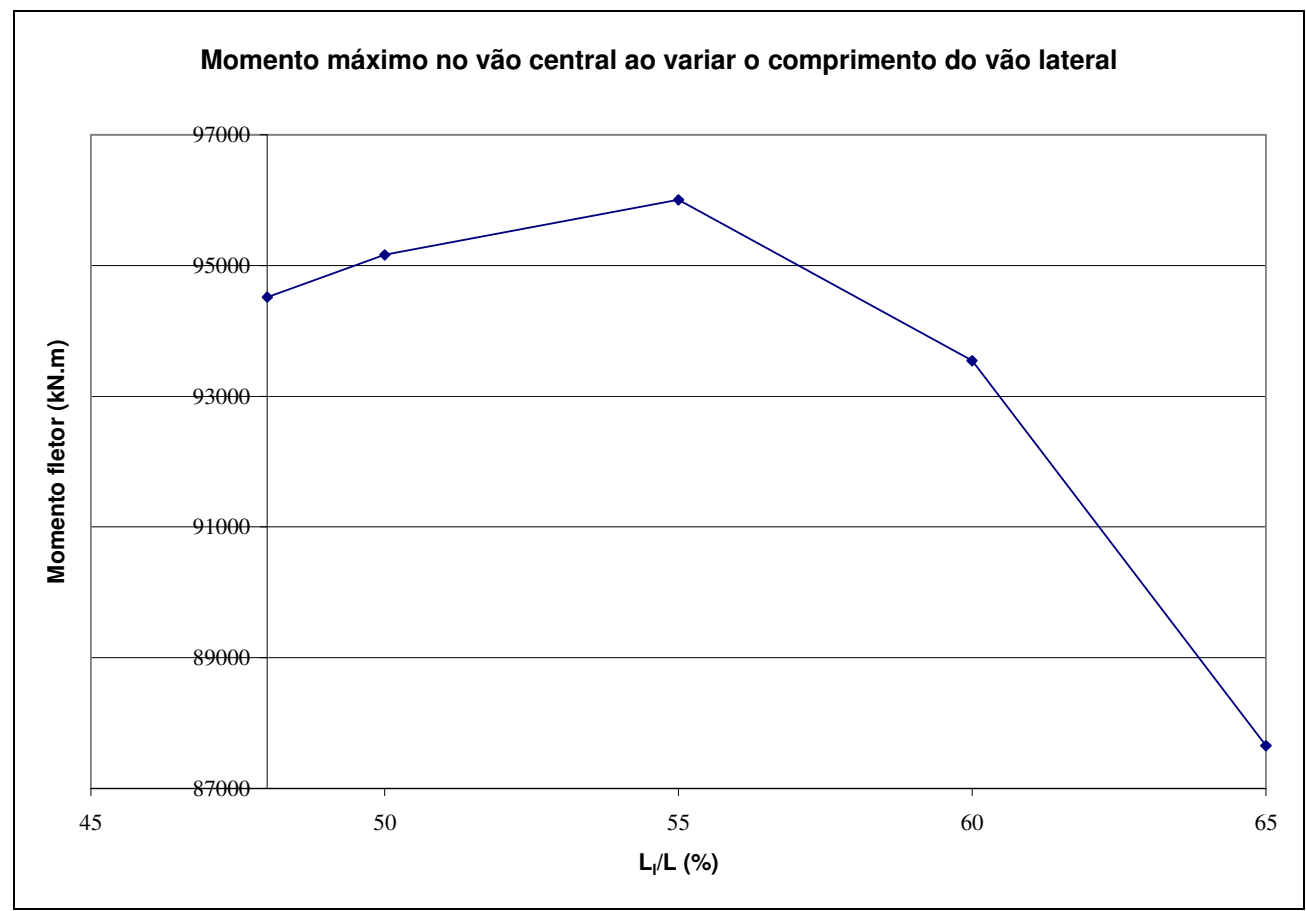

Figura 4.21 - Momento máximo no meio do vão central ao variar o comprimento do vão lateral $(\mathrm{H}=\mathrm{L} / 10 \mathrm{e} \mathrm{h}=\mathrm{L} / 33)$.

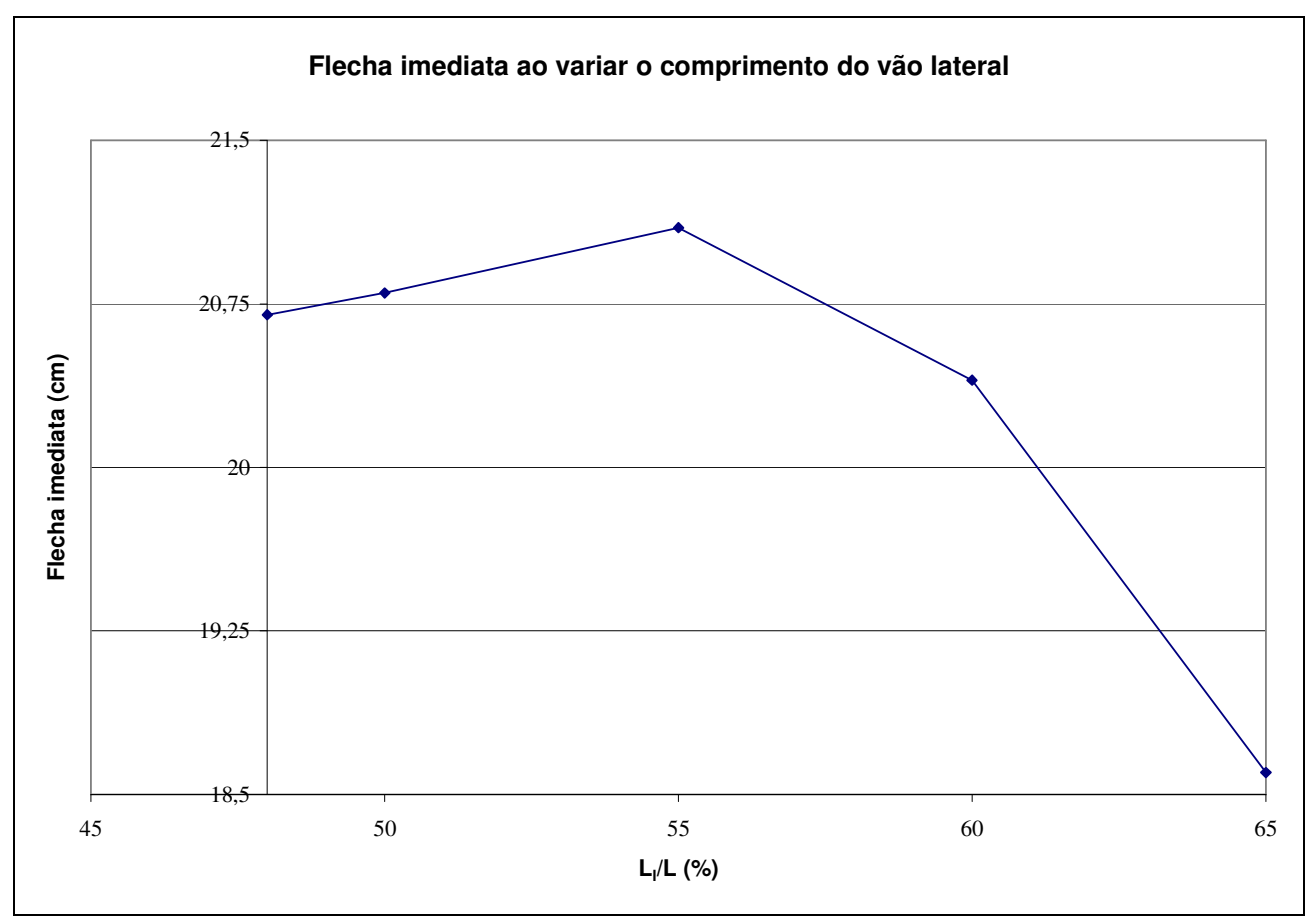

Figura 4.22 - Flecha imediata no tabuleiro central ao variar o comprimento do vão lateral $(\mathrm{H}=\mathrm{L} / 10$ e $\mathrm{h}=\mathrm{L} / 33)$. 


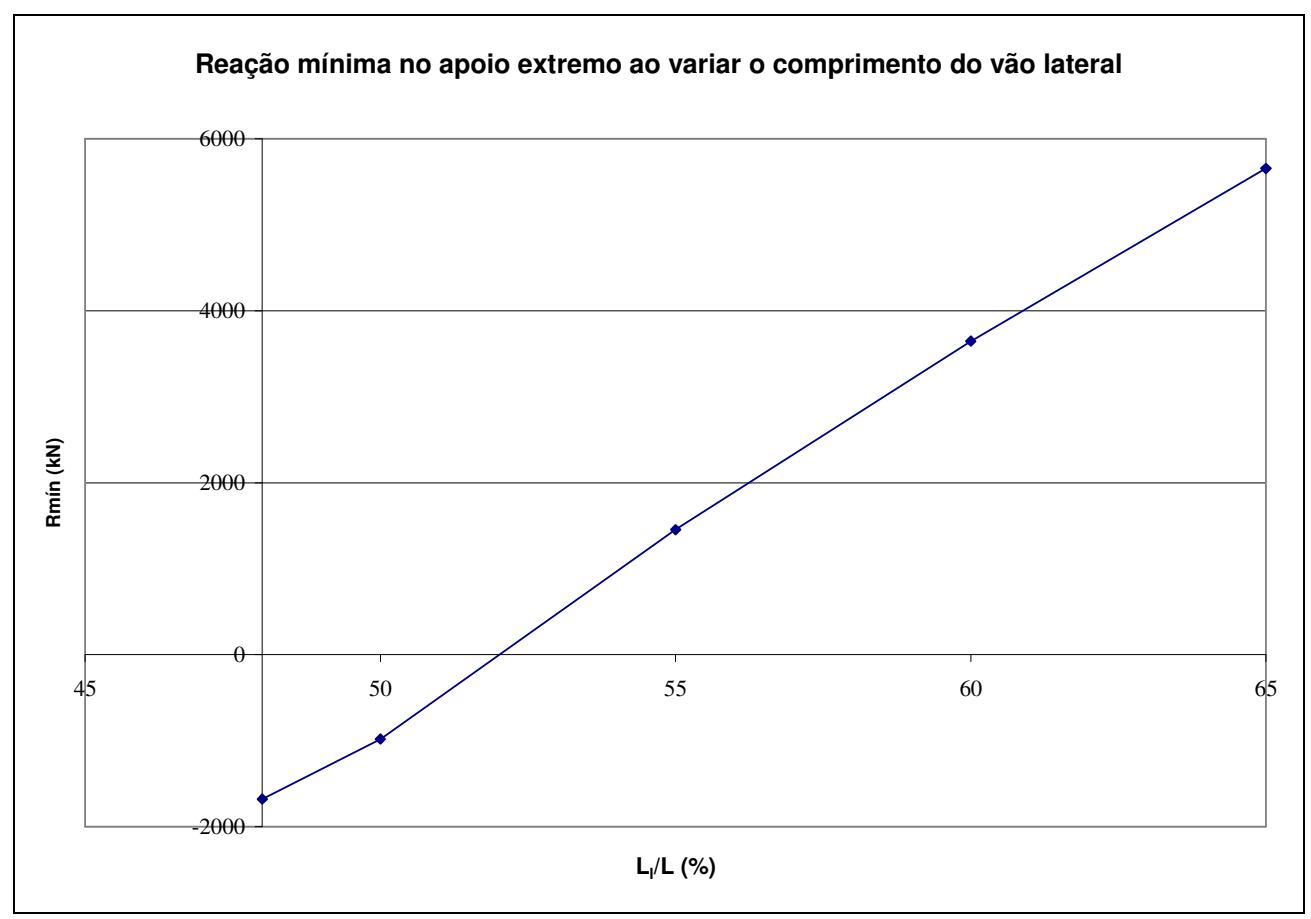

Figura 4.23 - Reação mínima nos apoios extremos ao variar o comprimento do vão lateral $(\mathrm{H}=\mathrm{L} / 10$ e $\mathrm{h}=\mathrm{L} / 33)$.

A figura 4.24 mostra os diagramas de momento fletor devido ao carregamento permanente ao variar o comprimento do vão lateral.

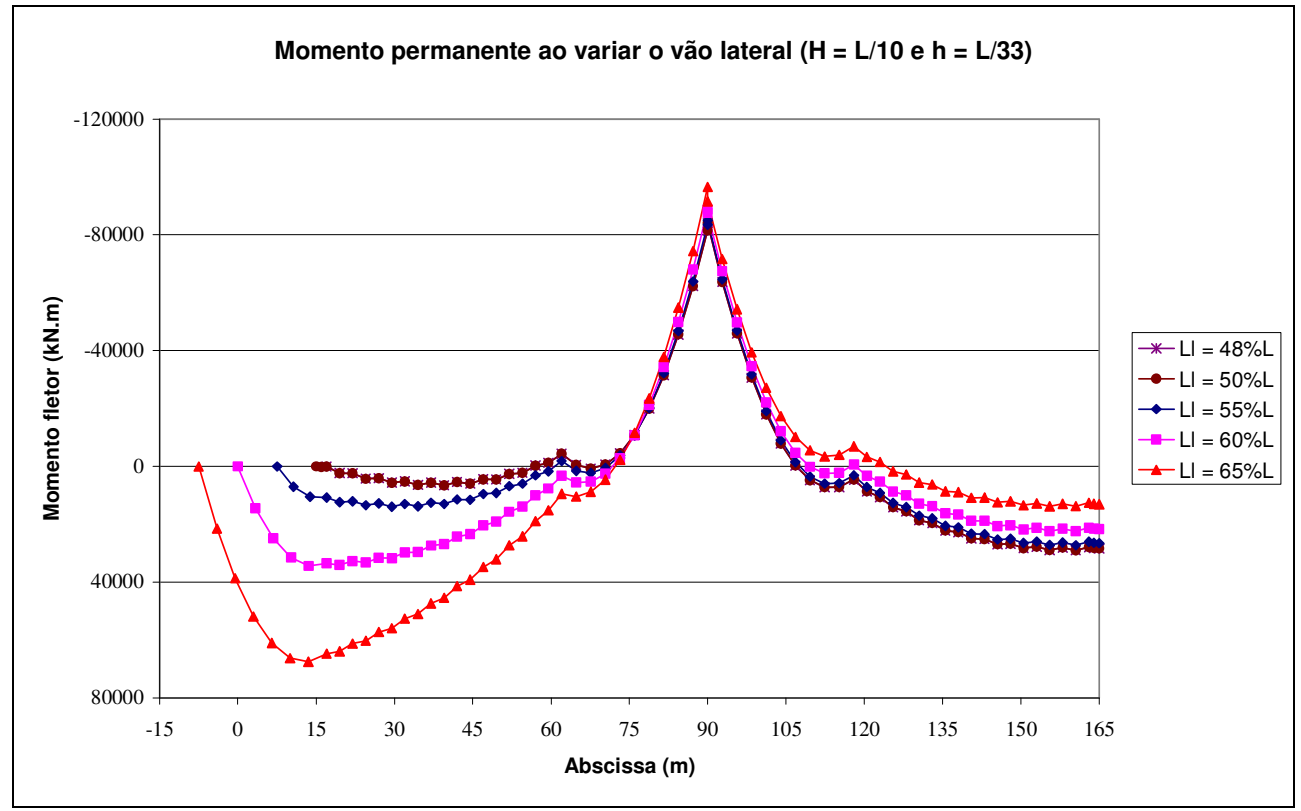

Figura 4.24 - Momento fletor devido ao carregamento permanente ao variar o comprimento do vão lateral, considerando $\mathrm{H}=15 \mathrm{~m}(\mathrm{~L} / 10) \mathrm{e} \mathrm{h}=4,5 \mathrm{~m}(\mathrm{~L} / 33)$. 
Em respeito à escolha da proporção entre os vãos, um critério bastante empregado para vigas contínuas é ter os momentos fletores nos vãos lateral e central aproximadamente iguais, pois assim (no caso de tabuleiro constante) temos a mesma seção em ambos os vãos resistindo ao mesmo esforço, evitando assim uma subutilização da capacidade resistente da seção em um dos vãos.

No caso das pontes com protensão no extradorso, o tabuleiro está sujeito a esforços normais devido à inclinação dos cabos, com isso o critério descrito pode não ser mais satisfatório, sendo necessário estudar para cada situação a melhor solução.

Para os parâmetros e condições de contorno adotados e analisando a envoltória de momento fletor ao variar o comprimento do vão lateral (figura 4.25), pode-se adotar o mesmo critério das vigas contínuas ou arbitrar o momento máximo no vão lateral um pouco maior que o do vão central, uma vez que existe um esforço normal de compressão devido a alguns cabos no extradorso na região de momento máximo no vão lateral. Logo, uma boa proporção entre os vãos está entre $60 \% \mathrm{~L}$ e $65 \% \mathrm{~L}$.

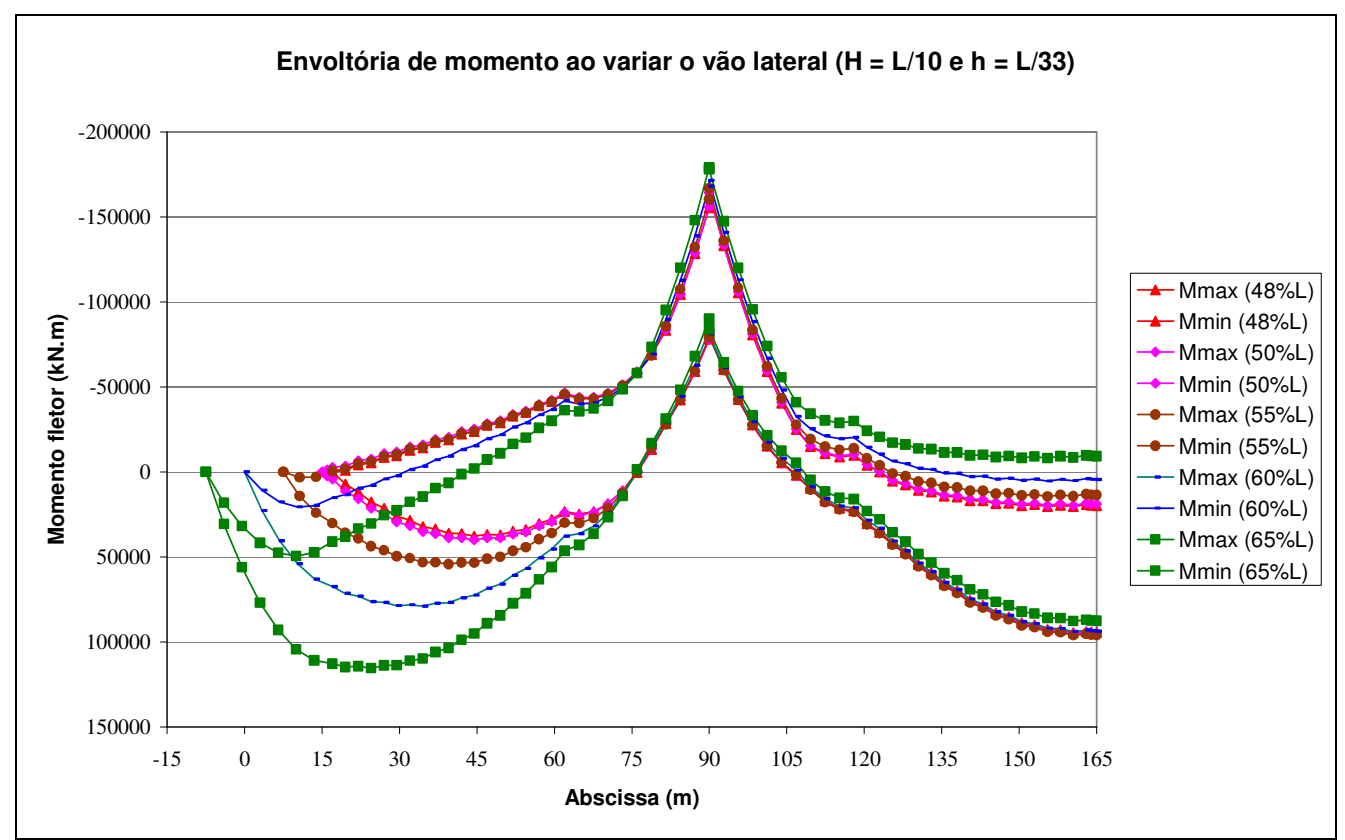

Figura 4.25 - Envoltória de momento fletor ao variar o comprimento do vão lateral, considerando $\mathrm{H}=15 \mathrm{~m}(\mathrm{~L} / 10)$ e $\mathrm{h}=4,5 \mathrm{~m}(\mathrm{~L} / 33)$. 


\subsection{RESULTADO DO PROCESSAMENTO DO MODELO 10 (h VARIÁVEL)}

Neste item foram analisadas as recomendações de CHO (2000) para as dimensões a serem adotadas em pontes com protensão no extradorso que possuem altura de tabuleiro variável.

O processamento do trecho de $27 \mathrm{~m}$ de altura variável foi realizado através de 9 segmentos de altura constante (figura 4.26).
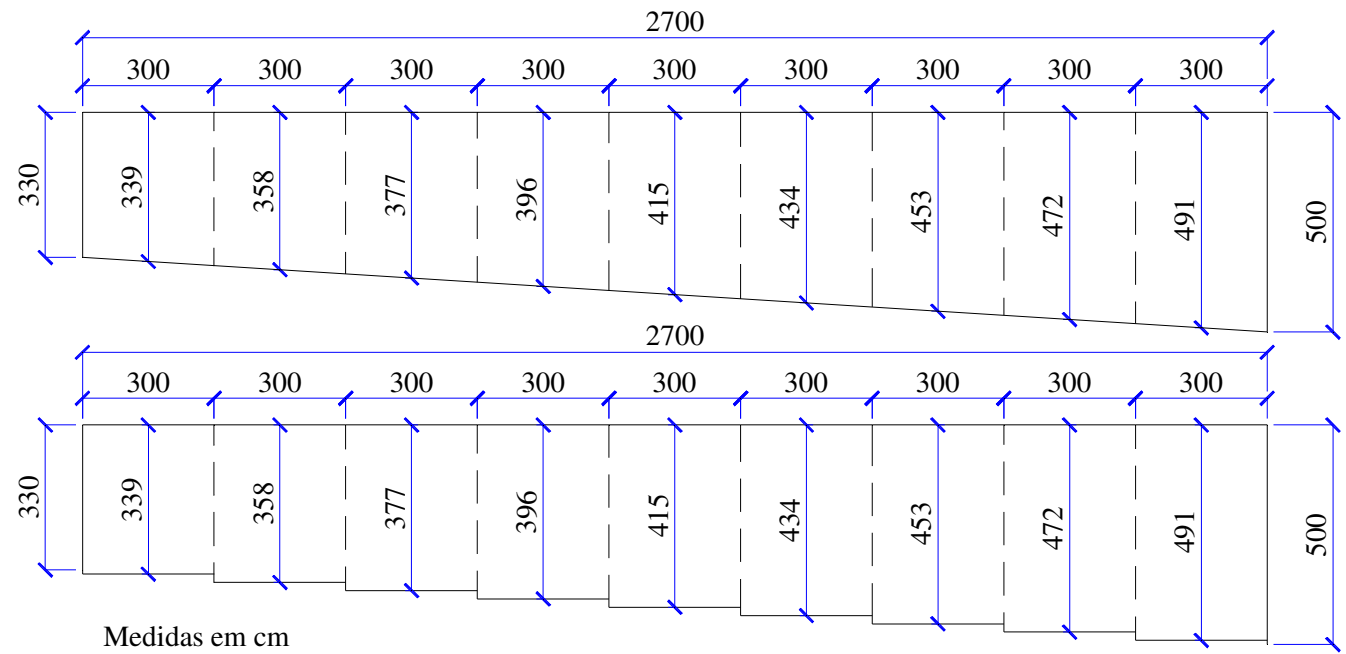

Figura 4.26 - Idealização do trecho do tabuleiro com altura variável.

Na tabela 4.10, temos a protensão média, a tensão máxima e mínima, a área de aço e a flutuação de tensão de cada cabo no extradorso do modelo 10.

Tabela 4.10 - Protensão, tensão máxima e mínima, área de aço e flutuação de tensão dos cabos no extradorso do modelo 10.

\begin{tabular}{|c|c|c|c|c|c|c|}
\hline \multirow{2}{*}{\multicolumn{2}{|c|}{ Cabo }} & $\mathrm{P}$ & Ap & $\sigma_{\text {máx }}$ & $\sigma_{\operatorname{mín}}$ & $\Delta \sigma$ \\
\hline & & $(\mathrm{kN})$ & $\left(\mathrm{cm}^{2}\right)$ & (MPa) & (MPa) & (MPa) \\
\hline 1 & 4 & \multirow{2}{*}{12143,44} & \multirow{2}{*}{116,76} & 1136 & 1051 & 43 \\
\hline 2 & 3 & & & 1139 & 1047 & 46 \\
\hline 5 & 8 & \multirow{2}{*}{4515,83} & \multirow{2}{*}{43,17} & 1138 & 1051 & 44 \\
\hline 6 & 7 & & & 1139 & 1049 & 45 \\
\hline 9 & 12 & \multirow{2}{*}{5027,75} & \multirow{2}{*}{47,75} & 1141 & 1053 & 44 \\
\hline 10 & 11 & & & 1140 & 1054 & 43 \\
\hline 13 & 16 & \multirow{2}{*}{5479,50} & \multirow{2}{*}{51,99} & 1142 & 1046 & 48 \\
\hline 14 & 15 & & & 1134 & 1054 & 40 \\
\hline 17 & 20 & \multirow{2}{*}{5891,73} & \multirow{2}{*}{56,06} & 1141 & 1029 & 56 \\
\hline 18 & 19 & & & 1122 & 1048 & 37 \\
\hline
\end{tabular}




\begin{tabular}{|c|c|c|c|c|c|c|}
\hline 21 & 24 & \multirow{2}{*}{6274,82} & \multirow{2}{*}{59,87} & 1139 & 1012 & 64 \\
\hline 22 & 23 & & & 1110 & 1042 & 34 \\
\hline 25 & 28 & \multirow{2}{*}{6634,25} & \multirow{2}{*}{63,42} & 1139 & 998 & 71 \\
\hline 26 & 27 & & & 1099 & 1039 & 30 \\
\hline 29 & 32 & \multirow{2}{*}{6972,70} & \multirow{2}{*}{66,66} & 1140 & 986 & 77 \\
\hline 30 & 31 & & & 1097 & 1032 & 33 \\
\hline \multicolumn{7}{|c|}{$\begin{array}{l}\sigma_{\text {máx }} \sigma_{\text {mín }}-\text { Tensão máxima e mínima, respectivamente, } \\
\text { considerando a combinação rara das ações. } \\
\Delta \sigma_{\mathrm{p}}-\text { Flutuação de tensão nos cabos considerando a } \\
\text { combinação freqüente das ações }\left(\psi_{1}=0,5\right) \text {. }\end{array}$} \\
\hline
\end{tabular}

A partir dos dados da tabela 4.10, nota-se que a flutuação de tensão máxima dos cabos no extradorso é igual a $77 \mathrm{MPa}$, o que ultrapassa o limite estabelecido no capítulo 2 que é de $50 \mathrm{MPa}$. Logo, as recomendações de CHO (2000) não são adequadas à definição de ponte com protensão no extradorso deste trabalho.

Não faz parte do escopo desta dissertação a análise paramétrica de pontes com altura de tabuleiro variável, de forma a buscar recomendações de prédimensionamento, mas pode ser visto no anexo III algumas tentativas sem sucesso de obter um modelo que se enquadra na definição de protensão extradorsal e tivesse benefícios em relação às pontes com altura de tabuleiro constante. De qualquer forma, os resultados apresentados no anexo III permitem analisar o efeito de alguns parâmetros na flutuação de tensão dos cabos.

\subsection{COMPORTAMENTO ESTRUTURAL FRENTE À PROTENSÃO INTERNA OU EXTERNA CONVENCIONAL}

Neste item será analisada a necessidade do uso de protensão interna ou externa convencional ao longo do tabuleiro para os modelos 5a (básico) e 5c, além de estudar a sua influência nos esforços e deslocamentos da estrutura.

$\mathrm{Na}$ análise foi adotada a protensão limitada, ou seja, é preciso respeitar, para a combinação freqüente das ações, o estado limite de formação de fissura ${ }^{\text {VII }}$ (ELS F) e para a combinação quase permanente das ações, o estado limite de descompressão $^{\text {VIII }}$ (ELS - D).

\footnotetext{
VII A definição do estado limite de formação de fissura já foi descrita no capítulo 2, pg. 9.

VIII A definição do estado limite de descompressão já foi descrita no capítulo 2, pg. 9.
} 
Os coeficientes de redução adotados $\left(\psi_{1}=0,5\right.$ e $\left.\psi_{2}=0,3\right)$ correspondem àqueles das pontes rodoviárias (NBR8681, 2003).

A protensão interna se faz necessária nos locais onde as tensões geradas pelas ações externas não obedecem aos estados limites estabelecidos. Com isso, é preciso fazer um estudo das tensões máximas e mínimas nas fibras superiores e inferiores ao longo do tabuleiro com o intuito de investigar onde se faz necessária tal protensão.

A obtenção das envoltórias de tensão nas fibras extremas para os 15 casos de carregamento variável é um tanto trabalhoso, uma vez que temos que determinar os 15 pares $\mathrm{M}_{\mathrm{q}}$ e $\mathrm{N}_{\mathrm{q}}$ (concomitantes). Com intuito de simplificar os cálculos das tensões, será admitido que somente o carregamento permanente provoque esforço normal, ou seja, $\mathrm{N}_{\mathrm{q}}$ sempre igual a zero. Essa aproximação é bastante satisfatória, uma vez que o tal esforço, devido a cargas variáveis, é pequeno.

A convenção dos sinais que indica se a tensão é de tração ou compressão é a mesma para o esforço normal, ou seja, positivo para compressão e negativo para tração.

Para o estado limite de formação de fissura, o limite da tensão de tração é dado pela expressão (NBR6118, 2003):

$$
f_{c t, f}=\alpha \cdot f_{c t k, \mathrm{inf}}
$$

onde:

$f_{c t, f} \quad$ é a resistência do concreto à tração na flexão;

$\alpha \quad$ é o fator que correlaciona aproximadamente a resistência à tração na flexão com a resistência à tração direta;

$f_{c t k \text {,inf }}$ é a resistência característica inferior do concreto à tração direta.

O valor de $f_{c t k \text {,inf }}$ é dado por:

$$
f_{c t k, \mathrm{inf}}=-0,21 \sqrt[3]{f_{c k}^{2}}
$$

sendo $f_{c k}$ a resistência característica do concreto à compressão expresso em MPa. 
Logo, com o auxílio das expressões (4.1) e (4.2) e adotando $\alpha^{\mathrm{I} \Xi}$ igual a 1, podemos calcular a resistência à tração na flexão como sendo:

$$
f_{c t k, f}=-0,21 \cdot \sqrt[3]{40^{2}}=-2,45 M P a
$$

\subsubsection{Comportamento estrutural do modelo básico frente à protensão de pequena excentricidade}

As figuras 4.27 e 4.28 mostram as tensões máximas e mínimas nas fibras superiores e inferiores, respectivamente, para a combinação freqüente das ações que deveriam ter o valor mínimo igual a $-2,45 \mathrm{MPa}$, de forma a respeitar o estado limite de formação de fissura.

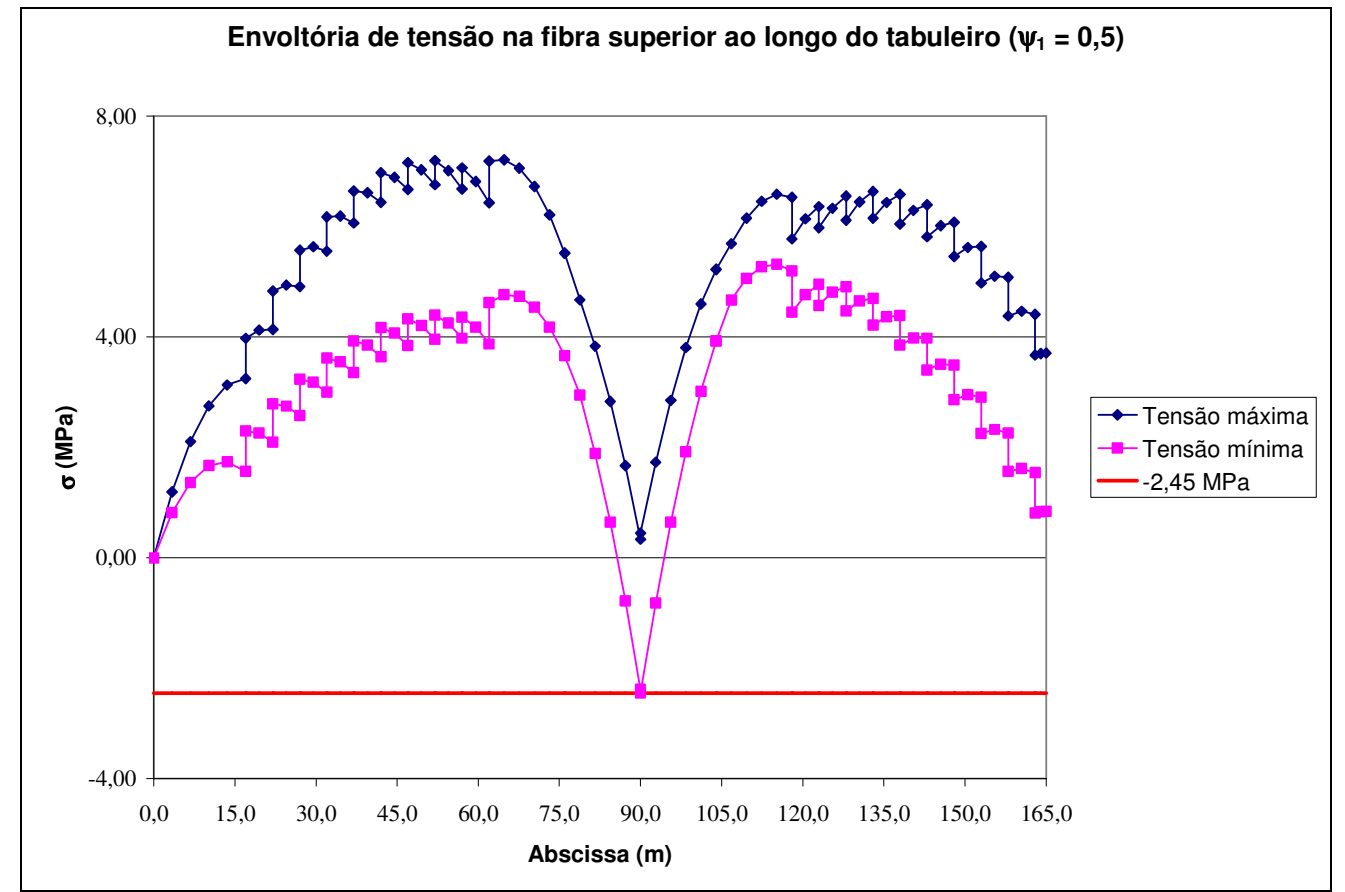

Figura 4.27 - Envoltória de tensão na fibra superior ao longo do tabuleiro para a combinação freqüente das ações (modelo básico).

\footnotetext{
${ }^{\mathrm{IX}} \mathrm{O}$ valor de $\alpha$ igual a 1 se deve às larguras das lajes superior e inferior serem relativamente grande, com isso é razoável assumir que nessas regiões a tração é uniforme.
} 


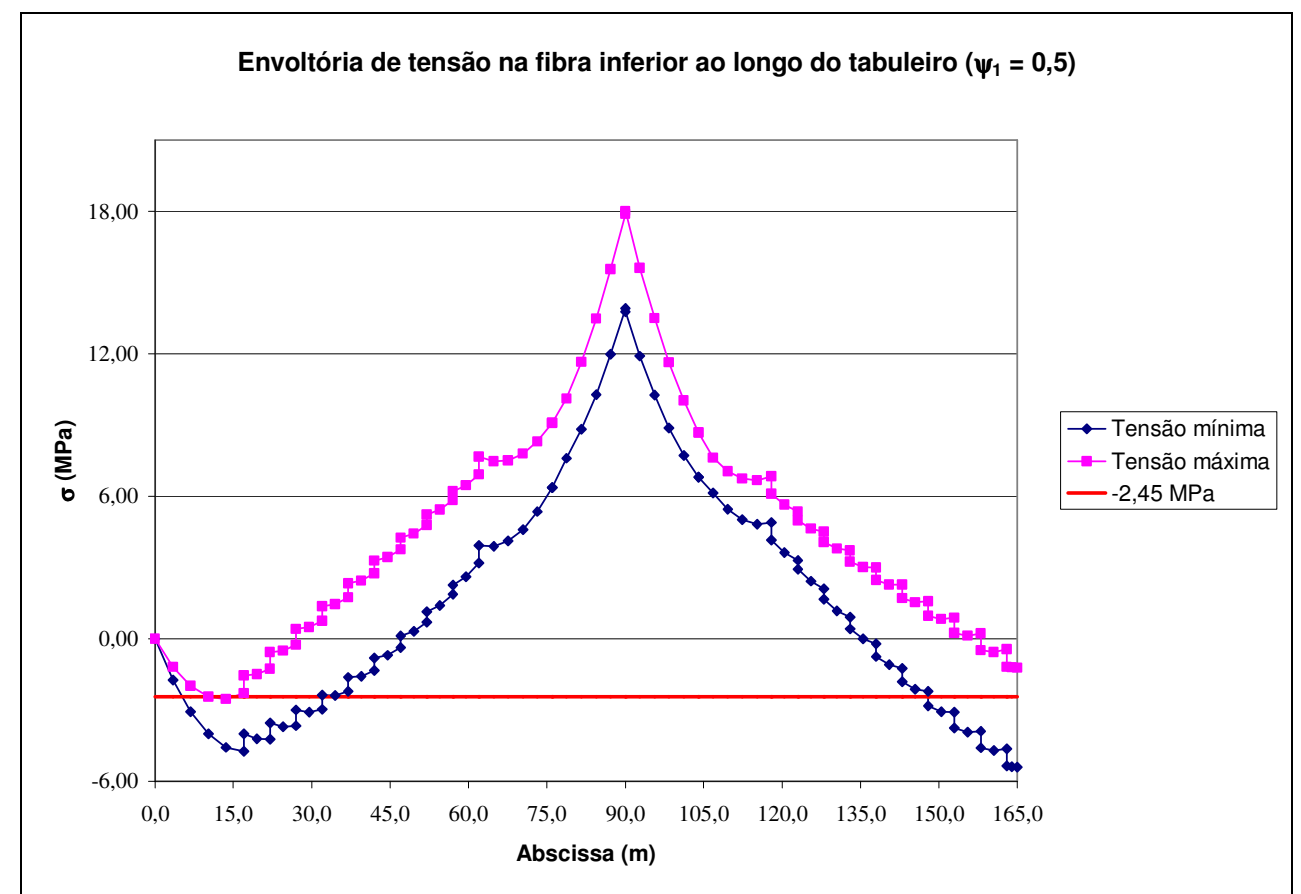

Figura 4.28 - Envoltória de tensão na fibra inferior ao longo do tabuleiro para a combinação freqüente das ações (modelo básico).

As figuras 4.28 e 4.29 mostram as tensões máximas e mínimas nas fibras extremas para a combinação quase permanente das ações que deveriam ser maiores ou iguais a zero, de forma a obedecer ao estado limite de descompressão.

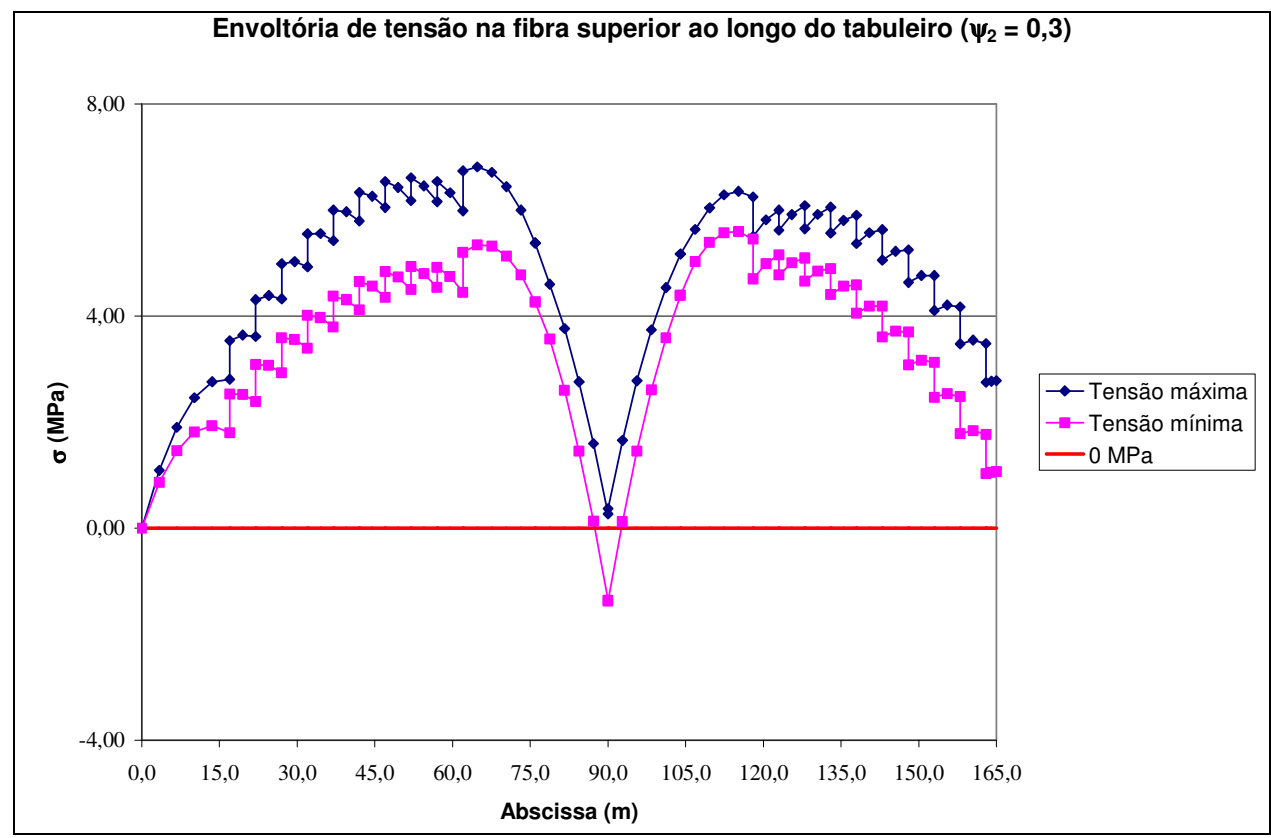

Figura 4.29 - Envoltória de tensão na fibra superior ao longo do tabuleiro para a combinação quase permanente das ações (modelo básico). 


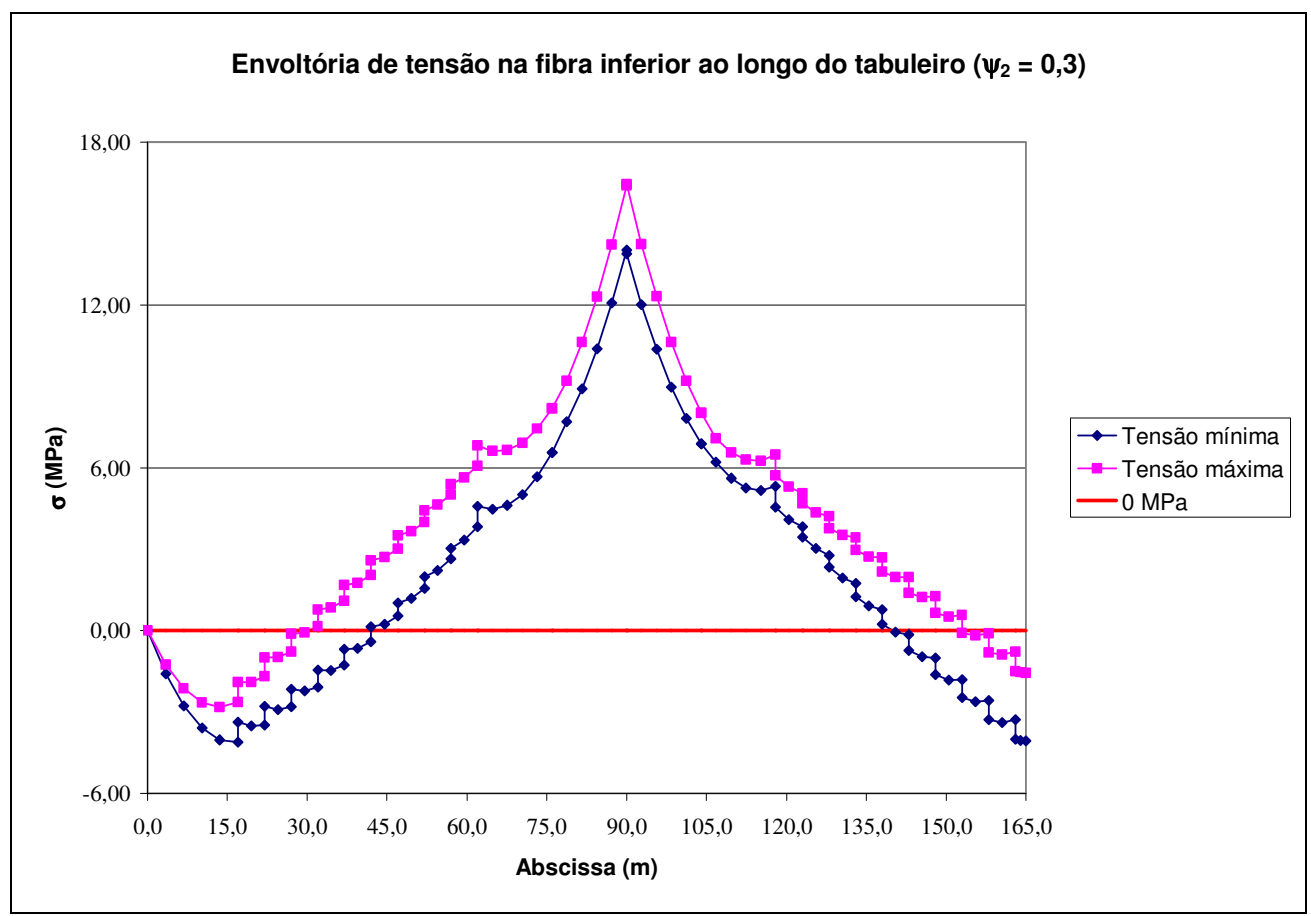

Figura 4.30 - Envoltória de tensão na fibra inferior ao longo do tabuleiro para a combinação quase permanente das ações (modelo básico).

Analisando as figuras 4.27 a 4.30 percebe-se que existem três regiões que podem precisar de protensão interna, um trecho inferior esquerdo do vão lateral, um trecho inferior no meio do vão central e outro superior sobre o apoio intermediário (figura 4.31). Os comprimentos dos cabos internos foram tomados como sendo, aproximadamente, igual ao trecho onde as tensões não respeitam os limites adotados.

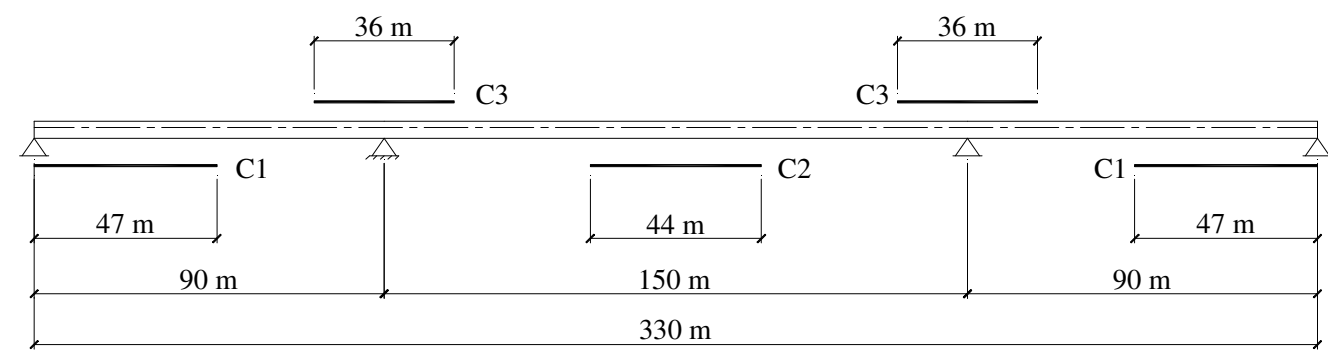

Figura 4.31 - Posição e comprimento da protensão interna adotada no tabuleiro para o modelo básico.

Para o cálculo da protensão interna necessária é preciso avaliar os esforços hiperestáticos que a mesma gera, pois estes modificam as tensões obtidas anteriormente. 
Obviamente, os esforços hiperestáticos dependem da protensão que ainda não foi quantificada, no entanto, por se tratar de uma análise elástica e linear, a superposição de efeitos é válida e a relação entre o momento hiperestático e a força $\mathrm{P}$ se mantêm independente do valor da protensão, ou seja:

$$
\frac{X_{p}(x, P)}{P}=k
$$

Adotando protensão unitária temos:

$$
X_{p}(x, P=1)=k
$$

Substituindo o valor de k da expressão (4.4) na (4.3) temos:

$$
X_{p}(x, P)=P \cdot X_{p}(x, P=1)
$$

Com isso, basta obter o diagrama de momento hiperestático para a protensão unitária para poder determinar a protensão necessária em qualquer seção que se queira. Para tanto, foram realizados mais três carregamentos no modelo computacional que correspondem ao carregamento equivalente dos três cabos assumidos na figura 4.31 com protensão de $1 \mathrm{kN}$ (figura 4.32). Para a adoção das excentricidades foram subtraídas das distâncias do centro de gravidade às fibras extremas $15 \mathrm{~cm}$.

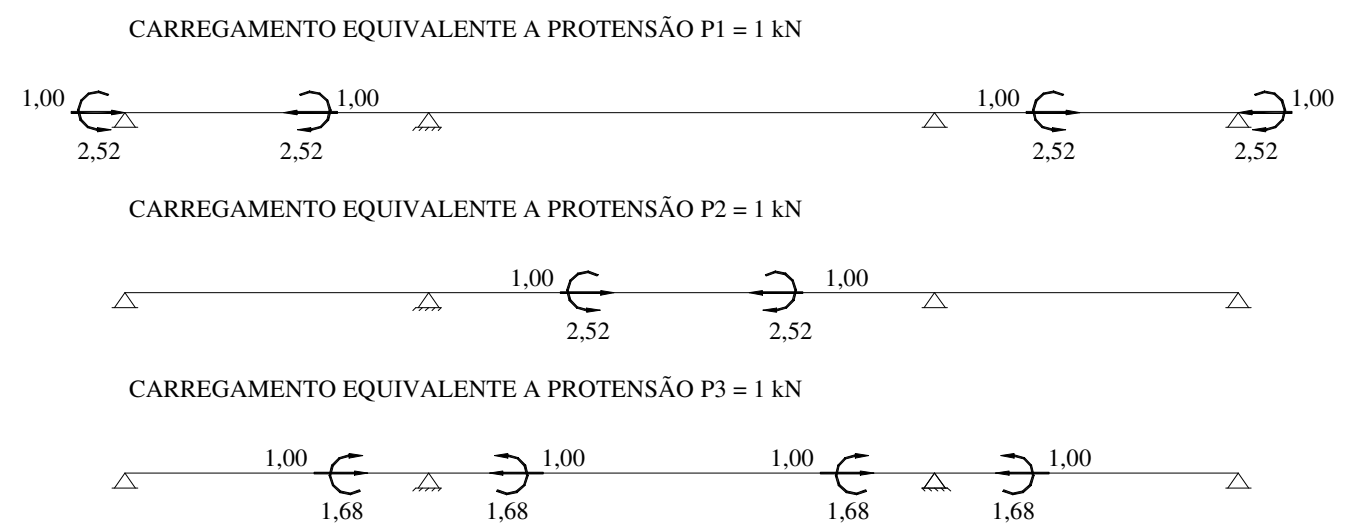

Figura 4.32 - Representação de cada protensão através de carregamento equivalente.

A figura 4.33 apresenta os momentos hiperestáticos referentes à protensão dos cabos $\mathrm{C}_{1}, \mathrm{C}_{2}$ e $\mathrm{C}_{3}$, todos com valor unitário $(1 \mathrm{kN})$. 


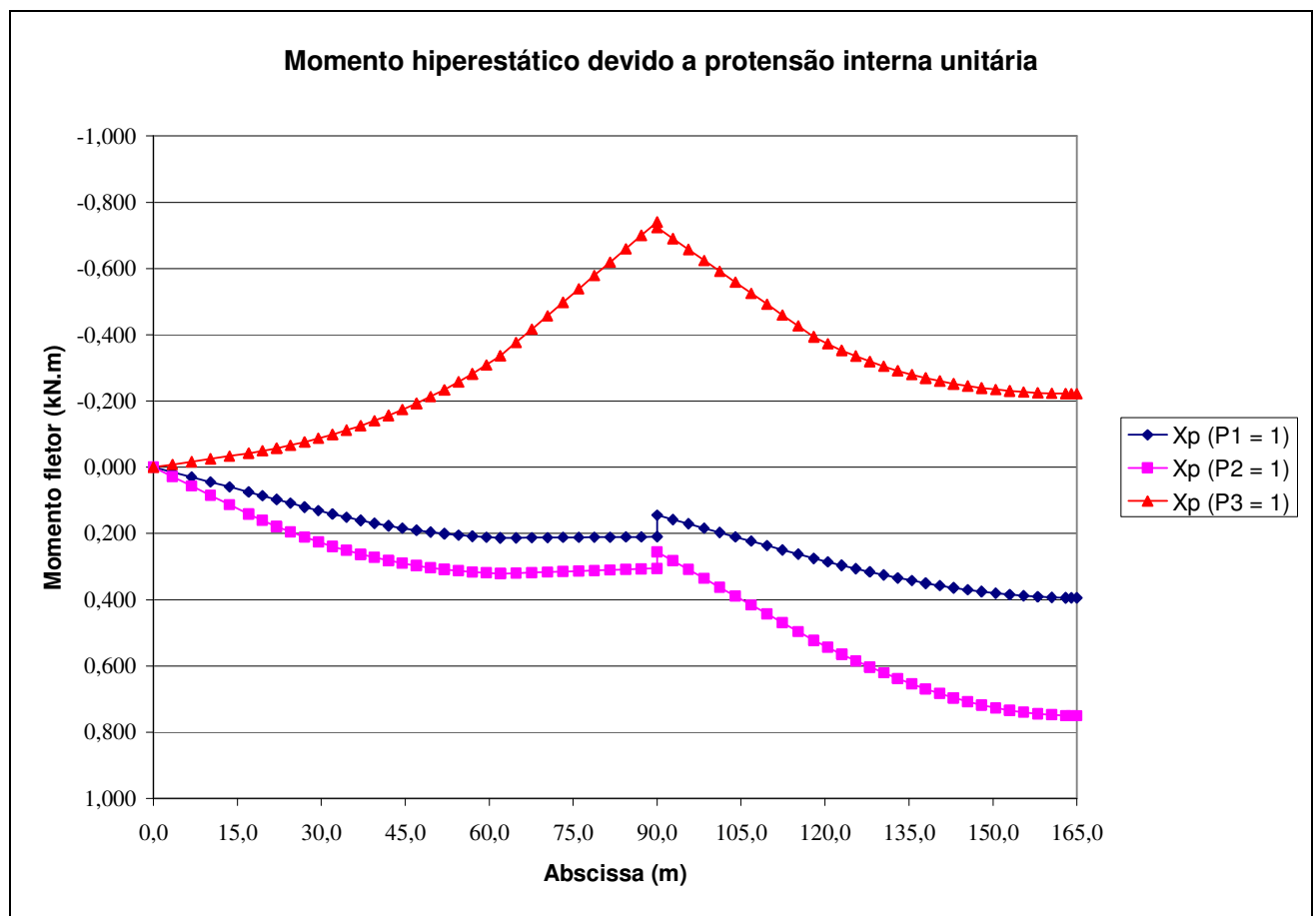

Figura 4.33 - Diagramas de momento hiperestático devido à protensão interna unitária (modelo básico).

Os esforços normais hiperestáticos produzidos são bem pequenos e foram desprezados no cálculo da protensão interna.

O procedimento de cálculo da protensão interna será realizado em duas etapas: na primeira são quantificadas as protensões necessárias nas seções consideradas críticas e na segunda será analisada a envoltória de tensões nas fibras extremas ao longo do tabuleiro, com o objetivo de constatar se o comprimento adotado para cada cabo é adequado.

As seções consideradas críticas são: a imediatamente a esquerda da seção, onde o primeiro cabo do vão lateral é instalado $(\mathrm{x}=17 \mathrm{~m})$, a seção imediatamente a direita do apoio intermediário $(x=90 \mathrm{~m})$ e no meio do vão central $(\mathrm{x}=165 \mathrm{~m})$. A tabela 4.11 possui todas as informações necessárias para a determinação da protensão interna. 
Tabela 4.11 - Seções críticas, tensões de tração a serem combatidas e a relação entre momento hiperestático e protensão (modelo básico).

\begin{tabular}{|c|c|c|c|c|c|c|c|}
\hline \multirow{2}{*}{ Seção } & \multirow{2}{*}{$\begin{array}{c}\text { Posição } \\
\end{array}$} & \multirow{2}{*}{$\begin{array}{c}\text { Fibra } \\
\text { extrema }\end{array}$} & \multicolumn{2}{|c|}{$\sigma_{\text {crítica }}$} & $X_{p 1} / P_{1}$ & $X_{p 2} / P_{2}$ & $X_{p 3} / P_{3}$ \\
& $(\mathrm{~m})$ & analisada & $(\mathrm{MPa})$ & Comb. & $(\mathrm{m})$ & $(\mathrm{m})$ & $(\mathrm{m})$ \\
\hline 1 & 17 & Inferior & $-4,10$ & CQP & 0,075 & 0,142 & $-0,042$ \\
\hline 2 & 165 & Inferior & $-4,06$ & CQP & 0,394 & 0,750 & $-0,222$ \\
\hline $3 \mathrm{~d}$ & 90 & Superior & $-1,37$ & CQP & 0,158 & 0,282 & $-0,691$ \\
\hline
\end{tabular}

CQP - Combinação quase permanente.

CF - Combinação freqüente.

$\sigma_{\text {crítica }}-$ Tensão mínima entre aquela gerada pela CQP e a gerada pela $\mathrm{CF}$, sendo que esta última é somada a $f_{c t k, f}$.

Como em todas as três seções, a combinação que produz a tensão crítica a ser combatida é a quase permanente, é preciso que as protensões $\mathrm{P}_{1}, \mathrm{P}_{2}$ e $\mathrm{P}_{3}$ sejam calculadas de forma a respeitar o estado limite de descompressão, não sendo necessária a análise do estado limite de formação de fissura (que é respeitado automaticamente).

O estado limite de descompressão (nas seções críticas) será obedecido se forem verdadeiras as seguintes inequações:

$$
\begin{aligned}
& \sigma_{\text {crítrica }}(1)+P_{1}\left(\frac{1}{A}+\frac{e-X_{p}\left(1, P_{1}=1\right)}{W_{i}}\right)-P_{2} \frac{X_{p}\left(1, P_{2}=1\right)}{W_{i}}-P_{3} \frac{X_{p}\left(1, P_{3}=1\right)}{W_{i}} \geq 0 \\
& \sigma_{\text {crítica }}(2)-P_{1} \frac{X_{p}\left(2, P_{1}=1\right)}{W_{i}}+P_{2}\left(\frac{1}{A}+\frac{e-X_{p}\left(2, P_{2}=1\right)}{W_{i}}\right)-P_{3} \frac{X_{p}\left(2, P_{3}=1\right)}{W_{i}} \geq 0 \\
& \sigma_{\text {crítica }}(3 d)+P_{1} \frac{X_{p}\left(3 d, P_{1}=1\right)}{W_{s}}+P_{2} \frac{X_{p}\left(3 d, P_{2}=1\right)}{W_{s}}+P_{3}\left(\frac{1}{A}+\frac{e+X_{p}\left(3 d, P_{3}=1\right)}{W_{s}}\right) \geq 0
\end{aligned}
$$

Substituindo os dados da tabela 4.11 nas inequações e o sinal de maior ou igual pela igualdade temos: 


$$
\left\{\begin{array}{l}
-4100+0,325 \cdot P_{1}-0,013 \cdot P_{2}+0,004 \cdot P_{3}=0 \\
-4060-0,037 \cdot P_{1}+0,262 \cdot P_{2}+0,021 \cdot P_{3}=0 \\
-1370+0,009 \cdot P_{1}+0,016 \cdot P_{2}+0,157 \cdot P_{3}=0
\end{array}\right.
$$

Resolvendo o sistema de equações temos:

$$
\left\{\begin{array}{l}
P_{1}=13212,9 k N \\
P_{2}=16861,1 k N \\
P_{3}=6250,4 k N
\end{array}\right.
$$

Assumindo a tensão inicial do aço de protensão interna igual a $75 \% f_{\mathrm{ptk}} \mathrm{e}$ arbitrando, ainda, as perdas em $20 \%$, temos que a protensão útil de uma cordoalha de 12,5 mm é igual a 112,5 kN. Logo, a quantidade de cordoalhas em cada cabo interno é igual a:

$$
\left\{\begin{array}{l}
n_{1}=\frac{13212,9}{112,5}=118 \text { cordoalhas } \Rightarrow C_{1} \equiv 10 \text { cabos de } 12 \phi 12,5 \mathrm{~mm} \\
n_{2}=\frac{16861,1}{112,5}=150 \text { cordoalhas } \Rightarrow C_{2} \equiv 13 \text { cabos de } 12 \phi 12,5 \mathrm{~mm} \\
n_{3}=\frac{6250,4}{112,5}=56 \text { cordoalhas } \Rightarrow C_{3} \equiv 5 \text { cabos de } 12 \phi 12,5 \mathrm{~mm}
\end{array}\right.
$$

A protensão efetiva em cada cabo interno é igual a:

$$
\left\{\begin{array}{l}
P_{1}=10 \cdot 12 \cdot 112,5=13500 \mathrm{kN} \\
P_{2}=13 \cdot 12 \cdot 112,5=17550 \mathrm{kN} \\
P_{3}=5 \cdot 12 \cdot 112,5=6750 \mathrm{kN}
\end{array}\right.
$$

Analisando a envoltória de tensões, considerando a protensão interna, nas fibras superiores (figura 4.34) e inferiores (figura 4.35), respectivamente, para a combinação freqüente das ações, nota-se que o estado limite de formação de fissura é respeitado. 


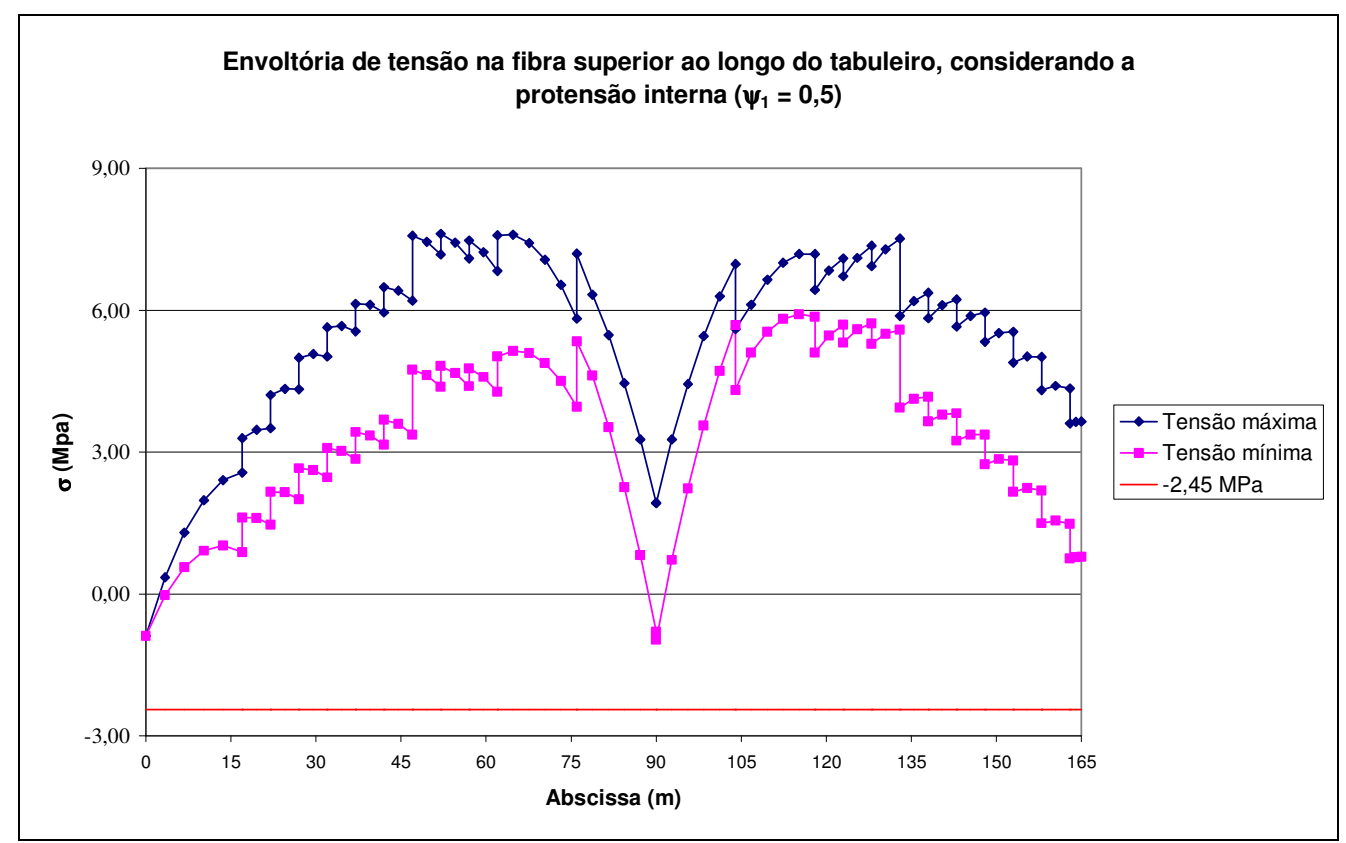

Figura 4.34 - Envoltória de tensão na fibra superior ao longo do tabuleiro, para a CF, considerando a protensão interna (modelo básico).

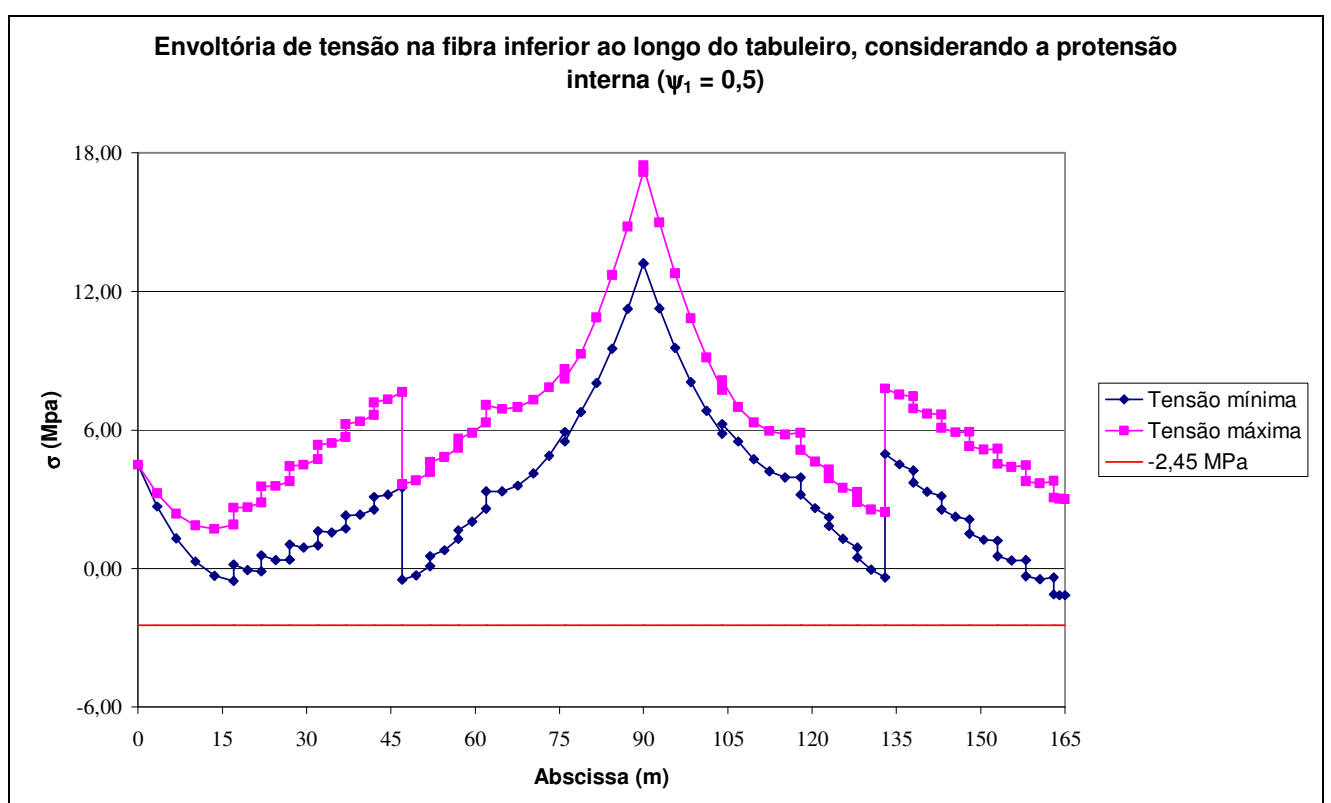

Figura 4.35 - Envoltória de tensão na fibra inferior ao longo do tabuleiro, para a CF, considerando a protensão interna (modelo básico).

Quanto ao estado limite de descompressão para a CQP, percebe-se que existem tensões de tração na fibra superior da viga na região do apoio extremo (figura 4.36), entretanto essa situação pode ser facilmente corrigida através da 
redução ou eliminação da excentricidade da protensão 1 nesta região. Já as tensões na fibra inferior (figura 4.37) respeitam o ELS-D.

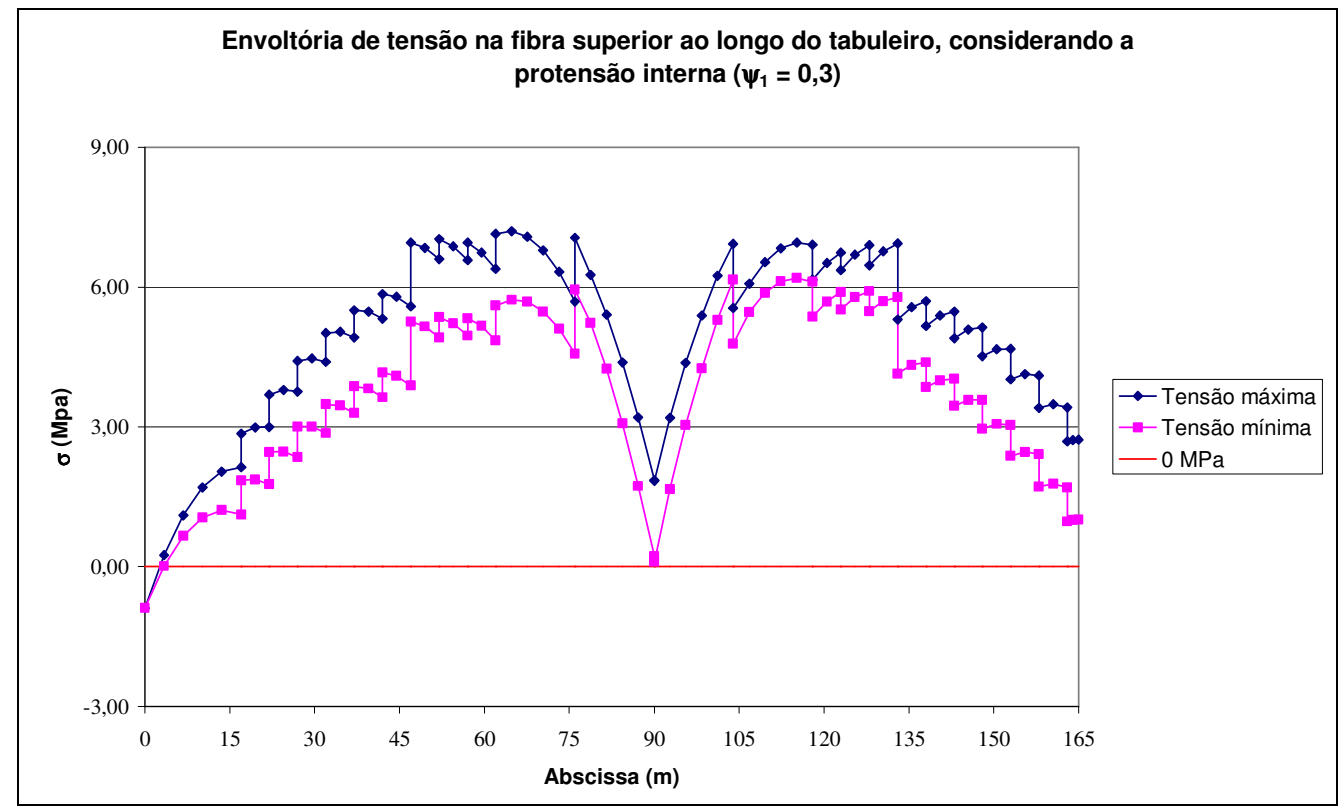

Figura 4.36 - Envoltória de tensão na fibra superior ao longo do tabuleiro, para a CQP, considerando a protensão interna (modelo básico).

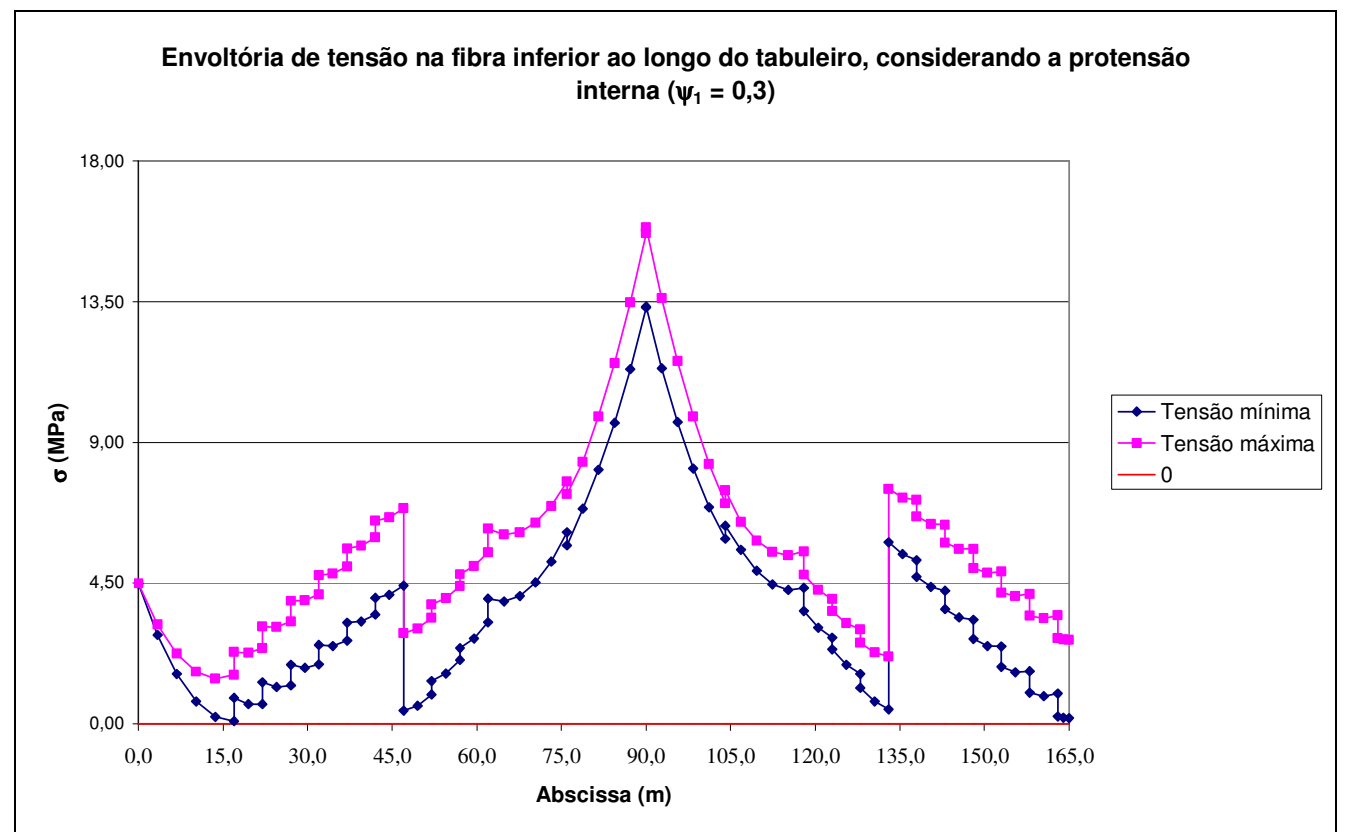

Figura 4.37 - Envoltória de tensão na fibra inferior ao longo do tabuleiro para a CQP, considerando a protensão interna (modelo básico).

De posse da protensão de cada cabo interno, podemos traçar o diagrama de momento hiperestático de protensão (figura 4.38). 


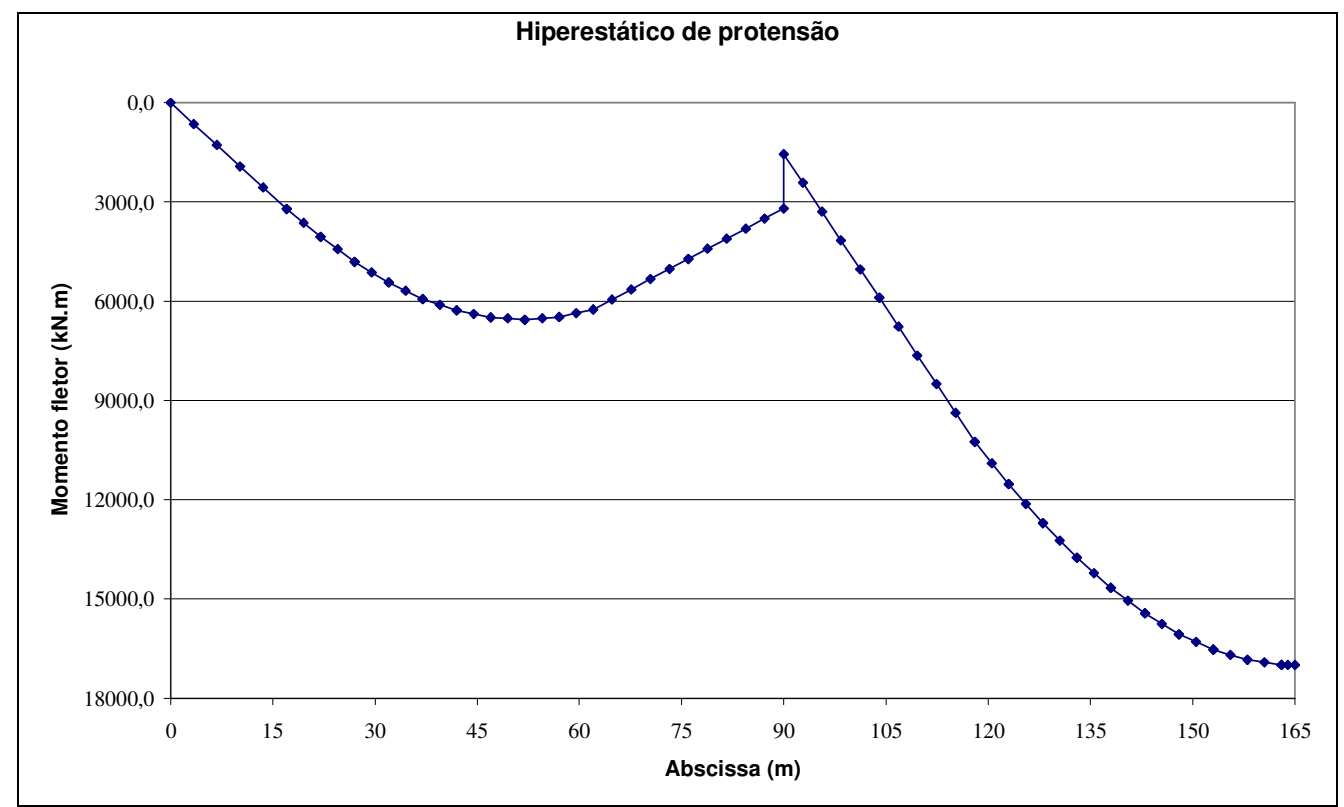

Figura 4.38 - Momento hiperestático de protensão (modelo básico).

O diagrama de momento fletor e a sua envoltória com a consideração do hiperestático de protensão estão indicados na figura 4.39.

A protensão interna reduz as tensões dos cabos no extradorso, o que permite reduzir a área dos tirantes (pois $\sigma_{\text {máx }}<\sigma_{\text {adm }}$ ). A tabela 4.12 apresenta a área de aço extradorsal, considerando o efeito da protensão interna.

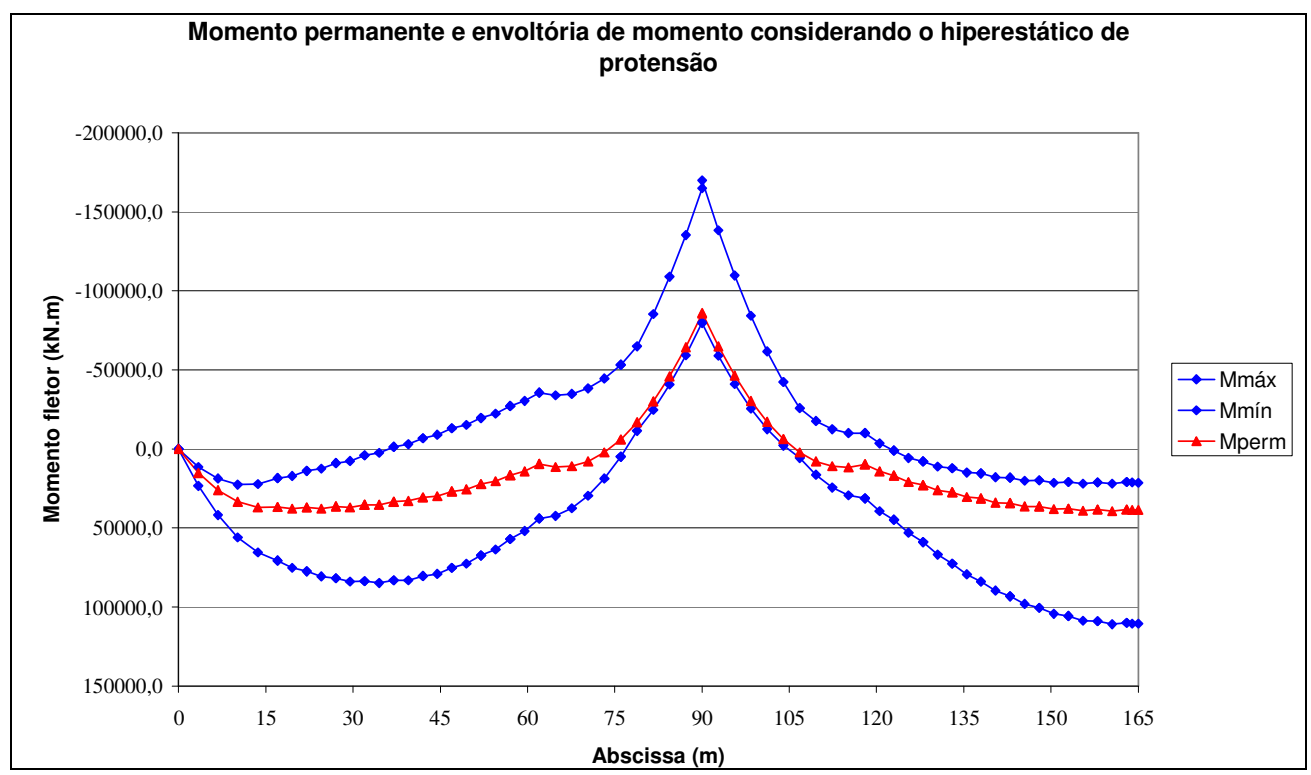

Figura 4.39 - Diagrama de momento fletor no tabuleiro devido ao carregamento permanente e envoltória de momento fletor, considerando o hiperestático de protensão (modelo básico). 
Tabela 4.12 - Área de aço extradorsal considerando a protensão interna (modelo básico).

\begin{tabular}{|c|c|c|c|c|c|}
\hline \multirow{2}{*}{ Grupo } & \multirow{2}{*}{ Cabos } & \multicolumn{2}{|c|}{ Mod. básico } & \multicolumn{2}{c|}{$\begin{array}{c}\text { Mod. básico com } \\
\text { protensão interna }\end{array}$} \\
\cline { 3 - 6 } & $\begin{array}{c}\mathrm{A}_{\mathrm{p}} \\
\left(\mathrm{cm}^{2}\right)\end{array}$ & $\begin{array}{c}\text { Peso } \\
(\mathrm{Ton})\end{array}$ & $\begin{array}{c}\mathrm{A}_{\mathrm{p}} \\
\left(\mathrm{cm}^{2}\right)\end{array}$ & $\begin{array}{c}\text { Peso } \\
(\text { Ton })\end{array}$ \\
\hline 1 & 1 a 4 & 80,37 & 7,81 & 79,32 & 7,71 \\
\hline 2 & 5 a 8 & 39,57 & 4.44 & 39,02 & 4,37 \\
\hline 3 & 9 a 12 & 44,65 & 5,68 & 44,03 & 5,60 \\
\hline 4 & 13 a 16 & 49,25 & 7,01 & 48,49 & 6,91 \\
\hline 5 & 17 a 20 & 53,54 & 8,45 & 52,61 & 8,30 \\
\hline 6 & 21 a 24 & 57,64 & 9,98 & 56,65 & 9,81 \\
\hline 7 & 25 a 28 & 61,62 & 11,62 & 60,67 & 11,44 \\
\hline 8 & 29 a 32 & 65,34 & 13,34 & 64,50 & 13,17 \\
\hline 9 & 33 a 36 & 68,93 & 15,14 & 68,18 & 14,98 \\
\hline 10 & 37 a 40 & 72,35 & 17,02 & 71,69 & 16,86 \\
\hline
\end{tabular}

Com a redução da área de aço extradorsal em 1,3\%, os esforços no tabuleiro também se modificam, mas como esse efeito é pequeno, pode-se assumir que a protensão interna respeita os estados limites de serviço para a condição de protensão limitada.

Em relação ao modelo sem a protensão interna, a flecha no tabuleiro é reduzida em $12 \%$, passando de $20,4 \mathrm{~cm}$ para $18,0 \mathrm{~cm}$.

\subsubsection{Comportamento estrutural do modelo com $80 \%$ de compensação das cargas permanentes frente à protensão de pequena excentricidade}

O cálculo da protensão interna no modelo $5 \mathrm{c}$ foi realizado de forma semelhante ao modelo básico.

As figuras 4.40 a 4.43 mostram as envoltórias de tensão nas fibras extremas para as combinações quase permanente e freqüente. 


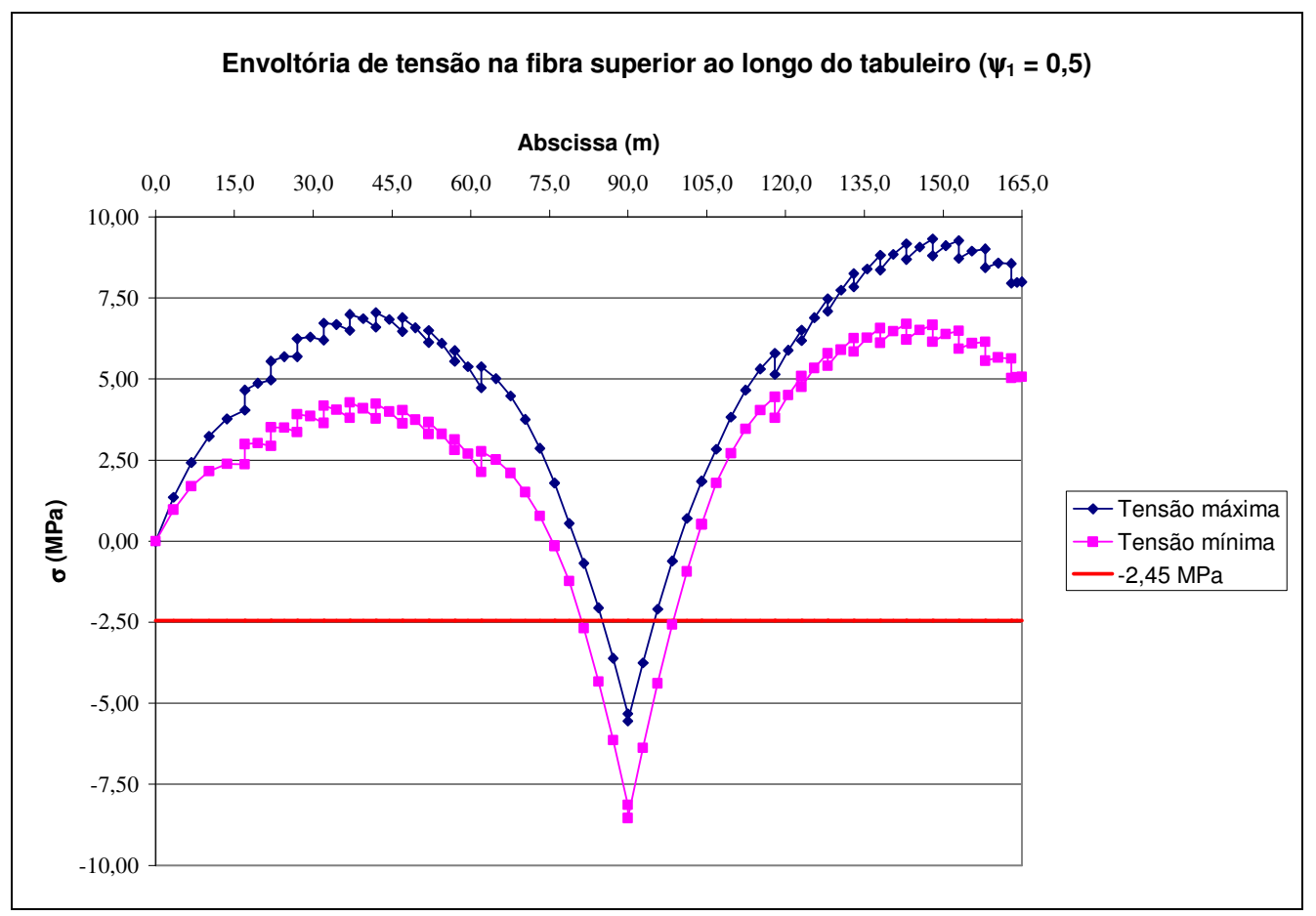

Figura 4.40 - Envoltória de tensão na fibra superior ao longo do tabuleiro para a combinação freqüente das ações (modelo 5c).

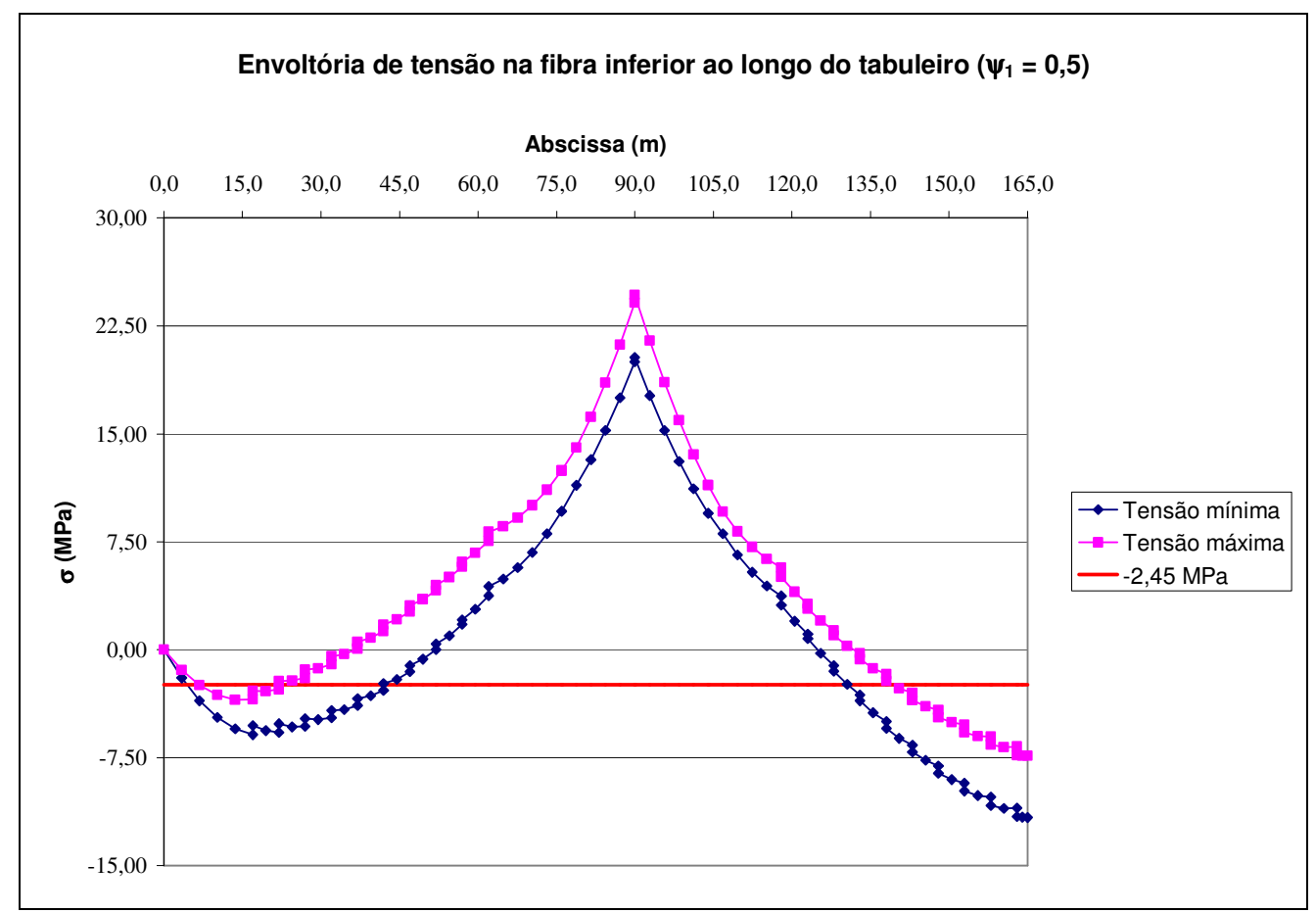

Figura 4.41 - Envoltória de tensão na fibra inferior ao longo do tabuleiro para a combinação freqüente das ações (modelo 5c). 


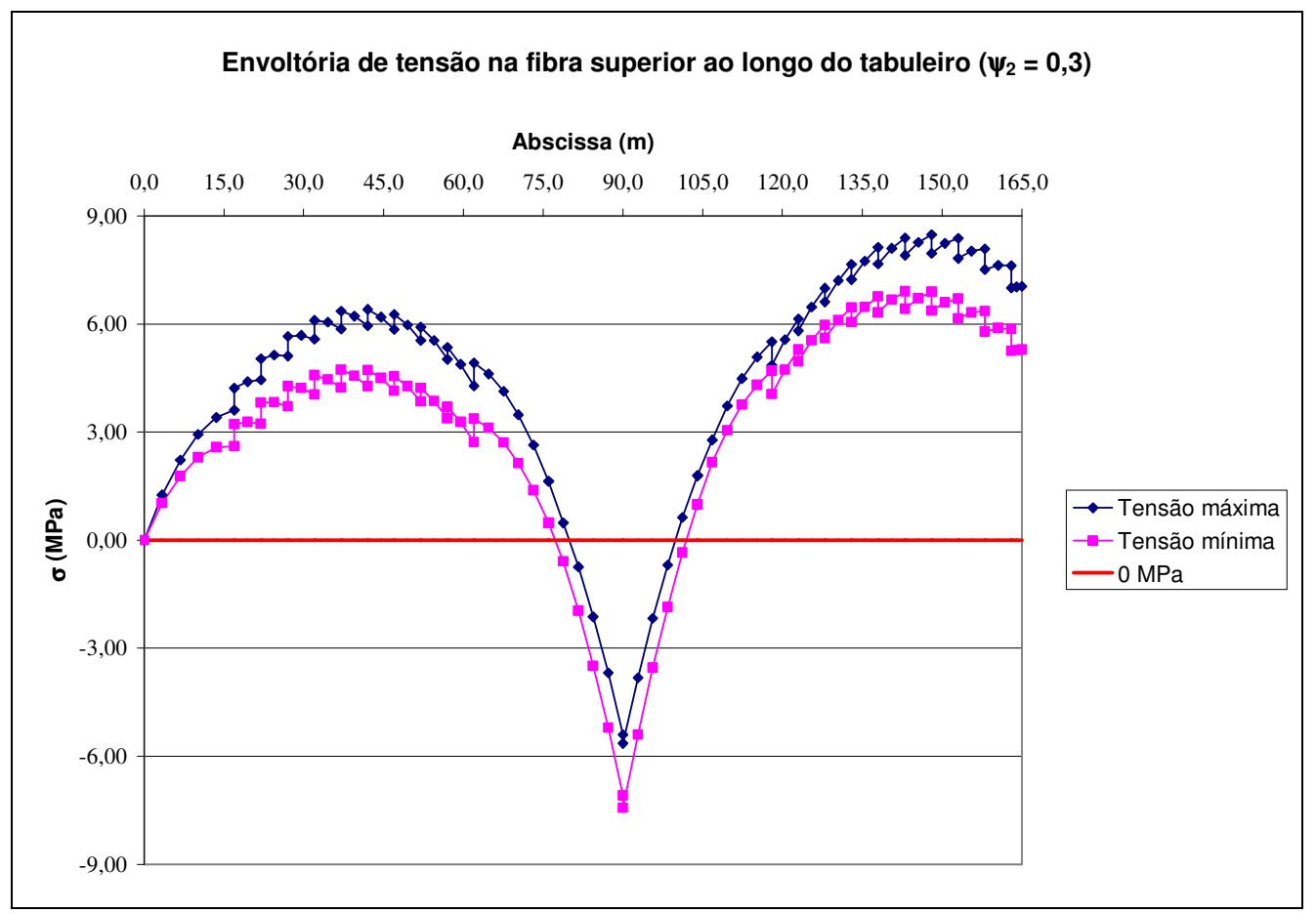

Figura 4.42 - Envoltória de tensão na fibra superior ao longo do tabuleiro para a combinação quase permanente das ações (modelo 5c).

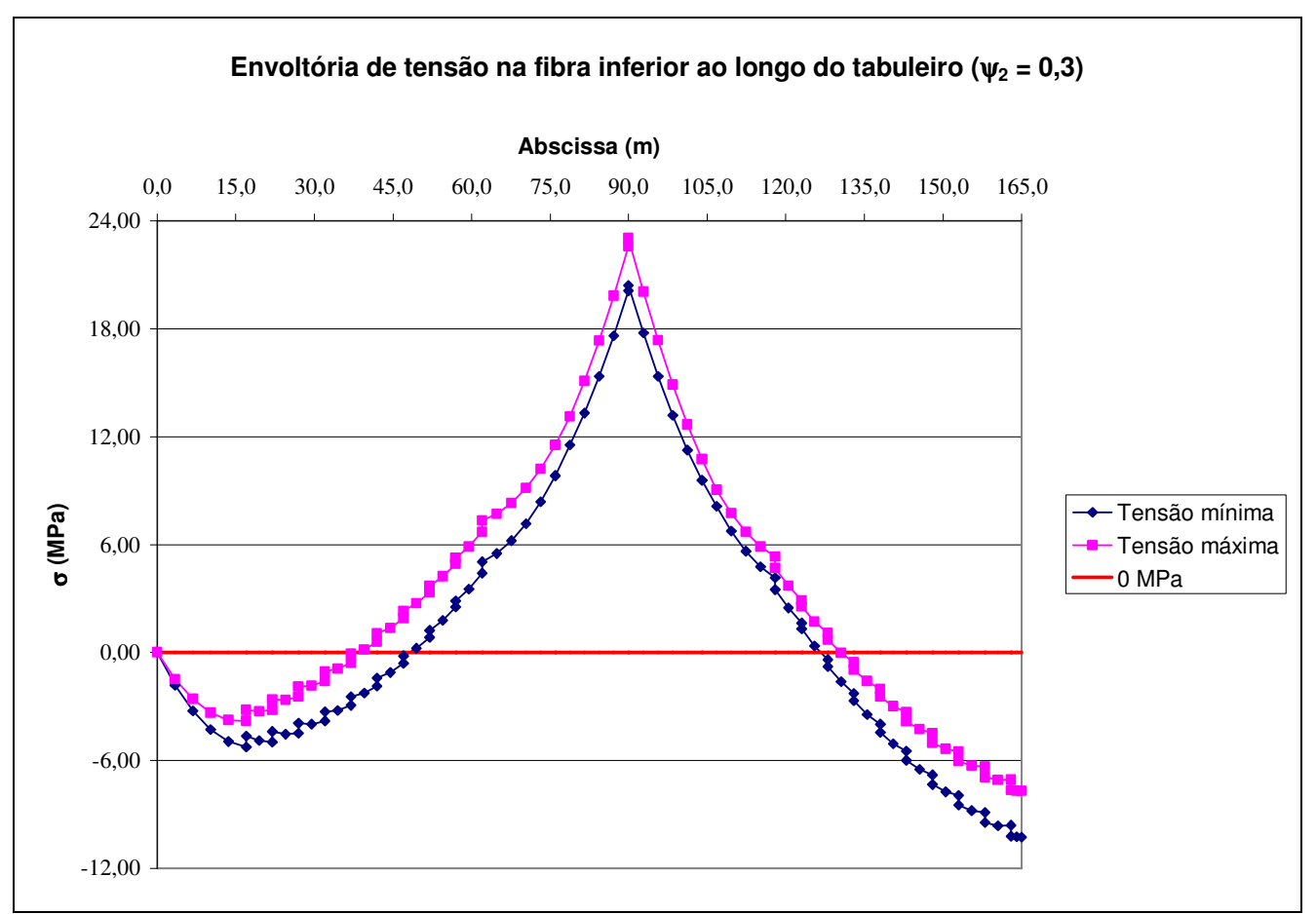

Figura 4.43 - Envoltória de tensão na fibra inferior ao longo do tabuleiro para a combinação quase permanente das ações (modelo 5c). 
Ao analisar as tensões no tabuleiro, nota-se que os cabos devem ter comprimentos maiores em relação ao modelo básico, pelo menos, naqueles referentes à $\mathrm{C}_{1} \mathrm{e}_{2}$. Esse aumento no comprimento dos cabos inferiores tem o efeito desfavorável de aumentar os momentos hiperestáticos positivos, o que resulta em acréscimo da área de aço necessária.

Uma possibilidade para reduzir esse efeito negativo é utilizar cabos com diferentes comprimentos, o que foi realizado no cálculo da protensão deste modelo. A figura 4.44 apresenta o traçado dos cabos considerados.

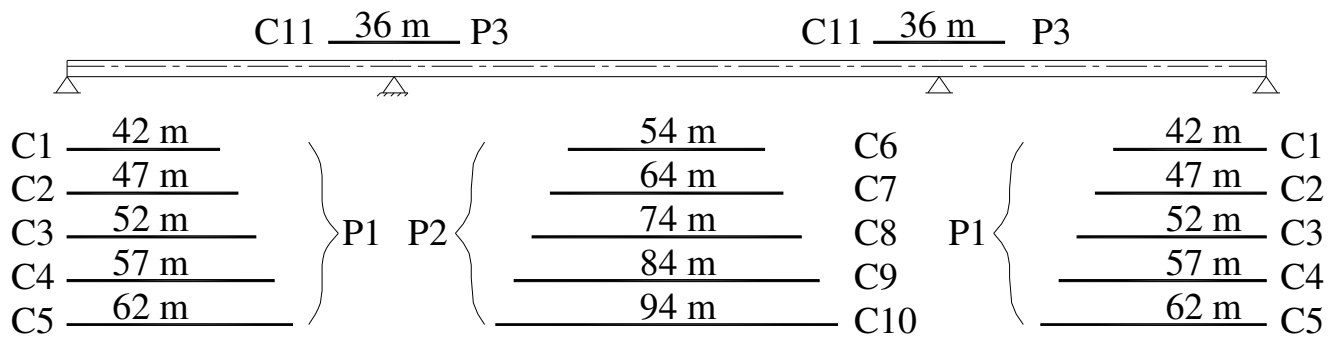

Figura 4.44 - Posição e comprimento da protensão interna adotada no tabuleiro para o modelo $5 \mathrm{c}$.

Calculando a protensão interna, de forma semelhante ao modelo básico, chegamos as seguintes protensões:

$$
\left\{\begin{array}{l}
P_{1}=3 \cdot 12 \cdot 112,5=4050 \mathrm{kN}(3 \text { cabos de } 12 \phi 12,5 \mathrm{~mm}) \\
P_{2}=7 \cdot 12 \cdot 112,5=9450 \mathrm{kN}(7 \text { cabos de } 12 \phi 12,5 \mathrm{~mm}) \\
P_{3}=26 \cdot 12 \cdot 112,5=35100 \mathrm{kN}(26 \text { cabos de } 12 \phi 12,5 \mathrm{~mm})
\end{array}\right.
$$

Ressalta-se que $\mathrm{P}_{1}$ e $\mathrm{P}_{2}$ são as protensões do grupo de cabos $\mathrm{C}_{1}$ a $\mathrm{C}_{5}$ e $\mathrm{C}_{6}$ a $\mathrm{C}_{10}$, respectivamente. Existindo assim, seções do vão lateral que possuem 15 cabos e do vão central com 35 cabos.

As envoltórias de tensões, considerando os efeitos da protensão interna, são mostradas nas figuras 4.45 a 4.48 . 


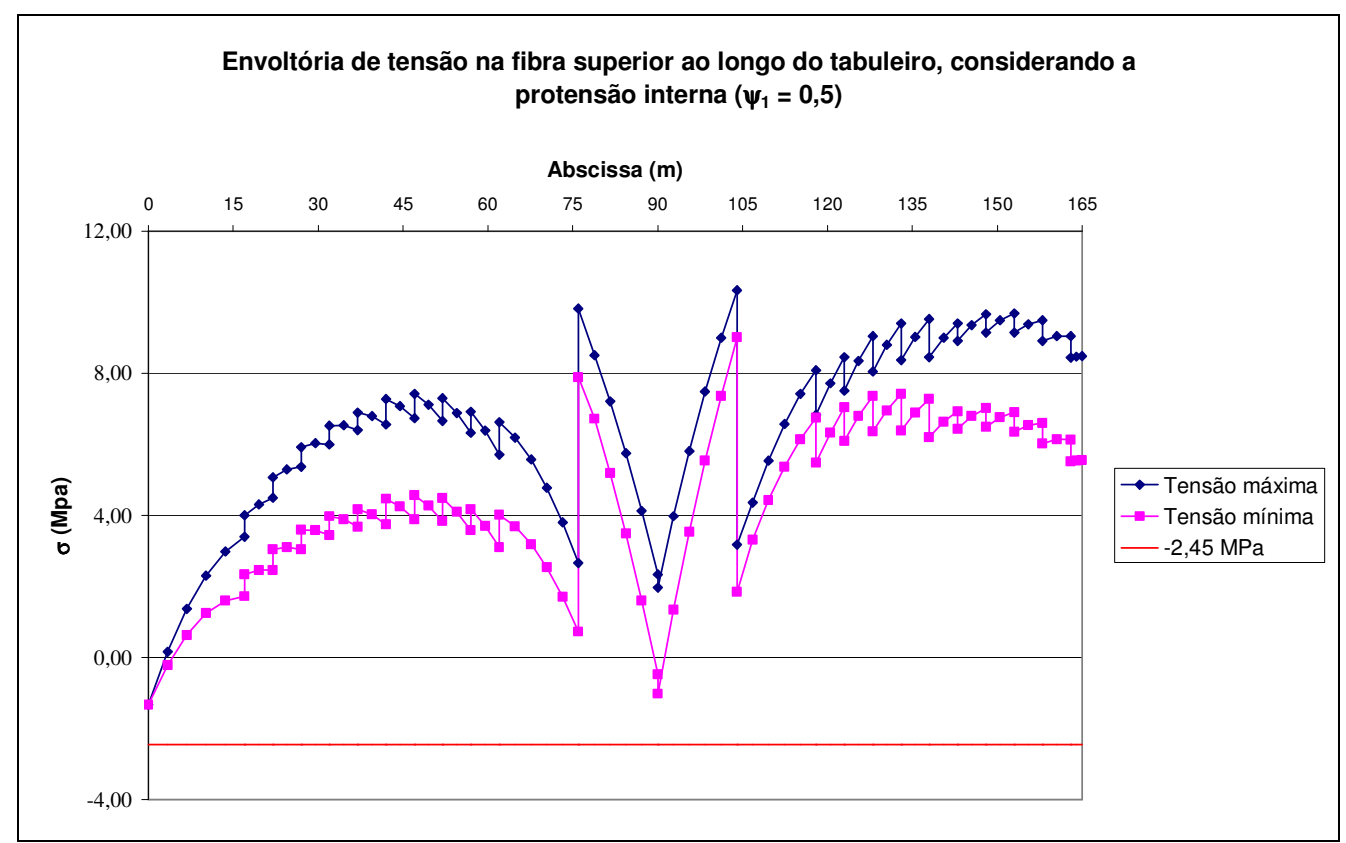

Figura 4.45 - Envoltória de tensão na fibra superior ao longo do tabuleiro para a combinação freqüente das ações, considerando a protensão interna (modelo 5c).

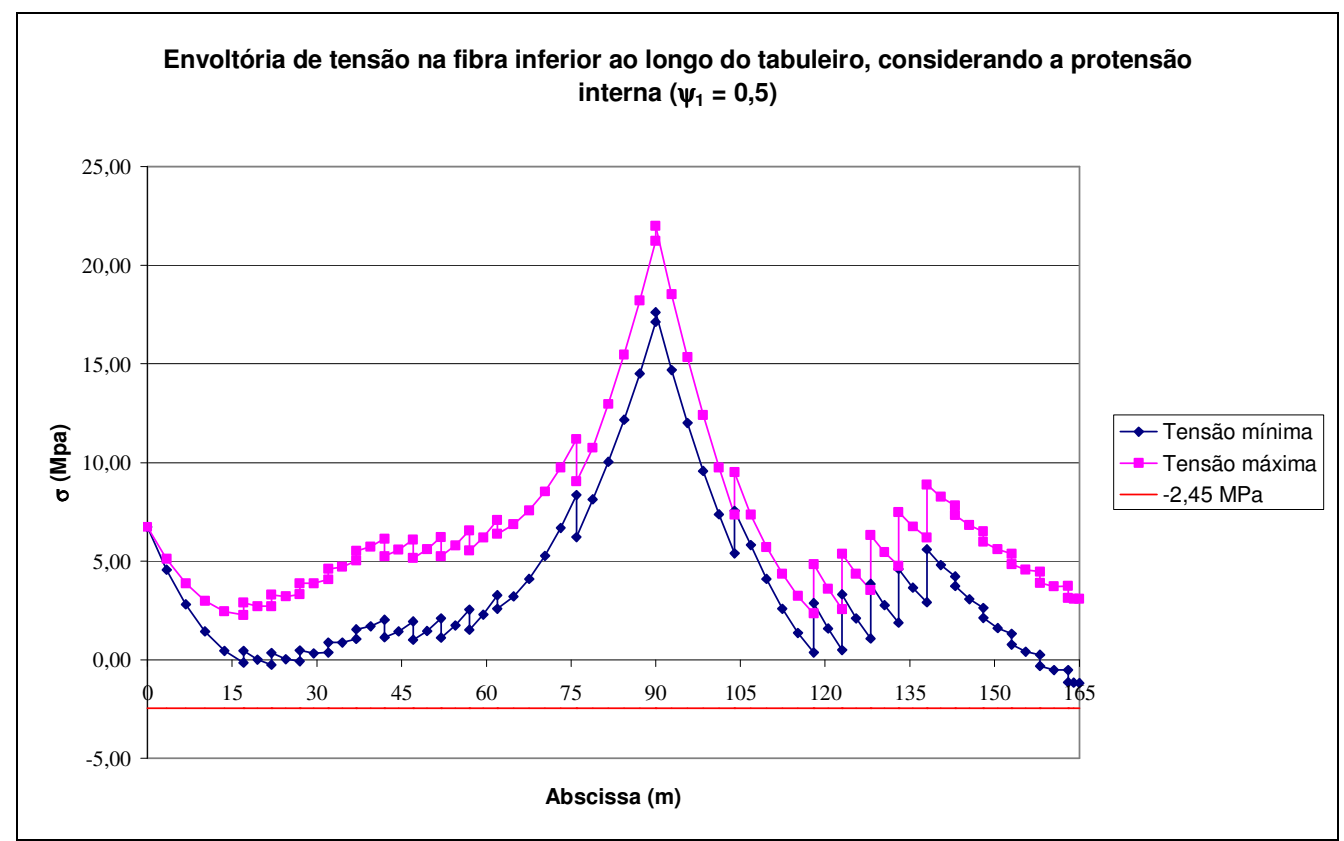

Figura 4.46 - Envoltória de tensão na fibra inferior ao longo do tabuleiro para a combinação freqüente das ações, considerando a protensão interna (modelo 5c). 


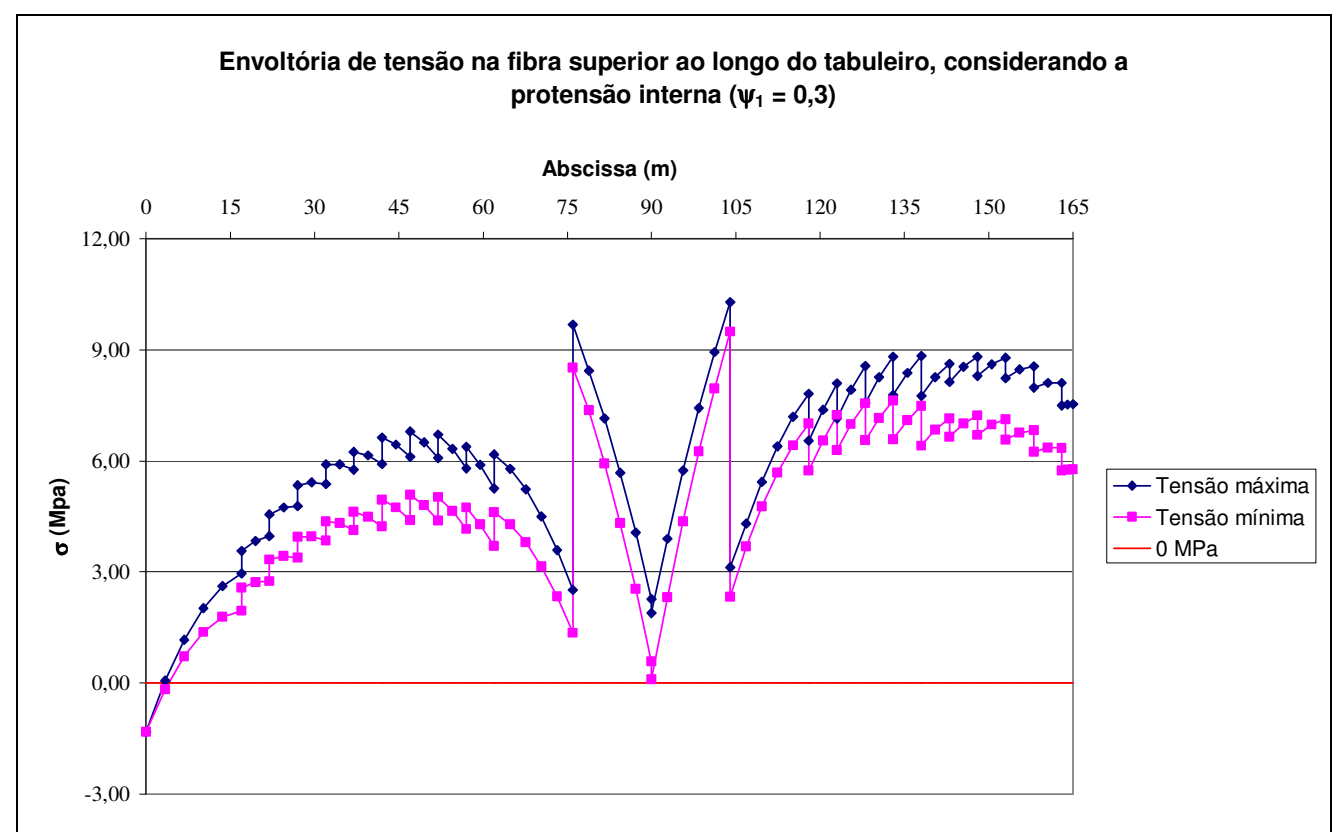

Figura 4.47 - Envoltória de tensão na fibra superior ao longo do tabuleiro para a combinação quase permanente das ações, considerando a protensão interna (modelo $5 \mathrm{c})$.

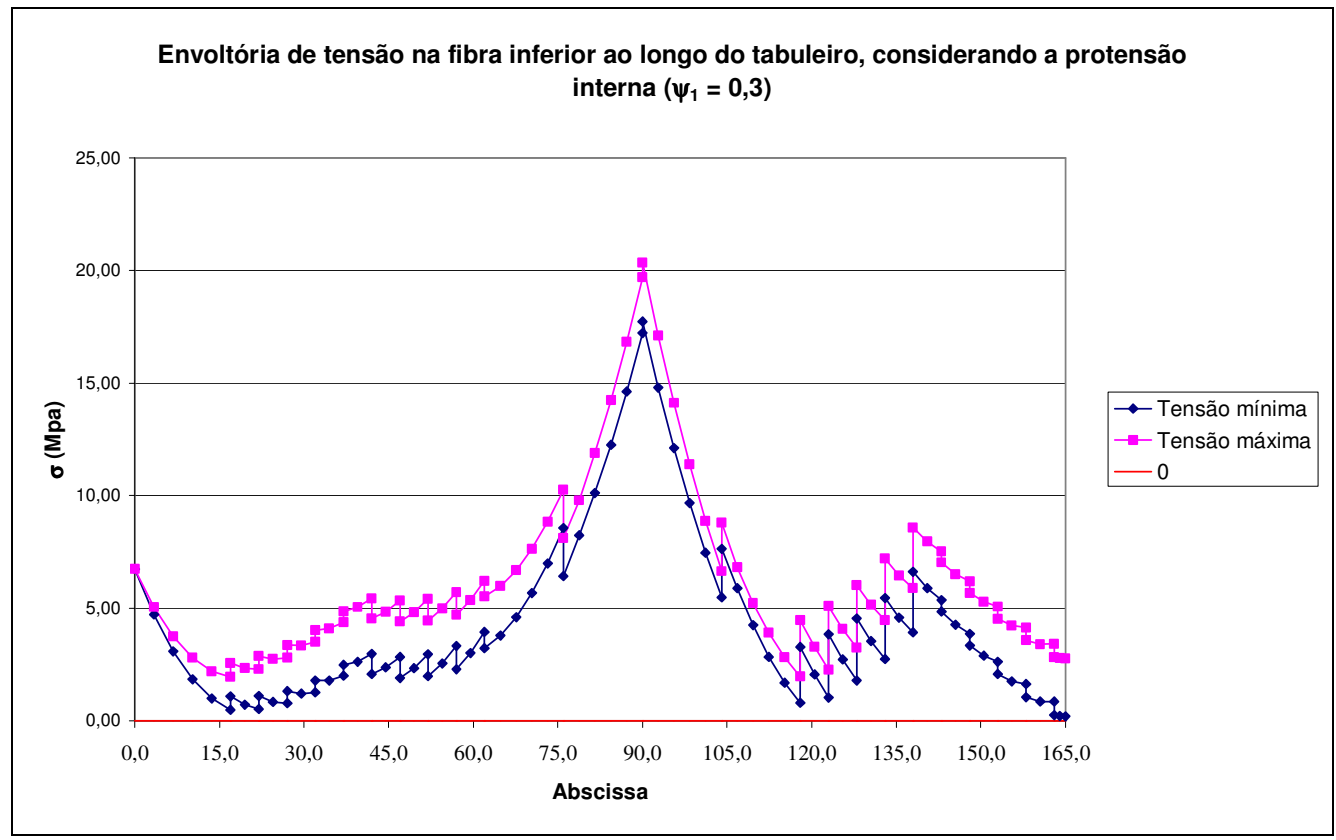

Figura 4.48 - Envoltória de tensão na fibra inferior ao longo do tabuleiro para a combinação quase permanente das ações, considerando a protensão interna (modelo $5 c)$.

Analisando as tensões em serviço, percebe-se que a única região onde a protensão limitada não se verifica é na região do apoio, que conforme já foi discutido, é simples de se corrigir. 
O momento hiperestático de protensão é apresentado na figura 4.49.

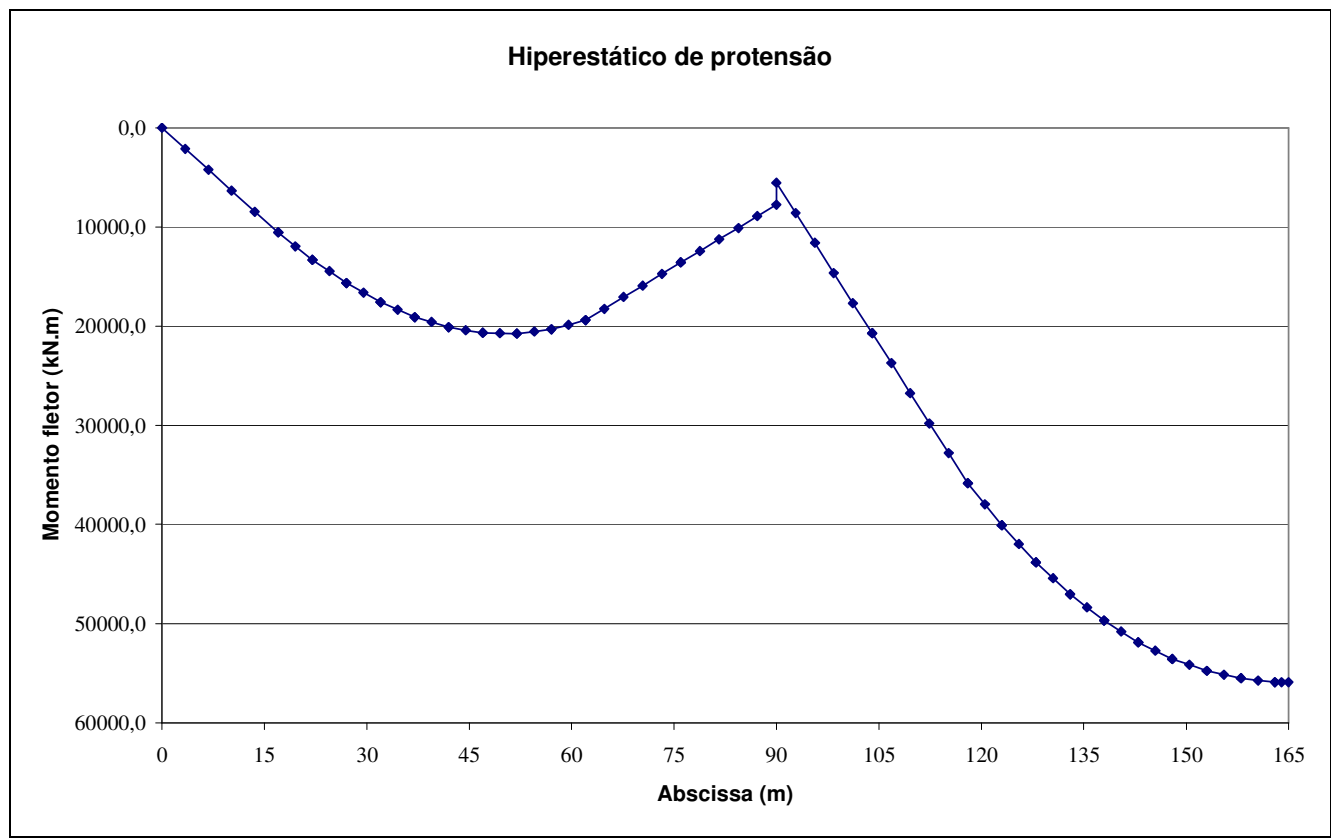

Figura 4.49 - Momento hiprestático de protensão (modelo 5c).

O diagrama de momento fletor e a sua envoltória, com a consideração do hiperestático de protensão, estão indicados na figura 4.50.

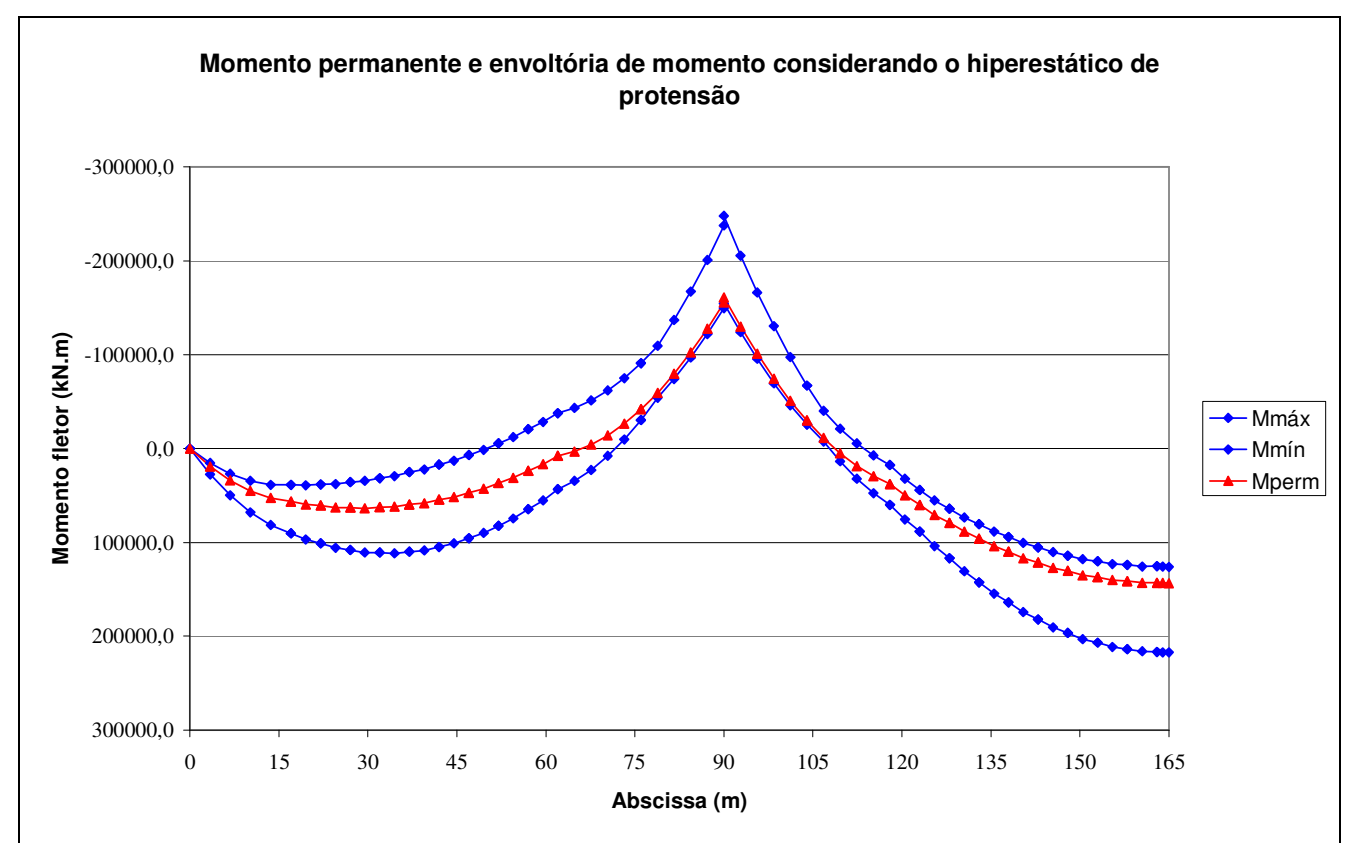

Figura 4.50 - Diagrama de momento fletor no tabuleiro devido ao carregamento permanente e envoltória de momento fletor considerando o hiperestático de protensão (modelo 5c). 
A área de aço extradorsal ao considerar o efeito da protensão interna diminui em $6,3 \%$ e o seu peso em $6,1 \%$ (tabela 4.13 ).

Tabela 4.13 - Área de aço extradorsal considerando a protensão interna (modelo 5c).

\begin{tabular}{|c|c|c|c|c|c|}
\hline \multirow{2}{*}{ Grupo } & \multirow{2}{*}{ Cabos } & \multicolumn{2}{|c|}{ Modelo 5c } & \multicolumn{2}{c|}{$\begin{array}{c}\text { Modelo 5c com } \\
\text { protensão interna }\end{array}$} \\
\cline { 3 - 6 } & & $\begin{array}{c}\mathrm{A}_{\mathrm{p}} \\
\left(\mathrm{cm}^{2}\right)\end{array}$ & $\begin{array}{c}\text { Peso } \\
(\mathrm{Ton})\end{array}$ & $\begin{array}{c}\mathrm{A}_{\mathrm{p}} \\
\left(\mathrm{cm}^{2}\right)\end{array}$ & $\begin{array}{c}\text { Peso } \\
(\text { Ton })\end{array}$ \\
\hline 1 & 1 a 4 & 69,38 & 16,87 & 64,23 & 15,62 \\
\hline 2 & 5 a 8 & 34,08 & 9,55 & 31,57 & 8,85 \\
\hline 3 & 9 a 12 & 38,32 & 12,19 & 35,49 & 11,28 \\
\hline 4 & 13 a 16 & 42,09 & 14,99 & 39,25 & 13,98 \\
\hline 5 & 17 a 20 & 45,70 & 18,02 & 42,71 & 16,84 \\
\hline 6 & 21 a 24 & 49,10 & 21,25 & 46,03 & 19,92 \\
\hline 7 & 25 a 28 & 52,38 & 24,70 & 49,25 & 23,22 \\
\hline 8 & 29 a 32 & 55,43 & 28,29 & 52,27 & 26,67 \\
\hline 9 & 33 a 36 & 58,31 & 32,02 & 55,24 & 30,34 \\
\hline 10 & 37 a 40 & 61,09 & 35,93 & 58,04 & 34,13 \\
\hline
\end{tabular}

Em relação ao modelo sem a protensão interna, a flecha no tabuleiro é reduzida em $37 \%$, passando de $33,5 \mathrm{~cm}$ para $21,2 \mathrm{~cm}$.

A tabela 4.14 mostra a comparação entre o peso de aço protendido dos modelos 5a e 5c. Percebe-se que, embora o modelo 5c necessite de mais cabos internos, a área de aço de protensão total é menor neste.

Tabela 4.14 - Peso de aço de protensão (modelo 5a e 5c).

\begin{tabular}{|c|c|c|c|c|c|c|}
\hline \multirow{2}{*}{ Modelo } & \multicolumn{2}{|c|}{ Extradorso } & \multicolumn{2}{|c|}{ Interno } & \multicolumn{2}{c|}{ Total } \\
\cline { 2 - 7 } & Ton & $\%$ & Ton & $\%$ & Ton & $\%$ \\
\hline $5 \mathrm{a}$ & 1004,9 & - & 17,5 & - & 1022,4 & - \\
\hline $5 \mathrm{c}$ & 855,2 & 85,1 & 43,5 & 248,5 & 898,7 & 87,9 \\
\hline
\end{tabular}

\subsection{VERIFICAÇÃO DA SEGURANÇA DOS CABOS NO EXTRADORSO DO MODELO BÁSICO AO ESTADO LIMITE ÚLTIMO}

Ainda que no estado limite último, a estrutura de concreto se apresente fissurada e com nível de tensões elevado, não permitindo assim, assumir o diagrama 
de tensão x deformação linear, os esforços aqui calculados consideram uma análise elástica e linear. Portanto, assume-se que os elementos de concreto tenham capacidade de rotação plástica suficiente para que ocorra a redistribuição dos esforços, tornando-os, no ELU, próximos aos da análise efetuada.

Para a combinação última, os seguintes coeficientes de majoração das ações foram considerados: $\gamma_{\mathrm{p} 1}$ (protensão extradorsal) igual a 1,00 e $\gamma_{\mathrm{p} 2}$ (protensão interna) igual a 0,$90 ; \gamma_{\mathrm{g}}$ (ações permanentes) igual a 1,35 e $\gamma_{\mathrm{q}}$ (ações variáveis) igual a 1,5.

SETRA (2001) recomenda para a segurança ao estado limite último dos cabos que a tensão máxima seja menor ou igual a $75 \%$ da resistência característica do aço.

A tabela 4.15 apresenta as tensões máximas para a combinação última nos cabos extradorsais.

Tabela 4.15 - Tensão máxima nos cabos extradorsais considerando a combinação última das ações.

\begin{tabular}{|c|c|c|c|}
\hline \multirow{2}{*}{ Cabo } & \multicolumn{2}{c|}{$\sigma_{\text {máx }}($ ELU) } \\
\cline { 3 - 4 } & $(\mathrm{MPa})$ & $\% f_{\text {ptk }}$ \\
\hline 1 & 4 & 1279 & 67,3 \\
\hline 2 & 3 & 1306 & 68,7 \\
\hline 5 & 8 & 1281 & 67,4 \\
\hline 6 & 7 & 1301 & 68,4 \\
\hline 9 & 12 & 1282 & 67,5 \\
\hline 10 & 11 & 1293 & 68,1 \\
\hline 13 & 16 & 1282 & 67,5 \\
\hline 14 & 15 & 1285 & 67,6 \\
\hline 17 & 20 & 1278 & 67,3 \\
\hline 18 & 19 & 1272 & 66,9 \\
\hline 21 & 24 & 1275 & 67,1 \\
\hline 22 & 23 & 1255 & 66,1 \\
\hline 25 & 28 & 1270 & 66,8 \\
\hline 26 & 27 & 1234 & 64,9 \\
\hline 29 & 32 & 1266 & 66,6 \\
\hline 30 & 31 & 1212 & 63,8 \\
\hline 33 & 36 & 1262 & 66,4 \\
\hline 34 & 35 & 1191 & 62,7 \\
\hline 37 & 40 & 1257 & 66,2 \\
\hline 38 & 39 & 1172 & 61,7 \\
\hline
\end{tabular}

A partir dos resultados da tabela 4.14, verifica-se a segurança ao estado limite último dos cabos, uma vez que a tensão máxima é igual a $68,7 \%$ de $f_{p t k}$. 
Essa folga de resistência no estado limite último permite que se utilize uma maior tensão admissível dos cabos em serviço. Isto se justifica, pois as recomendações, indicadas no capítulo 2 , da máxima flutuação de tensão nos cabos externos são associadas a tensão máxima de ensaio de $65 \%$ de $f_{\text {ptk }}$. Por tanto, desde que seja satisfeita a segurança ao estado limite último, a tensão máxima, para a combinação rara das ações, pode ser o recomendado em ensaios.

\subsection{MODELOS 5a e 5c COMPARADOS À VIGA CONTÍNUA}

Neste item é conduzida uma análise comparativa dos modelos $5 \mathrm{a}$ e $5 \mathrm{c}$ em relação à uma viga contínua de três vãos com as mesmas características destes modelos, exceto pela ausência de torres e cabos no extradorso.

Esse estudo comparativo tem o intuito de ilustrar a melhoria no comportamento global da estrutura através da redução dos momentos fletores e o controle dos deslocamentos verticais do tabuleiro.

Tabela 4.16 - Alguns esforços solicitantes e flechas imediatas.

\begin{tabular}{|c|c|c|c|c|c|c|c|c|}
\hline \multirow{2}{*}{ Modelo } & \multicolumn{3}{|c}{ Apoio int. } & \multicolumn{3}{c|}{ Meio do vão central } & $a$ & $a$ \\
\cline { 2 - 9 } & $\mathrm{M}_{\text {perm }}$ & $\mathrm{M}_{\mathrm{q}}^{-}$ & $\mathrm{M}_{\text {mín }}$ & $\mathrm{M}_{\text {perm }}$ & $\mathrm{M}_{\mathrm{q}}^{+}$ & $\mathrm{M}_{\text {máx }}$ & $\mathrm{g}$ & $\mathrm{g}+\mathrm{q}$ \\
\cline { 2 - 9 } & $\mathrm{kN} . \mathrm{m}$ & $\mathrm{kN} . \mathrm{m}$ & $\mathrm{kN} . \mathrm{m}$ & $\mathrm{kN} . \mathrm{m}$ & $\mathrm{kN} . \mathrm{m}$ & $\mathrm{kN} . \mathrm{m}$ & $\mathrm{cm}$ & $\mathrm{cm}$ \\
\hline 5a & -88713 & -82792 & -171505 & 21721 & 72016 & 93737 & 4,6 & 20,4 \\
\hline 5c & -166858 & -86576 & -253434 & 87405 & 73928 & 161333 & 17,2 & 33,5 \\
\hline Viga & -592990 & -105564 & -698554 & 439982 & 88412 & 528394 & 87,3 & 107,1 \\
\hline
\end{tabular}

A partir dos dados da tabela 4.16 podemos retirar as seguintes conclusões:

$>$ Os momentos máximos (figura 4.51), em módulo, são reduzidos substancialmente, tanto para compensação total das cargas permanentes, quanto para $80 \%$ da mesma, sendo que na primeira a redução é de $75 \%$ e a segunda é de 64\%;

Embora a protensão do modelo básico tenha sido realizada com o intuito de compensar as cargas permanentes em uma eventual construção por balanços sucessivos, percebe-se que a compensação da flecha devido a tais cargas é quase total, ou seja, $95 \%$; 
A compensação da flecha em virtude das cargas permanentes do modelo $5 c$ é da mesma ordem da redução da protensão $(80 \%)$ e a redução da flecha (incluindo o carregamento variável) é de $80 \%$ e $69 \%$ para os modelos 5a e 5c, respectivamente.

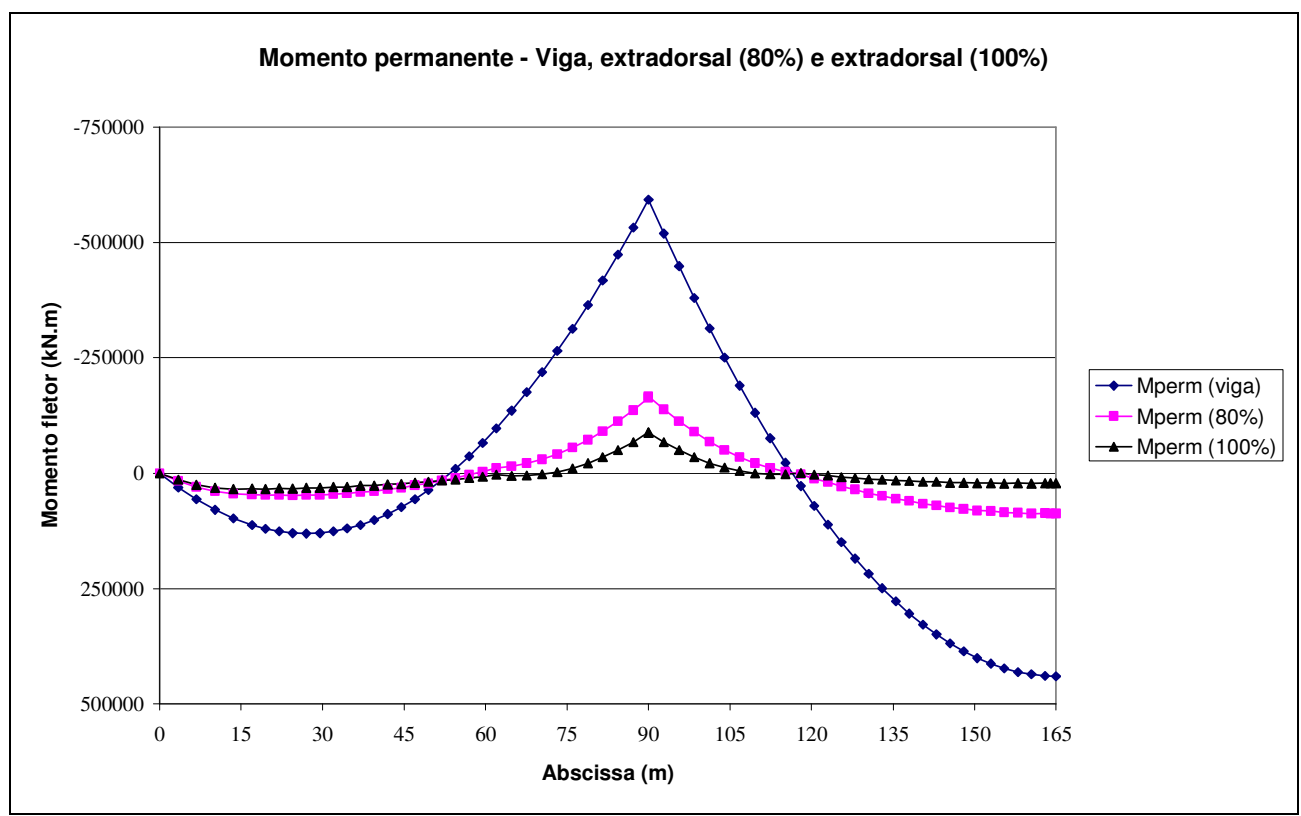

Figura 4.51 - Diagramas de momento fletor devido à carga permanente para os modelos 5a, 5c e para a viga contínua de três vãos.

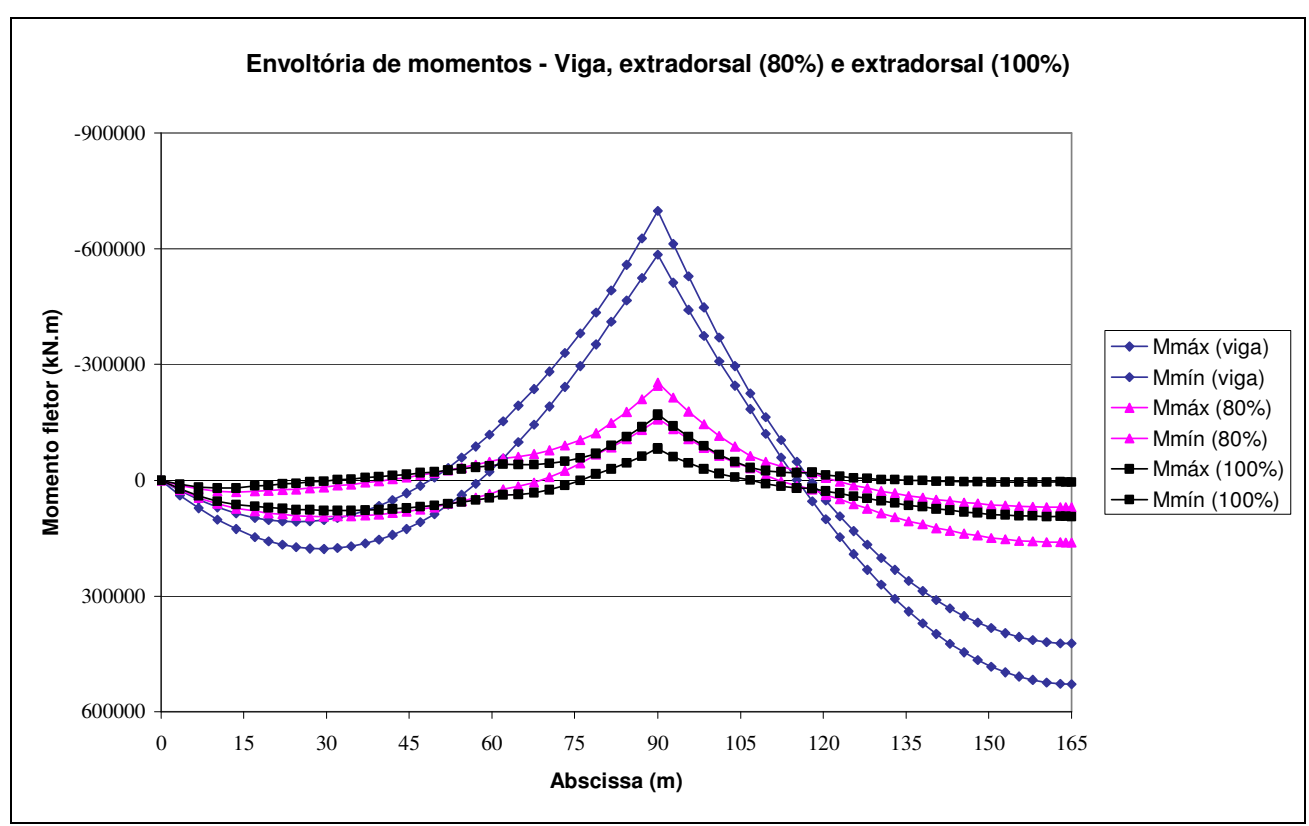

Figura 4.52 - Envoltórias de momento fletor para os modelos 5a, 5c e para a viga contínua de três vãos. 
Ao analisar os momentos máximos e mínimos provocados, apenas, pelas cargas variáveis (figura 4.53), podemos perceber que os diagramas são bastante próximos, o que indica que o comportamento estrutural das pontes com protensão no extradorso, frente às cargas variáveis, se assemelha bastante com o das pontes em viga.

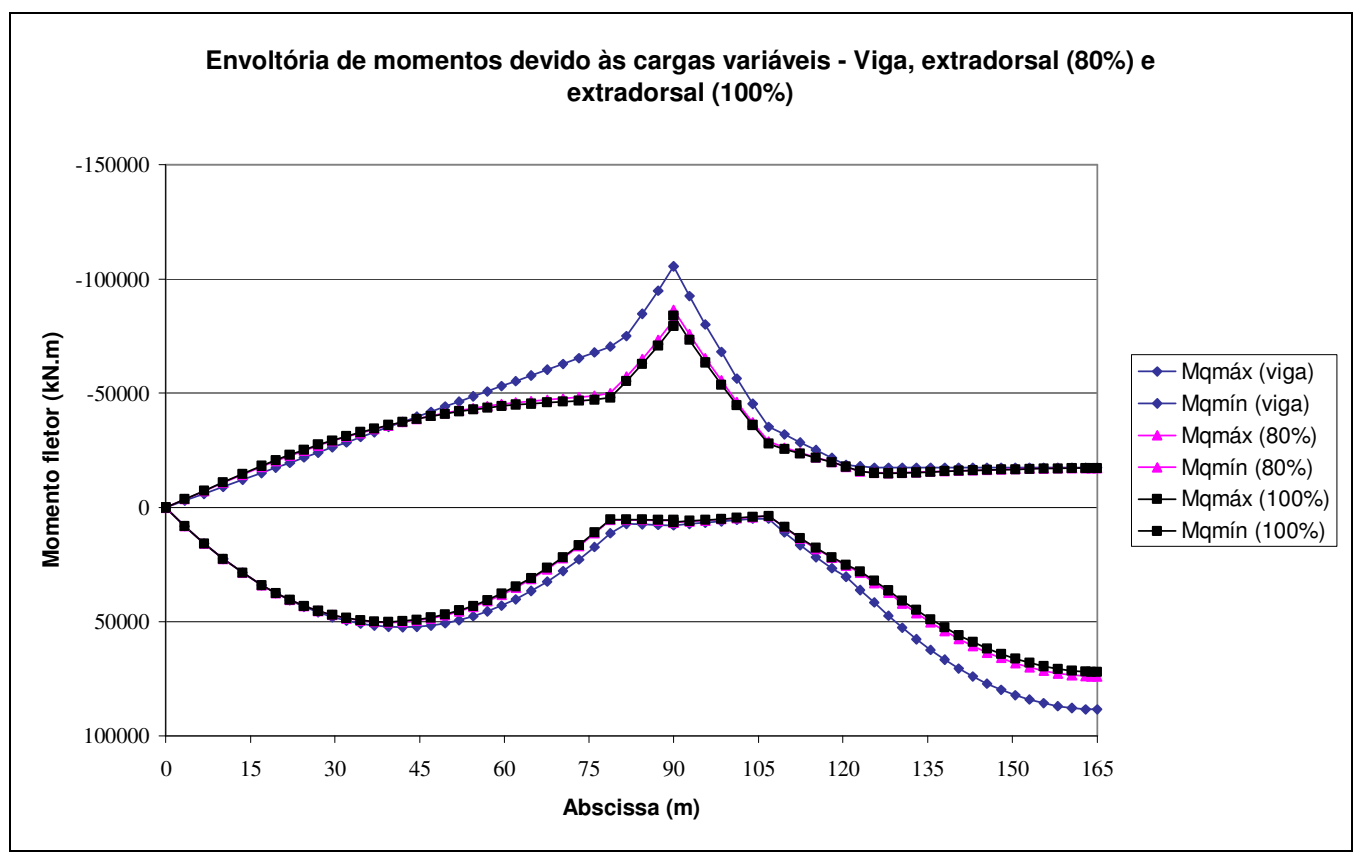

Figura 4.53 - Envoltórias de momento fletor provocados, apenas, pelas cargas variáveis (modelos $5 \mathrm{a}, 5 \mathrm{c}$ e de viga contínua de três vãos).

Esse comportamento frente às cargas variáveis se deve a dois fatos: a grande rigidez da viga e a inexistência de um cabo que controle os deslocamentos horizontais do topo da torre, o que torna a suspensão de tais cargas pouco eficiente.

O sistema de cabos no extradorso reduz os momentos máximos (devido às cargas móveis), em módulo, no apoio intermediário e no vão central. O primeiro é reduzido em $20 \%$ para o modelo 5 a e $18 \%$ para o modelo $5 \mathrm{c}$. No caso do vão central, a redução é de $18 \%$ e $16 \%$ para $100 \%$ e $80 \%$ da compensação de cargas permanentes, respectivamente. 


\subsection{ALGUMAS CONSIDERAÇÕES SOBRE O CÁLCULO DA PROTENSÃO INTERNA E EXTRADORSAL CONDICIONADA AO MÉTODO CONSTRUTIVO}

O método construtivo que melhor se adapta às obras com protensão no extradorso, assim como às estaiadas, é o dos balanços sucessivos e, por isso mesmo, é o que foi utilizado na grande maioria das obras construídas.

O emprego de escoramento geral, além de elevar o custo da construção, cria um problema um tanto delicado de ser resolvido: quantificar os esforços na estrutura, à medida em que os tirantes são protendidos.

Por outro lado, como a análise com a consideração das etapas construtivas de todos os modelos realizados neste trabalho seria bastante trabalhosa, uma vez que tornaria necessária a avaliação da adaptação por fluência, optou-se por realizar uma análise na etapa final da construção, inclusive com as cargas permanentes aplicadas na estrutura em sua fase final.

Inicialmente, para o cálculo da protensão dos cabos no extradorso, buscou-se um critério semelhante ao normalmente aplicado nas pontes estaiadas. Este se baseia em compensar a totalidade das cargas permanentes de tal forma que após a conclusão da estrutura, os pontos de inserção dos estais no tabuleiro estariam com deslocamento vertical nulo.

No entanto, para cabos múltiplos e com espaçamento pequeno, tal critério gera a necessidade de alguns tirantes estarem sujeitos a esforços de compressão. Com isso, estabeleceu-se que a protensão no extradorso seria determinada de forma que ao construir a obra pelo método dos balanços sucessivos, a ponta do balanço estaria com deformação vertical nula e não, necessariamente, os pontos de inserção dos cabos, após a finalização da estrutura.

Embora esse critério seja bom para uma análise comparativa, para a aplicação em projeto é preciso fazer algumas adaptações, em razão de alguns condicionantes gerados pelo método construtivo.

Um condicionante é que ao construir o tabuleiro sem auxílio de escoramento, há a necessidade de protender internamente a viga longitudinal, pelo menos, até que 
o primeiro cabo no extradorso seja instalado. Logo, o critério de determinação da protensão extradorsal deve considerar o efeito de tal ação.

De forma a exemplificar o efeito da protensão interna no cálculo da extradorsal, será analisado um caso simples. Será considerado que, para o modelo básico, os primeiros $23 \mathrm{~m}$ em balanço tenham cablagem negativa com excentricidade constante (figura 4.54) e a protensão seja definida de forma que, para o peso próprio da viga longitudinal, a fibra superior da seção sobre o apoio respeite o estado limite de descompressão.

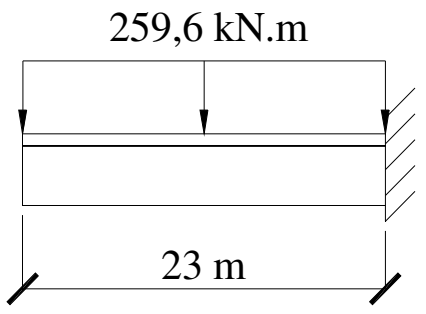

Figura 4.54 - Modelo estrutural simplificado para o cálculo da protensão interna, assumindo a construção pelo método dos balanços sucessivos.

O ELS-D é obedecido se:

$$
P\left(e+\frac{W_{s}}{A}\right)=M_{g}
$$

Logo

$$
P=\frac{68664,2}{1,68+1,50}=21593 \mathrm{kN}
$$

Nota-se que a protensão aqui calculada é bem maior que a do modelo básico e é menor que a do modelo $5 \mathrm{c}$.

Assumindo que a protensão útil é igual a $105 \mathrm{kN}$ (25\% de perdas), a quantidade de cordoalhas de $12,5 \mathrm{~mm}$ é igual a:

$$
n_{1}=\frac{21593}{105} \cong 206 \text { cordoalhas } \Rightarrow 11 \text { cabos de } 19 \phi 12,5 \mathrm{~mm}
$$

A protensão efetiva é igual a: 


$$
P=11 \cdot 19 \cdot 105=21945 k N
$$

A tabela 4.17 mostra a protensão de cada cabo no extradorso levando em conta o efeito desta protensão interna no critério de protensão adotado.

Tabela 4.17 - Protensão extradorsal, considerando a interna no apoio intermediário, em função da construção por balanços sucessivos.

\begin{tabular}{|c|c|c|c|c|c|c|c|c|}
\hline \multirow{2}{*}{ Posição } & \multirow{2}{*}{$\mathrm{L}_{\mathrm{H}}$} & \multirow{2}{*}{$\mathrm{L}_{\mathrm{V}}$} & \multirow{2}{*}{$\mathrm{sen} \alpha$} & \multicolumn{2}{|c|}{ Modelo 5a } & \multicolumn{2}{c|}{$\begin{array}{c}\text { Mod. 5a com protensão } \\
\text { interna }\end{array}$} \\
\cline { 5 - 9 } & & & & $\mathrm{R}_{\mathrm{i}}$ & $\mathrm{P}$ & $\mathrm{R}_{\mathrm{i}}$ & $\mathrm{P}$ & $\mathrm{P}_{5 \mathrm{a}} / \mathrm{P}$ \\
\hline & $\mathrm{M}$ & $\mathrm{m}$ & & $\mathrm{kN}$ & $\mathrm{kN}$ & $\mathrm{kN}$ & $\mathrm{kN}$ & $\%$ \\
\hline 1 & 28 & 13,23 & 0,427 & 3653,10 & 8551,03 & 1741,03 & 4075,33 & 47,7 \\
\hline 2 & 33 & 13,63 & 0,382 & 1613,35 & 4226,20 & 1572,27 & 4118,59 & 97,5 \\
\hline 3 & 38 & 14,03 & 0,346 & 1660,78 & 4794,98 & 1639,99 & 4734,96 & 98,7 \\
\hline 4 & 43 & 14,43 & 0,318 & 1690,62 & 5313,98 & 1679,10 & 5277,78 & 99,3 \\
\hline 5 & 48 & 14,83 & 0,295 & 1711,51 & 5798,00 & 1704,68 & 5774,84 & 99,6 \\
\hline 6 & 53 & 15,23 & 0,276 & 1727,21 & 6253,90 & 1722,93 & 6238,39 & 99,8 \\
\hline 7 & 58 & 15,63 & 0,260 & 1739,58 & 6685,55 & 1736,78 & 6674,78 & 99,8 \\
\hline 8 & 63 & 16,03 & 0,247 & 1749,66 & 7095,50 & 1747,75 & 7087,75 & 99,9 \\
\hline 9 & 68 & 16,43 & 0,235 & 1758,07 & 7485,64 & 1756,74 & 7479,96 & 99,9 \\
\hline 10 & 73 & 16,83 & 0,225 & 1765,23 & 7857,52 & 1764,27 & 7853,25 & 99,9 \\
\hline
\end{tabular}

No caso do modelo básico, esses cabos pré-determinados nos apoios intermediários reduzem a cablagem no vão lateral e central, uma vez que a protensão é maior do que a necessária nesta região, gerando assim, momentos hiperestáticos negativos favoráveis.

Existe, também, a possibilidade de reduzir a armadura ativa nos apoios intermediários com o emprego de escoramento no trecho inicial da construção, que se dá a partir da torre (figura 4.55). Esse escoramento pode ser reutilizado na região dos apoios extremos.

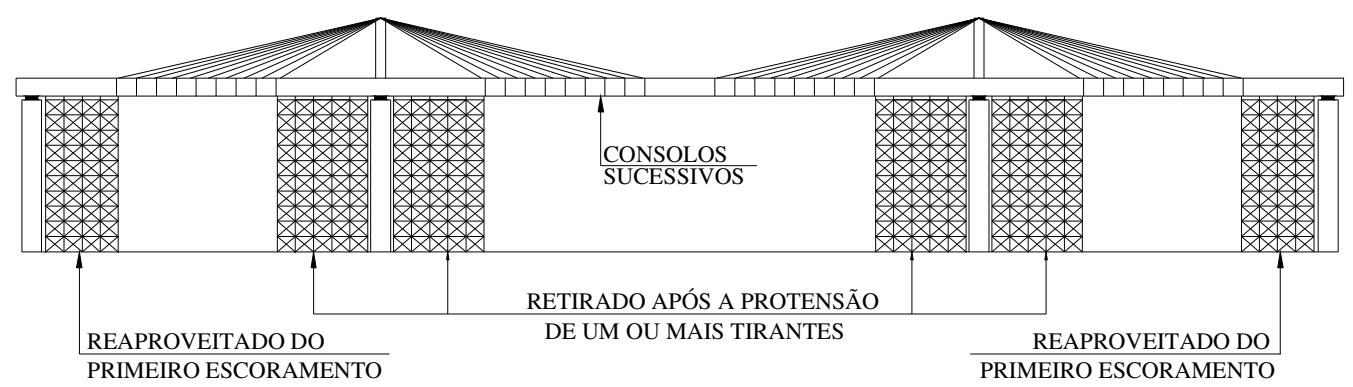

Figura 4.55 - Associação do método dos balanços sucessivos com escoramentos móveis. 


\section{CONCLUSÕES E SUGESTÕES}

\subsection{CONCLUSÕES}

Diante do conteúdo exposto nos capítulos anteriores, pode-se dizer que a ponte com protensão no extradorso é uma solução com bom campo de aplicabilidade.

A quantidade de pontes já construídas ou em construção no curto período de tempo desde a primeira obra, em 1994, é apenas uma amostra do potencial desta tipologia estrutural.

Do trabalho realizado, chegou-se às conclusões expostas a seguir.

\section{Em relação à revisão bibliográfica:}

As pontes de concreto com protensão no extradorso oferecem uma solução econômica para vãos entre 100 e 200 m;

$>$ As pontes com protensão no extradorso, por possuir menor rigidez no sistema de cabos que na viga longitudinal (em respeito às pontes estaiadas), empregam ancoragens (dos cabos no extradorso) comuns a protensão externa convencional;

$>$ De forma a empregar o sistema de protensão similar ao da externa convencional, é preciso que a máxima flutuação de tensão (para a combinação freqüente) não ultrapasse o limite de $50 \mathrm{MPa}$. Esse valor de resistência à fadiga é associado a tensão admissível máxima igual a $65 \%$ da resistência característica do aço de protensão (para a combinação rara). 


\section{Em relação à análise paramétrica ao variar a altura do tabuleiro e a da torre:}

> Ao reduzir a altura do tabuleiro, a área de aço extradorsal necessária diminui e a flutuação de tensão dos cabos e a flecha imediata no tabuleiro aumentam;

Quanto aos esforços máximos no tabuleiro, em módulo, ao reduzir a sua altura, o esfoço normal, os momentos nos vãos lateral e central e no apoio intermediário são reduzidos, em decorrência da redução da carga permanente e do aumento da rigidez do sistema de cabos em relação a viga longitudinal;

$>$ De forma a manter a flutuação máxima dos cabos no extradorso dentro de um valor limite, quanto maior for a altura da torre, maior é a altura mínima do tabuleiro. No caso do limite estabelecido neste trabalho $(\Delta \sigma=$ $50 \mathrm{MPa}$ ) e considerando a compensação total das cargas permanentes, temos: para $\mathrm{H}$ igual a L/15, o limite mínimo de h é, aproximadamente, igual a $\mathrm{L} / 37$, para $\mathrm{H}$ for igual a $\mathrm{L} / 10, \mathrm{~h}_{\text {mín }}$ é, aproximadamente, igual a $\mathrm{L} / 34$;

> No caso da altura da torre igual a L/5, a altura mínima do tabuleiro é, aproximadamente, igual a L/27. Esse valor de h tão alto (para altura de torre comum a ponte estaiada) torna inviável a sua utilização em pontes com protensão no extradorso, pois a redução do custo devido ao uso de ancoragens mais simples não justifica o aumento considerável da altura do tabuleiro e, conseqüentemente, do volume de concreto;

$>$ Ao aumentar a altura da torre, a área de aço extradorsal necessária e a flecha imediata no tabuleiro são reduzidas e a flutuação de tensão máxima dos cabos aumenta;

$>$ Quanto aos esforços máximos no tabuleiro, em módulo, ao aumentar a altura da torre, o esfoço normal, os momentos nos vãos lateral e central e no apoio intermediário são reduzidos;

Quanto maior for a altura da torre e menor a altura do tabuleiro, maior é a rigidez relativa do sistema de cabos e, portanto, o comportamento estrutural do conjunto se assemelha ao das pontes estaiadas. No caso inverso, o comportamento se assemelha ao das pontes em viga contínua; 
$>$ A flutuação de tensão máxima nos cabos e as flechas imediatas no tabuleiro sofrem maior influência ao variar a altura do tabuleiro que a da torre;

$>$ A quantidade de área extradorsal necessária (e a protensão média) não se modifica substancialmente ao variar a altura do tabuleiro, no entanto, é altamente dependente da altura da torre.

\section{Em relação à análise paramétrica ao modificar a tensão admissível do aco}

\section{extradorsal:}

$>$ Ao reduzir a tensão admissível (para a combinação rara) nos cabos de $60 \%$ para $45 \%$ da resistência característica do aço, a área de aço aumenta consideravelmente, aumentando um pouco a rigidez do sistema de cabos;

$>$ Ao reduzir o nível de tensão, assim como no ítem anterior, a flutuação de tensão máxima nos cabos e a flecha imediata diminuem. No entanto, esses parâmetros não se modificam substancialmente;

$>$ A área de aço nos tirantes influe de forma mais significativa o comportamento estrutural das pontes estaiadas que o das pontes com protensão no extradorso;

$>$ Quanto aos esforços solicitantes no tabuleiro, ao reduzir o nível de tensão nos cabos, podemos chegar à mesma conclusão relativa à flutuação de tensão e flecha imediata;

$>$ Embora ao reduzir aquela tensão admissível, o comportamento à fadiga melhore, podemos dizer que essa redução não traz benefícios estruturais significativos, nem benefícios econômicos.

$\underline{\text { Em relação à análise paramétrica ao reduzir o nível de compensação de cargas }}$ permanentes, considerando a altura da torre igual a $\mathrm{L} / 10$ :

Ao reduzir o nível da protensão extradorsal, a área de aço é reduzida e, em compensação, os momentos máximos no tabuleiro, em módulo, aumentam consideravelmente; 
$>$ Ao reduzir o nível de compensação de cargas permanentes (de 100\% para $80 \%$ ), a flutuação de tensão máxima aumenta um pouco, tornando o limite mínimo para a altura do tabuleiro, igual a L/33 (para $\mathrm{H}$ igual a $\mathrm{L} / 10)$;

$>$ Embora o peso de aço de protensão interna aumente consideravelmente, com a redução da compensação das cargas permanentes de $100 \%$ para $80 \%$, o peso total de aço de protensão (interna e extradorsal) ainda é menor neste último.

$\underline{\text { Em relação à análise paramétrica ao variar o comprimento do vão lateral, }}$ considerando a altura da torre igual a L/10 e a altura do tabuleiro igual a L/33:

Ao variar o comprimento do vão lateral, a área de aço extradorsal praticamente não se altera;

$>$ A flutuação de tensão máxima nos cabos extradorsais é reduzida ao diminuir o comprimento do vão lateral, contudo, essa variação não é tão significativa;

$>$ Para vãos muito curtos, menor ou igual a, aproximadamente, $52 \% \mathrm{~L}$, as reações nos apoios extremos são de tração;

$>$ Ao analisar o modelo 5d, que possui cabos de ancoragem, percebe-se que estes não têm a mesma função que os estais de ancoragem. Isso ocorre devido à grande rigidez do tabuleiro das pontes com protensão no extradorso em relação ao das pontes estaiadas.

Em relacão à análise do modelo que possui altura variável no tabuleiro, com valores iguais a $L / 30$, no região da torre, $L / 45$, no trecho central:

$>$ As recomendações de CHO (2000) para as pontes com tabuleiro variável não se mostram adequadas para as pontes com protensão no extradorso, uma vez que a flutuação de tensão máxima ultrapassa o limite estabelecido neste trabalho e recomendado pelo SETRA (2001). 
$\underline{\text { Em relacão à análise da protensão interna, considerando a altura da torre igual }}$ $\underline{\text { a } L / 10, \text { a altura do tabuleiro igual a } \mathrm{L} / 33 \text {, além de dois níveis de compensacão de }}$ cargas permanentes:

A análise das tensões nas fibras extremas da viga longitudinal mostra a necessidade de protender internamente três regiões, um trecho do vão lateral, um trecho próximo ao apoio intermediário e um trecho do vão central;

$>$ A protensão interna reduz a área de aço extradorsal necessária, pois tende a levantar o tabuleiro e, conseqüentemente, reduz as tensões dos cabos no extradorso.

$\underline{\text { Em relação à comparação das pontes com protensão no extradorso com dois }}$ níveis de compensacão de cargas permanentes com uma viga contínua de três vãos:

> Embora a compensação das cargas permanentes tenha sido realizada considerando a ponte construída através de balanços sucessivos, a análise realizada para a obra em sua etapa final mostra que a redução da flecha imediata devido às cargas permanentes é quase total;

$>$ Ao analisar os momentos fletores destes três modelos, em virtude apenas das cargas variáveis, nota-se que, o comportamento da ponte com protensão no extradorso é muito próximo de uma viga contínua;

> A grande vantagem desta ponte em relação àquela com protensão tradiconal é a maior eficiência na compensação das cargas permanentes, melhorando assim o seu comportamento em serviço e, consequentemente, permitindo a redução da altura da seção transversal.

\subsection{SUGESTÕES PARA CRITÉRIOS DE PROJETO}

A partir do trabalho realizado, chega-se às seguintes recomendações para o projeto de uma ponte com protensão no extradorso: 
> Utilização do sistema de protensão externa com ancoragens que permitam a substituição ou ajuste na tensão dos cabos, tomando o cuidado de empregar sistemas de proteção contra corrosão adequados;

> Utilizar a flutuação de tensão máxima igual a $50 \mathrm{MPa}$ para a combinação frequiente das ações, desde que a tensão máxima dos cabos no extradorso não ultrapasse a $65 \%$ da resistência característica do aço;

$>$ A altura da torre igual a L/10, associada à altura do tabuleiro igual a, aproximadamente, L/33. Caso seja adotada altura de torre com valor diferente, deve-se analisar a altura mínima do tabuleiro associada à mesma;

$>$ Adotar o comprimento do vão lateral entre $60 \%$ e $65 \%$ do comprimento do vão central;

$>$ Ao utilizar o método dos balanços sucessivos é preciso analisar com cuidado o grau de compensação das cargas permanentes, de forma a garantir os estados limites durante a construção.

\subsection{SUGESTÕES PARA TRABALHOS FUTUROS}

O conceito de protensão extradorsal é relativamente novo e como toda nova idéia, o conhecimento acerca de seu comportamento estrutural se constrói de forma gradual. Obviamente, o conteúdo deste trabalho não abrangeu a totalidade do estudo sobre as pontes com protensão no extradorso, havendo ainda muitos aspectos a serem examinados. Algumas sugestões são apresentadas:

Analisar parametricamente as pontes com protensão no extradorso com altura de tabuleiro variável;

$>$ Estudar os efeitos de diferentes critérios de protensão;

$>$ Analisar a distância ótima entre a torre e o primeiro cabo extradorsal;

$>$ Aprofudar-se no estudo dos efeitos de fadiga dos cabos pós-tracionados, analisando-os experimentalmente, com o intuito de gerar um diagrama de 
Goodman para os cabos externos com ancoragem que permita a substituição e reprotensão dos cabos;

$>$ Estudar os efeitos devido à retração e à fluência do concreto, de forma a analisar de forma mais realista o comportamento estrutural das pontes com protensão no extradorso ao longo do tempo;

> Estudar o comportamento estrutural da ponte, considerando as etapas de construção, principalmente pelo método dos balanços sucessivos;

$>$ Estudar o efeito da temperatura, principalmente no que diz respeito a sua influência na flutuação de tensão dos cabos extradorsais;

> Analisar o comportamento dinâmico das pontes com protensão no extradorso frente ao tráfego e ao vento. Esse estudo teria a finalidade de quantificar de forma mais realista o limite de fadiga para os cabos extradorsais;

$>$ Fazer um estudo quantitativo e comparativo para diversos vãos das quantidades de materiais que seriam necessários para a construção de três tipos de pontes, as com protensão externa e extradorsal e as estaiadas;

> Realizar um estudo paramétrico das pontes suportadas com cabos externos inferiores, comparando-os com as pontes protendidas no extradorso, analisando as diferenças e verificando se existe, de fato, alguma razão para considerá-las como tipologias estruturais diferentes. 


\section{REFERÊNCIAS BIBLIOGRÁFICAS}

ASSOCIAÇÃO BRASILEIRA DE NORMAS TÉCNICAS (2003). NBR6118 Projeto de estruturas de concreto - Procedimento. Rio de Janeiro. ASSOCIAÇÃO BRASILEIRA DE NORMAS TÉCNICAS (1984). NBR7188 Carga móvel em pontes rodoviárias e passarela de pedestre. Rio de Janeiro. ASSOCIAÇÃO BRASILEIRA DE NORMAS TÉCNICAS (2003). NBR8681 Ações e segurança nas estruturas - Procedimento. Rio de Janeiro.

CAZET, P. (1990). Le viaduc métallique sur l'Oberargen (RFA). Travaux, , v.655, p.9-14. Juil.

CHO, G. C. (2000). Comportamiento estructural y criterios de diseño de los puentes con pretensado extradosado. 137p. Barcelona. Tesis doctoral - Escuela Técnica Superior de Ingenieros de Caminos, Canales y Puertos de Barcelona.

FÉDERATION INTERNATIONALE DU BETON - FIB (2005). Fib bulletin 30 Acceptance of stay cable systems using prestressing steels. Lausanne, Switzerland.

FÉDERATION INTERNATIONALE DE LA PRÉCONTRAINTE - FIP (1993). Recommendations for the acceptance of post-tensioning systems. London.

GIMSING, N. J. (1983). Cable-supported bridges. Chichester: John Wiley, 400p.

ISHII et al. (2005). Pontes extradorso. Congresso de pontes e estruturas da ABPE. Rio de Janeiro.

LEONHARDT, F. (1982). Bridges. Stuttgart, Deutsche Verlags.

LEONHARDT, F. (1983). Construções de concreto: concreto protendido. Rio de Janeiro, Interciência, v.5.

MANTEROLA, J. (1997). El estado del arte del pretensado. Conferencia pronunciada en la sesión de apertura de la $\mathrm{XV}^{\mathrm{a}}$ Asamblea Técnica Nacional de la ATEP. Hormigón y Acero, Madrid, $2^{\circ}$ trimestre, p.9-28. 
MATHIVAT, J. (1980). Construcción de puentes de hormigón pretensado por voladizos sucesivos. Barcelona, Editores Técnicos Asociados, S. A. 401p.

MATHIVAT, J. (1988). Recent developments in prestressed concrete bridges. FIP notes, 1988/2, p. 15-21. Federation International de la Précontrainte, London.

MENN, C. (1990). Prestressed concrete bridges. Berlim, Birkhäuser Verlag.

OGAWA, A.; MATSUDA, T. (1998). The Tsukuhara extradosed bridge near Kobe. Structural Engineering International, v.8, n.3, p.72-73.

PODOLNY, W.; SCALZI, J. B. (1976). Construction and design of cable-stayed bridges. New York, John Wiley. 506p.

POST-TENSIONING INSTITUTE - PTI (2000). Recommendations for stay cable design, testing and installation. Phoenix, Arizona.

REIS, A.; PEREIRA, A. (1994). Socorridos Bridge: a cable-panel stayed concept. In: PROCEEDINGS OF THE INTERNATIONAL CONFERENCE ON CABLESTAYED AND SUSPENSION BRIDGES, Deauville, France. Proceedings. Association Française Pour la Construcion. v.1. p.351-360.

RYALS, K. et al. (1993) Fretting fatigue of external tendons in segmental bridge deviator. In: INTERNATIONAL WORKSHOP ON BEHAVIOR OF EXTERNAL PRESTRESSING IN STRUCTURES, St. Rémy-lès-Chevreuse, France. Proceedings. Association Française Pour la Construcion. p.131-140.

SERVICE D'ÉTUDE TECHNIQUES DES ROUTES ET AUTOROUTES - SETRA (2001). Haubans - Recommandations de la commission interministérielle de la précontraine. Bagneux, France.

TORNERI, P. (2002). Comportamento estrutural de pontes estaiadas: comparação de alternativas. São Paulo. 272p. Dissertação de mestrado - Escola Politécnica da Universidade de São Paulo.

VIRLOGEUX, M. (1994). Fatigue in cable-stayed bridges. XII Congress de la FIP, Washington. P.181-217.

VIRLOGEUX, M. (1999). Recent evolution of cable-stayed bridges. Engineering Structures, Oxford, v.21, n.8, p.737-755, Aug.

VIRLOGEUX, M. (2001). Bridges with multiple cable-stayed spans. Structural Engineering International, v.11, n.1, p.61-82, Feb. 
VIRLOGEUX, M. et al. (1994). A prestressed concrete slab suspended from below: the Truc de la Fare bridge. XII Congress de la FIP, Washington. P.403-417.

WALTHER, R. et al. (1999). Cable stayed bridges. 2.ed. London, Thomas Telford Ltd. 225p.

WITTFOHT, H. (1984). Building bridges: history, technology, construction. Düsseldorf: Beton-Verlag, 327p.

WOLLMANN, P. et al. (1996). Fretting fatigue in post-tensioned concrete beams. ACI Structural Journal, v.93, n.2, p.172-179. March-April. 


\section{BIBLIOGRAFIA COMPLEMENTAR}

FIGI, H. et al. (1997). Sunninberg bridge, Klosters, Switzaerland. Structural Engineering International, v.7, n.1, p.6-8, Feb.

GRISON, A; TONELlO, J. (1997). A 43 - Pont de Saint-Rémy-de-Maurienne (Savoie). Un parti original: la précontrainte extradossée. Travaux, n.733, p.16-19. Juil-août.

HONIGMANN, C.; BILlnGTON, D. P. (2003). Conceptual design for the Sunninberg bridge. Journal of Bridge Engineering, v.8, n.3, p.122-130. may-jun.

IKEDA, H. et al. (2002). PC - steel composite, continuous and extradosed bridges: Kiso and Ibi River bridges. In: THE FIRST FIB CONGRESS, Osaka, Japan. Japan Prestressed Concrete Engineering Association. p.137-140.

INTERNATIONAL CONFERENCE ON CABLE-STAYED AND SUSPENSION BRIDGES (1994), Deauville, France. Deauville, France. Proceedings. Association Française Pour la Construcion. v.1.

KIMISHIMA, M.; MAEDA, H.; YAMAZAKI, K. (2002). Extradosed prestressed concrete bridge in the Philippines: Second Mandaue-Mactan bridge. In: THE FIRST FIB CONGRESS, Osaka, Japan. Japan Prestressed Concrete Engineering Association. p.145-148.

LlOMBART, J. A.; REVOLTÓS, J. (2004). Punte extradosado sobre el río Deba (autopista Vitoria-Gasteiz-Eibar). Hormigón y Acero, Madrid, $1^{\circ}$ trimestre. p.5-19.

OSHIMA, H. et al. (2002). 3-span hybrid extra-dosed bridge: Japan Palau friendship bridge. In: THE FIRST FIB CONGRESS, Osaka, Japan. Japan Prestressed Concrete Engineering Association. p.141-144.

SASAKI, H.; IKEDA, T.; ICHINOMIYA, T. (2002). Prestressed concrete extradosed bridge: Shikari-Ohashi bridge. In: THE FIRST FIB CONGRESS, Osaka, Japan. Japan Prestressed Concrete Engineering Association. p.149-152. 
VIRLOGEUX, M. (1993). External prestressing: historical and modern applications. In: INTERNATIONAL WORKSHOP ON BEHAVIOR OF EXTERNAL PRESTRESSING IN STRUCTURES, St. Rémy-lès-Chevreuse, France. Proceedings. Association Française Pour la Construcion. p.13-41. 


\section{ANEXO I: PROTENSÃO, ÁREA, PESO E TENSÕES DOS CABOS NO EXTRADORSO DOS 21 MODELOS ANALISADOS}

Este anexo tem por objetivo apresentar de forma mais detalhada a protensão, a área, o peso e as tensões máximas e mínimas (além da flutuação de tensão) dos cabos no extradorso. Os resultados são exibidos nas tabelas a seguir.

Tabela I.1 - Resultados do modelo 1.

\begin{tabular}{|c|c|c|c|c|c|c|c|}
\hline \multirow{2}{*}{\multicolumn{2}{|c|}{ Cabo }} & $\mathrm{P}$ & Ap & Peso & $\sigma_{\text {máx }}$ & $\sigma_{\operatorname{mín}}$ & $\Delta \sigma$ \\
\hline & & $(\mathrm{kN})$ & $\left(\mathrm{cm}^{2}\right)$ & (Ton) & (MPa) & $(\mathrm{MPa})$ & (MPa) \\
\hline 1 & 4 & \multirow{2}{*}{11906,91} & \multirow{2}{*}{115,38} & \multirow{2}{*}{2,627} & 1131 & 1033 & 49 \\
\hline 2 & 3 & & & & 1139 & 1029 & 55 \\
\hline 5 & 8 & \multirow{2}{*}{5737,21} & \multirow{2}{*}{55,22} & \multirow{2}{*}{1,472} & 1135 & 1036 & 50 \\
\hline 6 & 7 & & & & 1140 & 1033 & 54 \\
\hline 9 & 12 & \multirow{2}{*}{6452,14} & \multirow{2}{*}{61,68} & \multirow{2}{*}{1,884} & 1136 & 1038 & 49 \\
\hline 10 & 11 & & & & 1139 & 1036 & 52 \\
\hline 13 & 16 & \multirow{2}{*}{7074,30} & \multirow{2}{*}{67,18} & \multirow{2}{*}{2,315} & 1139 & 1042 & 49 \\
\hline 14 & 15 & & & & 1139 & 1042 & 49 \\
\hline 17 & 20 & \multirow{2}{*}{7630,38} & \multirow{2}{*}{72,12} & \multirow{2}{*}{2,767} & 1140 & 1044 & 48 \\
\hline 18 & 19 & & & & 1137 & 1046 & 46 \\
\hline 21 & 24 & \multirow{2}{*}{8134,49} & \multirow{2}{*}{76,81} & \multirow{2}{*}{3,248} & 1139 & 1036 & 52 \\
\hline 22 & 23 & & & & 1129 & 1044 & 43 \\
\hline 25 & 28 & \multirow{2}{*}{8595,46} & \multirow{2}{*}{81,40} & \multirow{2}{*}{3,760} & 1140 & 1024 & 58 \\
\hline 26 & 27 & & & & 1118 & 1041 & 39 \\
\hline 29 & 32 & \multirow{2}{*}{9019,50} & \multirow{2}{*}{85,57} & \multirow{2}{*}{4,289} & 1140 & 1011 & 65 \\
\hline 30 & 31 & & & & 1108 & 1038 & 35 \\
\hline 33 & 36 & \multirow{2}{*}{9411,34} & \multirow{2}{*}{89,38} & \multirow{2}{*}{4,830} & 1140 & 999 & 71 \\
\hline 34 & 35 & & & & 1097 & 1035 & 31 \\
\hline 37 & 40 & \multirow{2}{*}{9774,76} & \multirow{2}{*}{93,00} & \multirow{2}{*}{5,392} & 1140 & 988 & 76 \\
\hline 38 & 39 & & & & 1091 & 1028 & 32 \\
\hline
\end{tabular}


Tabela I.2 - Resultados do modelo 2.

\begin{tabular}{|c|c|c|c|c|c|c|c|}
\hline \multirow{2}{*}{\multicolumn{2}{|c|}{ Cabo }} & $\mathrm{P}$ & Ap & Peso & $\sigma_{\text {máx }}$ & $\sigma_{\text {mín }}$ & $\Delta \sigma$ \\
\hline & & $(\mathrm{kN})$ & $\left(\mathrm{cm}^{2}\right)$ & (Ton) & (MPa) & (MPa) & $(\mathrm{MPa})$ \\
\hline 1 & 4 & \multirow{2}{*}{12954,28} & \multirow{2}{*}{117,02} & \multirow{2}{*}{2,681} & 1136 & 1087 & 25 \\
\hline 2 & 3 & & & & 1140 & 1085 & 28 \\
\hline 5 & 8 & \multirow{2}{*}{6376,72} & \multirow{2}{*}{57,40} & \multirow{2}{*}{1,537} & 1139 & 1089 & 25 \\
\hline 6 & 7 & & & & 1141 & 1088 & 27 \\
\hline 9 & 12 & \multirow{2}{*}{7183,49} & \multirow{2}{*}{64,54} & \multirow{2}{*}{1,979} & 1139 & 1089 & 25 \\
\hline 10 & 11 & & & & 1139 & 1089 & 25 \\
\hline 13 & 16 & \multirow{2}{*}{7892,27} & \multirow{2}{*}{70,72} & \multirow{2}{*}{2,444} & 1139 & 1090 & 25 \\
\hline 14 & 15 & & & & 1138 & 1090 & 24 \\
\hline 17 & 20 & \multirow{2}{*}{8530,79} & \multirow{2}{*}{76,24} & \multirow{2}{*}{2,932} & 1140 & 1092 & 24 \\
\hline 18 & 19 & & & & 1138 & 1093 & 23 \\
\hline 21 & 24 & \multirow{2}{*}{9113,58} & \multirow{2}{*}{81,44} & \multirow{2}{*}{3,451} & 1141 & 1088 & 27 \\
\hline 22 & 23 & & & & 1134 & 1093 & 21 \\
\hline 25 & 28 & \multirow{2}{*}{9649,70} & \multirow{2}{*}{86,39} & \multirow{2}{*}{3,999} & 1141 & 1082 & 30 \\
\hline 26 & 27 & & & & 1128 & 1091 & 19 \\
\hline 29 & 32 & \multirow{2}{*}{10145,53} & \multirow{2}{*}{90,99} & \multirow{2}{*}{4,568} & 1140 & 1077 & 32 \\
\hline 30 & 31 & & & & 1123 & 1089 & 17 \\
\hline 33 & 36 & \multirow{2}{*}{10605,96} & \multirow{2}{*}{95,21} & \multirow{2}{*}{5,153} & 1140 & 1071 & 35 \\
\hline 34 & 35 & & & & 1117 & 1087 & 15 \\
\hline 37 & 40 & \multirow{2}{*}{11034,90} & \multirow{2}{*}{99,15} & \multirow{2}{*}{5,756} & 1141 & 1068 & 37 \\
\hline 38 & 39 & & & & 1115 & 1086 & 15 \\
\hline
\end{tabular}

Tabela I.3 - Resultados do modelo 3.

\begin{tabular}{|c|c|c|c|c|c|c|c|}
\hline \multirow{2}{*}{\multicolumn{2}{|c|}{ Cabo }} & $\mathrm{P}$ & Ap & Peso & $\sigma_{\text {máx }}$ & $\sigma_{\text {mín }}$ & $\Delta \sigma$ \\
\hline & & $(\mathrm{kN})$ & $\left(\mathrm{cm}^{2}\right)$ & (Ton) & (MPa) & (MPa) & $(\mathrm{MPa})$ \\
\hline 1 & 4 & \multirow{2}{*}{13912,70} & \multirow{2}{*}{122,36} & \multirow{2}{*}{2,821} & 1136 & 1108 & 14 \\
\hline 2 & 3 & & & & 1139 & 1107 & 16 \\
\hline 5 & 8 & \multirow{2}{*}{6934,56} & \multirow{2}{*}{60,88} & \multirow{2}{*}{1,638} & 1138 & 1109 & 15 \\
\hline 6 & 7 & & & & 1139 & 1108 & 16 \\
\hline 9 & 12 & \multirow{2}{*}{7823,41} & \multirow{2}{*}{68,63} & \multirow{2}{*}{2,112} & 1139 & 1110 & 15 \\
\hline 10 & 11 & & & & 1139 & 1110 & 15 \\
\hline 13 & 16 & \multirow{2}{*}{8610,19} & \multirow{2}{*}{75,53} & \multirow{2}{*}{2,618} & 1138 & 1110 & 14 \\
\hline 14 & 15 & & & & 1137 & 1110 & 14 \\
\hline 17 & 20 & \multirow{2}{*}{9323,54} & \multirow{2}{*}{81,79} & \multirow{2}{*}{3,154} & 1138 & 1109 & 15 \\
\hline 18 & 19 & & & & 1136 & 1110 & 13 \\
\hline 21 & 24 & \multirow{2}{*}{9978,28} & \multirow{2}{*}{87,53} & \multirow{2}{*}{3,717} & 1138 & 1108 & 15 \\
\hline 22 & 23 & & & & 1134 & 1110 & 12 \\
\hline 25 & 28 & \multirow{2}{*}{10583,62} & \multirow{2}{*}{92,84} & \multirow{2}{*}{4,306} & 1139 & 1106 & 17 \\
\hline 26 & 27 & & & & 1132 & 1111 & 11 \\
\hline 29 & 32 & \multirow{2}{*}{11146,01} & \multirow{2}{*}{97,77} & \multirow{2}{*}{4,917} & 1140 & 1105 & 18 \\
\hline 30 & 31 & & & & 1130 & 1111 & 10 \\
\hline 33 & 36 & \multirow{2}{*}{11670,41} & \multirow{2}{*}{102,55} & \multirow{2}{*}{5,560} & 1140 & 1101 & 20 \\
\hline 34 & 35 & & & & 1127 & 1110 & 9 \\
\hline 37 & 40 & \multirow{2}{*}{12160,83} & \multirow{2}{*}{106,86} & \multirow{2}{*}{6,212} & 1141 & 1100 & 21 \\
\hline 38 & 39 & & & & 1126 & 1100 & 13 \\
\hline
\end{tabular}


Tabela I.4 - Resultados do modelo 4a.

\begin{tabular}{|c|c|c|c|c|c|c|c|}
\hline \multirow{2}{*}{\multicolumn{2}{|c|}{ Cabo }} & $\mathrm{P}$ & Ap & Peso & $\sigma_{\text {máx }}$ & $\sigma_{\text {mín }}$ & $\Delta \sigma$ \\
\hline & & $(\mathrm{kN})$ & $\left(\mathrm{cm}^{2}\right)$ & (Ton) & (MPa) & (MPa) & $(\mathrm{MPa})$ \\
\hline 1 & 4 & \multirow{2}{*}{7592,00} & \multirow{2}{*}{78,11} & \multirow{2}{*}{1,882} & 1130 & 1006 & 62 \\
\hline 2 & 3 & & & & 1140 & 996 & 72 \\
\hline 5 & 8 & \multirow{2}{*}{3684,05} & \multirow{2}{*}{37,63} & \multirow{2}{*}{1,048} & 1132 & 1006 & 63 \\
\hline 6 & 7 & & & & 1139 & 998 & 71 \\
\hline 9 & 12 & \multirow{2}{*}{4183,69} & \multirow{2}{*}{42,30} & \multirow{2}{*}{1,338} & 1135 & 1009 & 63 \\
\hline 10 & 11 & & & & 1139 & 1004 & 68 \\
\hline 13 & 16 & \multirow{2}{*}{4637,54} & \multirow{2}{*}{46,38} & \multirow{2}{*}{1,644} & 1138 & 1013 & 63 \\
\hline 14 & 15 & & & & 1140 & 1011 & 65 \\
\hline 17 & 20 & \multirow{2}{*}{5059,19} & \multirow{2}{*}{50,04} & \multirow{2}{*}{1,966} & 1139 & 1016 & 62 \\
\hline 18 & 19 & & & & 1138 & 1018 & 60 \\
\hline 21 & 24 & \multirow{2}{*}{5455,04} & \multirow{2}{*}{53,59} & \multirow{2}{*}{2,312} & 1140 & 1016 & 62 \\
\hline 22 & 23 & & & & 1134 & 1022 & 56 \\
\hline 25 & 28 & \multirow{2}{*}{5828,74} & \multirow{2}{*}{57,43} & \multirow{2}{*}{2,700} & 1139 & 997 & 71 \\
\hline 26 & 27 & & & & 1119 & 1018 & 51 \\
\hline 29 & 32 & \multirow{2}{*}{6182,70} & \multirow{2}{*}{60,91} & \multirow{2}{*}{3,101} & 1140 & 981 & 80 \\
\hline 30 & 31 & & & & 1107 & 1015 & 46 \\
\hline 33 & 36 & \multirow{2}{*}{6518,73} & \multirow{2}{*}{64,22} & \multirow{2}{*}{3,519} & 1141 & 966 & 88 \\
\hline 34 & 35 & & & & 1094 & 1014 & 40 \\
\hline 37 & 40 & \multirow{2}{*}{6838,31} & \multirow{2}{*}{67,37} & \multirow{2}{*}{3,954} & 1141 & 951 & 95 \\
\hline 38 & 39 & & & & 1087 & 1007 & 40 \\
\hline
\end{tabular}

Tabela I.5 - Resultados do modelo 4b

\begin{tabular}{|c|c|c|c|c|c|c|c|}
\hline \multirow{2}{*}{\multicolumn{2}{|c|}{ Cabo }} & $\mathrm{P}$ & Ap & Peso & $\sigma_{\text {máx }}$ & $\sigma_{\text {mín }}$ & $\Delta \sigma$ \\
\hline & & $(\mathrm{kN})$ & $\left(\mathrm{cm}^{2}\right)$ & (Ton) & (MPa) & (MPa) & $(\mathrm{MPa})$ \\
\hline 1 & 4 & \multirow{2}{*}{7592,00} & \multirow{2}{*}{107,38} & \multirow{2}{*}{2,588} & 847 & 742 & 53 \\
\hline 2 & 3 & & & & 856 & 730 & 63 \\
\hline 5 & 8 & \multirow{2}{*}{3684,05} & \multirow{2}{*}{51,67} & \multirow{2}{*}{1,438} & 848 & 740 & 54 \\
\hline 6 & 7 & & & & 855 & 731 & 62 \\
\hline 9 & 12 & \multirow{2}{*}{4183,69} & \multirow{2}{*}{57,87} & \multirow{2}{*}{1,830} & 851 & 742 & 55 \\
\hline 10 & 11 & & & & 855 & 736 & 60 \\
\hline 13 & 16 & \multirow{2}{*}{4637,54} & \multirow{2}{*}{63,27} & \multirow{2}{*}{2,243} & 853 & 745 & 54 \\
\hline 14 & 15 & & & & 856 & 742 & 57 \\
\hline 17 & 20 & \multirow{2}{*}{5059,19} & \multirow{2}{*}{68,18} & \multirow{2}{*}{2,679} & 855 & 748 & 54 \\
\hline 18 & 19 & & & & 855 & 748 & 54 \\
\hline 21 & 24 & \multirow{2}{*}{5455,04} & \multirow{2}{*}{72,73} & \multirow{2}{*}{3,139} & 855 & 750 & 53 \\
\hline 22 & 23 & & & & 852 & 753 & 50 \\
\hline 25 & 28 & \multirow{2}{*}{5828,74} & \multirow{2}{*}{77,82} & \multirow{2}{*}{3,659} & 854 & 733 & 61 \\
\hline 26 & 27 & & & & 840 & 749 & 46 \\
\hline 29 & 32 & \multirow{2}{*}{6182,70} & \multirow{2}{*}{82,66} & \multirow{2}{*}{4,208} & 855 & 717 & 69 \\
\hline 30 & 31 & & & & 829 & 747 & 41 \\
\hline 33 & 36 & \multirow{2}{*}{6518,73} & \multirow{2}{*}{87,27} & \multirow{2}{*}{4,782} & 855 & 700 & 78 \\
\hline 34 & 35 & & & & 816 & 743 & 37 \\
\hline 37 & 40 & \multirow{2}{*}{6838,31} & \multirow{2}{*}{91,79} & \multirow{2}{*}{5,388} & 854 & 684 & 85 \\
\hline 38 & 39 & & & & 807 & 735 & 36 \\
\hline
\end{tabular}


Tabela I.6 - Resultados do modelo 5a.

\begin{tabular}{|c|c|c|c|c|c|c|c|}
\hline \multirow{2}{*}{\multicolumn{2}{|c|}{ Cabo }} & $\mathrm{P}$ & Ap & Peso & $\sigma_{\text {máx }}$ & $\sigma_{\text {mín }}$ & $\Delta \sigma$ \\
\hline & & $(\mathrm{kN})$ & $\left(\mathrm{cm}^{2}\right)$ & (Ton) & (MPa) & (MPa) & (MPa) \\
\hline 1 & 4 & \multirow{2}{*}{8551,03} & \multirow{2}{*}{80,37} & \multirow{2}{*}{1,954} & 1134 & 1070 & 32 \\
\hline 2 & 3 & & & & 1141 & 1066 & 38 \\
\hline 5 & 8 & \multirow{2}{*}{4226,20} & \multirow{2}{*}{39,57} & \multirow{2}{*}{1,109} & 1136 & 1070 & 33 \\
\hline 6 & 7 & & & & 1141 & 1068 & 37 \\
\hline 9 & 12 & \multirow{2}{*}{4794,98} & \multirow{2}{*}{44,65} & \multirow{2}{*}{1,420} & 1139 & 1073 & 33 \\
\hline 10 & 11 & & & & 1141 & 1071 & 35 \\
\hline 13 & 16 & \multirow{2}{*}{5313,98} & \multirow{2}{*}{49,25} & \multirow{2}{*}{1,754} & 1139 & 1074 & 33 \\
\hline 14 & 15 & & & & 1139 & 1073 & 33 \\
\hline 17 & 20 & \multirow{2}{*}{5798,00} & \multirow{2}{*}{53,54} & \multirow{2}{*}{2,111} & 1139 & 1075 & 32 \\
\hline 18 & 19 & & & & 1137 & 1076 & 31 \\
\hline 21 & 24 & \multirow{2}{*}{6253,90} & \multirow{2}{*}{57,64} & \multirow{2}{*}{2,495} & 1139 & 1072 & 34 \\
\hline 22 & 23 & & & & 1133 & 1076 & 29 \\
\hline 25 & 28 & \multirow{2}{*}{6685,55} & \multirow{2}{*}{61,62} & \multirow{2}{*}{2,906} & 1139 & 1065 & 37 \\
\hline 26 & 27 & & & & 1126 & 1075 & 26 \\
\hline 29 & 32 & \multirow{2}{*}{7095,50} & \multirow{2}{*}{65,34} & \multirow{2}{*}{3,334} & 1141 & 1060 & 41 \\
\hline 30 & 31 & & & & 1122 & 1076 & 23 \\
\hline 33 & 36 & \multirow{2}{*}{7485,64} & \multirow{2}{*}{68,93} & \multirow{2}{*}{3,785} & 1141 & 1053 & 44 \\
\hline 34 & 35 & & & & 1115 & 1075 & 20 \\
\hline 37 & 40 & \multirow{2}{*}{7857,52} & \multirow{2}{*}{72,35} & \multirow{2}{*}{4,255} & 1141 & 1048 & 47 \\
\hline 38 & 39 & & & & 1110 & 1073 & 19 \\
\hline
\end{tabular}

Tabela I.7 - Resultados do modelo 5b.

\begin{tabular}{|c|c|c|c|c|c|c|c|}
\hline \multirow{2}{*}{\multicolumn{2}{|c|}{ Cabo }} & $\mathrm{P}$ & Ap & Peso & $\sigma_{\text {máx }}$ & $\sigma_{\text {mín }}$ & $\Delta \sigma$ \\
\hline & & $(\mathrm{kN})$ & $\left(\mathrm{cm}^{2}\right)$ & (Ton) & (MPa) & (MPa) & (MPa) \\
\hline 1 & 4 & \multirow{2}{*}{8551,03} & \multirow{2}{*}{109,07} & \multirow{2}{*}{2,651} & 848 & 789 & 30 \\
\hline 2 & 3 & & & & 855 & 785 & 35 \\
\hline 5 & 8 & \multirow{2}{*}{4226,20} & \multirow{2}{*}{53,70} & \multirow{2}{*}{1,505} & 850 & 790 & 30 \\
\hline 6 & 7 & & & & 855 & 787 & 34 \\
\hline 9 & 12 & \multirow{2}{*}{4794,98} & \multirow{2}{*}{60,54} & \multirow{2}{*}{1,925} & 851 & 791 & 30 \\
\hline 10 & 11 & & & & 854 & 789 & 33 \\
\hline 13 & 16 & \multirow{2}{*}{5313,98} & \multirow{2}{*}{66,51} & \multirow{2}{*}{2,368} & 855 & 796 & 30 \\
\hline 14 & 15 & & & & 856 & 795 & 31 \\
\hline 17 & 20 & \multirow{2}{*}{5798,00} & \multirow{2}{*}{72,11} & \multirow{2}{*}{2,844} & 855 & 797 & 29 \\
\hline 18 & 19 & & & & 854 & 797 & 29 \\
\hline 21 & 24 & \multirow{2}{*}{6253,90} & \multirow{2}{*}{77,50} & \multirow{2}{*}{3,355} & 856 & 797 & 30 \\
\hline 22 & 23 & & & & 852 & 799 & 27 \\
\hline 25 & 28 & \multirow{2}{*}{6685,55} & \multirow{2}{*}{82,84} & \multirow{2}{*}{3,906} & 856 & 790 & 33 \\
\hline 26 & 27 & & & & 846 & 798 & 24 \\
\hline 29 & 32 & \multirow{2}{*}{7095,50} & \multirow{2}{*}{88,14} & \multirow{2}{*}{4,498} & 855 & 781 & 37 \\
\hline 30 & 31 & & & & 838 & 795 & 22 \\
\hline 33 & 36 & \multirow{2}{*}{7485,64} & \multirow{2}{*}{93,99} & \multirow{2}{*}{5,107} & 855 & 775 & 40 \\
\hline 34 & 35 & & & & 832 & 794 & 19 \\
\hline 37 & 40 & \multirow{2}{*}{7857,52} & \multirow{2}{*}{97,61} & \multirow{2}{*}{5,740} & 855 & 769 & 43 \\
\hline 38 & 39 & & & & 827 & 793 & 17 \\
\hline
\end{tabular}


Tabela I.8 - Resultados do modelo 5c.

\begin{tabular}{|c|c|c|c|c|c|c|c|}
\hline \multirow{2}{*}{\multicolumn{2}{|c|}{ Cabo }} & $\mathrm{P}$ & Ap & Peso & $\sigma_{\text {máx }}$ & $\sigma_{\text {mín }}$ & $\Delta \sigma$ \\
\hline & & $(\mathrm{kN})$ & $\left(\mathrm{cm}^{2}\right)$ & (Ton) & (MPa) & (MPa) & (MPa) \\
\hline 1 & 4 & \multirow{2}{*}{8551,03} & \multirow{2}{*}{69,38} & \multirow{2}{*}{1,687} & 1126 & 1058 & 34 \\
\hline 2 & 3 & & & & 1140 & 1063 & 39 \\
\hline 5 & 8 & \multirow{2}{*}{4226,20} & \multirow{2}{*}{34,08} & \multirow{2}{*}{0,955} & 1131 & 1062 & 35 \\
\hline 6 & 7 & & & & 1140 & 1065 & 38 \\
\hline 9 & 12 & \multirow{2}{*}{4794,98} & \multirow{2}{*}{38,32} & \multirow{2}{*}{1,219} & 1135 & 1066 & 35 \\
\hline 10 & 11 & & & & 1139 & 1067 & 36 \\
\hline 13 & 16 & \multirow{2}{*}{5313,98} & \multirow{2}{*}{42,09} & \multirow{2}{*}{1,499} & 1139 & 1071 & 34 \\
\hline 14 & 15 & & & & 1139 & 1071 & 34 \\
\hline 17 & 20 & \multirow{2}{*}{5798,00} & \multirow{2}{*}{45,70} & \multirow{2}{*}{1,802} & 1139 & 1072 & 34 \\
\hline 18 & 19 & & & & 1133 & 1070 & 32 \\
\hline 21 & 24 & \multirow{2}{*}{6253,90} & \multirow{2}{*}{49,10} & \multirow{2}{*}{2,125} & 1139 & 1068 & 36 \\
\hline 22 & 23 & & & & 1126 & 1068 & 29 \\
\hline 25 & 28 & \multirow{2}{*}{6685,55} & \multirow{2}{*}{52,38} & \multirow{2}{*}{2,470} & 1139 & 1060 & 40 \\
\hline 26 & 27 & & & & 1115 & 1063 & 26 \\
\hline 29 & 32 & \multirow{2}{*}{7095,50} & \multirow{2}{*}{55,43} & \multirow{2}{*}{2,829} & 1139 & 1053 & 43 \\
\hline 30 & 31 & & & & 1105 & 1058 & 24 \\
\hline 33 & 36 & \multirow{2}{*}{7485,64} & \multirow{2}{*}{58,31} & \multirow{2}{*}{3,202} & 1140 & 1048 & 46 \\
\hline 34 & 35 & & & & 1096 & 1055 & 21 \\
\hline 37 & 40 & \multirow{2}{*}{7857,52} & \multirow{2}{*}{61,09} & \multirow{2}{*}{3,593} & 1139 & 1041 & 49 \\
\hline 38 & 39 & & & & 1088 & 1049 & 20 \\
\hline
\end{tabular}

Tabela I.9 - Resultados do modelo 5d.

\begin{tabular}{|c|c|c|c|c|c|c|c|}
\hline \multirow{2}{*}{\multicolumn{2}{|c|}{ Cabo }} & $\mathrm{P}$ & Ap & Peso & $\sigma_{\text {máx }}$ & $\sigma_{\text {mín }}$ & $\Delta \sigma$ \\
\hline & & $(\mathrm{kN})$ & $\left(\mathrm{cm}^{2}\right)$ & (Ton) & (MPa) & (MPa) & (MPa) \\
\hline 1 & 4 & \multirow{2}{*}{8551,03} & \multirow{2}{*}{80,14} & \multirow{2}{*}{1,948} & 1124 & 1066 & 29 \\
\hline 2 & 3 & & & & 1139 & 1070 & 35 \\
\hline 5 & 8 & \multirow{2}{*}{4226,20} & \multirow{2}{*}{39,42} & \multirow{2}{*}{1,105} & 1129 & 1070 & 30 \\
\hline 6 & 7 & & & & 1140 & 1073 & 34 \\
\hline 9 & 12 & \multirow{2}{*}{4794,98} & \multirow{2}{*}{44,48} & \multirow{2}{*}{1,414} & 1134 & 1075 & 30 \\
\hline 10 & 11 & & & & 1139 & 1076 & 32 \\
\hline 13 & 16 & \multirow{2}{*}{5313,98} & \multirow{2}{*}{48,98} & \multirow{2}{*}{1,744} & 1138 & 1079 & 30 \\
\hline 14 & 15 & & & & 1139 & 1079 & 30 \\
\hline 17 & 20 & \multirow{2}{*}{5798,00} & \multirow{2}{*}{53,39} & \multirow{2}{*}{2,106} & 1141 & 1077 & 32 \\
\hline 18 & 19 & & & & 1134 & 1079 & 28 \\
\hline 21 & 24 & \multirow{2}{*}{6253,90} & \multirow{2}{*}{57,64} & \multirow{2}{*}{2,495} & 1140 & 1071 & 35 \\
\hline 22 & 23 & & & & 1125 & 1075 & 25 \\
\hline 25 & 28 & \multirow{2}{*}{6685,55} & \multirow{2}{*}{61,67} & \multirow{2}{*}{2,908} & 1141 & 1067 & 37 \\
\hline 26 & 27 & & & & 1118 & 1073 & 23 \\
\hline 29 & 32 & \multirow{2}{*}{7095,50} & \multirow{2}{*}{65,58} & \multirow{2}{*}{3,346} & 1140 & 1062 & 39 \\
\hline 30 & 31 & & & & 1109 & 1069 & 20 \\
\hline 33 & 36 & \multirow{2}{*}{7485,64} & \multirow{2}{*}{69,31} & \multirow{2}{*}{3,806} & 1139 & 1058 & 41 \\
\hline 34 & 35 & & & & 1100 & 1066 & 17 \\
\hline 37 & 40 & \multirow{2}{*}{7857,52} & \multirow{2}{*}{72,57} & \multirow{2}{*}{4,279} & 1140 & 1056 & 42 \\
\hline 38 & 39 & & & & 1093 & 1065 & 14 \\
\hline
\end{tabular}


Tabela I.10 - Resultados do modelo 5e.

\begin{tabular}{|c|c|c|c|c|c|c|c|}
\hline \multirow{2}{*}{\multicolumn{2}{|c|}{ Cabo }} & $\mathrm{P}$ & Ap & Peso & $\sigma_{\text {máx }}$ & $\sigma_{\text {mín }}$ & $\Delta \sigma$ \\
\hline & & $(\mathrm{kN})$ & $\left(\mathrm{cm}^{2}\right)$ & (Ton) & (MPa) & (MPa) & (MPa) \\
\hline 1 & 4 & \multirow{2}{*}{8551,03} & \multirow{2}{*}{80,14} & \multirow{2}{*}{1,948} & 1125 & 1066 & 30 \\
\hline 2 & 3 & & & & 1139 & 1070 & 35 \\
\hline 5 & 8 & \multirow{2}{*}{4226,20} & \multirow{2}{*}{39,42} & \multirow{2}{*}{1,105} & 1130 & 1070 & 30 \\
\hline 6 & 7 & & & & 1140 & 1072 & 34 \\
\hline 9 & 12 & \multirow{2}{*}{4794,98} & \multirow{2}{*}{44,48} & \multirow{2}{*}{1,414} & 1134 & 1074 & 30 \\
\hline 10 & 11 & & & & 1140 & 1076 & 32 \\
\hline 13 & 16 & \multirow{2}{*}{5313,98} & \multirow{2}{*}{48,98} & \multirow{2}{*}{1,744} & 1138 & 1079 & 30 \\
\hline 14 & 15 & & & & 1139 & 1079 & 30 \\
\hline 17 & 20 & \multirow{2}{*}{5798,00} & \multirow{2}{*}{53,39} & \multirow{2}{*}{2,106} & 1141 & 1077 & 32 \\
\hline 18 & 19 & & & & 1134 & 1079 & 28 \\
\hline 21 & 24 & \multirow{2}{*}{6253,90} & \multirow{2}{*}{57,64} & \multirow{2}{*}{2,495} & 1140 & 1071 & 35 \\
\hline 22 & 23 & & & & 1125 & 1075 & 25 \\
\hline 25 & 28 & \multirow{2}{*}{6685,55} & \multirow{2}{*}{61,67} & \multirow{2}{*}{2,908} & 1141 & 1067 & 37 \\
\hline 26 & 27 & & & & 1118 & 1073 & 23 \\
\hline 29 & 32 & \multirow{2}{*}{7095,50} & \multirow{2}{*}{65,58} & \multirow{2}{*}{3,346} & 1141 & 1062 & 40 \\
\hline 30 & 31 & & & & 1109 & 1069 & 20 \\
\hline 33 & 36 & \multirow{2}{*}{7485,64} & \multirow{2}{*}{69,31} & \multirow{2}{*}{3,806} & 1140 & 1057 & 42 \\
\hline 34 & 35 & & & & 1100 & 1066 & 17 \\
\hline 37 & 40 & \multirow{2}{*}{7857,52} & \multirow{2}{*}{72,57} & \multirow{2}{*}{4,279} & 1141 & 1055 & 43 \\
\hline 38 & 39 & & & & 1093 & 1064 & 15 \\
\hline
\end{tabular}

Tabela I.11 - Resultados do modelo 5f.

\begin{tabular}{|c|c|c|c|c|c|c|c|}
\hline \multirow{2}{*}{\multicolumn{2}{|c|}{ Cabo }} & $\mathrm{P}$ & Ap & Peso & $\sigma_{\text {máx }}$ & $\sigma_{\text {mín }}$ & $\Delta \sigma$ \\
\hline & & $(\mathrm{kN})$ & $\left(\mathrm{cm}^{2}\right)$ & (Ton) & (MPa) & (MPa) & $(\mathrm{MPa})$ \\
\hline 1 & 4 & \multirow{2}{*}{8551,03} & \multirow{2}{*}{80,22} & \multirow{2}{*}{1,950} & 1129 & 1067 & 31 \\
\hline 2 & 3 & & & & 1140 & 1068 & 36 \\
\hline 5 & 8 & \multirow{2}{*}{4226,20} & \multirow{2}{*}{39,50} & \multirow{2}{*}{1,107} & 1131 & 1069 & 31 \\
\hline 6 & 7 & & & & 1140 & 1070 & 35 \\
\hline 9 & 12 & \multirow{2}{*}{4794,98} & \multirow{2}{*}{44,56} & \multirow{2}{*}{1,417} & 1135 & 1073 & 31 \\
\hline 10 & 11 & & & & 1140 & 1073 & 34 \\
\hline 13 & 16 & \multirow{2}{*}{5313,98} & \multirow{2}{*}{49,02} & \multirow{2}{*}{1,745} & 1140 & 1078 & 31 \\
\hline 14 & 15 & & & & 1141 & 1079 & 31 \\
\hline 17 & 20 & \multirow{2}{*}{5798,00} & \multirow{2}{*}{53,39} & \multirow{2}{*}{2,106} & 1140 & 1078 & 31 \\
\hline 18 & 19 & & & & 1136 & 1078 & 29 \\
\hline 21 & 24 & \multirow{2}{*}{6253,90} & \multirow{2}{*}{57,64} & \multirow{2}{*}{2,495} & 1139 & 1071 & 34 \\
\hline 22 & 23 & & & & 1128 & 1074 & 27 \\
\hline 25 & 28 & \multirow{2}{*}{6685,55} & \multirow{2}{*}{61,67} & \multirow{2}{*}{2,908} & 1140 & 1066 & 37 \\
\hline 26 & 27 & & & & 1121 & 1073 & 24 \\
\hline 29 & 32 & \multirow{2}{*}{7095,50} & \multirow{2}{*}{65,58} & \multirow{2}{*}{3,346} & 1139 & 1059 & 40 \\
\hline 30 & 31 & & & & 1112 & 1069 & 22 \\
\hline 33 & 36 & \multirow{2}{*}{7485,64} & \multirow{2}{*}{69,25} & \multirow{2}{*}{3,803} & 1139 & 1053 & 43 \\
\hline 34 & 35 & & & & 1103 & 1066 & 19 \\
\hline 37 & 40 & \multirow{2}{*}{7857,52} & \multirow{2}{*}{72,75} & \multirow{2}{*}{4,279} & 1139 & 1049 & 45 \\
\hline 38 & 39 & & & & 1096 & 1065 & 16 \\
\hline
\end{tabular}


Tabela I.12 - Resultados do modelo 5g.

\begin{tabular}{|c|c|c|c|c|c|c|c|}
\hline \multirow{2}{*}{\multicolumn{2}{|c|}{ Cabo }} & $\mathrm{P}$ & Ap & Peso & $\sigma_{\text {máx }}$ & $\sigma_{\text {mín }}$ & $\Delta \sigma$ \\
\hline & & $(\mathrm{kN})$ & $\left(\mathrm{cm}^{2}\right)$ & (Ton) & (MPa) & (MPa) & (MPa) \\
\hline 1 & 4 & \multirow{2}{*}{8551,03} & \multirow{2}{*}{80,82} & \multirow{2}{*}{1,965} & 1140 & 1071 & 35 \\
\hline 2 & 3 & & & & 1138 & 1060 & 39 \\
\hline 5 & 8 & \multirow{2}{*}{4226,20} & \multirow{2}{*}{39,79} & \multirow{2}{*}{1,115} & 1141 & 1070 & 36 \\
\hline 6 & 7 & & & & 1139 & 1063 & 38 \\
\hline 9 & 12 & \multirow{2}{*}{4794,98} & \multirow{2}{*}{44,98} & \multirow{2}{*}{1,430} & 1140 & 1070 & 35 \\
\hline 10 & 11 & & & & 1139 & 1065 & 37 \\
\hline 13 & 16 & \multirow{2}{*}{5313,98} & \multirow{2}{*}{49,57} & \multirow{2}{*}{1,765} & 1140 & 1071 & 35 \\
\hline 14 & 15 & & & & 1140 & 1070 & 35 \\
\hline 17 & 20 & \multirow{2}{*}{5798,00} & \multirow{2}{*}{53,78} & \multirow{2}{*}{2,121} & 1140 & 1072 & 34 \\
\hline 18 & 19 & & & & 1140 & 1075 & 33 \\
\hline 21 & 24 & \multirow{2}{*}{6253,90} & \multirow{2}{*}{57,64} & \multirow{2}{*}{2,495} & 1140 & 1074 & 33 \\
\hline 22 & 23 & & & & 1140 & 1080 & 30 \\
\hline 25 & 28 & \multirow{2}{*}{6685,55} & \multirow{2}{*}{61,56} & \multirow{2}{*}{2,903} & 1140 & 1067 & 37 \\
\hline 26 & 27 & & & & 1137 & 1082 & 28 \\
\hline 29 & 32 & \multirow{2}{*}{7095,50} & \multirow{2}{*}{65,28} & \multirow{2}{*}{3,331} & 1139 & 1058 & 41 \\
\hline 30 & 31 & & & & 1131 & 1082 & 25 \\
\hline 33 & 36 & \multirow{2}{*}{7485,64} & \multirow{2}{*}{68,74} & \multirow{2}{*}{3,775} & 1139 & 1051 & 44 \\
\hline 34 & 35 & & & & 1128 & 1084 & 22 \\
\hline 37 & 40 & \multirow{2}{*}{7857,52} & \multirow{2}{*}{72,09} & \multirow{2}{*}{4,239} & 1139 & 1044 & 48 \\
\hline 38 & 39 & & & & 1127 & 1083 & 22 \\
\hline
\end{tabular}

Tabela I.13 - Resultados do modelo 6a.

\begin{tabular}{|c|c|c|c|c|c|c|c|}
\hline \multirow{2}{*}{\multicolumn{2}{|c|}{ Cabo }} & $\mathrm{P}$ & Ap & Peso & $\sigma_{\text {máx }}$ & $\sigma_{\text {mín }}$ & $\Delta \sigma$ \\
\hline & & $(\mathrm{kN})$ & $\left(\mathrm{cm}^{2}\right)$ & (Ton) & (MPa) & (MPa) & (MPa) \\
\hline 1 & 4 & \multirow{2}{*}{9457,04} & \multirow{2}{*}{85,35} & \multirow{2}{*}{2,093} & 1136 & 1099 & 19 \\
\hline 2 & 3 & & & & 1140 & 1097 & 22 \\
\hline 5 & 8 & \multirow{2}{*}{4721,17} & \multirow{2}{*}{42,57} & \multirow{2}{*}{1,201} & 1138 & 1099 & 20 \\
\hline 6 & 7 & & & & 1140 & 1098 & 21 \\
\hline 9 & 12 & \multirow{2}{*}{5353,10} & \multirow{2}{*}{48,14} & \multirow{2}{*}{1,539} & 1138 & 1100 & 19 \\
\hline 10 & 11 & & & & 1140 & 1099 & 21 \\
\hline 13 & 16 & \multirow{2}{*}{5931,80} & \multirow{2}{*}{53,20} & \multirow{2}{*}{1,903} & 1140 & 1102 & 19 \\
\hline 14 & 15 & & & & 1140 & 1102 & 19 \\
\hline 17 & 20 & \multirow{2}{*}{6473,21} & \multirow{2}{*}{57,90} & \multirow{2}{*}{2,292} & 1140 & 1103 & 19 \\
\hline 18 & 19 & & & & 1139 & 1103 & 18 \\
\hline 21 & 24 & \multirow{2}{*}{6984,61} & \multirow{2}{*}{62,47} & \multirow{2}{*}{2,713} & 1139 & 1100 & 20 \\
\hline 22 & 23 & & & & 1135 & 1103 & 16 \\
\hline 25 & 28 & \multirow{2}{*}{7470,04} & \multirow{2}{*}{66,82} & \multirow{2}{*}{3,159} & 1139 & 1097 & 21 \\
\hline 26 & 27 & & & & 1132 & 1102 & 15 \\
\hline 29 & 32 & \multirow{2}{*}{7932,14} & \multirow{2}{*}{70,95} & \multirow{2}{*}{3,629} & 1140 & 1093 & 24 \\
\hline 30 & 31 & & & & 1128 & 1102 & 13 \\
\hline 33 & 36 & \multirow{2}{*}{8372,87} & \multirow{2}{*}{74,89} & \multirow{2}{*}{4,121} & 1140 & 1090 & 25 \\
\hline 34 & 35 & & & & 1125 & 1102 & 12 \\
\hline 37 & 40 & \multirow{2}{*}{8793,82} & \multirow{2}{*}{78,66} & \multirow{2}{*}{4,634} & 1140 & 1088 & 26 \\
\hline 38 & 39 & & & & 1122 & 1102 & 10 \\
\hline
\end{tabular}


Tabela I.14 - Resultados do modelo 6b.

\begin{tabular}{|c|c|c|c|c|c|c|c|}
\hline \multirow{2}{*}{\multicolumn{2}{|c|}{ Cabo }} & $\mathrm{P}$ & Ap & Peso & $\sigma_{\text {máx }}$ & $\sigma_{\text {mín }}$ & $\Delta \sigma$ \\
\hline & & $(\mathrm{kN})$ & $\left(\mathrm{cm}^{2}\right)$ & (Ton) & (MPa) & (MPa) & (MPa) \\
\hline 1 & 4 & \multirow{2}{*}{9457,04} & \multirow{2}{*}{114,91} & \multirow{2}{*}{2,818} & 850 & 815 & 18 \\
\hline 2 & 3 & & & & 854 & 813 & 21 \\
\hline 5 & 8 & \multirow{2}{*}{4721,17} & \multirow{2}{*}{57,23} & \multirow{2}{*}{1,615} & 851 & 816 & 18 \\
\hline 6 & 7 & & & & 854 & 814 & 20 \\
\hline 9 & 12 & \multirow{2}{*}{5353,10} & \multirow{2}{*}{64,73} & \multirow{2}{*}{2,069} & 852 & 816 & 18 \\
\hline 10 & 11 & & & & 854 & 815 & 20 \\
\hline 13 & 16 & \multirow{2}{*}{5931,80} & \multirow{2}{*}{71,38} & \multirow{2}{*}{2,553} & 854 & 818 & 18 \\
\hline 14 & 15 & & & & 855 & 818 & 19 \\
\hline 17 & 20 & \multirow{2}{*}{6473,21} & \multirow{2}{*}{77,71} & \multirow{2}{*}{3,076} & 854 & 819 & 18 \\
\hline 18 & 19 & & & & 853 & 819 & 17 \\
\hline 21 & 24 & \multirow{2}{*}{6984,61} & \multirow{2}{*}{83,65} & \multirow{2}{*}{3,632} & 854 & 819 & 18 \\
\hline 22 & 23 & & & & 852 & 821 & 16 \\
\hline 25 & 28 & \multirow{2}{*}{7470,04} & \multirow{2}{*}{89,57} & \multirow{2}{*}{4,235} & 854 & 815 & 20 \\
\hline 26 & 27 & & & & 848 & 820 & 14 \\
\hline 29 & 32 & \multirow{2}{*}{7932,14} & \multirow{2}{*}{95,11} & \multirow{2}{*}{4,865} & 855 & 812 & 22 \\
\hline 30 & 31 & & & & 845 & 820 & 13 \\
\hline 33 & 36 & \multirow{2}{*}{8372,87} & \multirow{2}{*}{100,39} & \multirow{2}{*}{5,525} & 855 & 809 & 23 \\
\hline 34 & 35 & & & & 842 & 819 & 12 \\
\hline 37 & 40 & \multirow{2}{*}{8793,82} & \multirow{2}{*}{105,44} & \multirow{2}{*}{6,213} & 855 & 806 & 25 \\
\hline 38 & 39 & & & & 838 & 819 & 10 \\
\hline
\end{tabular}

Tabela I.15 - Resultados do modelo 7a.

\begin{tabular}{|c|c|c|c|c|c|c|c|}
\hline \multirow{2}{*}{\multicolumn{2}{|c|}{ Cabo }} & $\mathrm{P}$ & Ap & Peso & $\sigma_{\text {máx }}$ & $\sigma_{\text {mín }}$ & $\Delta \sigma$ \\
\hline & & $(\mathrm{kN})$ & $\left(\mathrm{cm}^{2}\right)$ & (Ton) & (MPa) & (MPa) & (MPa) \\
\hline 1 & 4 & \multirow{2}{*}{4433,78} & \multirow{2}{*}{46,77} & \multirow{2}{*}{1,443} & 1133 & 1006 & 64 \\
\hline 2 & 3 & & & & 1141 & 984 & 79 \\
\hline 5 & 8 & \multirow{2}{*}{2085,16} & \multirow{2}{*}{22,18} & \multirow{2}{*}{0,753} & 1134 & 993 & 71 \\
\hline 6 & 7 & & & & 1141 & 974 & 84 \\
\hline 9 & 12 & \multirow{2}{*}{2322,07} & \multirow{2}{*}{24,70} & \multirow{2}{*}{0,920} & 1136 & 986 & 75 \\
\hline 10 & 11 & & & & 1141 & 971 & 85 \\
\hline 13 & 16 & \multirow{2}{*}{2544,47} & \multirow{2}{*}{26,95} & \multirow{2}{*}{1,095} & 1137 & 981 & 78 \\
\hline 14 & 15 & & & & 1140 & 972 & 84 \\
\hline 17 & 20 & \multirow{2}{*}{2759,27} & \multirow{2}{*}{28,92} & \multirow{2}{*}{1,275} & 1139 & 981 & 79 \\
\hline 18 & 19 & & & & 1141 & 978 & 82 \\
\hline 21 & 24 & \multirow{2}{*}{2968,92} & \multirow{2}{*}{30,89} & \multirow{2}{*}{1,472} & 1138 & 979 & 80 \\
\hline 22 & 23 & & & & 1136 & 983 & 77 \\
\hline 25 & 28 & \multirow{2}{*}{3174,33} & \multirow{2}{*}{32,83} & \multirow{2}{*}{1,682} & 1141 & 965 & 88 \\
\hline 26 & 27 & & & & 1129 & 985 & 72 \\
\hline 29 & 32 & \multirow{2}{*}{3375,79} & \multirow{2}{*}{35,09} & \multirow{2}{*}{1,927} & 1140 & 932 & 104 \\
\hline 30 & 31 & & & & 1108 & 977 & 66 \\
\hline 33 & 36 & \multirow{2}{*}{3573,43} & \multirow{2}{*}{37,22} & \multirow{2}{*}{2,181} & 1141 & 904 & 119 \\
\hline 34 & 35 & & & & 1090 & 973 & 59 \\
\hline 37 & 40 & \multirow{2}{*}{3767,26} & \multirow{2}{*}{39,32} & \multirow{2}{*}{2,450} & 1141 & 876 & 133 \\
\hline 38 & 39 & & & & 1077 & 963 & 57 \\
\hline
\end{tabular}


Tabela I.16 - Resultados do modelo 7b.

\begin{tabular}{|c|c|c|c|c|c|c|c|}
\hline \multirow{2}{*}{\multicolumn{2}{|c|}{ Cabo }} & $\mathrm{P}$ & Ap & Peso & $\sigma_{\text {máx }}$ & $\sigma_{\text {mín }}$ & $\Delta \sigma$ \\
\hline & & $(\mathrm{kN})$ & $\left(\mathrm{cm}^{2}\right)$ & (Ton) & (MPa) & (MPa) & (MPa) \\
\hline 1 & 4 & \multirow{2}{*}{4433,78} & \multirow{2}{*}{64,26} & \multirow{2}{*}{1,982} & 848 & 744 & 52 \\
\hline 2 & 3 & & & & 854 & 719 & 68 \\
\hline 5 & 8 & \multirow{2}{*}{2085,16} & \multirow{2}{*}{30,35} & \multirow{2}{*}{1,031} & 851 & 735 & 58 \\
\hline 6 & 7 & & & & 855 & 715 & 70 \\
\hline 9 & 12 & \multirow{2}{*}{2322,07} & \multirow{2}{*}{33,85} & \multirow{2}{*}{1,260} & 852 & 728 & 62 \\
\hline 10 & 11 & & & & 855 & 712 & 72 \\
\hline 13 & 16 & \multirow{2}{*}{2544,47} & \multirow{2}{*}{36,88} & \multirow{2}{*}{1,498} & 853 & 724 & 65 \\
\hline 14 & 15 & & & & 855 & 712 & 72 \\
\hline 17 & 20 & \multirow{2}{*}{2759,27} & \multirow{2}{*}{39,47} & \multirow{2}{*}{1,741} & 854 & 722 & 66 \\
\hline 18 & 19 & & & & 855 & 717 & 69 \\
\hline 21 & 24 & \multirow{2}{*}{2968,92} & \multirow{2}{*}{42,05} & \multirow{2}{*}{2,004} & 854 & 720 & 67 \\
\hline 22 & 23 & & & & 853 & 722 & 66 \\
\hline 25 & 28 & \multirow{2}{*}{3174,33} & \multirow{2}{*}{44,65} & \multirow{2}{*}{2,288} & 855 & 710 & 73 \\
\hline 26 & 27 & & & & 848 & 725 & 62 \\
\hline 29 & 32 & \multirow{2}{*}{3375,79} & \multirow{2}{*}{47,82} & \multirow{2}{*}{2,625} & 854 & 678 & 88 \\
\hline 30 & 31 & & & & 830 & 717 & 57 \\
\hline 33 & 36 & \multirow{2}{*}{3573,43} & \multirow{2}{*}{50,90} & \multirow{2}{*}{2,983} & 854 & 648 & 103 \\
\hline 34 & 35 & & & & 813 & 711 & 51 \\
\hline 37 & 40 & \multirow{2}{*}{3767,26} & \multirow{2}{*}{53,82} & \multirow{2}{*}{3,354} & 855 & 622 & 117 \\
\hline 38 & 39 & & & & 804 & 701 & 52 \\
\hline
\end{tabular}

Tabela I.17 - Resultados do modelo 8a.

\begin{tabular}{|c|c|c|c|c|c|c|c|}
\hline \multirow{2}{*}{\multicolumn{2}{|c|}{ Cabo }} & $\mathrm{P}$ & Ap & Peso & $\sigma_{\text {máx }}$ & $\sigma_{\text {mín }}$ & $\Delta \sigma$ \\
\hline & & $(\mathrm{kN})$ & $\left(\mathrm{cm}^{2}\right)$ & (Ton) & (MPa) & (MPa) & (MPa) \\
\hline 1 & 4 & \multirow{2}{*}{5145,26} & \multirow{2}{*}{49,57} & \multirow{2}{*}{1,547} & 1132 & 1061 & 36 \\
\hline 2 & 3 & & & & 1139 & 1052 & 44 \\
\hline 5 & 8 & \multirow{2}{*}{2461,92} & \multirow{2}{*}{23,88} & \multirow{2}{*}{0,819} & 1134 & 1054 & 40 \\
\hline 6 & 7 & & & & 1140 & 1047 & 47 \\
\hline 9 & 12 & \multirow{2}{*}{2735,73} & \multirow{2}{*}{26,53} & \multirow{2}{*}{0,996} & 1136 & 1051 & 43 \\
\hline 10 & 11 & & & & 1140 & 1046 & 47 \\
\hline 13 & 16 & \multirow{2}{*}{2993,30} & \multirow{2}{*}{28,98} & \multirow{2}{*}{1,185} & 1137 & 1050 & 44 \\
\hline 14 & 15 & & & & 1140 & 1047 & 47 \\
\hline 17 & 20 & \multirow{2}{*}{3242,52} & \multirow{2}{*}{31,21} & \multirow{2}{*}{1,384} & 1140 & 1052 & 44 \\
\hline 18 & 19 & & & & 1140 & 1052 & 44 \\
\hline 21 & 24 & \multirow{2}{*}{3486,15} & \multirow{2}{*}{33,42} & \multirow{2}{*}{1,601} & 1139 & 1051 & 44 \\
\hline 22 & 23 & & & & 1137 & 1054 & 42 \\
\hline 25 & 28 & \multirow{2}{*}{3725,15} & \multirow{2}{*}{35,72} & \multirow{2}{*}{1,839} & 1138 & 1038 & 50 \\
\hline 26 & 27 & & & & 1127 & 1050 & 39 \\
\hline 29 & 32 & \multirow{2}{*}{3959,84} & \multirow{2}{*}{38,00} & \multirow{2}{*}{2,095} & 1139 & 1026 & 57 \\
\hline 30 & 31 & & & & 1118 & 1048 & 35 \\
\hline 33 & 36 & \multirow{2}{*}{4190,30} & \multirow{2}{*}{40,25} & \multirow{2}{*}{2,367} & 1139 & 1014 & 63 \\
\hline 34 & 35 & & & & 1109 & 1047 & 31 \\
\hline 37 & 40 & \multirow{2}{*}{4416,55} & \multirow{2}{*}{42,39} & \multirow{2}{*}{2,650} & 1139 & 1003 & 68 \\
\hline 38 & 39 & & & & 1099 & 1045 & 27 \\
\hline
\end{tabular}


Tabela I.18 - Resultados do modelo 8b.

\begin{tabular}{|c|c|c|c|c|c|c|c|}
\hline \multirow{2}{*}{\multicolumn{2}{|c|}{ Cabo }} & $\mathrm{P}$ & Ap & Peso & $\sigma_{\text {máx }}$ & $\sigma_{\text {mín }}$ & $\Delta \sigma$ \\
\hline & & $(\mathrm{kN})$ & $\left(\mathrm{cm}^{2}\right)$ & (Ton) & (MPa) & (MPa) & (MPa) \\
\hline 1 & 4 & \multirow{2}{*}{5145,26} & \multirow{2}{*}{67,52} & \multirow{2}{*}{2,108} & 848 & 785 & 32 \\
\hline 2 & 3 & & & & 856 & 775 & 41 \\
\hline 5 & 8 & \multirow{2}{*}{2461,92} & \multirow{2}{*}{32,52} & \multirow{2}{*}{1,115} & 849 & 778 & 36 \\
\hline 6 & 7 & & & & 854 & 770 & 42 \\
\hline 9 & 12 & \multirow{2}{*}{2735,73} & \multirow{2}{*}{36,19} & \multirow{2}{*}{1,358} & 851 & 776 & 38 \\
\hline 10 & 11 & & & & 855 & 770 & 43 \\
\hline 13 & 16 & \multirow{2}{*}{2993,30} & \multirow{2}{*}{39,49} & \multirow{2}{*}{1,615} & 852 & 774 & 39 \\
\hline 14 & 15 & & & & 854 & 771 & 42 \\
\hline 17 & 20 & \multirow{2}{*}{3242,52} & \multirow{2}{*}{42,50} & \multirow{2}{*}{1,885} & 853 & 774 & 40 \\
\hline 18 & 19 & & & & 854 & 773 & 41 \\
\hline 21 & 24 & \multirow{2}{*}{3486,15} & \multirow{2}{*}{45,39} & \multirow{2}{*}{2,174} & 854 & 776 & 39 \\
\hline 22 & 23 & & & & 853 & 777 & 38 \\
\hline 25 & 28 & \multirow{2}{*}{3725,15} & \multirow{2}{*}{48,32} & \multirow{2}{*}{2,488} & 855 & 768 & 44 \\
\hline 26 & 27 & & & & 848 & 778 & 35 \\
\hline 29 & 32 & \multirow{2}{*}{3959,84} & \multirow{2}{*}{51,56} & \multirow{2}{*}{2,842} & 855 & 755 & 50 \\
\hline 30 & 31 & & & & 838 & 774 & 32 \\
\hline 33 & 36 & \multirow{2}{*}{4190,30} & \multirow{2}{*}{54,49} & \multirow{2}{*}{3,204} & 855 & 743 & 56 \\
\hline 34 & 35 & & & & 829 & 773 & 28 \\
\hline 37 & 40 & \multirow{2}{*}{4416,55} & \multirow{2}{*}{57,43} & \multirow{2}{*}{3,590} & 855 & 732 & 62 \\
\hline 38 & 39 & & & & 821 & 771 & 25 \\
\hline
\end{tabular}

Tabela I.19 - Resultados do modelo 9a.

\begin{tabular}{|c|c|c|c|c|c|c|c|}
\hline \multirow{2}{*}{\multicolumn{2}{|c|}{ Cabo }} & $\mathrm{P}$ & Ap & Peso & $\sigma_{\text {máx }}$ & $\sigma_{\text {mín }}$ & $\Delta \sigma$ \\
\hline & & $(\mathrm{kN})$ & $\left(\mathrm{cm}^{2}\right)$ & (Ton) & (MPa) & (MPa) & (MPa) \\
\hline 1 & 4 & \multirow{2}{*}{5843,03} & \multirow{2}{*}{53,80} & \multirow{2}{*}{1,698} & 1135 & 1092 & 22 \\
\hline 2 & 3 & & & & 1140 & 1088 & 26 \\
\hline 5 & 8 & \multirow{2}{*}{2821,68} & \multirow{2}{*}{26,08} & \multirow{2}{*}{0,903} & 1136 & 1089 & 24 \\
\hline 6 & 7 & & & & 1140 & 1085 & 28 \\
\hline 9 & 12 & \multirow{2}{*}{3130,26} & \multirow{2}{*}{28,98} & \multirow{2}{*}{1,097} & 1137 & 1086 & 26 \\
\hline 10 & 11 & & & & 1140 & 1084 & 28 \\
\hline 13 & 16 & \multirow{2}{*}{3420,91} & \multirow{2}{*}{31,62} & \multirow{2}{*}{1,302} & 1139 & 1087 & 26 \\
\hline 14 & 15 & & & & 1140 & 1086 & 27 \\
\hline 17 & 20 & \multirow{2}{*}{3702,50} & \multirow{2}{*}{34,16} & \multirow{2}{*}{1,524} & 1140 & 1087 & 27 \\
\hline 18 & 19 & & & & 1140 & 1087 & 27 \\
\hline 21 & 24 & \multirow{2}{*}{3978,10} & \multirow{2}{*}{36,60} & \multirow{2}{*}{1,762} & 1139 & 1087 & 26 \\
\hline 22 & 23 & & & & 1137 & 1088 & 25 \\
\hline 25 & 28 & \multirow{2}{*}{4248,76} & \multirow{2}{*}{39,12} & \multirow{2}{*}{2,023} & 1140 & 1081 & 30 \\
\hline 26 & 27 & & & & 1133 & 1087 & 23 \\
\hline 29 & 32 & \multirow{2}{*}{4514,81} & \multirow{2}{*}{41,57} & \multirow{2}{*}{2,301} & 1140 & 1074 & 33 \\
\hline 30 & 31 & & & & 1127 & 1086 & 21 \\
\hline 33 & 36 & \multirow{2}{*}{4776,31} & \multirow{2}{*}{43,98} & \multirow{2}{*}{2,595} & 1140 & 1068 & 36 \\
\hline 34 & 35 & & & & 1122 & 1085 & 19 \\
\hline 37 & 40 & \multirow{2}{*}{5033,24} & \multirow{2}{*}{46,35} & \multirow{2}{*}{2,906} & 1140 & 1062 & 39 \\
\hline 38 & 39 & & & & 1116 & 1085 & 16 \\
\hline
\end{tabular}


Tabela I.20 - Resultados do modelo 9b.

\begin{tabular}{|c|c|c|c|c|c|c|c|}
\hline \multirow{2}{*}{\multicolumn{2}{|c|}{ Cabo }} & $\mathrm{P}$ & Ap & Peso & $\sigma_{\text {máx }}$ & $\sigma_{\text {mín }}$ & $\Delta \sigma$ \\
\hline & & $(\mathrm{kN})$ & $\left(\mathrm{cm}^{2}\right)$ & (Ton) & (MPa) & (MPa) & (MPa) \\
\hline 1 & 4 & \multirow{2}{*}{5843,03} & \multirow{2}{*}{72,67} & \multirow{2}{*}{2,294} & 848 & 810 & 19 \\
\hline 2 & 3 & & & & 854 & 804 & 25 \\
\hline 5 & 8 & \multirow{2}{*}{2821,68} & \multirow{2}{*}{35,27} & \multirow{2}{*}{1,221} & 849 & 806 & 22 \\
\hline 6 & 7 & & & & 854 & 802 & 26 \\
\hline 9 & 12 & \multirow{2}{*}{3130,26} & \multirow{2}{*}{39,18} & \multirow{2}{*}{1,482} & 852 & 806 & 23 \\
\hline 10 & 11 & & & & 855 & 803 & 26 \\
\hline 13 & 16 & \multirow{2}{*}{3420,91} & \multirow{2}{*}{42,76} & \multirow{2}{*}{1,761} & 852 & 804 & 24 \\
\hline 14 & 15 & & & & 854 & 803 & 26 \\
\hline 17 & 20 & \multirow{2}{*}{3702,50} & \multirow{2}{*}{46,11} & \multirow{2}{*}{2,057} & 855 & 806 & 25 \\
\hline 18 & 19 & & & & 855 & 806 & 25 \\
\hline 21 & 24 & \multirow{2}{*}{3978,10} & \multirow{2}{*}{49,29} & \multirow{2}{*}{2,373} & 856 & 808 & 24 \\
\hline 22 & 23 & & & & 855 & 809 & 23 \\
\hline 25 & 28 & \multirow{2}{*}{4248,76} & \multirow{2}{*}{52,71} & \multirow{2}{*}{2,726} & 854 & 801 & 27 \\
\hline 26 & 27 & & & & 849 & 806 & 22 \\
\hline 29 & 32 & \multirow{2}{*}{4514,81} & \multirow{2}{*}{56,08} & \multirow{2}{*}{3,104} & 855 & 794 & 31 \\
\hline 30 & 31 & & & & 844 & 805 & 20 \\
\hline 33 & 36 & \multirow{2}{*}{4776,31} & \multirow{2}{*}{59,33} & \multirow{2}{*}{3,501} & 855 & 788 & 34 \\
\hline 34 & 35 & & & & 839 & 804 & 18 \\
\hline 37 & 40 & \multirow{2}{*}{5033,24} & \multirow{2}{*}{62,52} & \multirow{2}{*}{3,921} & 855 & 782 & 37 \\
\hline 38 & 39 & & & & 833 & 803 & 15 \\
\hline
\end{tabular}

Tabela I.21 - Resultados do modelo 10.

\begin{tabular}{|c|c|c|c|c|c|c|c|}
\hline \multirow{2}{*}{\multicolumn{2}{|c|}{ Cabo }} & $\mathrm{P}$ & Ap & Peso & $\sigma_{\text {máx }}$ & $\sigma_{\text {mín }}$ & $\Delta \sigma$ \\
\hline & & $(\mathrm{kN})$ & $\left(\mathrm{cm}^{2}\right)$ & (Ton) & (MPa) & (MPa) & (MPa) \\
\hline 1 & 4 & \multirow{2}{*}{12143,44} & \multirow{2}{*}{116,76} & \multirow{2}{*}{3,696} & 1136 & 1051 & 43 \\
\hline 2 & 3 & & & & 1139 & 1047 & 46 \\
\hline 5 & 8 & \multirow{2}{*}{4515,83} & \multirow{2}{*}{43,17} & \multirow{2}{*}{1,532} & 1138 & 1051 & 44 \\
\hline 6 & 7 & & & & 1139 & 1049 & 45 \\
\hline 9 & 12 & \multirow{2}{*}{5027,75} & \multirow{2}{*}{47,75} & \multirow{2}{*}{1,877} & 1141 & 1053 & 44 \\
\hline 10 & 11 & & & & 1140 & 1054 & 43 \\
\hline 13 & 16 & \multirow{2}{*}{5479,50} & \multirow{2}{*}{51,99} & \multirow{2}{*}{2,245} & 1142 & 1046 & 48 \\
\hline 14 & 15 & & & & 1134 & 1054 & 40 \\
\hline 17 & 20 & \multirow{2}{*}{5891,73} & \multirow{2}{*}{56,06} & \multirow{2}{*}{2,637} & 1141 & 1029 & 56 \\
\hline 18 & 19 & & & & 1122 & 1048 & 37 \\
\hline 21 & 24 & \multirow{2}{*}{6274,82} & \multirow{2}{*}{59,87} & \multirow{2}{*}{3,049} & 1139 & 1012 & 64 \\
\hline 22 & 23 & & & & 1110 & 1042 & 34 \\
\hline 25 & 28 & \multirow{2}{*}{6634,25} & \multirow{2}{*}{63,42} & \multirow{2}{*}{3,477} & 1139 & 998 & 71 \\
\hline 26 & 27 & & & & 1099 & 1039 & 30 \\
\hline 29 & 32 & \multirow{2}{*}{6972,70} & \multirow{2}{*}{66,66} & \multirow{2}{*}{3,914} & 1140 & 986 & 77 \\
\hline 30 & 31 & & & & 1097 & 1032 & 33 \\
\hline
\end{tabular}




\section{ANEXO II: MOMENTOS FLETORES NO TABULEIRO AO VARIAR A SUA ALTURA E A DA TORRE}

Este anexo tem por objetivo apresentar os momentos fletores no tabuleiro, devido ao carregamento permanente, e as envoltórias dos mesmos ao variar a altura da torre e a do tabuleiro.

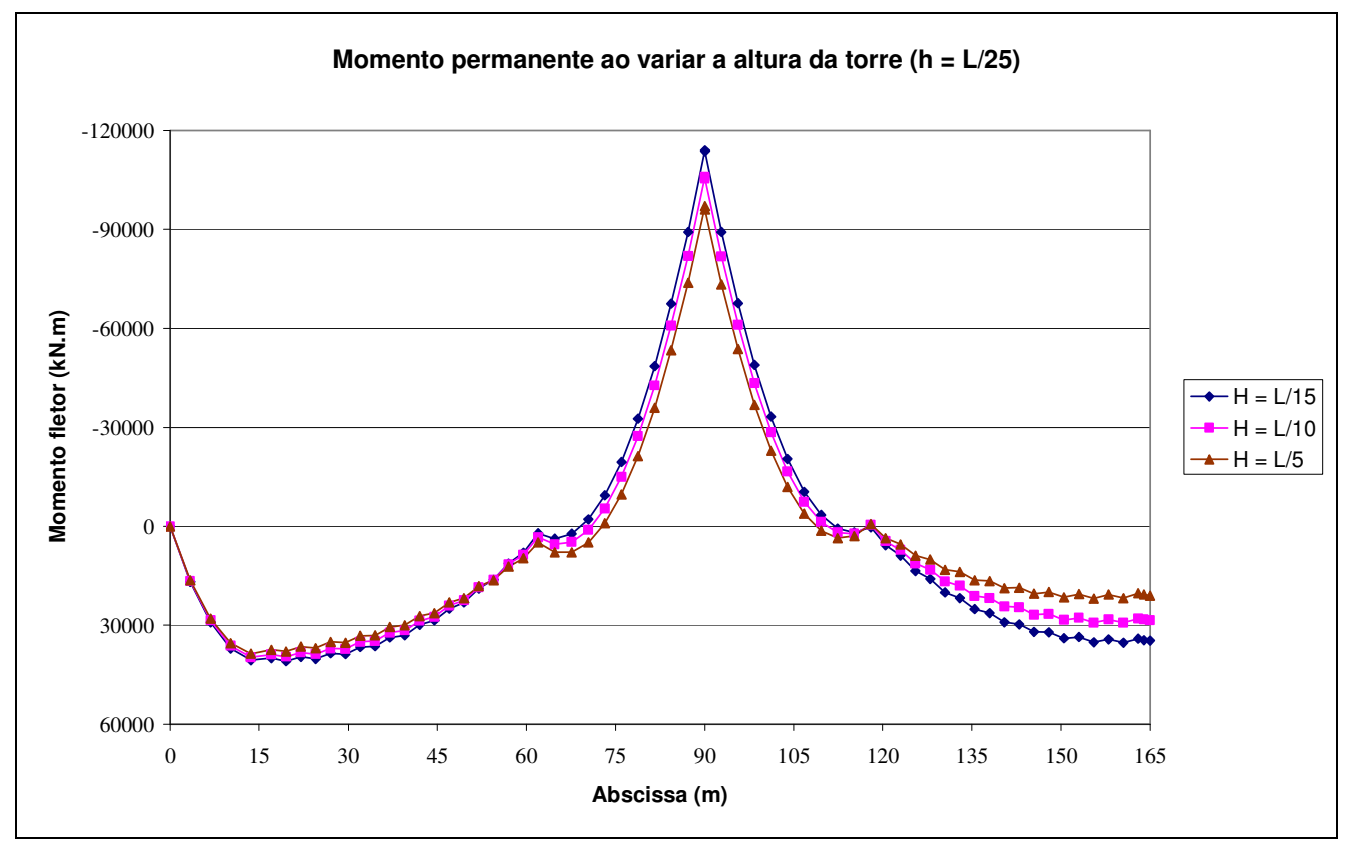



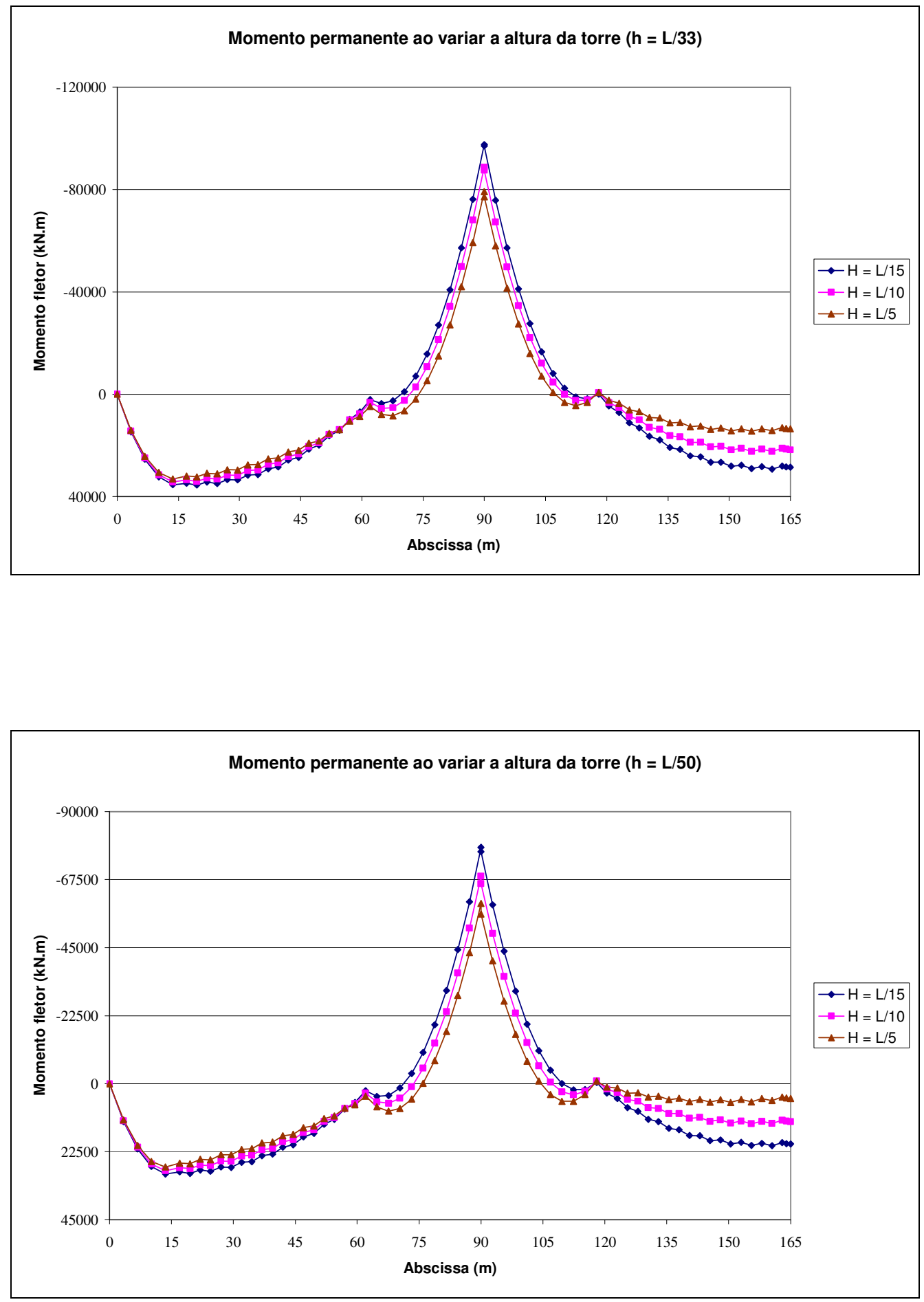

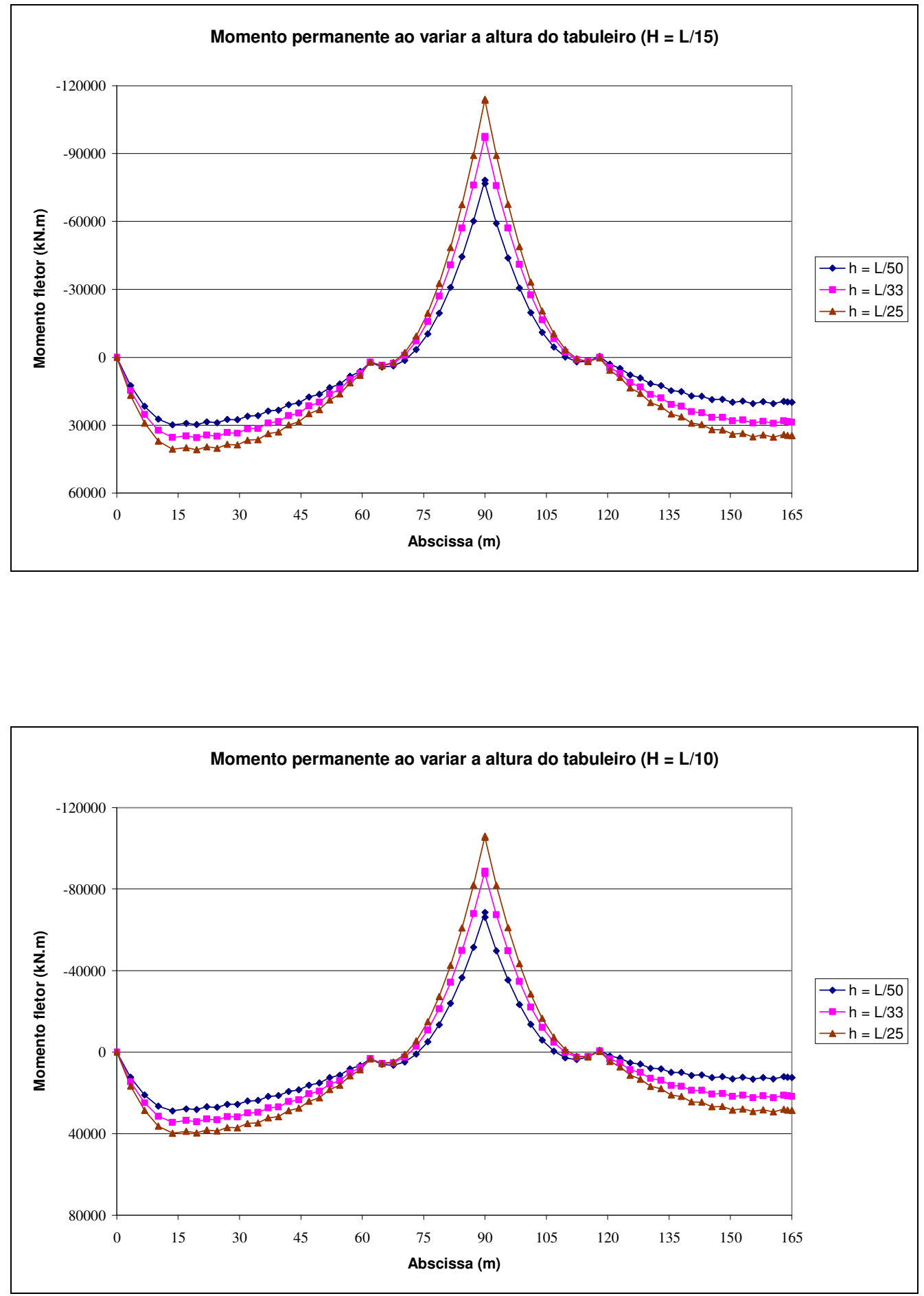

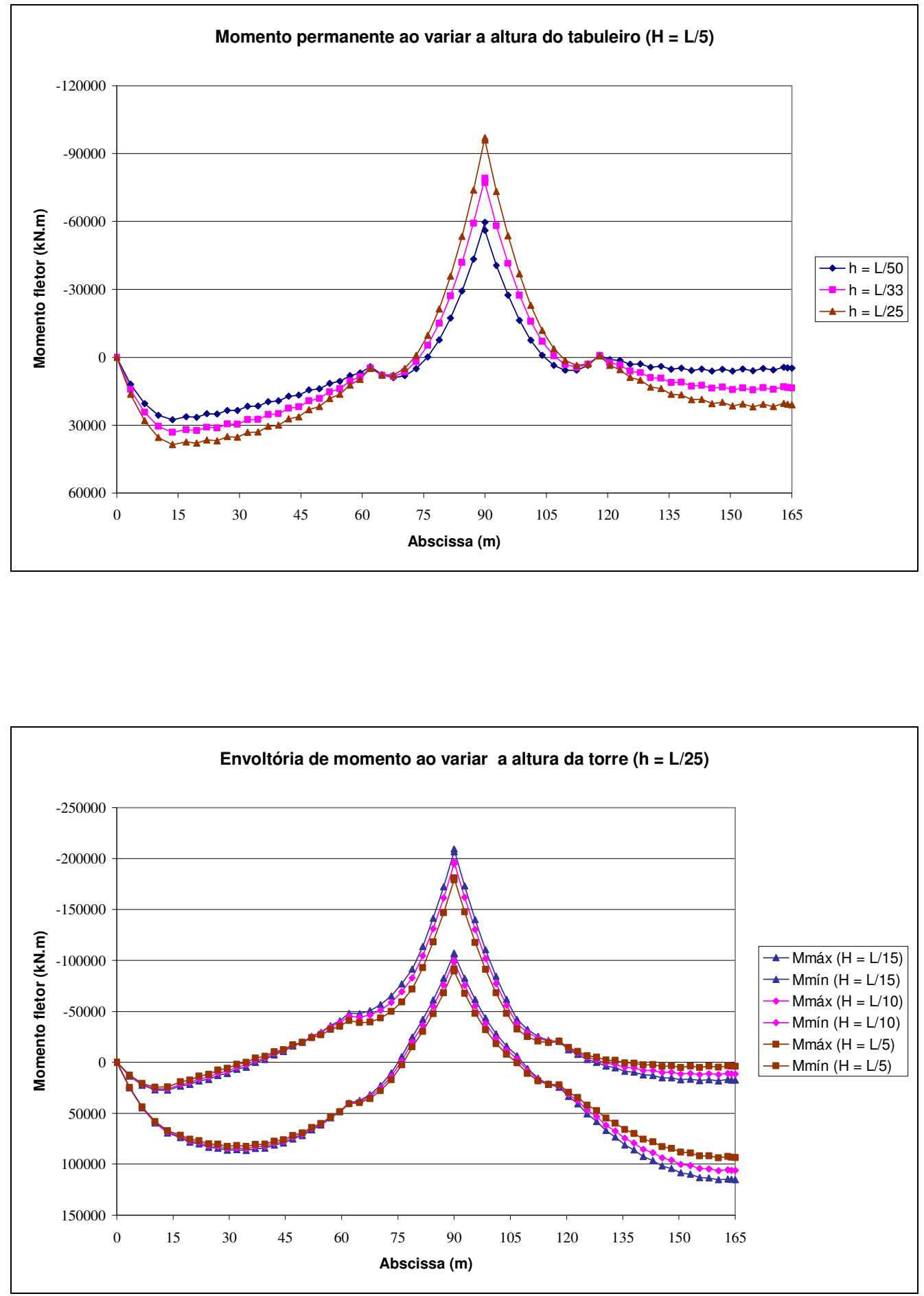

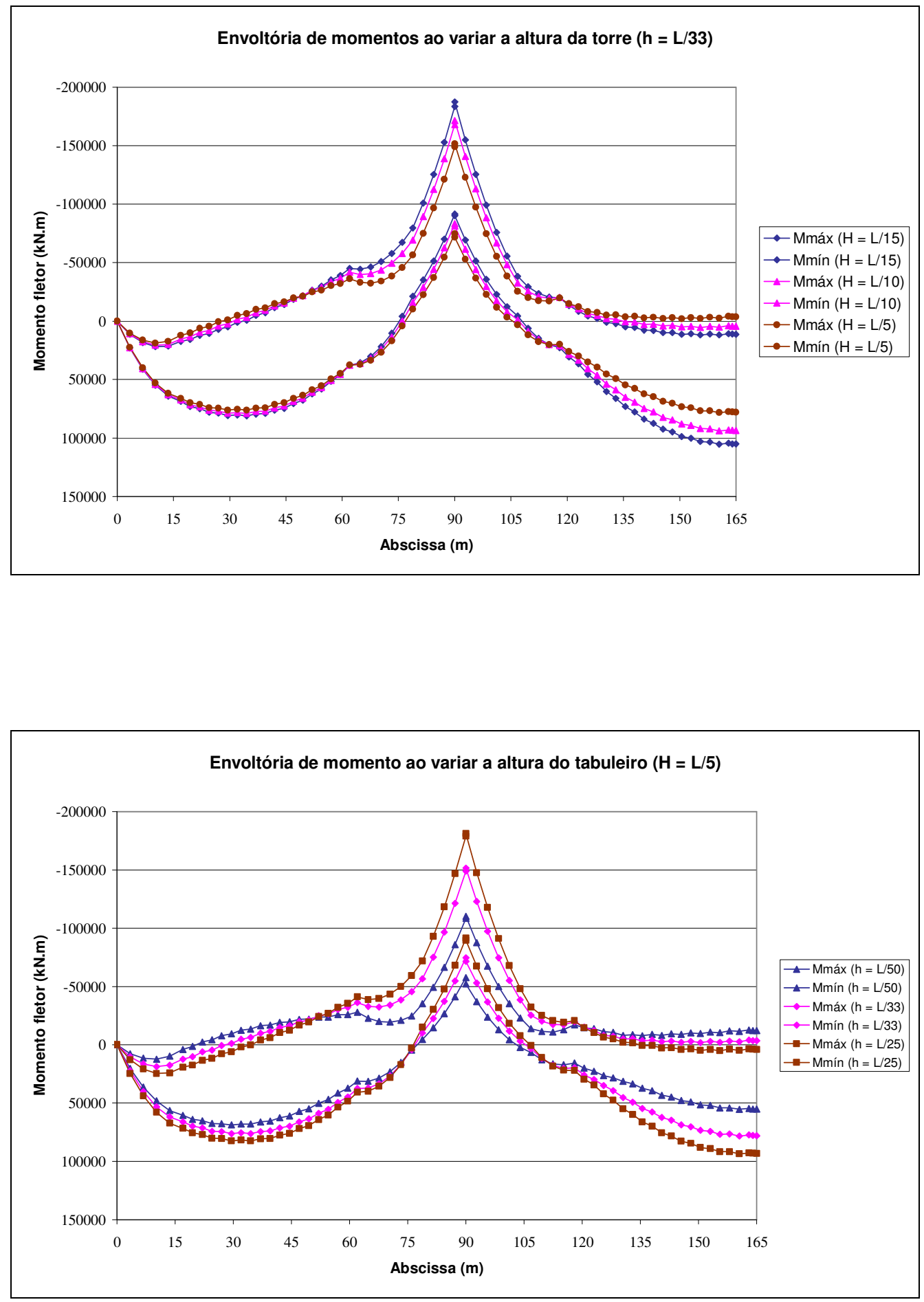


\section{ANEXO III: ALGUNS MODELOS COM ALTURA DE TABULEIRO VARIÁVEL}

Mostra-se, neste anexo, uma pequena análise parámetrica, com o intuito de recomendar as dimensões prévias de pontes com protensão no extradorso com altura de tabuleiro variável.

Os resultados mostrados a seguir indicam que a altura do tabuleiro no centro do vão tem que ser maior que L/40, mas como para a altura constante a recomendação de $h_{\text {mín }}$ é $L / 33$, não parece haver muita vantagem. No entanto, ressalta-se que os modelos aqui mostrados são poucos e não seguiram nenhum critério pré-definido, sendo necessário um estudo minucioso dos parâmetros deste tipo de estrutura.

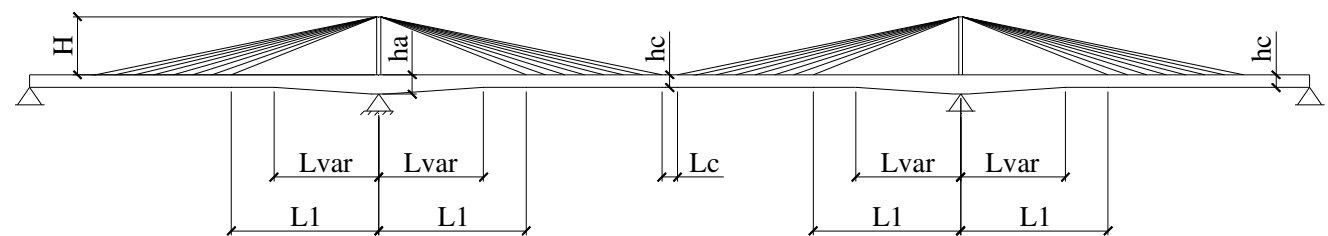

\begin{tabular}{|c|c|c|c|c|c|c|c|}
\hline Modelo & $\mathrm{H}$ & $\mathrm{h}_{\mathrm{a}}$ & $\mathrm{h}_{\mathrm{c}}$ & $\mathrm{L}_{\mathrm{var}}(\% \mathrm{~L})$ & $\mathrm{L}_{\mathrm{c}}(\mathrm{m})$ & $\mathrm{L}_{1}(\% \mathrm{~L})$ & $\Delta \sigma_{\text {máx }}(\mathrm{MPa})$ \\
\hline 10 & $\mathrm{~L} / 10$ & $\mathrm{~L} / 30$ & $\mathrm{~L} / 45$ & 18 & 4 & 25 & 77 \\
\hline $10 \mathrm{~b}$ & $\mathrm{~L} / 10$ & $\mathrm{~L} / 30$ & $\mathrm{~L} / 45$ & 18 & 4 & 18 & 78 \\
\hline $10 \mathrm{c}$ & $\mathrm{L} / 10$ & $\mathrm{~L} / 25$ & $\mathrm{~L} / 50$ & 18 & 4 & 25 & 88 \\
\hline $10 \mathrm{~d}$ & $\mathrm{~L} / 10$ & $\mathrm{~L} / 25$ & $\mathrm{~L} / 45$ & 18 & 4 & 25 & 75 \\
\hline $10 \mathrm{e}$ & $\mathrm{L} / 10$ & $\mathrm{~L} / 25$ & $\mathrm{~L} / 45$ & 24 & 4 & 24 & 71 \\
\hline $10 \mathrm{f}$ & $\mathrm{L} / 10$ & $\mathrm{~L} / 25$ & $\mathrm{~L} / 45$ & 18 & 24 & 24 & 75 \\
\hline $10 \mathrm{~g}$ & $\mathrm{~L} / 15$ & $\mathrm{~L} / 25$ & $\mathrm{~L} / 45$ & 18 & 4 & 25 & 62 \\
\hline $10 \mathrm{~h}$ & $\mathrm{~L} / 10$ & $\mathrm{~L} / 25$ & $\mathrm{~L} / 40$ & 24 & 4 & 28 & 72 \\
\hline
\end{tabular}

